\title{
Site U1313
}

\author{
Expedition 306 Scientists $^{2}$
}

\section{Chapter contents}

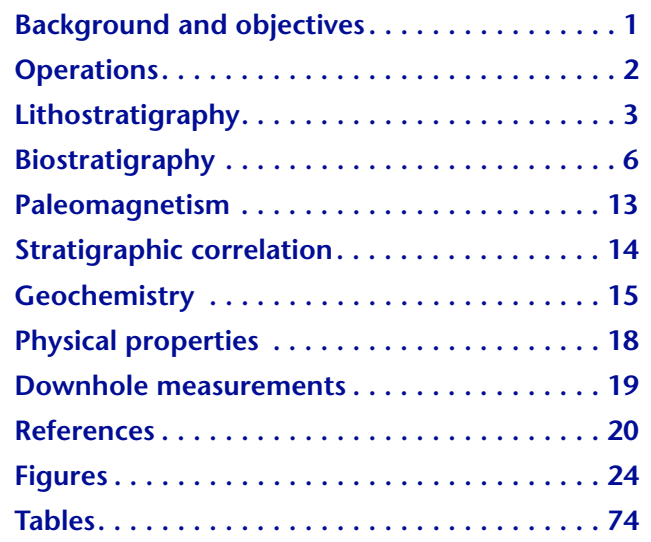

${ }^{1}$ Expedition 306 Scientists, 2006. Site U1313. In Channell, J.E.T., Kanamatsu, T., Sato, T., Stein, R., Alvarez Zarikian, C.A., Malone, M.J., and the Expedition 303/306 Scientists. Proc. IODP, 303/ 306: College Station TX (Integrated Ocean Drilling Program Management International, Inc.). doi:10.2204/iodp.proc.303306.112.2006 'Expedition 306 Scientists' addresses.

\section{Background and objectives}

Integrated Ocean Drilling Program Site U1313 constitutes a reoccupation of Deep Sea Drilling Project (DSDP) Site 607 located at the base of the upper western flank of the Mid-Atlantic Ridge in a water depth of $3426 \mathrm{~m}, \sim 240 \mathrm{mi}$ northwest of the Azores (Fig. F1). Seismic air gun profiles indicate a prevalent sediment cover of 500-900 $\mathrm{m}$ above the acoustic basement in this region (Fig. F2). Two holes were drilled at this site during Leg 94 (June-August 1983) using the variable-length hydraulic piston coring system and the extended core barrel system (Ruddiman, Kidd, Thomas, et al., 1987). Hole 607 penetrated to a total depth of $284.4 \mathrm{~m}$ and Hole $607 \mathrm{~A}$ to a total depth of $311.3 \mathrm{~m}$. The sediments recovered at Site 607 consist predominantly of calcareous biogenic oozes with variable amounts of fine-grained terrigenous material. The sedimentary sequence can be divided into two major lithologic units (Fig. F3). Unit I, from 0 to 116 meters below seafloor (mbsf) (late Pliocene-Pleistocene), is characterized by cyclically interlayered intervals of dark sediment rich in fine-grained terrigenous material (silty clay foraminiferal-nannofossil ooze) and lighter colored sediment with relatively small amounts of terrigenous compounds (mainly foraminiferal-nannofossil ooze). Unit II, below 116 mbsf (late Miocene-early late Pliocene), is composed of pale gray to white foraminiferal-nannofossil ooze and nannofossil ooze. Based on magneto- and biostratigraphy, the mean sedimentation rate at Site 607 is $\sim 5 \mathrm{~cm} / \mathrm{k}$.y. for the Pliocene-Pleistocene time interval (Baldauf et al., 1987).

The rationale for reoccupying this site is essentially the same as that for Site U1308 (recoring of Site 609; see the "Site U1308" chapter). Together, Sites 607 and 609 constitute benchmark sites for the long-term (millions of years) as well as short-term surface and deep ocean climate records from the subpolar North Atlantic. Site 607, situated under the influence of North Atlantic Deep Water (NADW) (Fig. F4), has been very important for generating benthic $\delta^{18} \mathrm{O}, \delta^{13} \mathrm{C}$, and $\mathrm{CaCO}_{3}$ records for the Pleistocene (Ruddiman et al., 1989) and late Pliocene (Ruddiman et al., 1986; Raymo et al., 1989, 2004) (Fig. F3) and for interpreting these records in terms of ice sheet variability and changes in NADW circulation, as well as for generating orbitally tuned timescales. Site 607, at a water depth of $3427 \mathrm{~m}$, remains the only site in the high-latitude North Atlantic that monitors NADW circulation throughout the Pleistocene. Leg 94 drilling of this site preceded the advent of the 
shipboard capability for construction of composite sections and pass-through magnetometers for continuous measurement of magnetic parameters. Paleomagnetic data from this site indicate that the magnetic properties are optimal for recording the geomagnetic field. The present condition of existing DSDP cores collected in 1983 does not permit the high-resolution studies proposed here.

At the site of Core VM 30-97, located close to Site 607 , Heinrich events are marked by a distinctive detrital carbonate signature, providing a means of correlation to other Expedition 303 and 306 sites. Based on census counts of planktonic foraminifers, sea-surface temperature (SST) warmed markedly during the Heinrich events and during the Last Glacial Maximum (LGM; 18 and $20 \mathrm{ka}$ ) in distinct contrast to the climate records from the subpolar North Atlantic (Bond et al., 1999b). This complex SST pattern, with respect to the subpolar North Atlantic, has now been traced from the early Holocene to Heinrich event 5 at $46 \mathrm{ka}$. Recent coupled ocean-atmosphere models suggest that during full shutdowns of NADW production, likely during Heinrich events, complex patterns of SST may appear globally (Schiller et al., 1997) with antiphased warm anomalies appearing south of Newfoundland (Manabe and Stouffer, 1999). Reconstruction of SSTs in the North Atlantic indicates that the Polar Front was situated between $\sim 42^{\circ}$ and $46^{\circ} \mathrm{N}$ during glacial times, extending in an east-west direction and resulting in a steep southnorth SST gradient (CLIMAP, 1976; Pflaumann et al., 2003) (Fig. F5A). Alkenone SST estimates determined in sediment cores from areas south of and within the Polar Front resulted in very different values for different glacials (Fig. F5B) (Calvo et al., 2001), indicating different climatic conditions (e.g., the location of the Polar Front) in these glacial periods.

Site U1313 (especially in combination with similar records from other Expedition 303 and 306 sites) will document the evolution of the complex surface temperature phasing over time, addressing questions such as whether the patterns are a peculiarity of the last glaciation, whether they were present in the 41 k.y. world, and whether they appeared at the onset of northern hemisphere glaciation. Antiphased patterns of ocean surface temperatures are documented in Core VM 30-97 for the 10-40 ka interval (Bond et al., 1999a). Redrilling Site 607 will provide a longterm record of this apparent antiphase pattern, which is now beginning to emerge in the western North Atlantic. By placing the surface temperature signals into a chronological framework based on a combination of oxygen isotopic stratigraphy, detrital carbonate-bearing Heinrich events, and geomagnetic paleointensity, we expect to obtain an optimal re- construction of the phasing of the temperature records and their relationship to ice sheet instability and changes in deepwater circulation.

\section{Operations}

We departed the Azores Islands for Site U1313 (proposed Site IRD3A) at $0645 \mathrm{~h}$ on Saturday, $26 \mathrm{March}$ 2005 , after spending 8 days in the lee of the islands during severe weather conditions. The $277 \mathrm{nmi}$ transit to Site U1313 began with sea-state conditions still somewhat marginal but expected to continuously improve over time. The transit was completed at an average speed of $8.9 \mathrm{kt}$, and we arrived at Site U1313 at $1425 \mathrm{~h}$ on Easter Sunday, 27 March. See Table T1 for a summary of coring at Site U1313.

\section{Hole U1313A}

Hole U1313A was spudded at $0005 \mathrm{~h}$ on 28 March 2005, establishing a rig floor-corrected seafloor depth of 3423.3 meters below rig floor (mbrf). Core $1 \mathrm{H}$ recovered $5.2 \mathrm{~m}$ of sediment, indicating a seafloor depth of 3412.3 meters below sea level. The advanced piston coring (APC) system, utilizing nonmagnetic core barrels, continued through Core $31 \mathrm{H}$. Alloy steel barrels were utilized for Cores $32 \mathrm{H}$ and $33 \mathrm{H}$, and drillover of stuck APC barrels was required for these last two cores. Tensor core orientation was used for all cores beginning with Core $3 \mathrm{H}$ from a depth of 14.7 mbsf. All core barrels fully stroked except for the last one, Core $33 \mathrm{H}$. The cored interval for this hole was $308.6 \mathrm{~m}$, and $319.64 \mathrm{~m}$ of sediment was recovered (recovery $=103.6 \%$ ). The drill string was pulled clear of the seafloor at $1300 \mathrm{~h}$ on 29 March, concluding operations in Hole U1313A.

\section{Hole U1313B}

Hole U1313B was offset $25 \mathrm{~m}$ due north $\left(000^{\circ}\right)$ from Hole U1313A and was spudded at $1430 \mathrm{~h}$ on 29 March 2005. The bit was positioned at a depth of $3421.0 \mathrm{mbrf}$, or $2.0 \mathrm{~m}$ deeper than Hole U1313A, and Core $1 \mathrm{H}$ recovered $5.90 \mathrm{~m}$ of sediment, establishing a rig floor-corrected seafloor depth of 3424.6 mbrf. APC coring continued through Core $20 \mathrm{H}$ to a depth of 186.4 mbsf. At that time, operations personnel were advised that the core breaks between Holes U1313A and U1313B were possibly becoming aligned. As a precaution to ensure adequate overlap between holes, the driller was advised to advance the bit $2.0 \mathrm{~m}$ further before shooting Core $21 \mathrm{H}$. Coring then continued until $1930 \mathrm{~h}$ on $30 \mathrm{March}$, through Core $32 \mathrm{H}$, to a total depth of 302.4 mbsf. Tensor core orientation was used for all cores beginning with Core $3 \mathrm{H}$ from a depth of 15.4 mbsf. All core barrels fully stroked, and no drillover was required in this 
hole. Nonmagnetic core barrels were used in the recovery of all 32 cores. The cored interval for this hole was $300.4 \mathrm{~m}$, and $306.54 \mathrm{~m}$ of sediment was recovered (recovery $=102.0 \%$ ).

After completing coring operations, Hole U1313B was prepared for logging. A wiper trip was conducted from total depth to 74.9 mbrf and back to total depth without difficulty. No fill, drag, or overpull was detected. The hole was swept with one final 30 bbl mud sweep, and the lockable float valve (LFV) go-devil was pumped down to lock open the LFV for the wireline logging tools. The hole was displaced with $140 \mathrm{bbl}$ of sepiolite mud, and the drill pipe was retracted to $80.7 \mathrm{mbsf}$. The triple combination (triple combo) tool string was deployed (including the General Purpose Inclinometer Tool and Multi-Sensor Spectral Gamma Ray Tool [MGT]) to within $2.0 \mathrm{~m}$ of the bottom of the hole. We successfully logged 220 $\mathrm{m}$ of the open hole and then the interval within the pipe to the seafloor. The scheduled deployment of the Formation MicroScanner (FMS)-sonic tool string was cancelled because the Lamont-Doherty Earth Observatory (LDEO) Logging Staff Scientist felt that the resistivity signal was too weak to make the deployment worthwhile. After recovery of the wireline tools, new software for the Schlumberger wireline heave-compensated logging winch was briefly tested. The software was tested for $\sim 45$ min under a variety of conditions, and the results appeared to be "very promising." The Schlumberger logging sheaves were rigged down, and the drill string was pulled clear of the seafloor at $1310 \mathrm{~h}$ on 31 March, ending Hole U1313B.

\section{Hole U1313C}

The drillship was offset $25 \mathrm{~m}$ due east $\left(90^{\circ}\right)$ of Hole U1313B. The bit was positioned at a depth of 3417.0 mbrf, $2.0 \mathrm{~m}$ shallower than for Hole U1313A. Hole U1313C was spudded at $1440 \mathrm{~h}$ on 31 March 2005. Core $1 \mathrm{H}$ recovered $2.71 \mathrm{~m}$ and established a rig floor-corrected seafloor depth of 3423.8 mbrf. APC coring with nonmagnetic core barrels continued through Core $30 \mathrm{H}$, and alloy steel barrels were used for the last two cores $(31 \mathrm{H}$ and $32 \mathrm{H})$. Tensor core orientation was used for all cores beginning with Core $4 \mathrm{H}$ from a depth of $21.7 \mathrm{mbsf}$. Drillover was required for recovery of Cores $29 \mathrm{H}$ through $32 \mathrm{H}$. All core barrels fully stroked except for the last three (Cores $30 \mathrm{H}$ through $32 \mathrm{H}$ ). The bit was advanced $8.73 \mathrm{~m}$ prior to shooting Core $32 \mathrm{H}$. The drill string was pulled clear of the seafloor at $2140 \mathrm{~h}$ on 1 April, officially ending Hole U1313C. The cored interval for this hole was $293.4 \mathrm{~m}$, and $305.79 \mathrm{~m}$ of sediment was recovered (recovery $=104.2 \%)$.

\section{Hole U1313D}

The drillship was offset $25 \mathrm{~m}$ due south $\left(180^{\circ}\right)$ of Hole U1313C. The bit was positioned at a depth of 3423.0 mbrf, or $4.0 \mathrm{~m}$ deeper than for Hole U1313A. Hole U1313D was spudded at $2255 \mathrm{~h}$ on 1 April 2005 . Core $1 \mathrm{H}$ was fully recovered $(9.80 \mathrm{~m})$; therefore, the seafloor depth of 3423.0 mbrf was considered suspect. A valid seafloor depth was not critical for this hole because good seafloor measurements had already been obtained on the three previous holes and the emphasis was to maximize recovery in Core $1 \mathrm{H}$. APC coring continued without incident in Hole U1313D through Core $16 \mathrm{H}$ to a total depth of 152.0 mbsf. Tensor core orientation was used for all cores, beginning with Core $3 \mathrm{H}$ from a depth of 19.0 mbsf. All core barrels fully stroked, and no drillover was required. Nonmagnetic core barrels were used for recovery of all 16 cores. The cored interval for this hole was $152.0 \mathrm{~m}$, and $159.27 \mathrm{~m}$ of sediment was recovered (recovery $=104.8 \%$ ).

The drill string was pulled clear of the seafloor at $1310 \mathrm{~h}$ on 2 April, and during the pipe trip positioning, beacon SN 2199 was recovered at $1430 \mathrm{~h}$. After we recovered and stored the drill string, the ship was secured for transit, all thrusters and hydrophones were pulled, and at $2030 \mathrm{~h}$, the ship was switched from dynamic positioning to cruise mode and got under way for alternate Site U1314 (proposed Site GAR1B).

\section{Lithostratigraphy}

At Site U1313, a $308 \mathrm{~m}$ sequence of pelagic sediment was recovered in four holes. The major sediment is composed of nannofossil ooze with varying amounts of foraminifers and clay- to silt-sized terrigenous material. Major lithologies range from silty clay nannofossil ooze to nannofossil ooze, with minor foraminifer nannofossil ooze, silty clay nannofossil ooze with diatoms, and nannofossil silty clay. Smear slides indicate that noncalcareous sediment contains biogenic silica, quartz, and clay and generally makes up $5 \%-40 \%$ of the sedimentary sequence (Fig. F6). Sediments recovered are generally undisturbed.

Lithologic units for the Site U1313 sedimentary sequence are defined on the basis of data obtained from smear slide examination, visual observation of sediment color, percent carbonate (see Fig. F27 in "Geochemistry"), lightness parameters of spectral reflectance measurements $\left(\mathrm{L}^{*}\right)$, and physical property data (see "Physical properties"). Two major lithologic units were identified. Unit I consists of Holocene-upper Pliocene alternating nannofossil ooze, silty clay nannofossil ooze, and nannofossil ooze with clay. Unit II extends to the total depth of 
each hole. It consists of upper Pliocene-uppermost Miocene nannofossil ooze. Unit I can be further divided into subunits on the basis of changes in the percentage of and variability in clay and nannofossil content. Figure F7 shows a summary of the lithologic units at Site U1313.

\section{Description of units}

\section{Unit I}

Intervals: Sections 306-U1313A-1H-1, $0 \mathrm{~cm}$, through 13H-2, $66 \mathrm{~cm}$; 306-U1312B-1H-1, 0 $\mathrm{cm}$, through $13 \mathrm{H}-1,88 \mathrm{~cm} ; 306-\mathrm{U} 1313 \mathrm{C}-1 \mathrm{H}-$ $1,0 \mathrm{~cm}$, through $13 \mathrm{H}-4,30 \mathrm{~cm}$; and $306-$ U1312D-1H-1, $0 \mathrm{~cm}$, through $12 \mathrm{H}-6,114 \mathrm{~cm}$

Depths: Hole U1313A: 0-111.86 mbsf, Hole U1313B: 0-111.28 mbsf, Hole U1313C: 0$112.00 \mathrm{mbsf}$, and Hole U1313D: 0-113.14 mbsf

Age: Holocene-late Pliocene

This unit represents deposition during the Holocene-late Pliocene. Dominant lithologies are silty clay nannofossil ooze, nannofossil ooze with clay, and nannofossil ooze, which are gray (5Y 6/1), light gray (5Y 7/1), and white (5Y $8 / 1$ and N9). The unit is defined by centimeter- to decimeter-scale variability in detrital clay and biogenic carbonate with decreased variability downcore. Lithologic variability occurs visually in the form of distinct cyclic color changes at centimeter to decimeter scale. This is reflected by large-amplitude shifts in carbonate content (Fig. F27), as well as large variability in gamma ray attenuation (GRA) density and magnetic susceptibility and intensity measurements (Figs. F18, F32, F35). Occasional millimeter- to centimeter-scale diffuse bands of green and gray (5G 7/2 and N4-N5) are distributed throughout the unit. Boundaries between intervals are often gradational and bioturbated. In general, bioturbation/mottling is rare to moderate, and burrows up to $2-3 \mathrm{~cm}$ in size are mainly located across contacts between contrasting colors. Dropstones frequently occur throughout Unit I (see below).

\section{Subunit IA}

Intervals: Sections 306-U1313A-1H-1, $0 \mathrm{~cm}$, through 5H-5, $130 \mathrm{~cm}$; 306-U1312B-1H-1, 0 $\mathrm{cm}$, through $5 \mathrm{H}-4,48 \mathrm{~cm} ; 306-\mathrm{U} 1313 \mathrm{C}-1 \mathrm{H}-$ $1,0 \mathrm{~cm}$, through $6 \mathrm{H}-1,38 \mathrm{~cm}$; and $306-$ $\mathrm{U} 1312 \mathrm{D}-1 \mathrm{H}-1,0 \mathrm{~cm}$, to $5 \mathrm{H}-2,20 \mathrm{~cm}$

Depths: Hole U1313A: 0-41.00 mbsf, Hole U1313B: 0-39.38 mbsf, Hole U1313C: 041.08 mbsf, and Hole U1313D: 0-39.7 mbsf

Age: Holocene-early Pleistocene
This subunit is characterized by the largest-scale amplitude fluctuations in detrital clay and biogenic carbonate in Unit I. This is reflected by distinct color changes and shifts in both $\mathrm{L}^{*}$ (Fig. F7), carbonate (Fig. F27), GRA density (Fig. F35), and magnetic susceptibility (Fig. F32). The uppermost $\sim 65 \mathrm{~cm}$ of the succession is yellowish brown (10Y 5/4) and consists of nannofossil silty clay. This interval represents the Holocene, and the color is related to sediment oxidation due to circulation of oxygen-rich seawater. The remainder of the subunit consists of nannofossil silty clay, silty clay nannofossil ooze, nannofossil ooze with clay, nannofossil ooze, and subordinate intervals of silty clay nannofossil ooze with diatoms and nannofossil ooze with diatoms and clay. Color varies from white (N9 and 5Y 8/1) to light gray (5Y 7/1) and gray (5Y 6/1) with subordinate light olive-gray (5Y $7 / 2$ ) and olive-gray (5Y 6/2). Color changes are usually gradational and bioturbated and reflect variation in carbonate versus clay content. In general, bioturbation is rare to moderate. Typical abundance of biogenic and terrigenous components, as estimated from smear slides, are nannofossils $(30 \%-$ $90 \%)$, clay $(0 \%-35 \%)$, detrital calcite $(0 \%-30 \%)$, detrital quartz $(0 \%-20 \%)$, diatoms $(1 \%-10 \%)$, foraminifers $(0 \%-10 \%)$, sponge spicules (trace to $10 \%)$, and radiolarians (trace to rare). Percent carbonate also displays the strong amplitude variability demonstrated by nannofossil ooze and detrital clay content (30 wt\%) (Fig. F27).

Figure F8 shows an X-ray diffractogram with peaks identified for minerals present in the carbonate-free fraction of Sample 306-U1313A-4H-2, 147-148 cm (27.17 mbsf). Relative intensity of peak heights from baseline indicates that the sample is dominated by detrital quartz. Other significant peaks are attributed to feldspar and clay minerals. Although no oriented glass slides were prepared from the clay size $(<4 \mu \mathrm{m})$ fraction, the presence of clay minerals can be discerned as significant from a number of prominent peaks between $0^{\circ}$ and $40^{\circ} 2 \theta$. A broad peak from $4^{\circ}$ to $8^{\circ} 2 \theta$ and a sharp peak at $20^{\circ} 2 \theta$ are characteristic of biotite mica and vermiculite and muscovite mica, respectively. A relatively strong peak at $12^{\circ} 2 \theta$ corresponds to the $001 \mathrm{~h}-\mathrm{k}-\mathrm{l}$ plane for kaolinite. The presence of biogenic silica is recognized from an amorphous hump between $20^{\circ}$ and $30^{\circ} 2 \theta$.

\section{Subunit IB}

Intervals: Sections 306-U1313A-5H-5, $130 \mathrm{~cm}$, through 13H-2, $66 \mathrm{~cm}$; 306-U1312B-5H-4, 48 $\mathrm{cm}$, through $13 \mathrm{H}-1,88 \mathrm{~cm} ; 306-\mathrm{U} 1313 \mathrm{C}-6 \mathrm{H}-$ $1,38 \mathrm{~cm}$, through $13 \mathrm{H}-4,30 \mathrm{~cm}$; and $306-$ U1313D-5H-2, $20 \mathrm{~cm}$, through 12H-6, 114 $\mathrm{cm}$ 
Depths: Hole U1313A: 41.00-111.86 mbsf, Hole U1313B: 39.38-111.28 mbsf, Hole U1313C: 41.08-112.00 mbsf, and Hole U1313D: 39.7$113.14 \mathrm{mbsf}$

Age: early Pleistocene-late Pliocene

This subunit consists of nannofossil ooze, nannofossil ooze with clay, and silty clay nannofossil ooze. Overall, percent biogenic carbonate is higher in Subunit IB, whereas detrital clay content is lower. Both are defined by decreased variability. This is reflected in reduced amplitude fluctuations of $L^{*}$ (Fig. F7), percent carbonate (Fig. F27), magnetic susceptibility (Fig. F32), magnetic intensity (Fig. F18), and GRA density (Fig. F35). Colors vary from white (N9 and $5 Y$ 8/1) to light gray (5Y 7/1) and gray (5Y 6/1), reflecting decimeter-scale variation in clay and biogenic carbonate content. Typical abundance of biogenic and terrigenous components, as estimated from smear slides, are nannofossils (60\%-98\%), clay $(0 \%-20 \%)$, foraminifers $(2 \%-10 \%)$, detrital calcite $(1 \%-5 \%)$, detrital quartz (1\%-5\%), diatoms (trace), and radiolarians (trace).

\section{Unit II}

Intervals: Sections 306-U1313A-13H-2, $66 \mathrm{~cm}$, through $33 \mathrm{H}-\mathrm{CC}, 22 \mathrm{~cm} ; 306-\mathrm{U} 1312 \mathrm{~B}-13 \mathrm{H}-$ 1 , $88 \mathrm{~cm}$, through 32-CC, $9 \mathrm{~cm}$; 306U1313C-13H-4, $30 \mathrm{~cm}$, through 32H-CC, 12 $\mathrm{cm}$; and 306-U1313D-12H-6, $114 \mathrm{~cm}$, through $16 \mathrm{H}-\mathrm{CC}, 14 \mathrm{~cm}$

Depths: Hole U1313A: 111.86-308.64 mbsf, Hole U1313B: 111.28-300.67 mbsf, Hole U1313C: 112.00-293.45 mbsf, and Hole U1313D: 113.14-152.34 mbsf

Age: late Pliocene-latest Miocene

Unit II consists of nannofossil ooze of late Pliocenelatest Miocene age. The change from Unit I to Unit II is gradational over $\sim 40 \mathrm{~m}$. It is defined by a change toward higher values and a reduction in variability of $\mathrm{L}^{*}$ (Fig. F7) and is coincident with a downcore reduction of percentage detrital clay and an increase in percentage biogenic carbonate, as well as decreased variability in both (see "Site U1313 smear slides" in "Core descriptions"). The transition is coincident with a consistent change in central tendency in percent carbonate, magnetic intensity, and resistivity. Decimeter-scale color banding is no longer apparent, and consistently high carbonate content is reflected in coloration, which varies only in shades of white (5Y 8/1 and N9). Occasional millimeter- to centimeter-scale diffuse bands of green and gray (5G 7/2 and N4-N5) are distributed throughout the sequence. Smear slides suggest that as much as 95\% of the lithology is composed of nannofossil ooze with clay contents $<5 \%$.Carbonate content averages $94 \mathrm{wt} \%$, with a range of $89-96 \mathrm{wt} \%$.
In Unit II, bioturbation is rare to moderate when observed. Lack of color contrast in this uniform lithology makes it difficult to estimate the degree of bioturbation, which may be totally bioturbated or homogenized. However, micronodules of pyrite are often present and likely located near burrows, and they may produce black streaks on the cut surface of the cores as a result of the core splitting process. Pyrite is also sporadically present in the form of burrow casts and nodules. Pyrite origin is probably related to local reducing conditions associated with organic matter complexes.

\section{Foraminifer "event" beds}

A number of millimeter- to centimeter-scale foraminifer nannofossil ooze beds occur in both units. Figure F9 demonstrates that the majority of these beds can be correlated with variable thickness across all four holes. These beds typically have a sharp, occasionally erosive, pyrite-rich base and, most commonly, gradational upper contacts. A number show normal grading. The most noteworthy of such layers is a decimeter-scale thick bed at 100.62-100.91 mbsf in Hole U1313A, 101.49-101.73 mbsf in Hole U1313C, and 103-103.29 mbsf in Hole U1313D (Fig. F10; Table T2). An equivalent layer was not observed in Hole U1313B and is shown to have been lost in a core break. The layer displays normal grading with a scour at the base and has been interpreted as a turbidite. It is not certain if all of these beds are the result of deposition by turbidity currents, although they probably represent reworked material.

\section{Ash beds}

A prominent ash layer was identified at 32.97-33.02 mbsf in Hole U1313A, 32.62-32.34 mbsf in Hole U1313B, 32.68 mbsf in Hole U1313C, and 32.8532.86 mbsf in Hole U1313D (see Figs. F9, F11). It is associated with a large positive magnetic susceptibility anomaly (see "Physical properties"). Smear slides show that these layers are composed almost exclusively of volcanic glass, opaque minerals, and minor quartz grains. In Hole U1313A, the ash layer displays a sharp erosive base and gradational upper contact. These factors, together with its variable thickness between the four holes, suggest that this ash layer does not represent deposition from settling through the water column but more likely reworking of older ash deposits, either locally or by turbidity currents.

\section{Dropstones}

Figure F9 and Table T3 summarize the occurrence of gravel-sized grains at Site U1313. The gravel-sized 
grains are interpreted as ice-rafted debris (IRD). Correlations can be made between regular intervals of IRD in meters below seafloor across all four holes in Unit I. Preliminary analysis of these dropstones shows that they typically range in size from 2 to 10 $\mathrm{mm}$ but can be as large as $30 \mathrm{~mm}$, especially in sediments of Subunit IA. Only two gravel-sized grains were found in Unit II. A millimeter-scale carbonate clast at 157.27 mbsf in Hole U1313A (Section 306U1313A-18H-1, $7 \mathrm{~cm}$ ) has been attributed to core flow-in and is not in situ. A $30 \mathrm{~mm}$ clast of basic igneous origin occurs at $176.32 \mathrm{mbsf}$ in Hole U1313A (Section 306-U1313A-20H-1, $12 \mathrm{~cm}$ ). Given its location at the top of Core 306-U1313A-20H, it also may not be in situ. Two of the most prominent events of increased IRD input are shown in Figures F12 and F13. Subangular to subrounded carbonate gravelsized grains occur in a decimeter-scale interval of silty clay nannofossil ooze at 57.60-58 mbsf in Hole U1313A (interval 306-U1313A-7H-4, 20-60 cm), 57.50-57.90 mbsf in Hole U1313B (interval 306U1313B-7H-3, $110-150 \mathrm{~cm}), 58.65-59.15 \mathrm{mbsf}$ in Hole U1313C (interval 306-U1313C-7H-6, 95-145 $\mathrm{cm}$ ) (Fig. F12), and 57.54-57.90 mbsf in Hole U1313D (interval 306-U1313D-7H-1, 54-90 cm). In Figure F13, a mixture of carbonate and mafic igneous gravel-sized grains occur in a matrix of decimeter-scale silty clay nannofossil ooze at 88.23-88.48 mbsf in Hole U1313A (interval 306-U1313A-10H-5, 103-128 cm) and 87.60-87.80 mbsf (interval 306U1313D-10H-4, 120-140 cm) and 88.83-89.08 mbsf $(10 \mathrm{H}-3,33-58 \mathrm{~cm})$ in Hole U1313D.

\section{Discussion}

The preliminary age model for Site U1313 indicates that lithologic changes described above may be related to northern hemisphere climate instability, with the main lithologic division between Unit I and II recording the onset of major northern hemisphere glaciation during the late Pliocene.

Unit II is characterized by uniformity in composition and color with high biogenic carbonate content. It is interpreted to record stable open-water pelagic sedimentation during the latest Miocene and late Pliocene. According to biostratigraphic and paleomagnetic results, the base of Unit I is placed at 2.62.7 Ma. Unit I, which is characterized by an increased but variable detrital clay content as reflected in decimeter-scale color banding, therefore, may record the evolution of northern hemisphere glaciation from this time (Raymo, 1992). An increase in the percentage and variability of the sediment detrital component may be explained by an expansion of northern hemisphere continental ice sheets and subsequent increased ice-rafting and eolian deposition connected to enhanced regional/hemispheric wind speeds. The onset of full glacial-interglacial conditions at this time is also reflected in accelerated North Atlantic bottom water cooling at $2.8 \mathrm{Ma}$ as determined from $\mathrm{Mg} / \mathrm{Ca}$ ratios in fossil ostracodes from Site 607 (Dwyer et al., 1995). A distinctive increase in the occurrence of dropstones found in this unit may be important in identifying IRD events, further highlighting that northern hemisphere ice sheet instability forms an important part of the sediment's paleoclimate record during the Holocene-late Pliocene. Further evidence for glacial-interglacial climate controlled changes in detrital input comes from a strong correlation of the lightness record with the global benthic oxygen isotope stack for the last 3.4 m.y. (Lisiecki and Raymo, 2005) (Fig. F24).

This preliminary correlation makes it possible to place the timing of the transition from Subunit IB to IA at $0.9 \mathrm{Ma}$ within the "Mid-Pleistocene Revolution," which marks the transition from the 41 to 100 k.y. world (Imbrie et al., 1993). This also is reflected in more distinct maxima and minima in biogenic carbonate and detrital clay components and is mirrored by a distinct change in percent carbonate variance.

\section{Biostratigraphy}

Core catcher samples from Holes U1313A through U1313D contain rich assemblages of calcareous nannofossils and planktonic foraminifers that are well to moderately well preserved. A succession of calcareous nannofossil and planktonic foraminifer events provide a reliable biostratigraphic framework that, in the upper part, is supported by the siliceous plankton biostratigraphic zones for much of the cored intervals (Table T4).

According to the age of biostratigraphic events recognized in this study, Site U1313 provided a sedimentary sequence encompassing the latest MioceneHolocene (Figs. F14, F15, F16, F17). The oldest sediments are tentatively dated at $6.0 \mathrm{Ma}$ based on the last occurrence (LO) of the calcareous nannofossil Amaurolithus amplificus in Samples 306-U1313A$32 \mathrm{H}-\mathrm{CC}$ and 306-U1313C-32H-CC and the possible first abundant occurrence $(\mathrm{FaO})$ of the planktonic foraminifer Globorotalia margaritae in Sample 306U1313A-33H-CC. Sediments from the Pliocene and Pleistocene contain abundant planktonic foraminifers in relation to calcareous nannofossils, whereas planktonic foraminifer abundances in upper Miocene sediments are reduced relative to nannofossils. Specimens of planktonic and benthic foraminifers are small in the lowermost $50 \mathrm{~m}$ (upper Miocene), and most are of similar size. This sorting and the lack 
of large individuals seem to indicate the foraminifers have been transported and deposited in the deepest part of the basin where this site is located. The cooccurrence of frequent fragments of large, heavily calcified benthic foraminifers with mostly unbroken planktonic foraminifers of similar size indicates deposition in a current-influenced environment. The relatively high proportion of fragments of benthic shells also indicates transport from an area of intensive carbonate dissolution.

Comparison of age-depth plots from Holes U1313A through U1313D show very similar, consistent sedimentation rates of $4.1-4.5 \mathrm{~cm} / \mathrm{k} . \mathrm{y}$. throughout the Pliocene and Pleistocene (Figs. F14, F15, F16, F17). Although the stratigraphic framework for the late Miocene is less constrained, sedimentation rates in the late Miocene appear to be much higher (13-14 $\mathrm{cm} / \mathrm{k} . \mathrm{y}$.$) .$

\section{Calcareous nannofossils}

We examined all core catcher samples from Holes U1313A through U1313D for calcareous nannofossils. Additional samples were taken from Cores 306$\mathrm{U} 1313 \mathrm{~A}-3 \mathrm{H}$ and $6 \mathrm{H}$, as well as 306-U1313B-2H through $12 \mathrm{H}$ to refine the biostratigraphy. All samples yielded abundant to very abundant nannofossil assemblages. Preservation was generally good to moderately good throughout the Pliocene and Pleistocene sediments. Upper Miocene calcareous nannofossils were moderately to moderately well preserved, with some discoasters exhibiting significant overgrowth. Gephyrocapsids, small reticulofenestrids, and Pseudoemiliania species dominate Pleistocene assemblages, whereas Pliocene and Miocene assemblages are dominated by reticulofenestrids of all sizes. Very rare reworked nannofossils occur in all holes, especially within the Pleistocene and upper Pliocene sediments.

The sections recovered at Site U1313 yielded Pleistocene, Pliocene, and upper Miocene assemblages (Tables T5, T6, T7, T8, T9). Higher sedimentation rates than those at Site U1312 allowed us to identify the 12 Pleistocene nannofossil datums defined by Sato et al. (1999) in most holes at Site U1313. Most core catchers yielded a new datum, so we took subsamples from many of the Pleistocene cores in Hole U1313B to further resolve the biostratigraphy. The LO of Helicosphaera inversa (0.16 Ma) occurs in Samples 306-U1313A-1H-CC, 306-U1313C-1H-CC, and 306-U1313D-1H-CC; however, the single specimen in Hole U1313C may be reworked, and therefore the LO of $H$. inversa is placed in Sample 306-U1313C-2H$\mathrm{CC}$ of that hole. The $\mathrm{LO}$ of this species also occurs in Sample 306-U1313B-2H-3, 10-11 cm. The first occurrence (FO) of Emiliania huxleyi (0.25 Ma), which marks the base of Martini's (1971) Zone NN21, is present in Samples 306-U1313A-3H-2, top, 306U1313B-2H-CC, 306-U1313C-2H-CC, and 306U1313D-1H-CC. This event was problematic because E. huxleyi is difficult to recognize under the light microscope. In Hole U1313D, Zone NN20, which spans the time interval between the LO of Pseudoemiliania lacunosa and the FO of E. huxleyi, occurs in Sample 306-U1313D-2H-CC. This zone was not identified in any other holes at this site, due in part to the difficulty of determining the presence or absence of $E$. huxleyi.

The LO of P. lacunosa (0.41 Ma), which defines the top of Zone NN19, is found in Samples 306-U1313C3H-CC and 306-U1313D-3H-CC. Subsamples taken from Holes U1313A and U1313B yielded the LO of $P$. lacunosa in Samples 306-U1313A-3H-2, top, and 306U1313B-3H-3, 84-87 cm. The FO of $H$. inversa $(0.51$ $\mathrm{Ma}$ ) is present in Samples 306-U1312A-3H-2, top, 306-U1312B-3H-3, 84-87 cm, 306-U1313C-2H-CC, and 306-U1313D-2H-CC. The absence of $H$. inversa in conjunction with the FO of P. lacunosa in Samples 306-U1313C-3H-CC and 306-U1313D-3H-CC indicates the uppermost part of Zone NN19 (between 0.41 and $0.51 \mathrm{Ma}$ ) occurs somewhere within Core $3 \mathrm{H}$ in those holes. The LO of Reticulofenestra asanoi also occurs in Samples 306-U1313A-3H-CC, 306-U1313B4H-3, 102-105 cm, 306-U1313C-4H-CC, and 306U1313D-4H-CC. Additionally, the FO of Gephyrocapsa parallela $(0.95 \mathrm{Ma})$ occurs in Samples 306U1313A-4H-CC, 306-U1313B-5H-4, 18-20 cm, 306U1313C-5H-CC, and 306-U1313D-4H-CC. The FO of R. asanoi (1.16 Ma) occurs in Samples 306-U1313A5H-CC, 306-U1313B-5H-CC, 306-U1313C-5H-CC, and 306-U1313A-5H-CC.

The LO of large Gephyrocapsa spp. (1.21 Ma) occurs in Samples 306-U1313A-6H-6, 57 cm, 306-U1313B6H-CC, and 306-U1313C-6H-CC. This species, which ranges from 1.21 to $1.45 \mathrm{Ma}$, was not found in any of the core catchers from Hole U1313D, and so its entire range must fall within one of the cores in that hole. The LO of Helicosphaera sellii (1.27 Ma) was difficult to pick with certainty as very rare reworked occurrences are found within the upper Pleistocene sections of Holes U1313A, U1313B, and U1313C. We placed the event in Samples 306-U1313A-7H-CC, 306-U1313B-7H-4, 60-63 cm, and 306-U1313C-7HCC. This event appears slightly higher in Hole U1313D (Sample 306-U1313D-6H-CC). The FO of large Gephyrocapsa spp. (1.45 Ma) occurs in Samples 306-U1313A-7H-CC, 306-U1313B-7H-CC, and 306U1313C-8H-CC.

The FOs of Gephyrocapsa oceanica (1.65 Ma) and Gephyrocapsa caribbeanica (1.73 Ma) occur together in all holes at Site U1313. We use the latter species to 
approximate the Pliocene/Pleistocene boundary. These events occur in Samples 306-U1313A-8H-CC, 306-U1313B-9H-1, 83-90 cm, 306-U1313C-9H-CC, and 306-U1313D-8H-CC. A rare occurrence of G. oceanica co-occurs with Discoaster brouweri in Sample 306-U1313A-10H-CC. This pattern of very rare Gephyrocapsa spp. $(>4 \mu \mathrm{m})$ occurrences below the Pliocene/Pleistocene boundary is consistent with results from Site U1312 and reports of similar occurrences from Blake Ridge, northwest Atlantic (Okada, 2000). Thus, the FOs of G. oceanica and G. caribbeanica are placed at the base of consistent occurrences of the species, and it is this horizon we use to approximate the boundary.

Pleistocene sediments at Site U1313 contain very rare reworked material throughout much of the interval. Reticulofenestra pseudoumbilicus and, to a lesser extent, Sphenolithus abies are the most frequent reworked species, although only one or two specimens are typically found in any sample. Some discoasters also occur sporadically throughout this section. Since we only looked at one or two samples per core, the reworked material in those samples made picking the LOs of some of the Pliocene events difficult, as discussed below.

Five Pliocene events dated by Sato et al. (1999), one by Shackleton et al. (1995), and one by Backman and Raffi (1997) occur within the sedimentary section at Site U1313. The LO of D. brouweri (1.97 Ma), which marks the top of Zone NN18, occurs in Samples 306U1313A-10H-CC, 306-U1313B-9H-CC, 306-U1313C10H-CC, and 306-U1313D-9H-CC. Very rare reworked occurrences of $D$. brouweri are found in Holes U1313A and U1313B, making it difficult to accurately identify this extinction event in these holes. Discoaster pentaradiatus also occurs sporadically above its LO in several holes. The LO of $D$. pentaradiatus (2.38 Ma), which marks the top of Zone NN17, is located in Samples 306-U1313A-11H-CC, 306U1313B-12H-1, 80-87 cm (along with single reworked specimens of Discoaster surculus and Discoaster tamalis), 306-U1313C-12H-CC, and 306U1313D-11H-CC. The LO of D. surculus (2.54 Ma), which marks the top of Zone NN16, occurs in Samples 306-U1313A-12H-CC, 306-U1313B-12H-CC, 306-U1313C-12H-CC, and 306-U1313D-12H-CC. In Hole U1313C, this event is placed at the same horizon as the LO of $D$. pentaradiatus. These events may be separated within Core 306-U1313C-12H, or the occurrence of $D$. surculus in the core catcher sample may be reworked. The LO of D. tamalis $(2.74 \mathrm{Ma}$ ) occurs in Samples 306-U1313A-13H-CC, 306-U1313B13H-CC, 306-U1313C-12H-CC, and 306-U1313D$13 \mathrm{H}-\mathrm{CC}$. The occurrence of this species higher in Hole U1313C may also be attributed to reworking, as very rare reworked occurrences are found in samples from all holes except Hole U1313A.

Most core catcher samples from the lowermost Pleistocene and uppermost Pliocene contain very rare reworked discoasters. Often these specimens are fragmented, whereas the in situ material is well preserved. Some of the additional samples from Hole U1313B did not contain reworked material; therefore examination of more closely-spaced samples should result in more precise placement of discoaster LOs within the upper Pliocene.

The intervals from Samples 306-U1313A-13H-CC through 17H-CC, 306-U1313B-13H-CC through 17H-CC, 306-U1313C-12H-CC through 18H-CC, and 306-U1313D-13H-CC through total depth are characterized by the occurrence of $D$. tamalis and very rare reworked occurrences of $R$. pseudoumbilicus $(>7 \mu \mathrm{m})$ in nearly every sample, indicating an age between 2.74 and $3.85 \mathrm{Ma}$. The persistent nature of reworked $R$. pseudoumbilicus made it very difficult to identify the true LO of this species, which occurs at $3.85 \mathrm{Ma}$ and marks the top of Zone NN15. We placed this event at the top of consistent co-occurrences of $R$. pseudoumbilicus and S. abies, which occurs in Samples 306-U1313A-17H-CC, 306-U1313B-17H-CC, and 306-U1313C-18H-CC.

Two datums from the lower Pliocene are identified at Site U1313, although both are somewhat problematic. The LO of Amaurolithus primus, which approximates the top of Zone NN14, is dated at $4.56 \mathrm{Ma}$ in the eastern equatorial Pacific by Shackleton et al. (1995). This event, which is equivalent to the LO of the genus Amaurolithus, occurs very consistently within the holes at this site and is located in Samples 306-U1313A-18H-CC, 306-U1313B-18H-CC, and 306-U1313C-19H-CC. The planktonic foraminifer datums from equivalent horizons yield a younger age of $3.81 \mathrm{Ma}$ (Table T10). There are two possibilities: the amauroliths are consistently reworked above their true LO at this site or the age of the LO of Amaurolithus in the northwest Atlantic is younger than that documented in the eastern equatorial $\mathrm{Pa}$ cific. As a result, we cannot rely on this event for biostratigraphy at this site.

Ceratolith species are generally rare but consistent at Site U1313. Several questionable occurrences of Ceratolithus acutus occur in Holes U1313A and U1313B; however, these occurrences are not persistent enough to use the LO of $C$. acutus, which occurs at $5.046 \mathrm{Ma}$, as a datum. The FO of Ceratolithus rugosus, which is considered an overgrown form of the species Ceratolithus cristatus (Bergen, 1984; Young, 1998), can be identified at this site. Backman and Raffi (1997) date the FO of C. rugosus to 5.089 Ma. This event approximates the top of Zone NN12 and 
occurs in Samples 306-U1313A-23H-CC, 306U1313B-21H-CC, and 306-U1313C-22H-CC.

Two nannofossil events dated by Backman and Raffi (1997) are identified from the upper Miocene sediments at Site U1313. The LO of Discoaster quinqueramus $(5.537 \mathrm{Ma})$, which we use to approximate the Miocene/Pliocene boundary (5.332 Ma), is difficult to identify at this site. Discoasters within the lowermost Pliocene and uppermost Miocene sediments are generally overgrown, making it difficult to identify the LO of $D$. quinqueramus. We placed the event at the top of definitive specimens of $D$. quinqueramus; however, the true LO could be higher. This event, which marks the top of Subzone NN11D, occurs in Samples 306-U1313A-25H-CC, 306-U1313B25H-CC, and 306-U1313C-25H-CC. The LO of $A$. amplificus (5.999 Ma), which marks the top of Subzone NN11C, comes in very consistently near the bottom of Holes U1313A and U1313C in Samples 306-U1313A-32H-CC and 306-U1313C-32H-CC. Several occurrences of this species in Samples 306U1313B-26H-CC and 306-U1313B-27H-CC were initially interpreted as the $\mathrm{LO}$ of this species in Hole U1313B. The consistent occurrences at the base of Holes U1313A and U1313C and the absence of the species below Core 306-U1313B-27H in Hole U1313B have led us to reinterpret the $A$. amplificus occurrences uphole in Hole U1313B as reworked (Fig. F15; Table T6). Thus, the base of Hole U1313B may be just above the true LO of $A$. amplificus.

\section{Planktonic foraminifers}

We studied the planktonic foraminifer assemblages in all core catchers from Holes U1313A through U1313D (Tables T11, T12, T13, T14). In addition, the washout from the top of Cores 306-U1313B-1H and $306-\mathrm{U} 1313 \mathrm{C}-1 \mathrm{H}$, for which only the $>150 \mu \mathrm{m}$ fraction is available, was examined. All samples were washed with tap water. Planktonic foraminifers dominate the sand fraction in all core catchers and are mainly moderately to well preserved. The foraminifer assemblage in the core catcher samples consists of 11 to 20 different species. Subtropical to tropical species are present in nearly every sample. Some core catcher samples are from glacial or stadial periods, as they contain small amounts of IRD.

The interhole variability in the occurrence of the stratigraphic events is highlighted in Table T10. All age model-relevant events are also placed into the context of the other microfossil group biostratigraphic events in Table T4.

The $\mathrm{FaO}$ of Neogloboquadrina pachyderma (sinistral), dated at $1.78 \mathrm{Ma}$ (Weaver and Clement 1987), is probably related to the advection of cold waters to mid-latitudes of the North Atlantic because this po- lar species only reaches higher abundances in the Pleistocene under full glacial conditions. Consequently, its abundance in the core catcher samples depends on the time interval recovered in the core catcher, and only in Sample 306-U1313A-8H-CC does it seem to occur in the correct stratigraphic position (Table T10). Encrusted N. pachyderma (sinistral) appears for the first time in Samples 306U1313B-8H-CC and 306-U1313C-8H-CC only in rare abundances.

An incursion of large-sized ( $>250 \mu \mathrm{m})$, heavily encrusted Neogloboquadrina atlantica (dextral) is observed in the lower Pleistocene. The onset of this incursion occurs in Samples 306-U1313A-9H-CC, 306U1313B-9H-CC, 306-U1313C-9H-CC, and 306U1313D-9H-CC and coincides with the bottom of the Olduvai polarity chron $(1.95 \mathrm{Ma})$. The incursion is present until Samples 306-U1313A-7H-CC, 306U1313B-7H-CC, 306-U1313C-7H-CC, and 306U1313D-6H-CC. Using a preliminary age model for Site U1313, these core catcher samples are dated between 1.52 and $1.4 \mathrm{Ma}$ (see "Stratigraphic correlation"). The youngest LO reported for this species is 1.84 Ma at ODP Site 644 (Spiegler and Jansen, 1989), but the great resemblance between the specimens found at Site U1313 and those used by Berggren (1972) to define the species clearly identifies them as $N$. atlantica. The incursion of this subpolar species is contemporaneous with an increase in IRD deposition (see "Lithostratigraphy") and therefore clearly indicates the advance of cold northern source waters as far south as Site U1313 in the early Pleistocene.

The FO of Globorotalia truncatulinoides occurs one or two cores above the FO of Globorotalia inflata in all four holes. This suggests that these FOs most likely correlate with the more abundant occurrences of this species observed at $1.92 \mathrm{Ma}$ in DSDP Site 607 by Spencer-Cervato and Thierstein (1997), and not with the very first trace occurrences dated at 2.14 Ma by the same authors. The FO of G. inflata, dated at 2.09 $\mathrm{Ma}$ in the North Atlantic and Mediterranean (Weaver and Clement, 1987), occurs in Samples 306U1313A-10H-CC, 306-U1313B-10H-CC, 306U1313C-9H-CC, and 306-U1313B-10H-CC.

As with the FO of G. inflata, the LO of Globorotalia puncticulata also occurs at the same level in Holes U1313A, U1313B, and U1313D (Sample 12H-CC) and one core higher in Hole U1313C (Sample 11HCC). This event, dated at $2.41 \mathrm{Ma}$, was calibrated to the astronomical timescale in the Mediterranean (Lourens et al., 1996). The LOs of Globorotalia miocenica and $N$. atlantica (sinistral) (at $2.4 \mathrm{Ma}$ ) nearly coincide with that of G. puncticulata (Weaver and Clement, 1987). The three biostratigraphic events, however, never occur in the same core catcher sam- 
ple, but in Holes U1313B and U1313D two of these events coincide in Samples 306-U1313B-12H-CC and 306-U1313D-12H-CC. The scatter in the biostratigraphic events is easily explained because $G$. miocenica, whose abundance is rare, lived in tropical waters and $N$. atlantica (sinistral) in temperate to polar waters. From time to time, N. atlantica invaded the mid-latitude waters of the North Atlantic and Mediterranean and changed its coiling direction several times from the late Miocene to the Pleistocene. The LO of N. atlantica (sinistral) occurs in Samples 306U1313B-12H-CC, 306-U1313C-12H-CC, and 306U1313D-11H-CC. This event was dated in the North Atlantic at 2.4 Ma (Weaver and Clement, 1987) and probably coincides with the disappearance of the species in the Mediterranean (Lourens et al., 1996).

An interval with relatively abundant Globorotalia hirsuta is found in all holes from approximately Samples $15 \mathrm{H}-\mathrm{CC}$ to $18 \mathrm{H}$-CC. These specimens were previously identified by Weaver and Clement (1987) as Globorotalia cf. crassula. The highly convex dorsal side, however, led us to relate these forms to G. hirsuta, which evolved from G. margaritae in the late Pliocene (Kennett and Srinivasan, 1983). These forms become a significant component of the assemblages after the extinction of G. margaritae and disappear at $23.1-3.2 \mathrm{Ma}$ (Weaver and Clement, 1987). After its temporal disappearance, this species is not present again until the late Pleistocene and Holocene. Its disappearance is approximately coetaneous with the LO of Sphaeroidinellopsis seminulina (3.19 Ma) (Weaver and Clement, 1987; Lourens et al., 1996). The LO of $S$. seminulina occurs in Samples 306-U1313A-15H-CC, 306-U1313B-15H-CC, and 306-U1313C-15H-CC, but is not observed in Hole U1313D.

Similar to records from the Mediterranean Sea, a well-defined gap in the presence of G. puncticulata (Lourens et al., 1996) is observed in all holes at Site U1313. In the Mediterranean, this gap occurs between 3.31 and $3.57 \mathrm{Ma}$ (Lourens et al., 1996). In Holes U1313A and U1313C, the reappearance of $G$. puncticulata occurs in the same core catcher samples as the LO of S. seminulina or the disappearance of $G$. hirsuta (Samples 306-U1313A-15H-CC and 306U1313C-15H-CC).

The next biostratigraphic marker horizons are the $\mathrm{LO}$ and the last common occurrence of G. margaritae, which take place in consecutive core catcher samples in the three deeper holes, (i.e., Samples 306-U1313A$18 \mathrm{H}-\mathrm{CC}$ and 19H-CC, 306-U1313B-18H-CC and 19H-CC, and 306-U1313C-19H-CC and 20H-CC). This event, reported by Weaver and Clement (1987) to be diachronous between the high and low latitudes, is dated to $3.98 \mathrm{Ma}$ in the Mediterranean
(Lourens et al., 1996). As Site U1313 is at a similar latitude, we use the Mediterranean age for this marker event.

The previous event is directly preceded by the FOs of G. puncticulata and Globorotalia crassaformis, which occur together in Samples 306-U1313A-20H-CC, 306-U1313B-20H-CC, and 306-U1313C-21H-CC (Table T10). This event can be traced throughout the North Atlantic and Mediterranean. It is calibrated to the astronomical timescale and dated to $4.52 \mathrm{Ma}$ (Lourens et al., 1996).

The oldest definitive age marker at Site U1313 is the LO of Globigerina nepenthes during the Sidufjall magnetic subchron, which lasted from 4.89 to $4.8 \mathrm{Ma}$. This event occurs in Samples 306-U1313A-22H-CC, 306-U1313B-22H-CC, and 306-U1313C-23H -CC.

For the lower parts of the three deeper holes, no stratigraphic event could be placed with great certainty. The next biostratigraphic event would be the $\mathrm{FaO}$ of G. margaritae at $\sim 6.0 \mathrm{Ma}$ near the top of the C3A.1n Chron (F.J. Sierro, unpubl. data). At Site U1313, however, G. margaritae is relatively common in most samples analyzed from the lowermost cores, with only Sample 306-U1313A-33H-CC containing rare specimens of this species. Based on these data, the $\mathrm{FaO}$ of $G$. margaritae can tentatively be placed in Sample 306-U1313A-33H-CC. Beginning at $6.3 \mathrm{Ma}$, $N$. pachyderma, which is preferentially sinistral in the late Miocene, underwent a series of changes in the coiling direction to become dominantly dextral during the Pliocene (Hilgen and Krijgsman, 1999; Sierro et al., 2001; Hodell et al., 2001). Analysis of coiling direction of this species indicates that from Samples 306-U1313A-33H-CC through 26H-CC, 306U1313B-33H-CC through 26H-CC, and 306U1313C-32H-CC through 27H-CC, N. pachyderma underwent some fluctuations in coiling direction, which are typical for the latest part of the Messinian. Even though the lowermost samples of Holes U1313A and U1313B contain abundant numbers of $N$. pachyderma (sinistral), the remaining occurrences of $G$. margaritae and the scarcity of specimens of the Globorotalia miotumida group indicate that the oldest sediments recovered at Site U1313 are younger than 6.3 Ma and somewhere closer to 6.0 Ma. Furthermore, the G. miotumida group, including Globorotalia conomiozea, was dominant in the North Atlantic and Mediterranean between 7.2 and 6.3 Ma (Sierro et al., 1993); however, only a few specimens of this group are observed in the bottommost samples of this site.

\section{Benthic foraminifers}

Benthic foraminifer assemblages from Site U1313 were only studied in Hole U1313A. Few moderately well preserved benthic foraminifers occur through- 
out the Neogene sequence, except in Sample 306U1313A-28H-CC, which contains very rare, poorly preserved specimens (Table T15). Four assemblages are determined for this site.

\section{Assemblage I (Epistominella exigua-Uvigerina proboscidea)}

This assemblage occurs between Samples 306U1313A-1H-CC and 3H-CC and is characterized by the highest abundance of $E$. exigua and $U$. proboscidea and common occurrences of Globocassidulina subglobosa.

\section{Assemblage II (Oridorsalis umbonatus)}

This assemblage occurs between Samples 306U1313A-3H-CC and 11H-CC and is characterized by the abundant occurrence of O. umbonatus.

\section{Assemblage III (Globocassidulina subglobosa)}

This assemblage is found from Samples 306-U1313A$12 \mathrm{H}-\mathrm{CC}$ through $15 \mathrm{H}-\mathrm{CC}$, and also from $20 \mathrm{H}-\mathrm{CC}$ through $23 \mathrm{H}$-CC. It is represented by the highest abundances of G. subglobosa.

\section{Assemblage IV (Nuttallides umboniferus)}

This assemblage is represented by abundant occurrences of N. umboniferus and is recognized in Samples 306-U1313A-16H-CC through 18H-CC and below Core $24 \mathrm{H}$.

Studies of benthic foraminifers in the modern Atlantic Ocean have shown that foraminiferal biofacies are well correlated with individual water masses (e.g., Murray, 1991). Murray (1991) identified specific foraminiferal biofacies associated with NADW and AABW. Whereas G. subglobosa and O. umbonatus are present beneath NADW, N. umboniferus prefers deeper water depths under the influence of AABW. In addition, G. subglobosa, Melonis barleeanus, and Uvigerina peregrina are dependent on food availability (Murray, 1991) and E. exigua is an opportunistic species linked to seasonal deposition of phytodetritus on the seafloor (Thomas et al., 1995). Thus, their high abundances may indicate an increased flux of organic matter, even if only seasonally.

Benthic foraminifer assemblages from Hole U1313A suggest sediments above Sample 306-U1313A-3H-CC (0.41-0.85 Ma) (Table T4) were probably deposited under the influence of NADW. The relatively high abundances of E. exigua and G. subglobosa suggest an increased supply of phytodetritus to the seafloor and thereby at least seasonal high productivity in the surface waters at Site U1313. Sediments between Samples 306-U1313A-4H-CC and 15H-CC also show evidence of NADW influence, particularly from 0.85 to $2.74 \mathrm{Ma}$ and also from $4.56(?)$ to $5.089 \mathrm{Ma}$. Prior to $2.38 \mathrm{Ma}$, the high abundance of $G$. subglobosa reveals either high organic carbon flux to the seafloor or sluggish deepwater circulation (Thomas et al., 1995). Although increased organic carbon is not preserved in the sediments (see "Geochemistry"), seasonally high phytodetritus fluxes could have caused the blooms of G. subglobosa, especially because $E$. exigua is also present in minor numbers. Between 3.85 and 4.56(?) Ma and before $5.089 \mathrm{Ma}$, N. umboniferus dominates the fauna in most core catchers, suggesting the influence of AABW at Site U1313 and thereby shoaling of the NADW/AABW interface, at least during the intervals recovered in the core catcher samples.

The only benthic foraminifer biostratigraphic event recognized at Site U1313 is the LO of Stilostomella lepidula, which occurs in Sample 306-U1313A-5HCC. Most species of Stilostomella disappeared between 1.0 and 0.6 Ma (Hayward, 2001). Thus, the age indicated by the benthic foraminifers coincides with the nannofossil results.

\section{Diatoms}

Diatoms were investigated in smear slides from 113 core catcher samples from Holes U1313A through U1313D (Tables T16, T17, T18, T19). In addition, Core 306-U1313C-32H was investigated at $10 \mathrm{~cm}$ resolution in an attempt to constrain the age of the bottom of the hole. Diatoms are generally present within the Pliocene-Pleistocene intervals (from 0 to 40-70 m); however, they are usually only abundant in the uppermost two core catchers and occur only occasionally as traces below 50-60 m. Silicoflagellates are generally present with the diatoms. Placement of defined datums (Baldauf, 1987) was therefore difficult due to the generally low abundance of diatoms.

The base of the Fragilariopsis doliolus Zone, defined by the LO of Fragilariopsis reinholdii (0.48-0.45 Ma), occurs in Samples 306-U1313A-4H-CC, 306-U1313B4H-CC, and 306-U1313D-4H-CC. In Hole U1313C, this event occurs in Sample 306-U1313C-5H-CC, but this is the only occurrence of that species in Hole U1313C. The LO of Proboscia curvirostris is observed in Samples 306-U1313A-2H-CC, 306-U1313B-2HCC, and 306-U1313D-2H-CC, supporting an age of at least $0.3 \mathrm{Ma}$ for those sediments.

The $F$. reinholdii Zone is represented by the co-occurrence of $F$. reinholdii and $F$. doliolus and is constrained at the base by the FO of $F$. doliolus. In Holes U1313A and U1313B, the FO of $F$. doliolus occurs in Samples 306-U1313A-4H-CC and 306-U1313B-4H-CC. In Hole U1313C, this event is found in Sample 306U1313C-1H-CC. The LO of F. reinholdii should be 
stratigraphically above the FO of $F$. doliolus. These events are reversed in Hole U1313C, which is likely an artifact of very low concentrations of diatoms in the sediment, making them more susceptible to influence by contamination. The same reversal is present in Hole U1313D, where the FO of $F$. doliolus occurs in Sample 306-U1313D-3H-CC and the LO of F. reinholdii occurs in Sample 306-U1313D-4H-CC. Again, this is more likely a function of low diatom abundances than any disturbance in the cores.

Section 306-U1313C-32H-2 includes Thalassiosira convexa in several samples, suggesting a maximum age of $6 \mathrm{Ma}$ for the upper part of this core (Baldauf, 1987). However, as the abundances of T. convexa are very low and the surrounding samples contain no diatoms, the occurrences are not suitable for biostratigraphic use. Unfortunately, it was not possible to establish a diatom-based biostratigraphy below the $F$. reinholdii Zone because of the low abundances of diatoms.

The diatom flora is diverse in all holes, especially within the upper $4-5$ core catchers. A total of 74 categories were applied at this site, including 45 diatom species, several generic groups, identification of fragmented specimens, and several types of silicoflagellates. The assemblage is dominated by warm-water flora (Baldauf, 1987), including Coscinodiscus nodulifer, Thalassiora oestrupii group, Alveus marinus, Thalassionema nitzschioides group, $F$. doliolus, F. reinholdii, and F. fossilis. Chaetoceros resting spores are often present, indicating high productivity.

The upper core catchers of all holes contain plentiful Thalassiothrix fragments, as well as Actinocyclus curvatulus, indicating influence from Arctic and subarctic waters (Andersen et al., 2004). Neodenticula seminae in Samples 306-U1313A-1H-CC through 4H-CC, 306-U1313B-1H-CC through 4H-CC, and 306U1313C-1H-CC through $4 \mathrm{H}-\mathrm{CC}$, as well as partly dissolved specimens of Triceratium and Trochosira in Sample 306-U1313C-1H-CC, suggest transport of diatoms from colder waters in the upper Pleistocene sections of Site U1313 (Koç et al., 1999; Schrader and Fenner, 1976).

\section{Radiolarians}

We examined radiolarians in all core catcher samples from Site U1313 (Tables T20, T21, T22, T23).

In Hole U1313A, 5 of 33 core catcher samples (306U1313A-10H-CC, 14H-CC, 15H-CC, 16H-CC, and 19H-CC) include no radiolarians (Table T20). Radiolarians are abundant and well preserved in Samples 306-U1313A-1H-CC through 5H-CC and are common and moderately preserved in Samples 306U1313A-9H-CC, 12H-CC, 25H-CC, 26H-CC, 30H$\mathrm{CC}$, and $33 \mathrm{H}-\mathrm{CC}$.
Some age-diagnostic species used in the mid-latitude North Atlantic by Haslett $(1994,2004)$ and Ciesielski and Bjørklund (1995) were encountered in this hole. The FO of Pterocorys hertwigii is dated to 0.75-0.87 Ma (Haslett, 1994; 2004) and is observed in Samples 306-U1313A-1H-CC and 2H-CC. However, Sample 306-U1313A-2H-CC, which contains the oldest occurrence of this species in Hole U1313A, is younger than $0.25 \mathrm{Ma}$ based on the FO of the nannofossil $E$. huxleyi. Its absence below 306-U1313A-2H-CC indicates the occurrence of $P$. hertwigii depends on oceanographic conditions because the distribution of this species in surface sediments is restricted to low latitudes (Caulet and Nigrini, 1988). Thus, the FO datum of $P$. hertwigii in the North Atlantic is considered unreliable.

The FO of Cycladophora davisiana is dated to $2.6 \mathrm{Ma}$ (Haslett, 1994, 2004; Ciesielski and Bjørklund, 1995), and this datum was compatible with other microfossil data at Site U1312. In Hole U1313A, however, the FO of $C$. davisiana occurs in Sample 306-U1313A$25 \mathrm{H}-\mathrm{CC}$, where the age is dated to $5.5 \mathrm{Ma}$ by the LO of the nannofossil D. quinqueramus.

The LO of Stichocorys peregrina is dated to 2.65-2.8 Ma (Haslett, 1994, 2004). This species is found only in Samples 306-U1313A-25H-CC, 26H-CC, 30H-CC, and $33 \mathrm{H}-\mathrm{CC}$, where radiolarians are common and moderately preserved. The uppermost occurrence of this species in Sample 306-U1313A-25H-CC is dated to $5.5 \mathrm{Ma}$ (LO of D. quinqueramus) in this hole. This discrepancy in the age of the LO of $S$. peregrina may result from one of two reasons. First, the preservation is poor and its occurrence might be hampered by dissolution. Second, as $S$. peregrina is a tropical/ subtropical species, its absence might be due to ecological conditions in this area. Therefore, we regard the LO of $S$. peregrina in our samples as not reliable biostratigraphically.

In Hole U1313B, abundant to common radiolarians, with good to moderate preservation, are present in Samples 306-U1313B-3H-CC through 7H-CC, except in $6 \mathrm{H}-\mathrm{CC}$, which contains few, poorly preserved radiolarians (Table T21). Radiolarians are also common but poorly preserved in Sample 306-U1313B$32 \mathrm{H}-\mathrm{CC}$. All other core catcher samples yield only traces of opal with overall poor to moderate preservation. Two samples (306-U1313B-20H-CC and 21HCC) are barren of radiolarians.

The FO of C. davisiana occurs in Sample 306U1313B-29H-CC. This sample is dated to at least 5.5 Ma by the LO of $D$. quinqueramus. The $C$. davisiana datum again occurs much earlier than the expected 2.6 $\mathrm{Ma}$ in this hole but is synchronous with the event in Hole U1313A. In Samples 306-U1313B-30H$\mathrm{CC}$ and $32 \mathrm{H}-\mathrm{CC}, S$. peregrina is present, but poor 
preservation does not allow for a firm determination of its LO (2.65-2.8 Ma).

Moderate to well preserved radiolarians are abundant to common in the uppermost four cores of Hole U1313C (Table T22). Common radiolarians are also present in Samples 306-U1313C-6H-CC, 9H-CC, $27 \mathrm{H}-\mathrm{CC}$, and $31 \mathrm{H}-\mathrm{CC}$. The preservation is good in the first two samples and moderate in the latter two. The remaining core catcher samples contain only traces of radiolarians and the preservation is generally poor to moderate.

The first occurrence of $C$. davisiana occurs in Sample 306-U1313C-27H-CC (5.5-6.0 Ma). This is synchronous with its FO in Holes U1313A and U1313B. S. peregrina occurs in Samples 306-U1313C-26H-CC, $27 \mathrm{H}-\mathrm{CC}, 30 \mathrm{H}-\mathrm{CC}$, and $31 \mathrm{H}-\mathrm{CC}$, but poor preservation does not allow us to determine its LO, dated at 2.65-2.8 Ma (Haslett, 1994).

Abundant, well-preserved radiolarians are observed in the uppermost four cores of Hole U1313D, except for Sample 306-U1313D-1H-CC, where radiolarians are rare and poorly preserved (Table T23). Poorly preserved radiolarians generally occur as traces or are rare in the remainder of Hole U1313D (Samples 306U1313D-5H-CC through 16H-CC); however, in Sample 306-U1313D-8H-CC, radiolarians are abundant and moderately preserved.

C. davisiana occurs in the following six samples: 306U1313D-2H-CC, 3H-CC, 4H-CC, 8H-CC, 10H-CC, and $11 \mathrm{H}-\mathrm{CC}$. The lowermost sample is assigned an age of $2.38 \mathrm{Ma}$ based on nannofossil and planktonic foraminifer events from this hole.

Low radiolarian abundance and the generally poor state of preservation at this site precludes recognition of any biostratigraphic marker species used in the low-latitude radiolarian biostratigraphic scheme. Offset cores drilled in the four holes indicate that within short distances there are great differences in opal content. We expect to recover opal-rich intervals containing well-preserved, rich radiolarian faunas between core catchers, similar to DSDP Site 609, where Haslett (1994) established a radiolarian biostratigraphy. Even though opal preservation was a problem and many marker species were missing, he was still able to recognize several low-latitude key marker species.

Interestingly, $C$. davisiana shows some peculiar occurrences. This species has an inconsistent distribution in Site U1313 holes. Its more or less consistent distribution in the upper part of the four holes is in fairly close agreement with observations by $\mathrm{S}$. Funakawa at Site U1308, where he found its FO in Sample 303-U1308A-20H-CC (see "Biostratigraphy" in the "Site U1308" chapter). This datum is assigned an age of 2.6 Ma. We have found C. davisiana in 14 core catcher samples below its anticipated FO at Site U1313. As reported by Motoyama (1997), morphotypic individuals of $C$. davisiana have been found back to $4.2 \mathrm{Ma}$ at DSDP Site 192 in the North Pacific.

The occurrence of $C$. davisiana at $2.6 \mathrm{Ma}$ (Motoyama, 1997) represents its first common and continuous stratigraphic distribution. If our recording of $C$. davisiana in the deeper parts of the sections is real and not a result of downhole reworking, we conclude that its oldest occurrence is in Sample 306-U1313B$29 \mathrm{H}-\mathrm{CC}$, or at $\sim 6 \mathrm{Ma}$ (LO of $A$. amplificus). Even if Motoyama (1997) convincingly demonstrated that C. davisiana evolved from Cycladophora sakaii, our findings imply C. davisiana occurs $\sim 2$ m.y. earlier in the North Atlantic than the North Pacific. This discrepancy will be addressed during our shore-based studies.

\section{Paleomagnetism}

Archive halves of all cores recovered at Site U1313 were measured on the three-axis cryogenic magnetometer at $5 \mathrm{~cm}$ intervals. The natural remanent magnetization (NRM) was measured before (NRM step) and after stepwise alternating-field (AF) demagnetization in peak fields of up to $20 \mathrm{mT}$. Cores 306U1313A-1H through $15 \mathrm{H}$ and $306-\mathrm{U} 1313 \mathrm{~B}-1 \mathrm{H}$ were AF demagnetized at peak fields of 10 and $20 \mathrm{mT}$. All the other cores were AF demagnetized at a peak field of $20 \mathrm{mT}$ to increase core flow through the laboratory.

Downcore variations in magnetic intensity in Holes U1313A through U1313D are shown in Figure F18. Data associated with intervals identified as physically disturbed were removed. NRM intensities after $20 \mathrm{mT}$ AF demagnetization are in the range of $10^{-3}$ to $10^{-4} \mathrm{~A} / \mathrm{m}$ above $150 \mathrm{mbsf}$ and drop by an order of magnitude (in the range of $10^{-5} \mathrm{~A} / \mathrm{m}$ ) in the lower part of the section. Inclination and declination data (after $20 \mathrm{mT}$ AF demagnetization) are shown in Figure F19. Declination values have been corrected using Tensor tool data, which were available starting with Cores 306-U1313A-3H, 306-U1313B-3H, 306U1313C-4H, and 306-U1313D-3H. The Tensor tool was not used in Cores 306-U1313B-31H and 32H. All four holes display similar directional changes to $\sim 250$ mbsf.

The distribution of inclination values at Site U1313, after AF demagnetization at $20 \mathrm{mT}$, is composed of two log-normal distributions centered at $-52^{\circ}$ and $+63^{\circ}$. These values are close to the expected site values for a geocentric axial dipole $\left(\mathrm{I}_{\mathrm{GAD}}= \pm 60.1^{\circ}\right)$. These results indicate that most of the drill string overprint was removed at $20 \mathrm{mT}$, although a small overprint 
may remain in some intervals as the distributions are slightly offset toward more positive values.

The magnetostratigraphy was constructed based on the succession of polarity reversals recorded at Site U1313 (Fig. F20). The Brunhes/Matuyama reversal occurs at $34.2 \pm 0.4$ mbsf in Hole U1313A, $34.1 \pm 0.4$ mbsf in Hole U1313B, $34.1 \pm 0.4$ mbsf in Hole U1313C, and $33.8 \pm 0.1 \mathrm{mbsf}$ in Hole U1313D. A detailed list of the occurrence depths of the polarity transitions identified at Site U1313 and their possible correlation to the geomagnetic polarity timescale (Cande and Kent, 1995) is provided in Table T24. Overall, the Jaramillo and Olduvai Subchrons are well recorded in these sediments, along with shorter geomagnetic events such as Cobb Mountain and Reunion. In the region below 150 mbsf $(\sim 167$ meters composite depth [mcd]), the inclination signal is noisier due to lower NRM intensity values. It is, however, possible to observe alternating intervals of normal and reversed polarities, which are consistent from one hole to the other. The resulting magnetostratigraphy can be correlated to the geomagnetic polarity timescale with good confidence to $\sim 220$ mbsf ( $246 \mathrm{mcd})$ and is consistent with biostratigraphy (see "Biostratigraphy").

In the underlying sediment, however, the link to the biostratigraphy-based age model is not straightforward. The polarity within this interval is assumed to be reversed between 222.3 and 239.2 mbsf in Hole U1313A then normal between 239.2 and $249.7 \mathrm{mbsf}$ (262.4 and $277.1 \mathrm{mcd}$ ). The magnetostratigraphy is uncertain below this depth, as it varies from one hole to the other. In particular, it is difficult to assess whether the polarity is normal or reversed at the bottom of the section. A possible explanation for the observed discrepancies is that alloy steel core barrels, which might induce a stronger drill string overprint, were used instead of the nonmagnetic core barrels in Cores 306-U1313A-32H and 33H and 306-U1313C$31 \mathrm{H}$ and $32 \mathrm{H}$. If we assume that the sediment recovered in Hole U1313B carries the most reliable signal, then the polarity below $\sim 250$ mbsf $(\sim 277 \mathrm{mcd})$ is reversed.

Given the noise level of the data, there are two possible ties to the global geomagnetic timescale, which are illustrated in Figure F20. A first possibility is to identify the normal polarity interval between 239.2 and 249.7 mbsf as Chron C3An (including both Subchrons C3An.1n and C3An.2n), whereas the second possibility is to identify it as Subchron C3An.1n only. In the first case, the base of this normal polarity interval would be dated at $6.56 \mathrm{Ma}$, whereas in the second case it would be dated at 6.137 Ma (Fig. F20). The second case provides an age model that is more consistent with the one based on biostratigra- phy but requires a large increase in sedimentation rates at $\sim 250 \mathrm{mbsf}(\sim 277 \mathrm{mcd})$, as the next polarity reversal is not present in the section.

\section{Stratigraphic correlation}

The four holes cored at Site U1313 provided ample sediment for constructing one complete spliced stratigraphic section and a second nearly complete section. The first spliced section was built from Holes U1313B and U1313C, and the second from Holes U1313A and U1313D. Because Hole U1313D only extends down to $159.3 \mathrm{mbsf}$, this second splice contains core recovery gaps between the cores from Hole U1313A from $~ 174$ to $334 \mathrm{mcd}$. Correlation between holes is very poor below $250 \mathrm{mcd}$, and so the completeness of both spliced sections is uncertain in that interval. Correlation between holes was excellent in lithologic Unit I (0-168.5 mcd) because of the cyclic alternations in the lithology, which is largely controlled by variations in the amount of clay (Figs. F21, F22, F23). The alternations produce variations in nearly all physical properties measured. In particular, the lightness $\left(\mathrm{L}^{*}\right)$ from color reflectance measurements mimic variations in the global benthic oxygen isotope stack of Lisiecki and Raymo (2005), indicating that the darker, more clay rich sediments are associated with glacials and the lighter, more carbonate rich sediments are associated with interglacials. The correlation is even more striking than what was observed for Site U1312.

Between-hole correlation is difficult in lithologic Unit II (168.5-334 mcd) because the sediments are fairly homogeneous calcareous nannofossil ooze. Cyclic variations are evident in some of the physical properties in this unit, but the amplitude of these variations are very small and the wavelength short (less than a few meters). For example, the cyclic alternations are associated with $\mathrm{L}^{*}$ variations of $>20 \%$ in Unit I, whereas the variations are only $\sim 5 \%$ or less for most of Unit II. For Unit II, these coherent L* variations are also somewhat obscured by spikes associated with dark iron sulfide patches and streaks that are common along the split-core surface.

\section{MSCL measurements and adjustments to coring operations}

As at Site U1312, we measured the susceptibility of whole-core sections with the "Fast Track" magnetic susceptibility core logger (MSCL) as soon as possible after recovery. Below $\sim 125 \mathrm{mcd}$, magnetic susceptibility decreased to noise level of the Bartington susceptibility meter because of the high carbonate content of the sediments. Therefore, we focused our 
measurements on only the uppermost 16-19 cores for each hole.

Initial correlation based on these data was used to monitor the coring breaks and ensure that they did not coincide for any two holes. During coring, Hole U1313B was only offset vertically such that each core would be $\sim 2$ m deeper than that from Hole U1313A. This offset was mostly successful at filling the coring gaps from Hole U1313A, but by a very narrow margin. Based on our correlation of the MSCL data, the intended $2 \mathrm{~m}$ offset was only $\sim 1.5 \mathrm{~m}$ at the top of Hole U1313B and became narrower with depth. A decision was made to increase the offset after Core 306-U1313B-20H by drilling ahead $2 \mathrm{~m}$. This was the only adjustment made to coring based on correlation.

\section{Meters composite depth scale and spliced stratigraphic sections}

The final mcd scale (Table T25) and two spliced stratigraphic sections (Tables T26, T27) were constructed after GRA density, natural gamma radiation (NGR), magnetic susceptibility, magnetic intensity and inclination, and color reflectance data became available. As is typical of mcd scales, the Site U1313 mcd scale is expanded by $\sim 10 \%-12 \%$ relative to the mbsf scale. Prior to uploading the data into Splicer for correlation, we removed those intervals that contained coring disturbance or voids (Table T28). Each of these cleaned data sets contains distinct variations useful for correlation.

In lithologic Unit I, we relied mainly on the many distinctive $L^{*}$ and magnetic susceptibility variations as well as geomagnetic polarity reversals recorded in the paleomagnetic inclination (Table T24). Correlation was straightforward, the mcd scale is well resolved, and both spliced sections are complete over this entire interval (Figs. F21, F22, F23).

Because correlation was more difficult in Unit II, we used whichever data set had distinctive correlative features, as no one data set was sufficient. In this interval, the inclination data and three turbidite beds (Table T2) provided the most useful, albeit rather coarse, features for correlation. Below Chronozone $3 \mathrm{n} .4 \mathrm{n}$ (Thvera) at $\sim 250 \mathrm{mcd}$, virtually no feature can be confidently correlated. Thus, below $250 \mathrm{mcd}$, the composite depth scale and the spliced sections are little more than best guesses.

\section{Age model based on correlation of lightness to marine isotopic stages}

A preliminary age model was constructed by tuning the Site U1313 $\mathrm{L}^{*}$ splice to the LR04 benthic isotope stack (Lisiecki and Raymo, 2005). For the correlation
(Fig. F24), sharp color changes as characterized by $\mathrm{L}^{*}$ variations were tied with glacial and interglacial terminations (benthic isotope maxima). These tie points are given in Table T29. Back to 3.4 Ma every isotope stage listed by Lisiecki and Raymo (2005) could be identified in the color record and tuning was straightforward. The resulting timescale (Fig. F24C, F24E) is in excellent agreement with stage boundaries and events found in magnetostratigraphy (Fig. F24B). Based on the age model and mcd depths, the sedimentation rate at Site U1313 for the last $3.4 \mathrm{~m} . y$. averages $4.8 \mathrm{~cm} / \mathrm{k} . \mathrm{y}$. and varies between 3 and $7.5 \mathrm{~cm} /$ k.y. (Fig. F24D, F24F). Higher sedimentation rates were found for glacial intervals.

\section{Geochemistry}

\section{Inorganic geochemistry}

\section{Interstitial water chemistry}

A total of eight interstitial water samples were extracted from $5 \mathrm{~cm}$ whole-round sediment sections from Hole U1313A with a resolution of one sample per core for the first six cores and thereafter one sample per core for Cores 306-U1313A-9H and $12 \mathrm{H}$, covering a depth of 106.2 mbsf. Interstitial water samples were processed for routine shipboard geochemical analyses (see "Geochemistry" in the "Site U1312-U1315 methods" chapter). The concentrations of dissolved elements from Hole U1313A are given in Table T30, and their downhole profiles are illustrated in Figure F25. In comparison to Hole U1312A, none of the sediments used for interstitial water sampling in the upper section of Hole U1313A were physically disturbed or influenced by flow-in (see "Stratigraphic correlation;" Table T28). A noticeable change in the parameters of most pore water profiles is observed below $77.6 \mathrm{mbsf}$ depth.

\section{Chlorinity, salinity, alkalinity, and $\mathrm{pH}$}

Chloride $\left(\mathrm{Cl}^{-}\right)$concentrations in Hole U1313A increase from $568 \mathrm{mM}$ at $3 \mathrm{mbsf}$ to $\sim 572 \mathrm{mM}$ at 77.6 mbsf, except for a low value of $559 \mathrm{mM}$ at $30.2 \mathrm{mbsf}$. Below 77.6 mbsf, chlorinity decreases to a depth of $106.2 \mathrm{mbsf}$, where a value of $\sim 554 \mathrm{mM}$ is measured (Fig. F25A).

Downhole salinity increases from 33 to $35 \mathrm{~g} / \mathrm{kg}$ between 3 and 20.7 mbsf. It then decreases to $34 \mathrm{~g} / \mathrm{kg}$ between 20.7 and $30.2 \mathrm{mbsf}$, remains uniform to $77.6 \mathrm{mbsf}$, and then further decreases to $33 \mathrm{~g} / \mathrm{kg}$ to the bottom of the profile (Fig. F25B).

Alkalinity increases with depth from 3.52 to 6.07 $\mathrm{mM}$ between 3.0 and $106.2 \mathrm{mbsf}$ (Fig. F25C). These values are similar to those reported from Hole 
U1308A (see the "Site U1308" chapter) but higher than those reported from Hole U1312A.

$\mathrm{pH}$ values in Hole U1313A range from 7.20 to 7.39, which is similar to the values in Hole U1312A, albeit more variability is observed between 11.2 and 47.8 mbsf (Fig. F25D).

\section{Sodium, potassium, magnesium, and calcium}

Sodium $\left(\mathrm{Na}^{+}\right)$, potassium $\left(\mathrm{K}^{+}\right)$, and magnesium $\left(\mathrm{Mg}^{2+}\right)$ concentrations in the interstitial water of Hole U1313A range from $\sim 418$ to $\sim 494.3 \mathrm{mM}, 10.9$ to 12.4 $\mathrm{mM}$, and 46.1 to $51.8 \mathrm{mM}$, respectively. Their downhole profiles show trends that are roughly similar to each other except for an increase in $\mathrm{Mg}^{2+}(49.8 \mathrm{mM})$ at 20.7 mbsf (Fig. F25E). $\mathrm{Ca}^{2+}$ values range from 8.9 to $10.1 \mathrm{mM}$ throughout the profile.

\section{Iron, boron, barium, lithium, manganese, and strontium}

Iron $\left(\mathrm{Fe}^{2+}\right.$ ) concentrations in Hole U1313A could be divided into two parts: a sharp downhole decreasing trend from $\sim 16$ to $1.9 \mu \mathrm{M}$ between 3 and $20.7 \mathrm{mbsf}$ and a moderate downhole increasing trend between 20.7 and 106.5 mbsf (Fig. F25I). The lowest value of $1.9 \mu \mathrm{M}$ is measured within the lithologic interval displaying darker and black streaks, suggesting the presence of diagenetic iron minerals.

Boron (B) concentrations, mostly as boric acid $\left(\mathrm{H}_{3} \mathrm{BO}_{3}\right)$ in the interstitial water samples of Hole U1313A, are highly variable and range from $\sim 448$ to $509 \mu \mathrm{M}$ (Fig. F25J). Barium $\left(\mathrm{Ba}^{2+}\right)$ concentrations in Hole U1313A are relatively uniform, ranging from 3.12 to $3.20 \mu \mathrm{M}$, and are nearly three times higher than those measured in Hole U1312A.

The lithium $\left(\mathrm{Li}^{+}\right)$and strontium $\left(\mathrm{Sr}^{2+}\right)$ profiles show opposite trends to each other. Lithium $\left(\mathrm{Li}^{+}\right)$concentrations exhibit a linear decrease with depth, whereas strontium $\left(\mathrm{Sr}^{2+}\right)$ concentrations increase downcore (Fig. F25L, F25N). These trends can be explained by the utilization of $\mathrm{Li}^{+}$during transformation of ash fragments into clay minerals and by the expulsion of $\mathrm{Sr}^{2+}$ from the carbonate constituents in the sediments during dissolution and reprecipitation into the pore water (Baker et al., 1982; De Carlo, 1992). Manganese $\left(\mathrm{Mn}^{2+}\right)$ concentrations are also higher in the shallowest samples $(\sim 45 \mu \mathrm{M})$, but they decrease rapidly at a depth of 20.7 mbsf and remain low through the rest of the downhole profile (Fig. F25M).

\section{Dissolved silica, sulfate, and ammonium}

The dissolved silica $\left(\mathrm{H}_{4} \mathrm{SiO}_{4}\right)$ profile can be divided into two parts: the upper portion shows a downhole increasing trend to $39.3 \mathrm{mbsf}$, whereas the lower portion exhibits a decreasing trend from $39.3 \mathrm{mbsf}$ to the bottom of the profile (Fig. F25O). The highest dissolved silica concentration was measured at 39.3 mbsf and likely reflects the initial presence of biogenic silica in the sediments and its subsequent dissolution.

Sulfate $\left(\mathrm{SO}_{4}{ }^{2-}\right)$ concentrations show a slightly decreasing downhole trend (Fig. F25P).

Ammonium $\left(\mathrm{NH}_{4}{ }^{+}\right)$concentrations increase downcore and exhibit the highest values $(615 \mu \mathrm{M})$ at 47.8 mbsf (Fig. F25P). It is usually suggested that the diagenesis of organic matter depletes the dissolved $\mathrm{SO}_{4}{ }^{2-}$ by sulfate reduction reaction, which can be shown as follows:

$$
\begin{gathered}
\left(\mathrm{SO}_{4}{ }^{2-}+\mathrm{C}_{106} \mathrm{O}_{110} \mathrm{~N}_{16} \mathrm{P}\right) /\left(\mathrm{CO}_{2}+\mathrm{HCO}_{3}{ }^{-}+\right. \\
\left.\mathrm{NH}_{4}{ }^{+}+\mathrm{HS}^{-}+\mathrm{H}_{2} \mathrm{O}+\mathrm{HPO}_{4}{ }^{2-}\right) .
\end{gathered}
$$

Sulfate concentrations are near seawater values at the top of the section and do not decrease downcore, significantly suggesting that the sulfate reduction process is not complete (Fig. F25P). As can be seen in Figure F25, sulfate concentrations decrease while those of $\mathrm{NH}_{4}{ }^{+}$increase. Moreover, as stated above, alkalinity increases downhole, similar to the increases in downhole $\mathrm{NH}_{4}{ }^{+}$values, are consistent with the prevalent reductive process. This is concordant with the relatively low methane $\left(C_{1}\right)$ in headspace samples (Table T31). Note that the available HS- can react with $\mathrm{Fe}^{2+}$ to form iron sulfide minerals (e.g., FeS and $\mathrm{FeS}_{2}$ ), attesting the presence of dark and black pyritic substances (see "Lithostratigraphy").

\section{Organic geochemistry}

\section{Volatile hydrocarbons}

Headspace gas analysis was conducted as part of the standard protocol required for shipboard safety and pollution prevention monitoring. A total of 32 headspace samples from Hole U1313A, with a sample resolution of one sample per core, were analyzed (Table T31). Methane was the only hydrocarbon gas detected at the site. The concentrations of $\mathrm{CH}_{4}$ in Hole $\mathrm{U} 1313 \mathrm{~A}$ are relatively constant and range from 1.5 to 2.4 ppmv (Fig. F26). The average methane concentration in Hole U1313A is 1.8 ppmv, slightly below the background level.

\section{Sedimentary bulk geochemistry}

Sediment samples for the analysis of solid-phase bulk inorganic carbon, total carbon, and total nitrogen (TN) were collected from the working halves from Hole U1313A at a resolution of two samples per core. In addition, splits of squeeze cakes from interstitial water samples intended for investigations of solventextractable organic matter (see below) were also used for bulk measurements. Data from the bulk geochemical analysis performed on a total number 
of 75 samples are shown in Table T32 (see "Geochemistry" in the "Site U1312-U1315 methods" chapter for analytical methods and the derivation of total organic carbon [TOC] values).

Downhole variations of calcium carbonate contents along with the lightness $\left(\mathrm{L}^{*}\right)$ data from Hole U1313A are shown in Figure F27. For comparison, the calcium carbonate profile from DSDP Site 607 (Ruddiman, Kidd, Thomas, et al., 1987) is also plotted in Figure F27.

$\mathrm{CaCO}_{3}$ contents in Hole U1313A range from 31.5 to $96.7 \mathrm{wt} \%$ (average $=80.5 \mathrm{wt} \%$ ). The most obvious change in the carbonate distribution in Hole $\mathrm{U} 1313 \mathrm{~A}$ is found at $\sim 120 \mathrm{mbsf} . \mathrm{CaCO}_{3}$ contents are relatively constant at $>90 \mathrm{wt} \%$ below this depth, whereas they are highly variable between 0 and $\sim 120$ mbsf. High-amplitude fluctuations in $\mathrm{CaCO}_{3}$ contents from $\sim 30$ to $90 \mathrm{wt} \%$ are characteristic of the upper $\sim 40 \mathrm{mbsf}$ (average $=60 \mathrm{wt} \%$ ). Between $\sim 40$ and 120 mbsf, a $\sim 10 \%$ reduction in the amplitude and $\mathrm{CaCO}_{3}$ values from $\sim 40$ to $\sim 90 \mathrm{wt} \%$ are observed. A shift toward higher (69 wt\%) average carbonate content compared to the top $40 \mathrm{mbsf}$ is also noted.

Low-amplitude variability ( 5\%-10\%) between 120 mbsf and the bottom of the profile is observed where the carbonate content is constantly high (average $=$ $94 \mathrm{wt} \%)$. Color reflectance $\left(\mathrm{L}^{*}\right)$ data display a similar general trend as the carbonate profile and further reveal that the oscillation pattern is in fact preserved at much higher frequencies at Site U1313 (e.g., L* versus global $\delta^{18} \mathrm{O}$ stack) (see also "Stratigraphic correlation"), as known from the $\mathrm{CaCO}_{3}$ record at Site 607 (Ruddiman, Kidd, Thomas, et al., 1987) (Fig. F27).

TOC and TN contents range from 0 to $0.65 \mathrm{wt} \%$ and 0.05 to $0.23 \mathrm{wt} \%$, respectively, in sediments of Hole U1313A (Fig. F28). Both TOC and TN average 0.1 wt $\%$. Despite overall low mean TOC contents, the upper $\sim 170 \mathrm{~m}$ generally show higher variability with higher-amplitude fluctuations (0.05-0.6 wt\%) between $\sim 20$ and 70 mbsf and less variation from $\sim 70$ to 170 mbsf. Below 170 mbsf, the TOC contents remain uniformly low $(<0.1 \mathrm{wt} \%)$.

TN concentrations are low overall and relatively uniform.Variations in amplitude are in the order of $0.05 \%$. However, a decrease in $\mathrm{TN}$ from $\sim 0.15$ to 0.1 wt $\%$ between 0 and $\sim 150$ mbsf is notable, which is comparable to the TN profile at Hole U1312A. At Site U1313, TN versus depth also seems to roughly mimic the downhole clay content as obtained by the smear slide estimates (see "Description of units"). Because clay minerals tend to absorb ammonium ions (Müller, 1977) and most of the samples contain rela- tively low TOC $(<0.2 \mathrm{wt} \%)$, TOC/TN ratios are not useful to distinguish between marine and terrestrial organic matter.

\section{Extractable organic matter and sources}

In Hole U1313A, 16 samples were used for investigation of the solvent-extractable matter (Table T33). Unfortunately, the gas chromatography/mass spectrometry system could not be used at this site. However, using a flame ionization detector (FID) instead of the mass spectrometer allowed us to obtain a visual overview of the extractable compound inventory as well as to identify its major constituents (see "Geochemistry" in the "Site U1312-U1315 methods" chapter). As an example, the compound distribution of Sample 306-U1313A-5H-4, 145-150 cm, is shown in Figure F29. Two compound classes constitute the majority of the organic matter fraction, namely (1) a series of $n$-alkanes in a carbon atom number range of $\sim \mathrm{C}_{20}-\mathrm{C}_{33}$ with a notable preference to long-chain $\left(>\mathrm{C}_{25}\right)$ odd-numbered compounds and (2) homologs of $\mathrm{C}_{37}-\mathrm{C}_{39}$ unsaturated methyl and ethyl ketones (alkenones).

1. The $n$-alkanes derived from cuticular waxes of higher land plants typically range from $\mathrm{C}_{23}$ to $\mathrm{C}_{35}$ with a distinct dominance of odd carbon chain lengths and a maximum concentration at $\mathrm{C}_{27}, \mathrm{C}_{29}$, and $\mathrm{C}_{31}$ (Eglinton et al., 1962; Eglinton and Hamilton, 1967; Rieley et al., 1991; Kunst and Samuels, 2003). The carbon preference index (CPI) (e.g., Bray and Evans, 1961) is an expression of this oddnumbered $n$-alkane predominance, and $n$-alkane mixtures from natural vegetation waxes have high CPI (>5) (e.g., Eglinton and Hamilton, 1963). Similarly, $n$-alkanes in marine sediments showing a pronounced preference of long-chain $\left(>\mathrm{C}_{25}\right)$ oddnumbered homologs (and high CPI) are interpreted to be of terrigenous origin. Thus, the identification of long-chain $n$-alkanes with high CPIs of 2.0-4.7 (Table T33) in the sediments of Hole U1313A suggests that these compounds were derived from terrigenous sources.

2. Alkenones are only biosynthesized by a few extant species of haptophyte algae, primarily E. huxleyi and Gephyrocapsa spp. (see review in Conte et al., 1994; Volkman, 2000). Therefore, the presence of these compounds in the sediments of Site U1313 indicates that certain portions of the organic matter are also derived from a marine source.

As a first proxy to estimate marine and terrigenous organic matter contributions in the sediments of Hole U1313A, the ratio of plant wax-derived $n$ alkanes and haptophyte-derived alkenones can be used. A similar approach has also been used to characterize the organic matter deposited in the North 
Atlantic during the last climatic cycle (Villanueva et al., 1997). Figure F30 shows the downcore variations in the proportions of terrigenous and marine organic matter calculated as a normalized percentage from the summed peak areas of $\mathrm{C}_{27}, \mathrm{C}_{29}$, and $\mathrm{C}_{31} n$-alkanes and $\mathrm{C}_{37}$ alkenones, respectively. A wide range of variability is observed in the composition of the organic matter, although it is based on a limited number of samples. Marine-derived organic matter composes between $\sim 20 \%$ and $80 \%$, whereas the remaining portion is of a terrigenous source. It may be mentioned here, however, that this approach does not consider amounts of marine organic matter potentially derived from diatoms, which partly occur in significant abundances in sediments of Site U1313 (see "Biostratigraphy").

\section{Alkenone-derived sea-surface temperatures}

Besides indicating marine-derived sedimentary organic matter contributions, alkenones have also been widely used in paleoceanography for assessing the past sea-surface temperature (SST) changes because there exists a strong relationship between the degree of alkenone unsaturation and growth temperature. This degree of unsaturation can be evaluated from the abundance of the dominant di- and triunsaturated $\mathrm{C}_{37}$ alkenones, commonly referred to as the $\mathrm{Uk}^{\prime}{ }_{37}$ index:

$$
\mathrm{Uk}^{\mathrm{k}_{37}}=\left[\mathrm{C}_{37: 2}\right] /\left(\left[\mathrm{C}_{37: 2}\right]+\left[\mathrm{C}_{37: 3}\right]\right) \text {. }
$$

The initial $\mathrm{Uk}^{\prime}{ }_{37}$ growth temperature calibration derived from a culture of $E$. huxleyi shows a simple but clear linear relationship between $\mathrm{Uk}^{\mathrm{k}_{37}}$ and temperature in a range of $5^{\circ}-25^{\circ} \mathrm{C}$ (Prahl and Wakeham, 1987; Prahl et al., 1988):

$$
\mathrm{U}^{\mathrm{k}^{\prime}}{ }_{37}=0.034(\mathrm{SST})+0.039 \text {. }
$$

Notably, equation 3 is statistically identical to a regression between $\mathrm{U}^{\mathrm{k}_{37}}$ indexes determined in coretop sediments between $60^{\circ} \mathrm{N}$ and $60^{\circ} \mathrm{S}$ latitude $(n=$ 370) and ocean-atlas mean annual SSTs (Müller et al., 1998). Equation 3 was used to calculate alkenone-derived SSTs at Site U1313 $\left(41^{\circ} \mathrm{N}\right)$.

In Hole U1313A, SST ranges from $12.7^{\circ}$ to $22.1^{\circ} \mathrm{C}$ (Table T33). Pleistocene SSTs $(n=11)$ display a high overall variability between $12.7^{\circ}$ and $18.7^{\circ} \mathrm{C}$. Notably, the $6^{\circ} \mathrm{C}$ variability as well as the absolute temperatures calculated from alkenones at Site U1313 match almost perfectly with the difference between the modern SSTs $\left(\sim 16^{\circ}-18^{\circ} \mathrm{C}\right)$ (Fig. F5) and the reduced LGM SSTs $\left(\sim 10^{\circ}-12^{\circ} \mathrm{C}\right)$ obtained by foraminiferal transfer functions for the relevant area of the North Atlantic by Pflaumann et al. (2003). Pliocene SSTs are significantly higher $\left(16.8^{\circ}-21.6^{\circ} \mathrm{C} ; n=4\right)$ and a maximum SST of $22.1^{\circ} \mathrm{C}$ is obtained for one sample from the latest Miocene (306-U1313A-29H-6,
$70-72 \mathrm{~cm})$. As shipboard data already allowed the construction of an age model for Site U1313 (see "Stratigraphic correlation;" Table T29), PliocenePleistocene alkenone SSTs are compared to the global climate record based on benthic $\delta^{18} \mathrm{O}$ data (Lisiecki and Raymo, 2005). Figure F31 shows that alkenonederived SSTs from sediments of Hole U1313A are in excellent agreement with glacial-interglacial cycles in terms of the recorded amplitudes, the overall variability, and the Pliocene-Pleistocene climatic evolution. Although these results are based only on a very limited set of samples and the interpretation is still preliminary, the alkenone approach for estimating SSTs and their short- and long-term variability at Site U1313 in future research is very promising.

\section{Physical properties}

Physical properties of marine sediments are good indicators of composition, formation, microstructure, environmental conditions, and depositional processes. Physical properties are also important for correlating depths between holes. Marine sediment physical properties at Site U1313 were measured following the procedures described in "Physical properties" in the "Site U1312-U1315 methods" chapter. Magnetic susceptibilities were measured using both the MSCL and the multisensor track (MST) system. GRA densities, $P$-wave velocities, and NGR were also measured using the MST. Discrete $P$-wave velocities were measured ( $P$-wave sensor number 3 -measuring perpendicular to the core axis) on each section. Finally, moisture and density were measured on two discrete samples per core, usually at the bottom of the first and sixth sections.

\section{Whole-core magnetic susceptibility measurements}

Magnetic susceptibility measurements measured on the MSCL and with the MST generally show similar trends and display multiple excursions toward higher values in the upper section of all holes (Fig. F32). Magnetic susceptibility values at Site U1313 are highly variable in the upper $\sim 140 \mathrm{~m}$ because of variations in clay content. Below $140 \mathrm{~m}$, carbonate content exceeds $95 \mathrm{wt} \%$ and magnetic susceptibilities are very low. In the lower sections (below $\sim 140 \mathrm{~m}$ ) of Holes U1312A, U1313B, and U1313C, the values of the magnetic susceptibility measured by the MST show more coherent and negative values. Site U1313 has peak magnetic susceptibility values of $\sim 8 \times 10^{-3} \mathrm{SI}$ units and minimum values approaching the instrument noise level, with most values ranging from 0.4 $\times 10^{-3}$ to $1.6 \times 10^{-3}$ SI units. 


\section{Gamma ray attenuation density}

Sediments from Site U1313 show a general increase in bulk density with depth (Fig. F33), consistent with a downhole decrease in water content due to compaction. GRA density varies between 1.4 and 1.9 $\mathrm{g} / \mathrm{cm}^{3}$. Discrete bulk densities (Fig. F34) show similar increase with depth.

\section{Natural gamma radiation}

NGR counts range from 15 to $30 \mathrm{cps}$ in the upper $125 \mathrm{~m}$ of all sections as shown in Figure F35. Below $125 \mathrm{~m}$, the values are relatively stable and range from 12 to 14 cps, consistent with the high-carbonate fraction.

\section{Density and porosity}

Porosity measurements were calculated from discrete samples. Porosity decreases from $80 \%$ at the seafloor to $\sim 55 \%$ at 200 mbsf. Discrete dry density values increase downhole from $0.5 \mathrm{~g} / \mathrm{cm}^{3}$ to $1.2 \mathrm{~g} / \mathrm{cm}^{3}$ at 200 mbsf. The porosity pattern is consistent with compaction and shows an inverse relationship to density. Porosity and dry density values are shown in Figure F34.

\section{$P$-wave velocity}

$P$-wave velocities were measured for Holes U1313A and U1313B using the MST (Fig. F36). MST measurements of $P$-wave velocities were found to adversely affect magnetic susceptibility measurements, so $P$ wave velocities were not measured on subsequent holes. Additionally, discrete measurements of $P$-wave velocity were made on each section of Hole U1313A. In general, the measurements of $P$-wave velocity vary between 1500 and $1600 \mathrm{~m} / \mathrm{s}$ and increase downhole. Trends in $P$-wave velocity are in general correlated with trends in density.

\section{Discussion}

The physical properties measured at Site U1313 are generally well correlated and show the greatest variability in the upper $140 \mathrm{~m}$, consistent with greater variability in clay content. This variability in clay content is thought to reflect glacial-interglacial changes, with clay content being highest during glacial times. Below 140 mbsf, the carbonate content exceeds $95 \mathrm{wt} \%$ and the variability in physical properties is small.

\section{Downhole measurements}

\section{Logging operations}

Downhole logging operations were carried out after coring Hole U1313B to a depth of 302 mbsf (3727 mbrf) and displacing with sepiolite mud (see "Operations"). The drill pipe was raised to $65.3 \mathrm{mbsf}$ (3489.6 mbrf) prior to logging. During logging operations, the sea state was fairly calm with a typical heave of $2 \mathrm{~m}$ or less. The LDEO-Borehole Research Group wireline heave compensator (WHC) was used throughout the logging operations in the open hole.

The initial plan was to use two tool string configurations, the triple combo with an additional MGT and the FMS-sonic tool string (see "Downhole measurements" in the "Site U1312-U1315 methods" chapter). However, shortly after deploying the triple combo-MGT tool string, power problems forced us to bring the tool string back on deck for examination. It was determined that the MGT tool was leaking and had caused damage to the telemetry cartridge below. The MGT was removed from the tool string and a new telemetry cartridge was installed on the tool string. Following the repairs, the triple combo was deployed successfully to the bottom of the borehole at 300 mbsf (3725.3 mbrf). Details of the intervals logged, together with the position of the drill bit, are shown in Figure F37.

Based on the very low amplitude resistivity results from the triple combo and the delays caused by earlier tool problems, it was decided not to deploy the FMS-sonic tool string. The second pass of the triple combo tool string was used to fully test new software for the new Schlumberger WHC system. These tests provided important performance information and showed promising results.

\section{Data quality}

Initial examination of the logging data from the triple combo tool string showed good quality data for several logs including natural gamma radiation, density, and porosity. This is supported by the caliper data, which show that the diameter of the borehole (drill bit size $=11.4$ inches) ranged over just a few inches from $\sim 10.6$ to 15.5 inches over the entire interval (Fig. F38). The density and porosity tools require good borehole contact and are held against the borehole wall by an eccentralizer that is only effective in the open borehole below the drill pipe. Density and porosity data are also less reliable when the caliper has been closed before the tool string enters the base of the drill pipe (i.e., above 75 mbsf during the main pass) (Fig. F38). Resistivity data from the formation are quite consistent between shallow spherically focused resistivity, intermediate medium induction phasor-processed resistivity, and deep induction phasor-processed resistivity, despite their low amplitude, indicating that the tool is getting reliable results. The gamma ray results are also very 
consistent and can be evaluated even through the drill pipe, despite some attenuation of the signal.

\section{Results}

The downhole logging data suggest that the formation is made up of two main sections that can be delineated at a depth of $\sim 150$ mbsf in almost every downhole log. This boundary shows up especially well in the gamma and resistivity data and is driven by increasing clay content in the sediments beginning at $\sim 150$ mbsf. This boundary is also seen clearly in core physical properties like magnetic susceptibility, lightness ( $\mathrm{L}^{*}$ values), and NRM paleomagnetic intensities. Visual core descriptions show that this boundary is gradational between 120 and 150 mbsf.

As is usual, the density and porosity logs are generally inversely related and show downhole trends of increasing density $\left(1.6 \mathrm{~g} / \mathrm{cm}^{3}\right.$ at $80 \mathrm{mbsf}$ to $1.9 \mathrm{~g} / \mathrm{cm}^{3}$ at $300 \mathrm{mbsf})$ and decreasing porosity ( 75\% at 80 mbsf to $\sim 50 \%$ at $300 \mathrm{mbsf}$ ) due to compaction. Resistivity values are low $(\sim 0.8-1.1 \Omega \mathrm{m})$ reflecting the generally moderate- to high-porosity sediments. However, there are two significant changes in resistivity patterns downcore. The first one is at $150 \mathrm{mbsf}$ and corresponds to the major change in lithologies noted above. The second is at $240 \mathrm{mbsf}$ and may correspond to a significant change in grain size. Photoelectric effect factor values increase from $3.0 \mathrm{~b} / \mathrm{e}^{-}$ (clay rich) in the upper $150 \mathrm{~m}$ to as high as $4.5 \mathrm{~b} / \mathrm{e}^{-}$ (calcite rich) in the lower $150 \mathrm{~m}$, consistent with the lithologies (see "Lithostratigraphy").

Gamma ray values from the total spectral gamma ray (HSGR) $\log$ vary between 7 and 25 gAPI throughout the upper $150 \mathrm{mbsf}$, as they vary consistently with glacial-interglacial changes in clay content (Fig. F39). The values measured through the drill pipe in the upper $65 \mathrm{~m} \mathrm{(2-5} \mathrm{gAPI)} \mathrm{are} \mathrm{lower} \mathrm{but} \mathrm{are} \mathrm{attenu-}$ ated by a factor of $\sim 4-5$. Below $150 \mathrm{mbsf}$, gamma radiation decreases to values between 5 and $8 \mathrm{gAPI}$ as a result of decreasing clay content. The cycles seen in the upper part continue in the lower section but with reduced amplitude.

The gamma ray value is driven by the Th concentrations (1-3 ppm) derived from clay content. The relatively low $\mathrm{U}(<0.5 \mathrm{ppm})$ and $\mathrm{K}$ content $(<0.05 \mathrm{wt} \%)$ of the formation results in very similar HSGR and computed gamma ray headspace (HCGR; summation of Th and $\mathrm{K}$ gamma rays only) values. The $\mathrm{U}$ data suggest that total organic carbon values in the logged interval are consistently very low, as shown by discrete samples (see "Geochemistry"). Th, U, and $\mathrm{K}$ display very similar trends downhole that are consistent with major lithology changes. One observation seen downhole is the consistent pattern of $U$ and $\mathrm{Th}$ in the upper $150 \mathrm{~m}$ and out-of-phase behavior below 150 mbsf (Fig. F39).

\section{Core-logging comparisons}

The downhole data display consistent cyclic decimeter- to meter-scale variations that are the result of changes in lithology. A comparison of logging- and core-derived density, natural gamma radiation, and porosity (not shown) records show very good agreement in downhole trends and patterns (Fig. F40). Measured density values range from 1.6 to $1.85 \mathrm{~g} /$ $\mathrm{cm}^{3}$ in both core and logging data. Although scaled differently (cores in total counts per second and logs in gAPI), the gamma ray data suggests that $1 \mathrm{~m}$ or even smaller-scale patterns can be recognized in both the core and logging records (Fig. F40).

In Figure F41, two comparisons of the logging gamma ray, core gamma ray, and $\mathrm{L}^{*}$ values in the upper 70 mbsf of Hole U1313B are shown to demonstrate the remarkable degree of correlation possible between core and logging records. Even as amplitude of cycles decreases downcore, correlating these records with logging as a depth reference will be possible at meter (at least) scale to more precisely determine the amount of core expansion in the spliced core record.

Based on preliminary results of biostratigraphy and paleomagnetism, the estimated sedimentation rate determined from the age model for the last $5.4 \mathrm{~m} . \mathrm{y}$. is remarkably constant at $\sim 4 \mathrm{~cm} / \mathrm{k}$.y. To show how logging data can be used at this site for constraining age-depth models in detail, a simple linear plot of the gamma ray logging data over the interval from 0 to $225 \mathrm{mbsf}$ and the benthic oxygen isotope stack (Lisiecki and Raymo, 2005) was constructed for the last 5.4 m.y. (Fig. F42). The overall patterns of variability in both curves track each other quite well in a variety of frequencies over the whole record. This correlation has tie points at only the top and bottom ( 0 and $5.4 \mathrm{Ma}$ ) with no stretching or squeezing in between. This correlation is expanded over four time intervals (Fig. F43A, F43B, F43C, F43D) to highlight how faithfully the gamma ray profile tracks the oxygen isotope curve in rather amazing fashion despite large changes in signal amplitude. The predicted ages versus logging depth (mbsf) match the biostratigraphic and paleomagnetism datums very well over the last $5.4 \mathrm{~m} . \mathrm{y} .$, providing additional support for the extraordinarily constant sedimentation rates determined for this site.

\section{References}

Andersen, C., Koç, N., and Moros, M., 2004. A highly unstable Holocene climate in the subpolar North Atlan- 
tic: evidence from diatoms. Quat. Sci. Rev., 23:21552166. doi:10.1016/j.quascirev.2004.08.004

Backman, J., and Raffi, I., 1997. Calibration of Miocene nannofossil events to orbitally tuned cyclostratigraphies from Ceara Rise. In Shackleton, N.J., Curry, W.B., Richter, C., and Bralower, T.J. (Eds.), Proc. ODP, Sci. Results, 154: College Station, TX (Ocean Drilling Program), 83-99. [PDF]

Baker, P.A., Gieskes, J.M., and Elderfield, H., 1982. Diagenesis of carbonates in deep-sea sediments-evidence from $\mathrm{Sr}^{2+} / \mathrm{Ca}^{2+}$ ratios and interstitial dissolved $\mathrm{Sr}^{2+}$ data. J. Sediment. Petrol., 52:71-82.

Baldauf, J.G., 1987. Diatom biostratigraphy of the middleand high-latitude North Atlantic Ocean, Deep Sea Drilling Project Leg 94. In Ruddiman, W.F., Kidd, R.B., Thomas, E., et al., Init. Repts. DSDP, 94 (Pt. 2): Washington (U.S. Govt. Printing Office), 729-762.

Baldauf, J.G., Thomas, E., Clement, B., Takayama, T., Weaver, P.P.E., Backman, J., Jenkins, G., Mudie, P.J., and Westberg-Smith, M.J., 1987. Magnetostratigraphic and biostratigraphic synthesis, Deep Sea Drilling Project Leg 94. In Ruddiman, W.F., Kidd, R.B., Thomas, E., et al., Init. Repts. DSDP, 94 (Pt. 2): Washington (U.S. Govt. Printing Office), 1159-1205.

Bergen, J.A., 1984. Calcareous nannoplankton from Deep Sea Drilling Project Leg 78A: evidence for imbricate underthrusting at the Lesser Antillian active margin. In Biju-Duval, B., Moore, J.C., et al., Init. Repts. DSDP, 78 (Pt. 1): Washington (U.S. Govt. Printing Office), 411-445.

Berggren, W.A., 1972. Cenozoic biostratigraphy and paleobiogeography of the North Atlantic. In Laughton, A.S., Berggren, W.A., et al., Init. Repts. DSDP, 12: Washington (U.S. Govt. Printing Office), 965-1002.

Bond, G.C., Showers, W., Elliot, M., Evans, M., Lotti, R., Hajdas, I., Bonani, G., and Johnson, S., 1999a. The North Atlantic's 1-2 kyr climate rhythm: relation to Heinrich events, Dansgaard/Oeschger cycles and the Little Ice Age. In Clark, P.U., Webb, R.S., and Keigwin, L.D. (Eds.), Mechanisms of Global Climate Change at Millennial Time Scales. Geophys. Monogr., 112:35-58.

Bond, G., Showers, W., and Lynch-Stieglitz, J., 1999b. EOS, 80:S169.

Bray, E.E., and Evans, E.D., 1961. Distribution of $n$-paraffins as a clue to recognition of source beds. Geochim. Cosmochim. Acta, 22:2-15. doi:10.1016/00167037(61)90069-2

Calvo, E., Villanueva, J., Grimalt, J.O., Boelaert, A., and Labeyrie, L., 2001. New insights into the glacial latitudinal temperature gradients in the North Atlantic. Results from $\mathrm{U}^{\mathrm{k}^{\prime}}$ sea surface temperatures and terrigenous inputs. Earth Planet. Sci. Lett., 188:509-519. doi:10.1016/S0012-821X(01)00316-8

Cande, S.C., and Kent, D.V., 1995. Revised calibration of the geomagnetic polarity timescale for the Late Cretaceous and Cenozoic. J. Geophys. Res., 100:6093-6095. doi:10.1029/94JB03098

Caulet, J.-P., and Nigrini, C., 1988. The genus Pterocorys (Radiolaria) from the tropical late Neogene of the Indian and Pacific Oceans. Micropaleontology, 34:217-235.
Ciesielski, P.F., and Bjørklund, K.R., 1995. Ecology, morphology, stratigraphy, and the paleoceanographic significance of Cycladophora davisiana davisiana. Part II: stratigraphy in the North Atlantic (DSDP Site 609) and Labrador Sea (ODP Site 646B). Mar. Micropaleontol., 25:67-86. doi:10.1016/0377-8398(94)00027-K

CLIMAP Project Members, 1976. The surface of the ice-age Earth. Science, 191:1131-1137.

Conte, M.H., Volkman, J.K., and Eglinton, G., 1994. Lipid biomarkers of Haptophyta. In Green, J.C., and Leadbeater, B.S.C. (Eds.), The Haptophyte Algae: Oxford (Clarendon Press), 351-377.

De Carlo, E.H., 1992. Geochemistry of pore water and sediments recovered from the Exmouth Plateau. In von Rad, U., Haq, B.U., et al., Proc. ODP, Sci. Results, 122: College Station, TX (Ocean Drilling Program), 295-308.

Dwyer, G.S., Cronin, T.M., Baker, P.A., Raymo, M.E., Buzas, J.S., and Correge, T., 1995. North Atlantic deepwater temperature change during Late Pliocene and late Quaternary climatic cycles. Science, 270:1347-1351.

Eglinton, G., and Hamilton, R.J., 1963. The distribution of alkanes. In Swain, T. (Ed.), Chemical Plant Taxonomy: London (Academic Press), 187-208.

Eglinton, G., and Hamilton, R.J., 1967. Leaf epicuticular waxes. Science, 156:1322-1335.

Eglinton, G., Hamilton, R.J., Raphael, R.A., and Gonzalez, A.G., 1962. Hydrocarbon constituents of the wax coatings of plant leaves: a taxonomic survey. Nature (London, U. K.), 193:739-742.

Haslett, S.K., 1994. Plio-Pleistocene radiolarian biostratigraphy and paleoceanography of the mid-latitude North Atlantic (DSDP Site 609). Geol. Mag., 131:57-66.

Haslett, S.K., 2004. Late Neogene-Quaternary radiolarian biostratigraphy: a brief review. J. Micropaleontol., 23:39-47.

Hayward, B.W., 2001. Global deep-sea extinctions during the Pleistocene ice-ages. Geology, 29:599-602. doi:10.1130/00917613(2001)029<0599:GDSEDT>2.0.CO;2

Hilgen, F.J., and Krijgsman, W., 1999. Cyclostratigraphy and astrochronology of the Tripoli diatomite formation (pre-evaporite Messinian, Sicily, Italy). Terra Nova, 11:16-22. doi:10.1046/j.1365-3121.1999.00221.x

Hodell, D.A., Curtis, J.H., Sierro, F.J., and Raymo, M.E., 2001. Correlation of late Miocene to Early Pliocene sequences between the Mediterranean and North Atlantic. Paleoceanogr., 16:164-178. doi:10.1029/ 1999PA000487

Imbrie, J., Berger, A., Boyle, E., Clemens, S., Duffy, A., Howard, W., Kukla, G., Kutzbach, J., Martinson, D., McIntyre, A., Mix, A., Molfino, B., Morley, J., Peterson, L., Pisias, N., Prell, W., Raymo, M., Shackleton, N., and Toggweiler, J., 1993. On the structure and origin of major glaciation cycles, 2 . The 100,000-year cycle. Paleoceanography, 8:699-735.

Kennett, J.P., and Srinivasan, M.S., 1983. Neogene Planktonic Foraminifera: A Phylogenetic Atlas: Stroudsburg, PA (Hutchinson Ross).

Kleiven, H.F., Jansen, E., Curry, W.B., Hodell, D.A., and Venz, K., 2003, Atlantic Ocean thermohaline circulation 
changes on orbital to suborbital timescales during the mid-Pleistocene. Paleoceanography, 18. doi:10.1029/ 2001PA000629

Koç, N., Hodell, D.A., Kleiven, H., and Labeyrie, L., 1999. High-resolution Pleistocene diatom biostratigraphy of Site 983 and correlations with isotope stratigraphy. In Raymo, M.E., Jansen, E., Blum, P., and Herbert, T.D. (Eds.), 1999. Proc. ODP, Sci. Results, 162: College Station, TX (Ocean Drilling Program), 51-62. [HTML]

Kunst, L., and Samuels, A.L., 2003. Biosynthesis and secretion of plant cuticular waxes. Prog. Lipid Res., 42:51-80.

Lisiecki, L.E., and Raymo, M.E., 2005. A Pliocene-Pleistocene stack of 57 globally distributed benthic $\delta^{18} \mathrm{O}$ records. Paleoceanography, 20. doi:10.1029/ 2004PA001071

Lourens, L.J., Antonarakou, A., Hilgen, F.J., Van Hoof, A.A.M., Vergnaud-Grazzini, C., and Zachariasse, W.J., 1996. Evaluation of the Plio-Pleistocene astronomical timescale. Paleoceanography, 11:391-413. doi:10.1029/ 96PA01125

Manabe, S., and Stouffer, R.J., 1999. Are two modes of thermohaline circulation stable? Tellus A, 51(3):400-411. doi:10.1034/j.1600-0870.1999.t01-3-00005.x

Martini, E., 1971. Standard Tertiary and Quaternary calcareous nannoplankton zonation. In Farinacci, A. (Ed.), Proc. 2nd Int. Conf. Planktonic Microfossils Roma: Rome (Ed. Tecnosci.), 2:739-785.

Motoyama, I., 1997. Origin and evolution of Cycladophora davisiana Ehrenberg (Radiolaria) in DSDP Site 192, Northwest Pacific. Mar. Micropaleontol., 30:45-63. doi:10.1016/S0377-8398(96)00047-3

Müller, P.J., 1977. C/N ratios in Pacific deep sea sediments: effect of inorganic ammonium and organic nitrogen compounds sorbed by clays. Geochim. Cosmochim. Acta, 41:765-776. doi:10.1016/0016-7037(77)90047-3

Müller, P.J., Kirst, G., Ruhland, G., von Storch, I., and Rosell-Melé, A., 1998. Calibration of the alkenone paleotemperature index $\left(\mathrm{Uk}^{\mathrm{k}^{\prime}}{ }_{37}\right)$ based on core-tops from the eastern South Atlantic and the global ocean $\left(60^{\circ} \mathrm{N}-\right.$ $60^{\circ}$ S). Geochim. Cosmochim. Acta. 62:1757-1772. doi:10.1016/S0016-7037(98)00097-0

Murray, J.W., 1991. Ecology and Palaeoecology of Benthic Foraminifera: London (Longman).

Okada, H., 2000. Neogene and Quarternary calcareous nannofossils from the Blake Ridge, Sites 994, 995, and 997. In Paull, C.K., Matsumoto, R., Wallace, P.J., and Dillon, W.P. (Eds.), Proc. ODP, Sci. Results, 164: College Station, TX (Ocean Drilling Program), 331-341. [HTML]

Pflaumann, U., Sarnthein, M., Chapman, M., de Abreu, L., Funnell, B., Huels, M., Kiefer, T., Maslin, M., Schulz, H., Swallow, J., van Kreveld, S., Vautravers, M., Vogelsang, E. and Weinelt, M., 2003. Glacial North Atlantic: seasurface conditions reconstructed by GLAMAP 2000. Paleoceanography, 18(3). doi:10.1029/2002PA000774

Prahl, F.G., and Wakeham, S.G., 1987. Calibration of unsaturation patterns in long-chain ketone compositions for paleotemperature assessment. Nature (London, U. K.), 330:367-369. doi:10.1038/330367a0

Prahl, F.G., Muehlhausen, L.A., and Zahnle, D.L., 1988. Further evaluation of long-chain alkenones as indicators of paleoceanographic conditions. Geochim. Cosmo- chim. Acta, 52:2303-2310. doi:10.1016/00167037(88)90132-9

Raymo, M.E., 1992. Global climate change: a three million year perspective. In Kukla, G.J., and Went, E. (Eds.), Start of a Glacial. NATO ASI Ser. I: Berlin (Springer-Verlag), 3:207-223.

Raymo, M.E., Oppo, D.W., Flower, B.P., Hodell, D.A., McManus, J.F., Venz, K.A., Kleiven, K.F., and McIntyre, K., 2004. Stability of North Atlantic water masses in face of pronounced climate variability during the Pleistocene. Paleoceanography, 19. doi:10.1029/ 2003PA000921

Raymo, M.E., Ruddiman, W.F., Backman, J., Clement, B.M., and Martinson, D.G., 1989. Late Pliocene variation in Northern Hemisphere ice sheets and North Atlantic deep water circulation. Paleoceanography, 4:413-446.

Rieley, G., Collier, R.J., Jones, D.M., Eglinton, G., Eakin, P.A., and Fallick, A.E., 1991. Sources of sedimentary lipids deduced from stable carbon-isotope analyses of individual compounds. Nature (London, U. K.), 352:425427. doi:10.1038/352425a0

Ruddiman, W.F., Kidd, R.B., Thomas, E., et al., 1987. Init. Repts. DSDP, 94 (Pts. 1 and 2): Washington (U.S. Govt. Printing Office).

Ruddiman, W.F., Raymo, M., and McIntyre, A., 1986. Matuyama 41,000-year cycles: North Atlantic Ocean and Northern Hemisphere ice sheets. Earth Planet. Sci. Lett., 80:117-129. doi:10.1016/0012-821X(86)90024-5

Ruddiman, W.F., Raymo, M.E., Martinson, D.G., Clement, B.M., and Backman, J., 1989. Pleistocene evolution: Northern Hemisphere ice sheets and North Atlantic Ocean. Paleoceanography, 4:353-412.

Sato, T., Kameo, K., and Mita, I., 1999. Validity of the latest Cenozoic calcareous nannofossil datums and its application to the tephrochronology. Earth Sci., 53:265-274.

Schiller, A., Mikolajewicz, U., and Voss, R., 1997. The stability of the North Atlantic thermohaline circulation in a coupled ocean-atmosphere general circulation model. Climate Dynamics, 13:325-347. doi:10.1007/ s003820050169

Schrader, H.-J., and Fenner, J., 1976. Norwegian Sea Cenozoic diatom biostratigraphy and taxonomy. In Talwani, M., Udintsev, G., et al., Init. Repts. DSDP, 38: Washington (U.S. Govt. Printing Office), 921-1099.

Shackleton, N.J., Crowhurst, S., Hagelberg, T., Pisias, N.G., and Schneider, D.A., 1995. A new late Neogene time scale: application to Leg 138 sites. In Pisias, N.G., Mayer, L.A., Janecek, T.R., Palmer-Julson, A., and van Andel, T.H. (Eds.), Proc. ODP, Sci. Results, 138: College Station, TX (Ocean Drilling Program), 73-101.

Sierro, F.J., Flores, J.A., Civis, J., González-Delgado, J.A., and Frances, G., 1993. Late Miocene globorotaliid event-stratigraphy and biogeography in the NE-Atlantic and Mediterranean. Mar. Micropaleontol., 21:143-168. doi:10.1016/0377-8398(93)90013-N

Sierro, F.J., Hilgen, F.J., Krijgsman, W., and Flores, J.A., 2001. The Abad composite (SE Spain): a Messinian reference section for the Mediterranean and the APTS. Paleogeogr., Paleoclimatol., Paleoecol., 168:141-169. doi:10.1016/S0031-0182(00)00253-4 
Spencer-Cervato, C., and Thierstein, H.R., 1997. First appearance of Globorotalia truncatulinoides; cladogenesis and immigration. Mar. Micropaleontol., 30:267-291. doi:10.1016/S0377-8398(97)00004-2

Spiegler, D., and Jansen, E., 1989. Planktonic foraminifer biostratigraphy of Norwegian Sea sediments: ODP Leg 104. In Eldholm, O., Thiede, J., Taylor, E., et al., Proc. ODP, Sci. Results, 104: College Station, TX (Ocean Drilling Program), 681-696. [PDF]

Thomas, E., Booth, L., Maslin, M.A., and Shackleton, N.J., 1995. Northeastern Atlantic benthic foraminifera during the last 45,000 years: changes in productivity seen from the bottom up. Paleoceangraphy, 10:545-562. doi:10.1029/94PA03056

Villanueva, J., Grimalt, J.O., Cortijo, E., Vidal, L., and Labeyrie, L., 1997. A biomarker approach to the organic matter deposited in the North Atlantic during the last climatic cycle. Geochim. Cosmochim. Acta, 61:46334646. doi:10.1016/S0016-7037(97)83123-7

Volkman, J.K., 2000. Ecological and environmental factors affecting alkenone distributions in seawater and sediments. Geochem., Geophys., Geosys., 1(9). doi:10.1029/ 2000GC000061

Weaver, P.P.E., and Clement, B.M., 1987. Magnetobiostratigraphy of planktonic foraminiferal datums, DSDP Leg 94, North Atlantic. In Ruddiman, W.F., Kidd, R.B., Thomas, E., et al., Init. Repts. DSDP, 94: Washington (U.S. Govt. Printing Office), 815-829.

Young, J.R., 1998. Neogene. In Bown, P.R. (Ed.), Calcareous Nannofossil Biostratigraphy: London (Kluwer Academic Publishers), 225-265.

Publication: 9 September 2006 MS 306-112 
Figure F1. Sites U1312 and U1313 drilled during Expedition 306 at locations of Site 607 and 608 . Site 609 was redrilled during Expedition 303 (Site U1308).

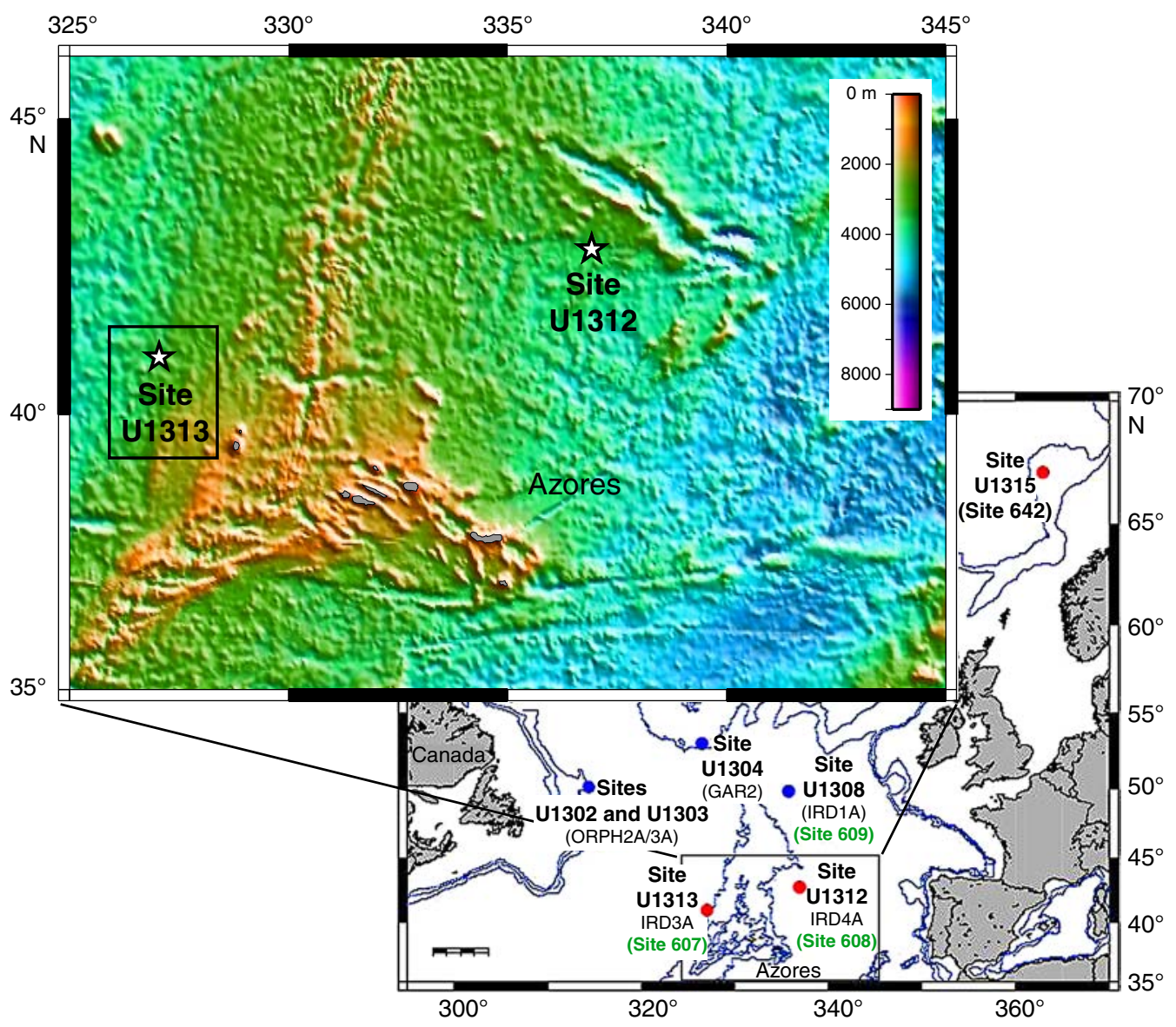


Figure F2. Air gun seismic profile collected around Site 607 during Leg 94 (Ruddiman, Kidd, Thomas, et al., 1987).

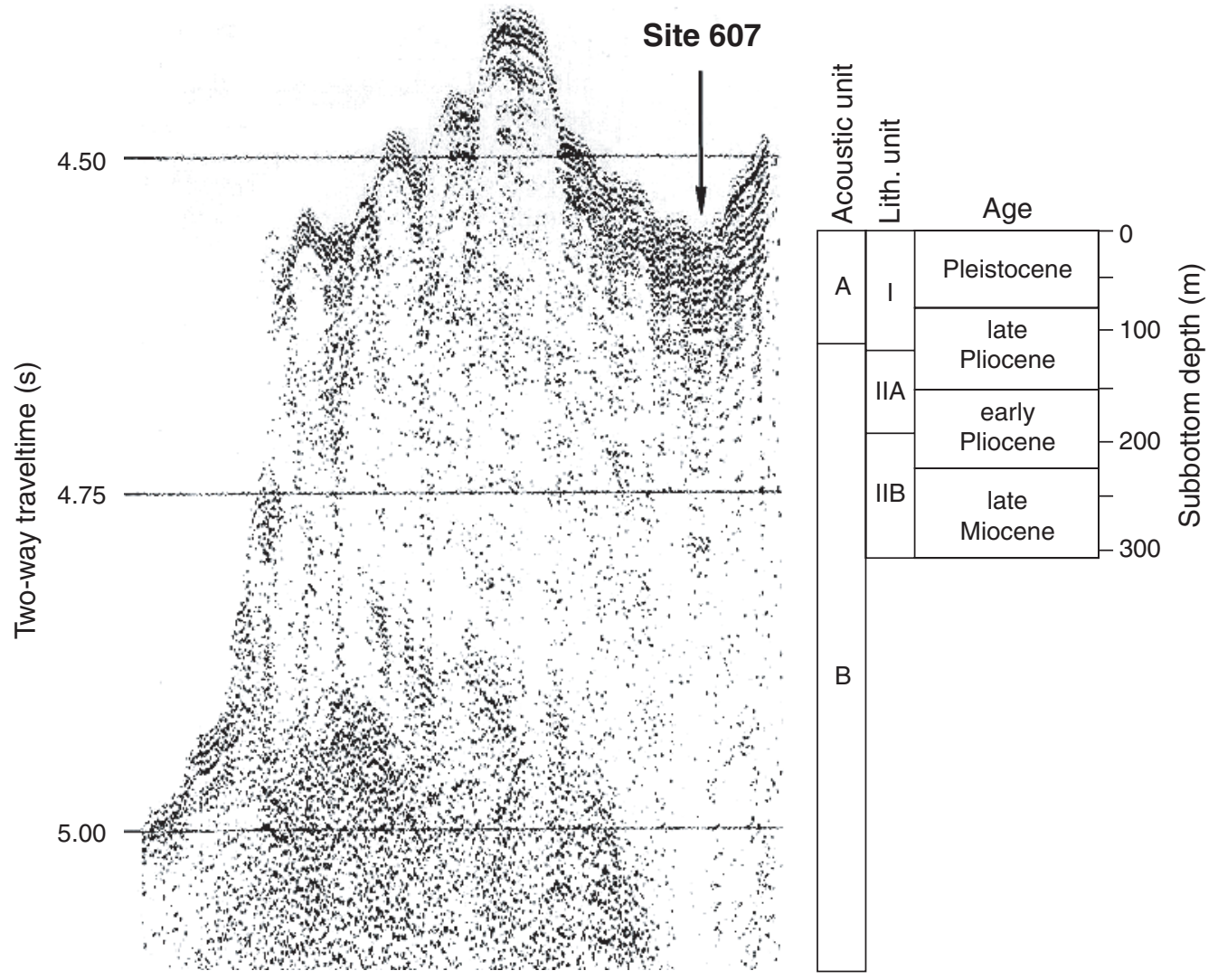


Figure F3. Lithologies, recovery (Ruddiman, Kidd, Thomas, et al., 1987), and benthic oxygen stable isotope record (Raymo et al., 1989, 2004) at Site 607. TD = total depth.

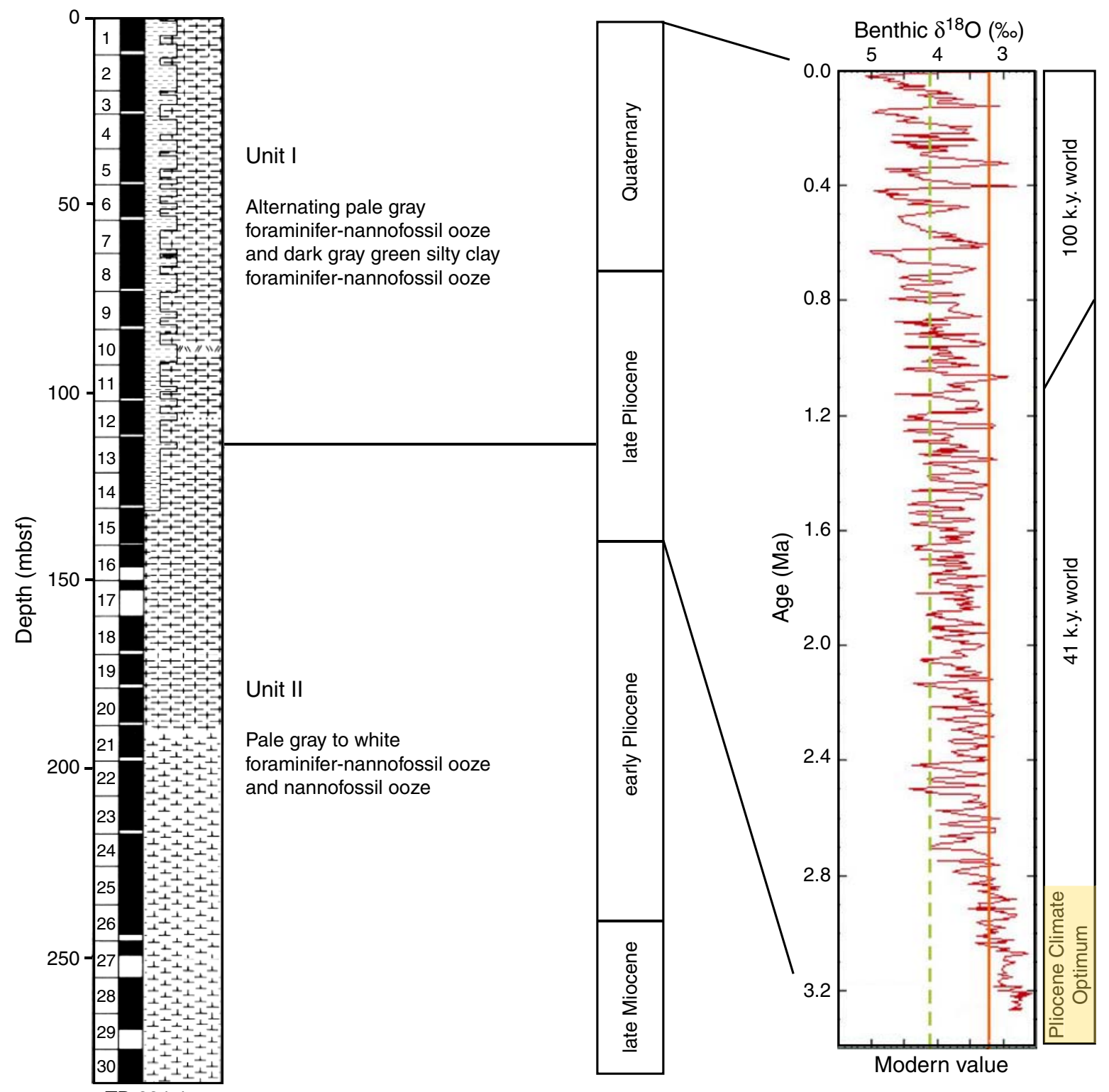


Figure F4. A. DSDP/ODP site locations. B. North-South Atlantic World Ocean Circulation Experiment A16 salinity profile with location of DSDP/ODP sites projected onto the profile (from Kleiven et al., 2003). NADW = North Atlantic Deep Water, CDW = Circumpolar Deep Water.
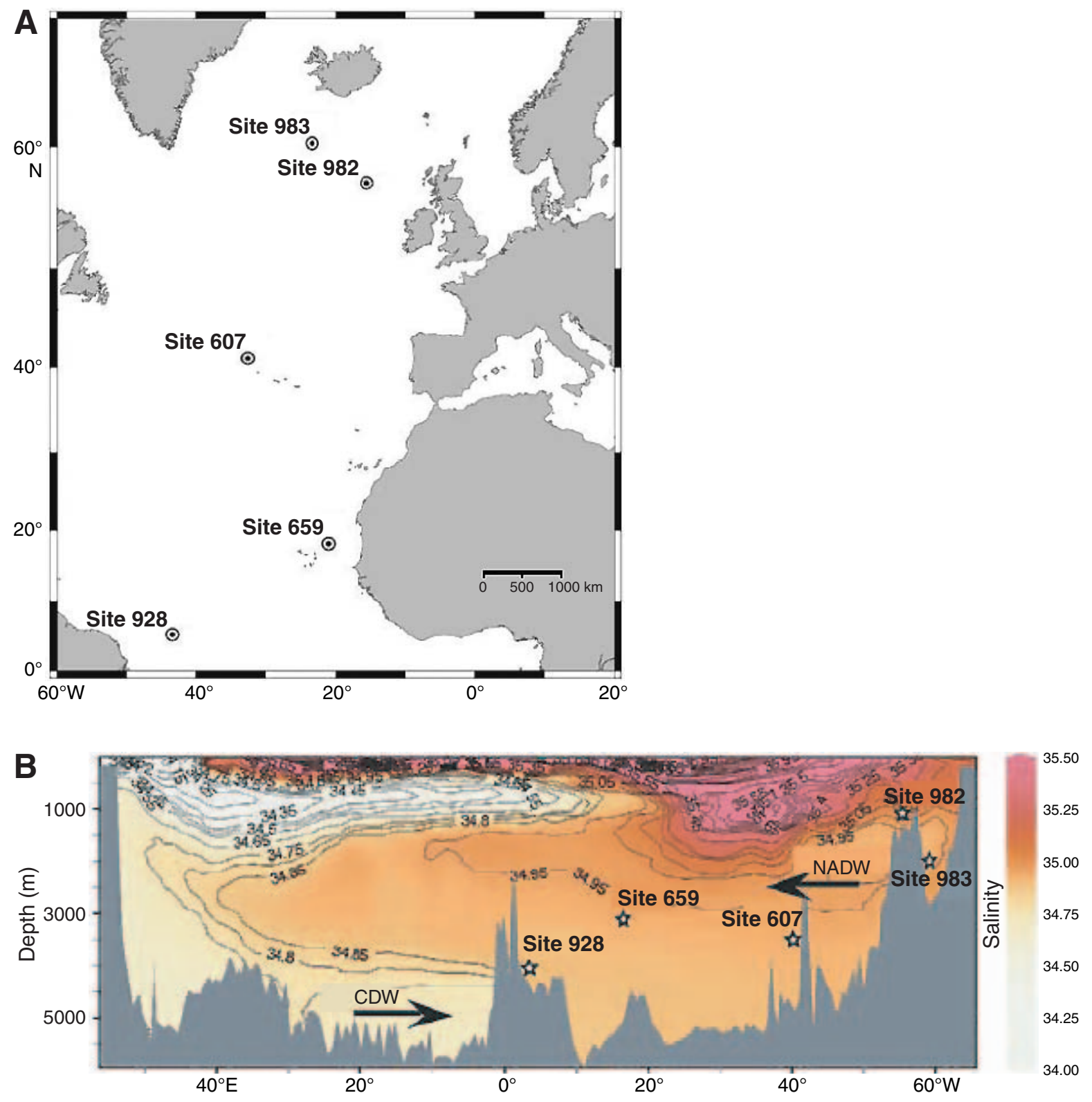
Figure F5. A. Glacial Atlantic Ocean Mapping (GLAMAP) 2000 sea-surface temperature (SST) reconstruction of the glacial Atlantic for northern summer (Pflaumann et al., 2003). Arrows indicate major current directions $($ solid $=$ cold, open $=$ warm). Locations of Site U1313 and Cores SU90/08 and MD952037 are shown. B. Alkenone $\mathrm{Uk}^{k_{37}}$-SST records of Cores SU90/08 and MD952037. Expanded boxes are of the last two glacial intervals (LGM and oxygen isotope Stage 6) (from Calvo et al., 2001).
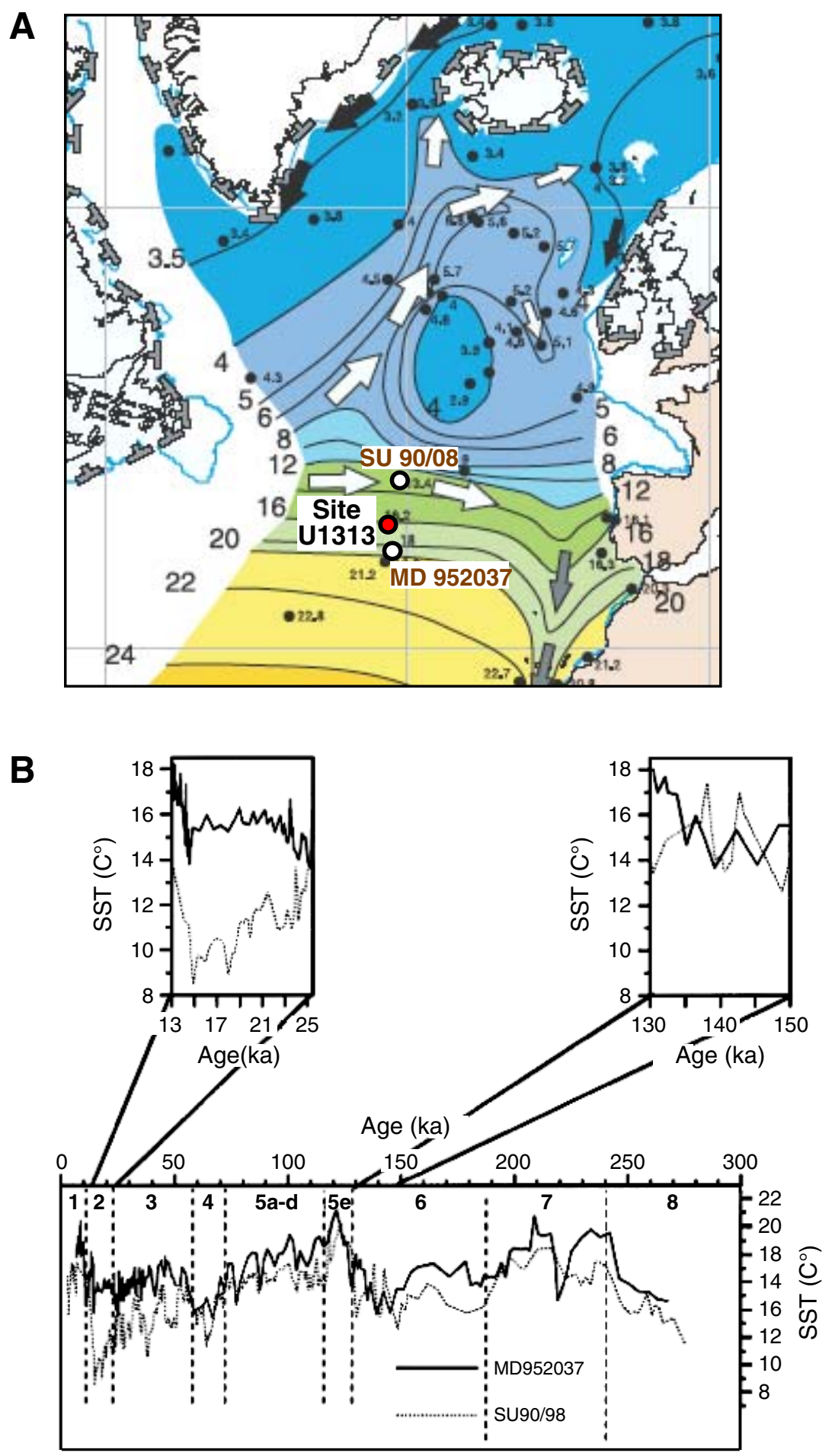
Figure F6. Relative abundances of terrigenous and biogenic sediment from dominant lithologies in Holes U1313A and U1313B. (Continued on next page.)

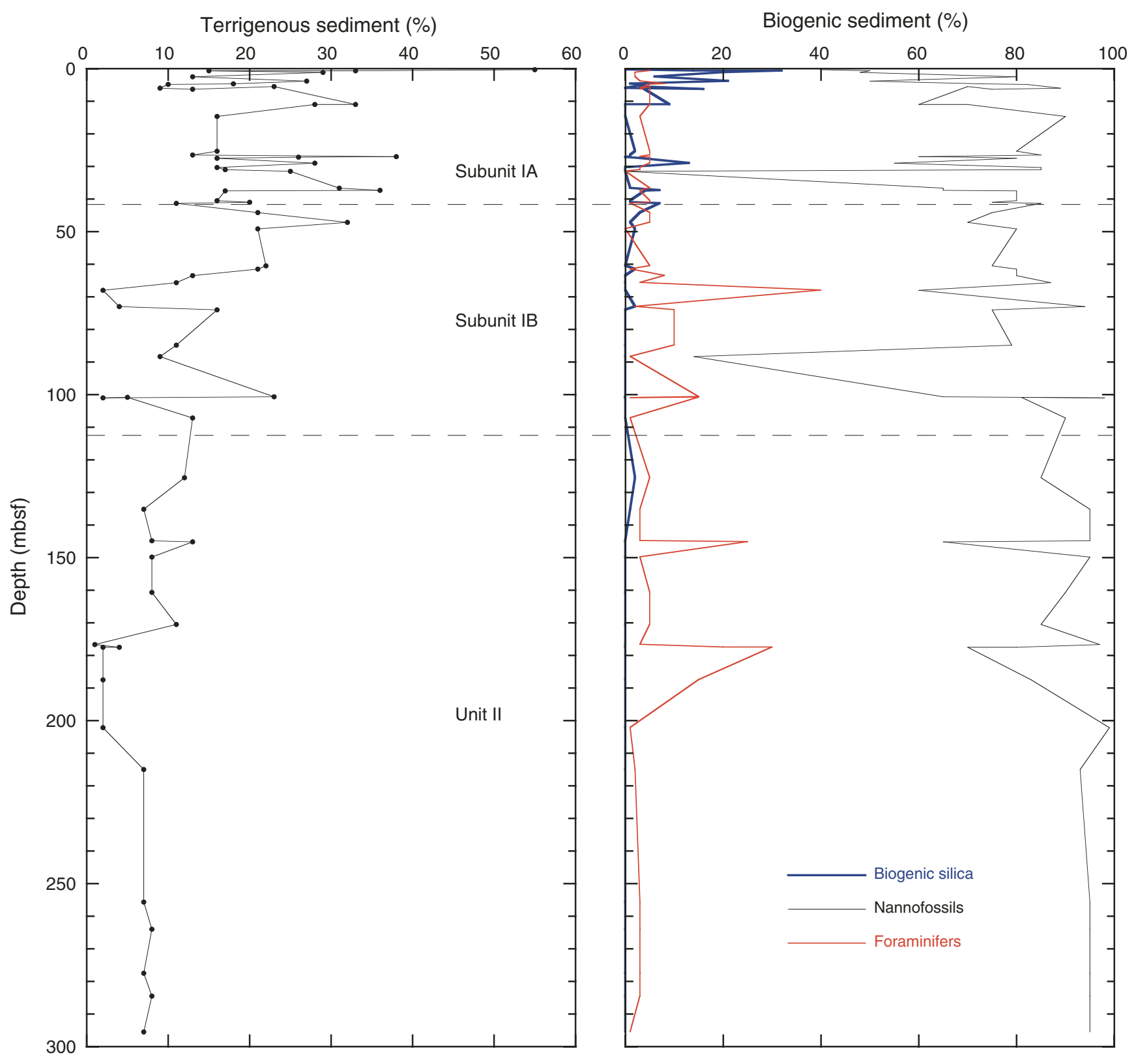


Figure F6 (continued).

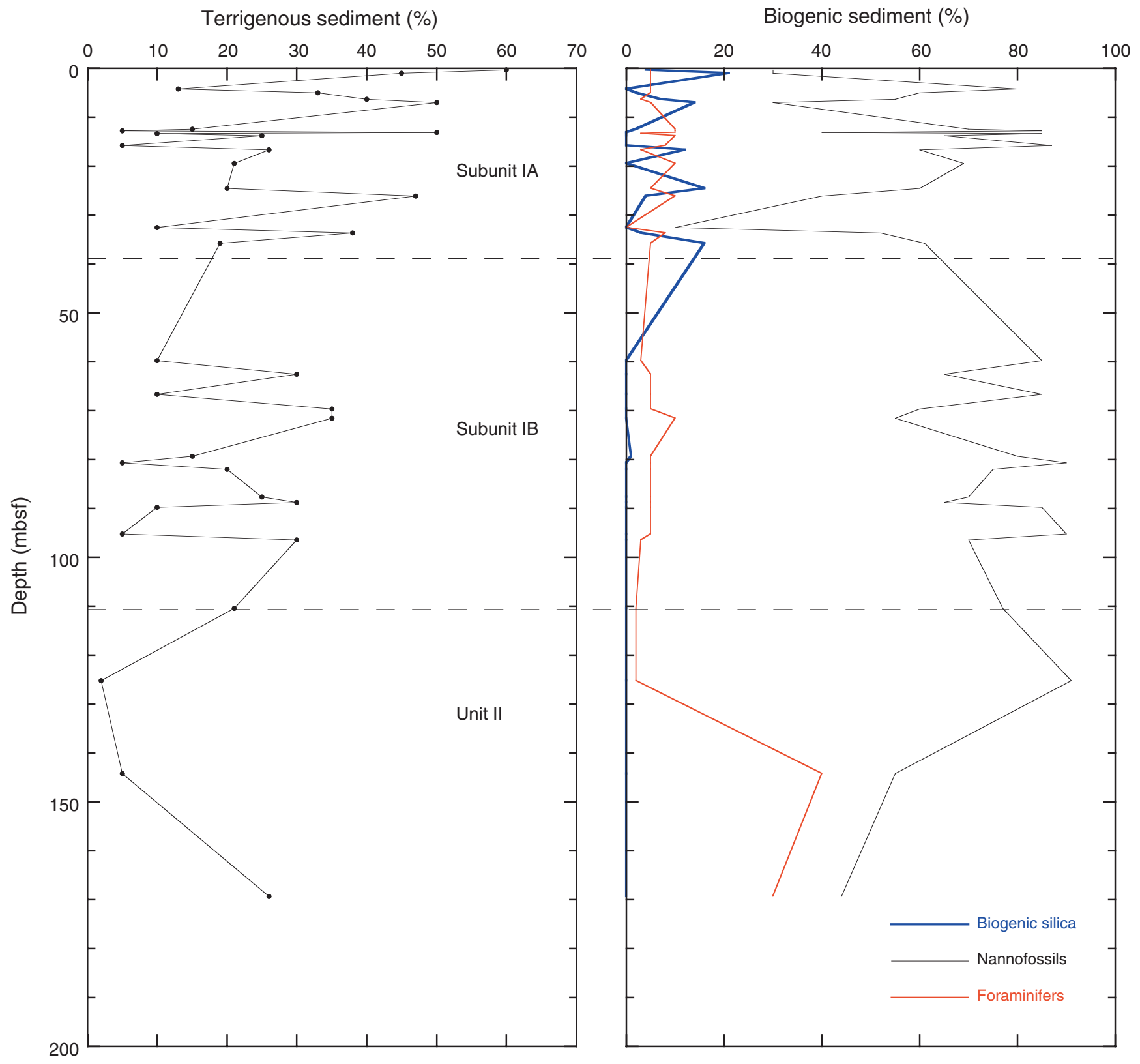


Figure F7. Schematic summary of core recovery at Site U1313 with recovered lithologic units and lithologies. Sediment lightness values were determined from color reflectance data (black) and carbonate values (blue).

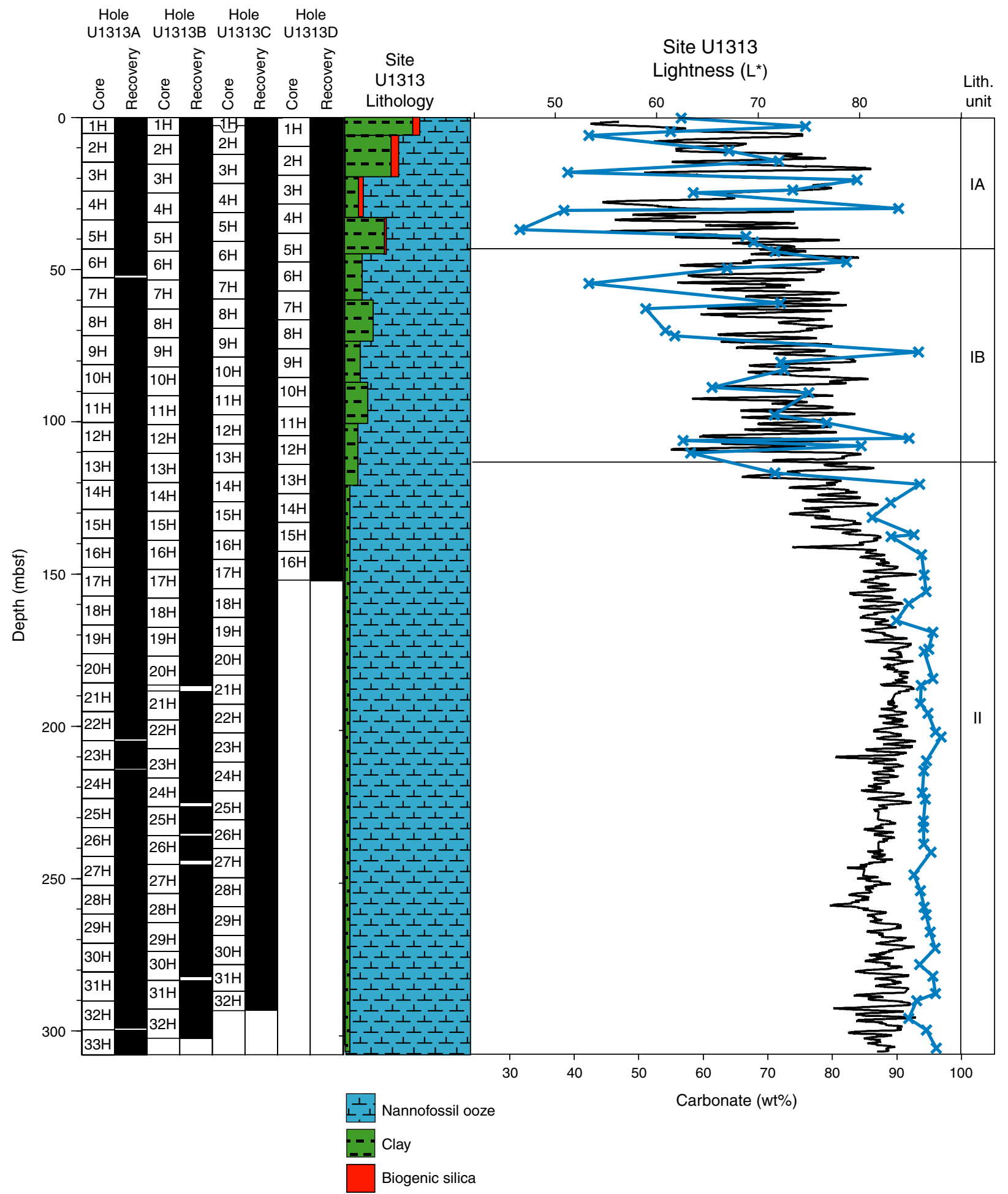


Figure F8. X-ray diffractogram of the carbonate-free fraction of Sample 306-U1313A-4H-2, 147-148 cm $(27.17$ mbsf).

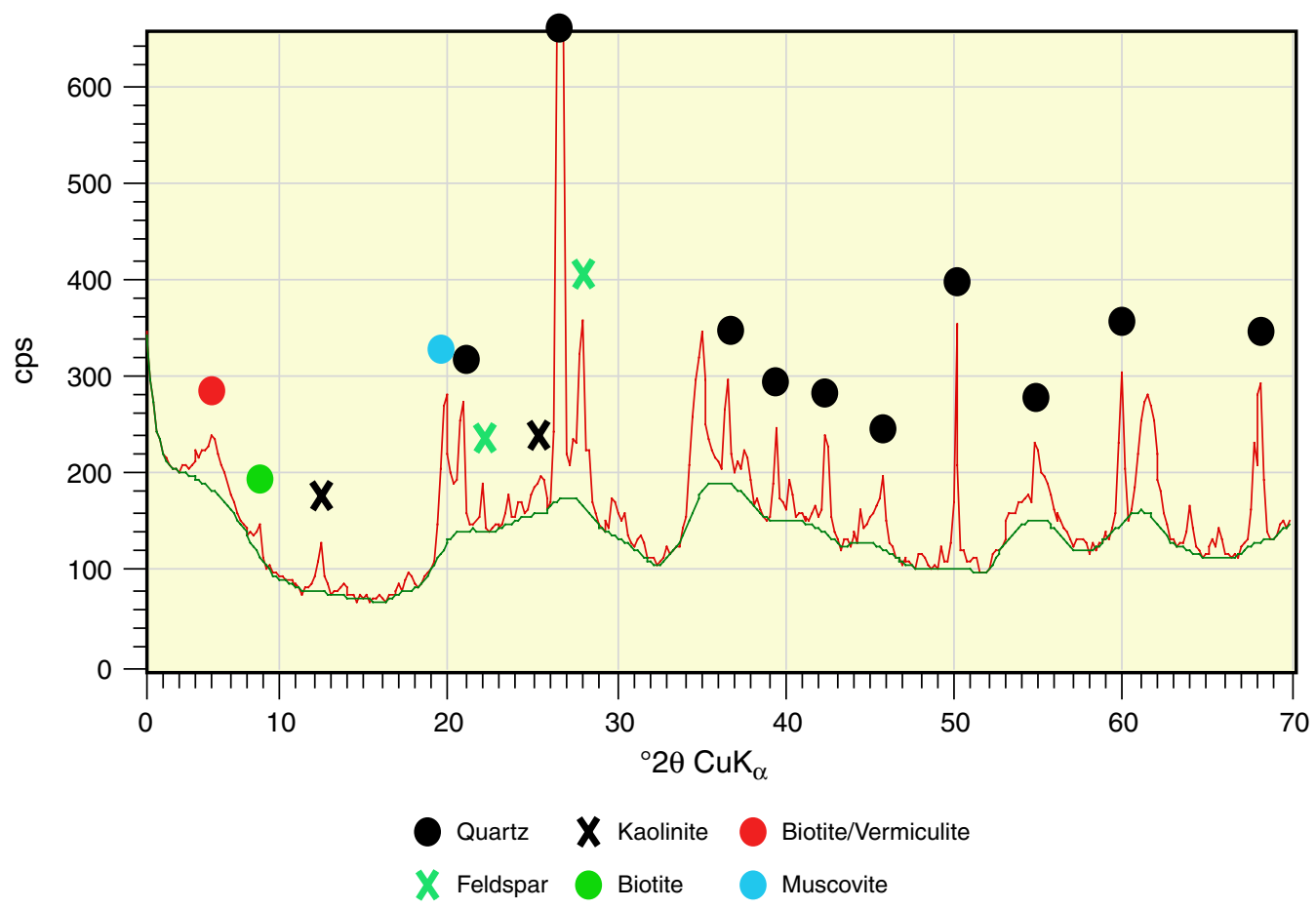


Figure F9. Schematic summary of ash bed (black), foraminifer-rich event bed (brown), and dropstone (solid circle) occurrence in Holes U1313A, U1313B, U1313C, and U1313D.

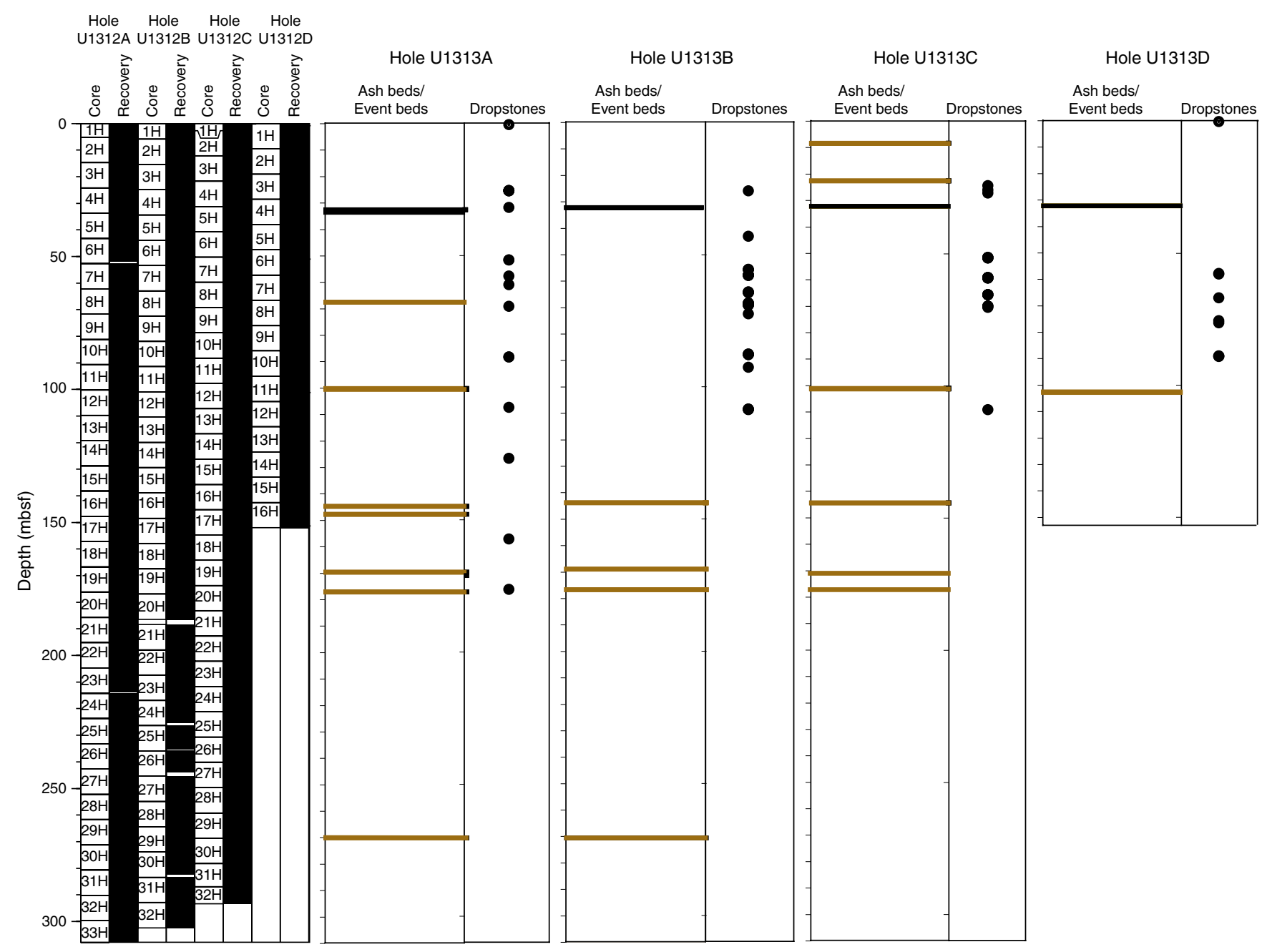


Figure F10. Foraminifer-nannofossil ooze with sharp, erosive lower contact and gradational upper contact; identified as a turbidite (Section 306-U1313C-12H-3; 74-107 cm, 101.66-101.77 mbsf).

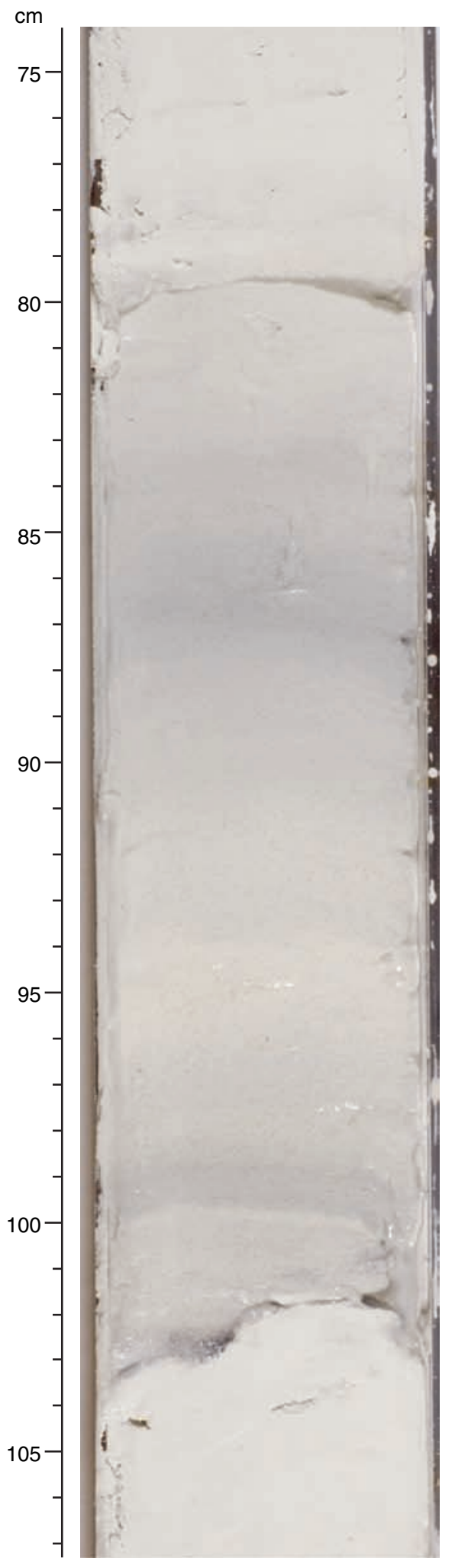


Figure F11. A. Reworked ash bed (Section 306-U1313A-4H-6; 118.5-141 cm; 32.885-33.11 mbsf). B. Volcanic glass from ash bed (plane-polarized light).

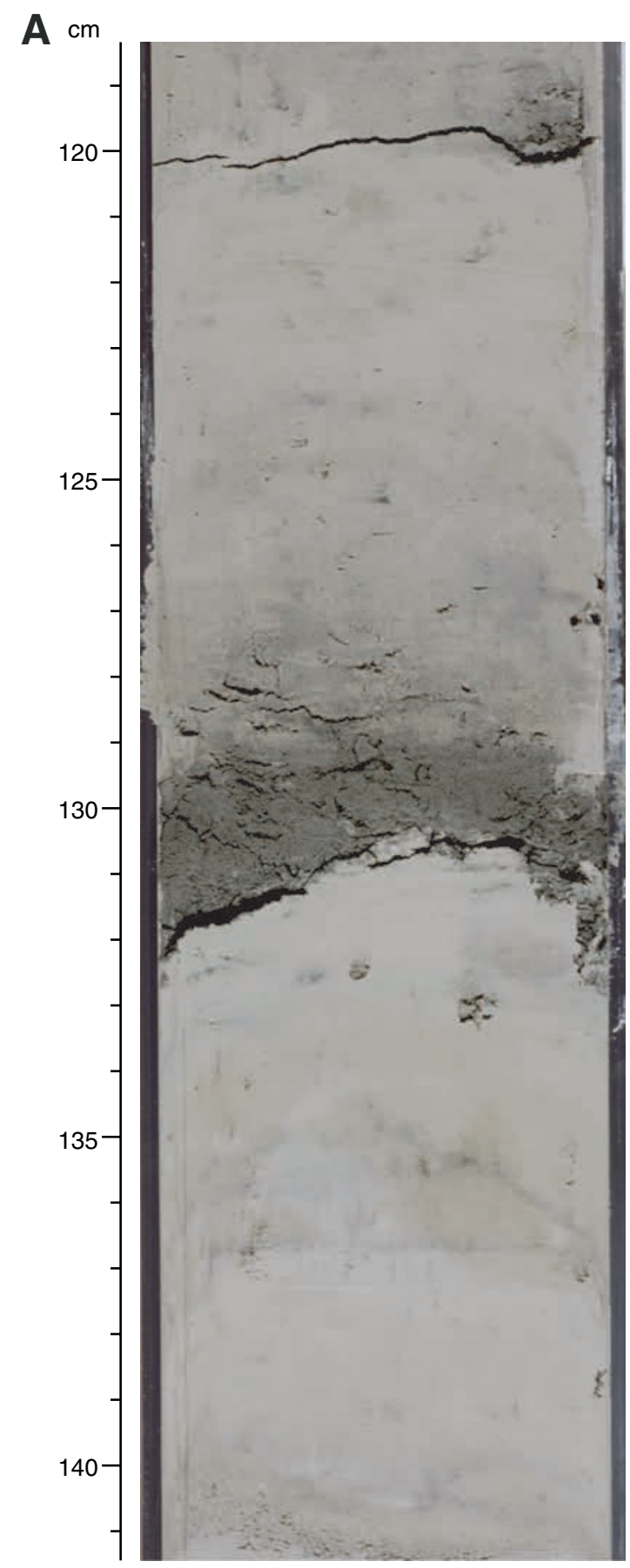

B

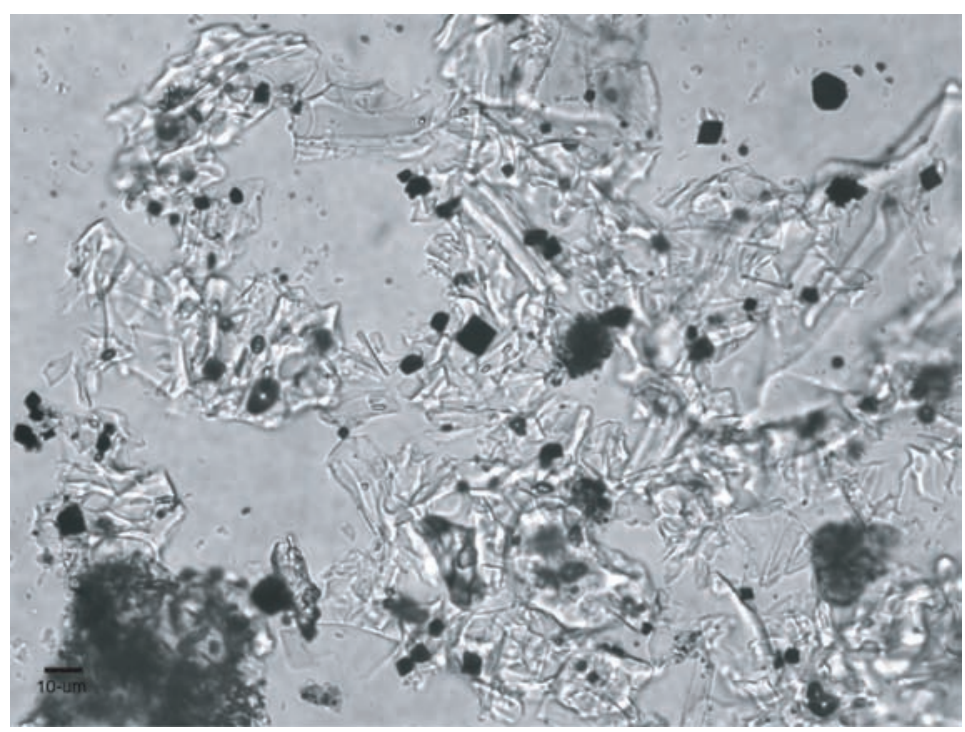


Figure F12. IRD carbonate layer (Section 306-U1313C-7H-6; 116.5-149 cm; 58.65-59.19 mbsf).

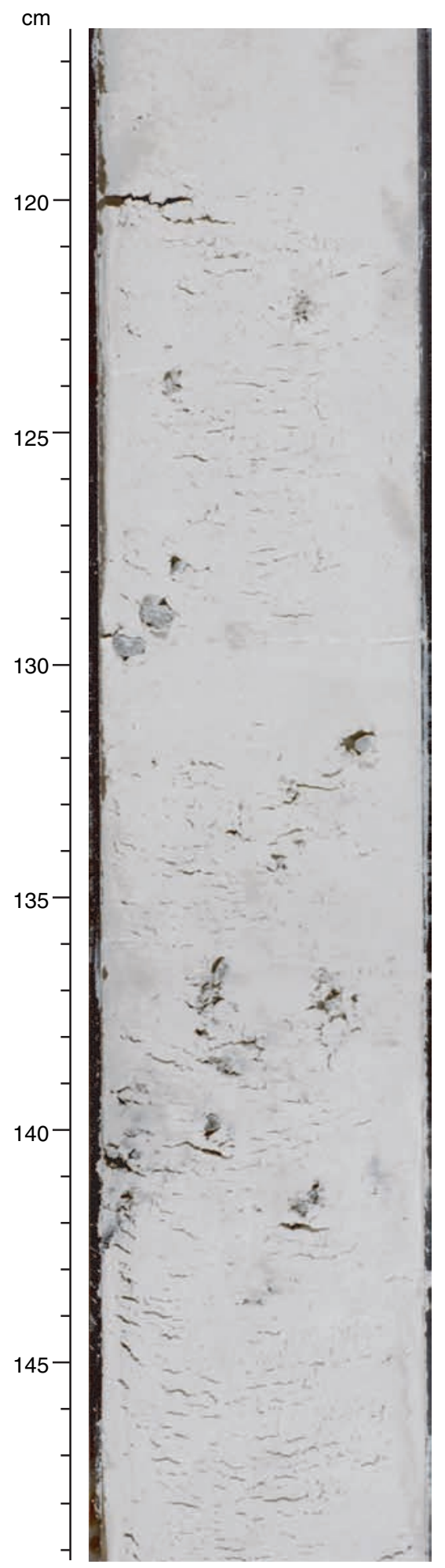


Figure F13. IRD igneous layer (Section 306-U1313A-10H-5; 110-132 cm; 88.30-88.52 mbsf).

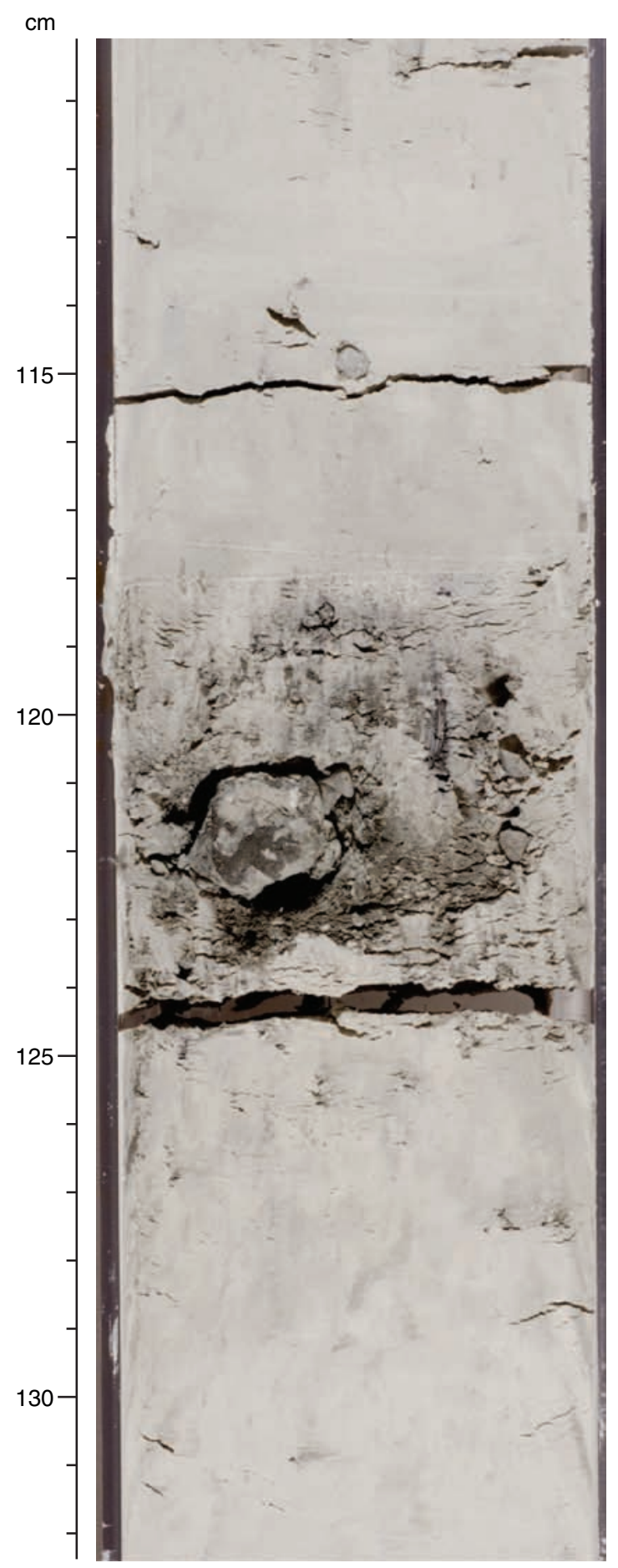


Figure F14. Time vs. depth plot and average sedimentation rates for different intervals of time in Hole U1313A. Biostratigraphic horizons used to construct the curve are given in Table T4. Paleomagnetism data for the curve are given in Table T24.

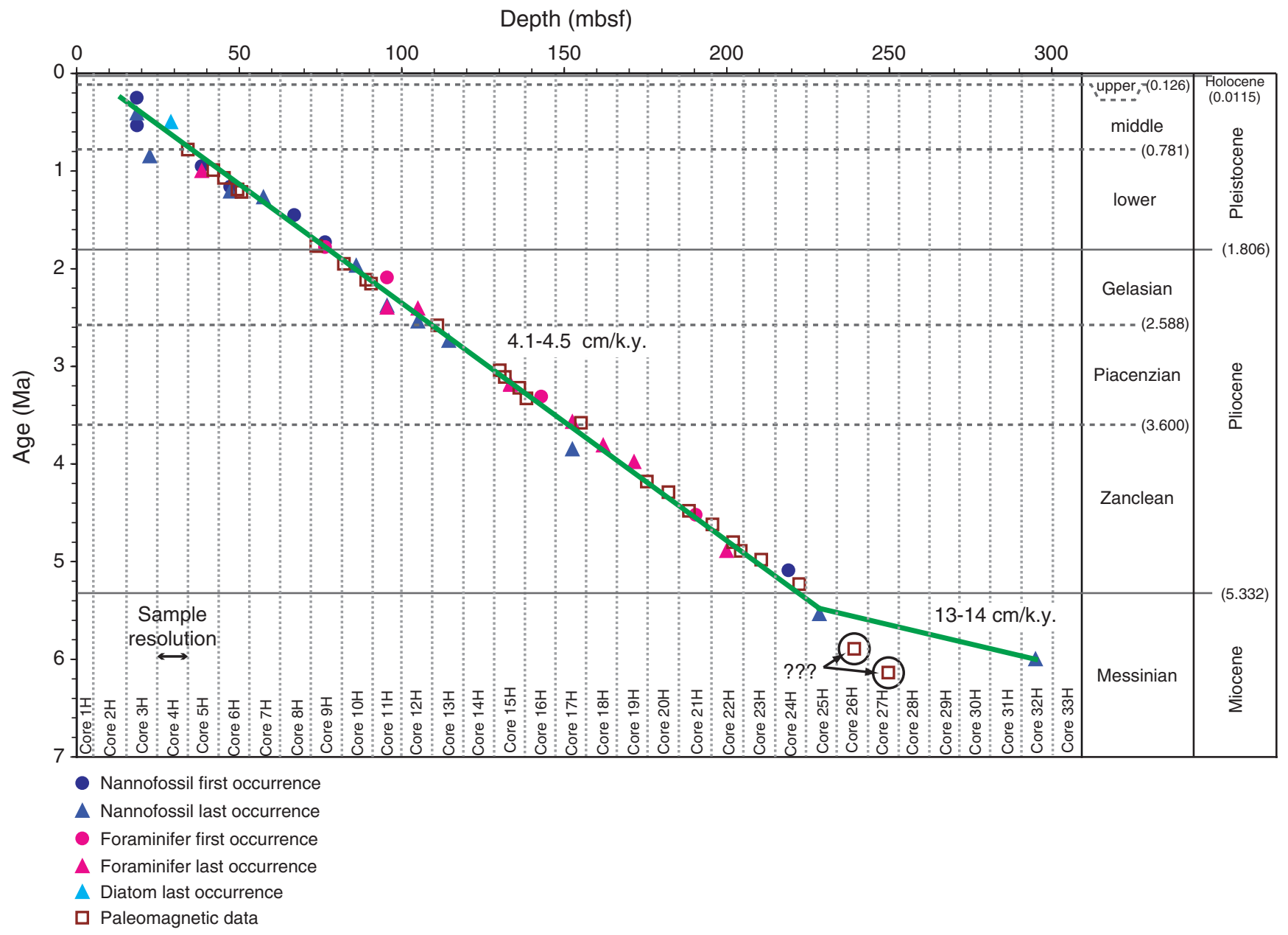


Figure F15. Time vs. depth plot and average sedimentation rates for different intervals of time in Hole U1313B. Biostratigraphic horizons used to construct the curve are given in Table T4. Paleomagnetism data for the curve are given in Table T24.

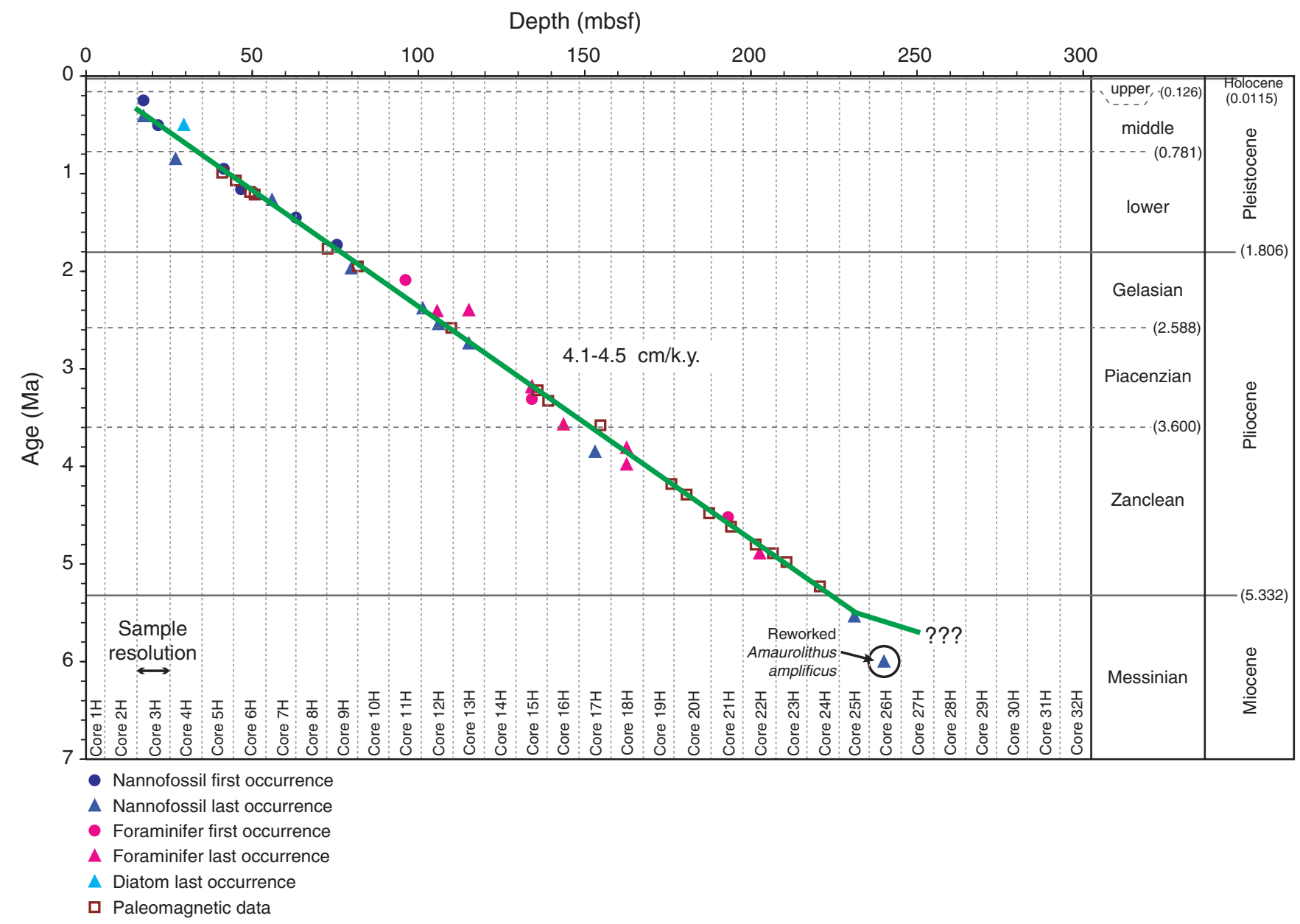


Figure F16. Time vs. depth plot and average sedimentation rates for different intervals of time in Hole U1313C. Biostratigraphic horizons used to construct the curve are given in Table T4. Paleomagnetism data for the curve are given in Table T24.

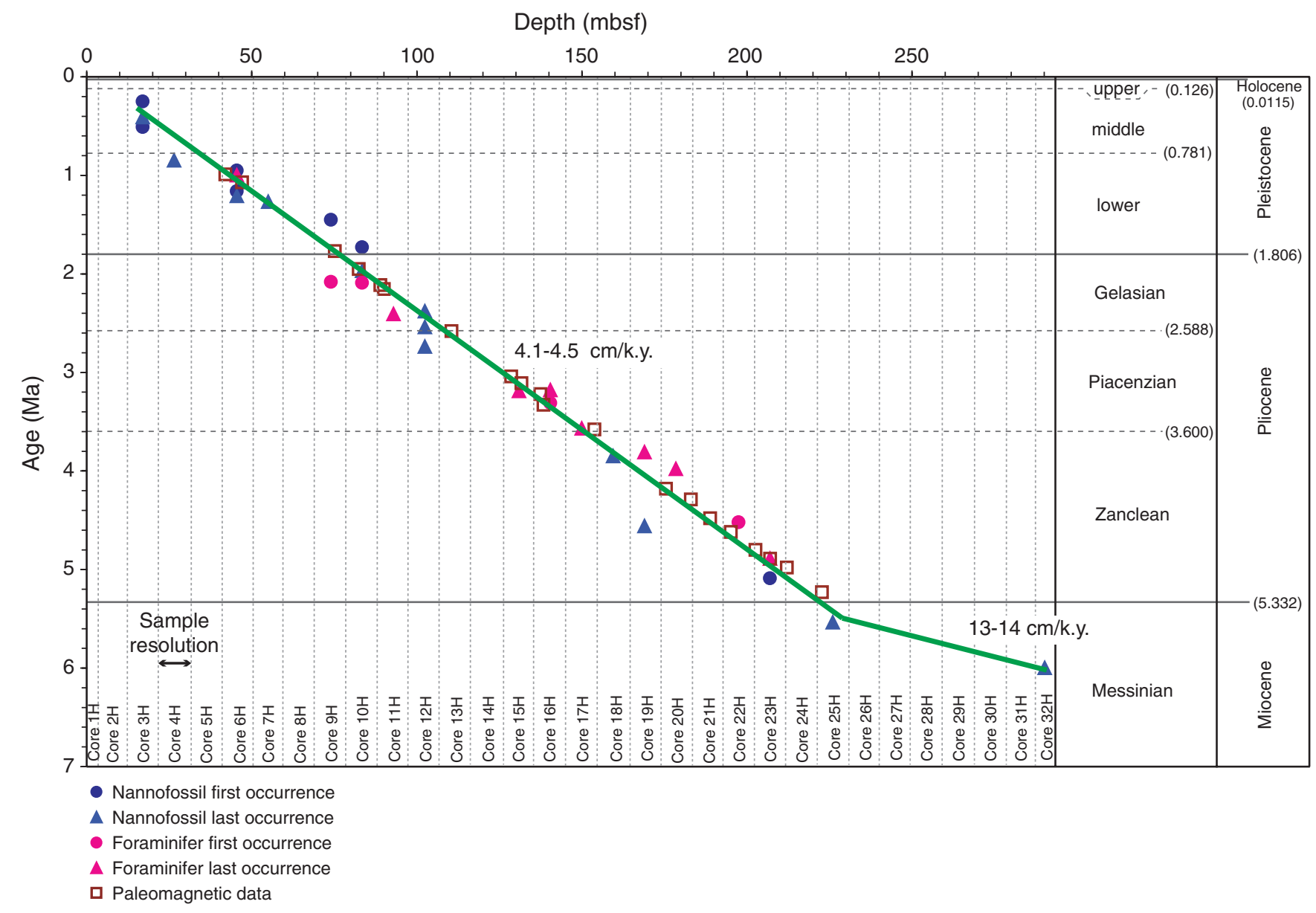


Figure F17. Time vs. depth plot and average sedimentation rates for different intervals of time in Hole U1313D. Biostratigraphic horizons used to construct the curve are given in Table T4. Paleomagnetism data for the curve are given in Table T24.

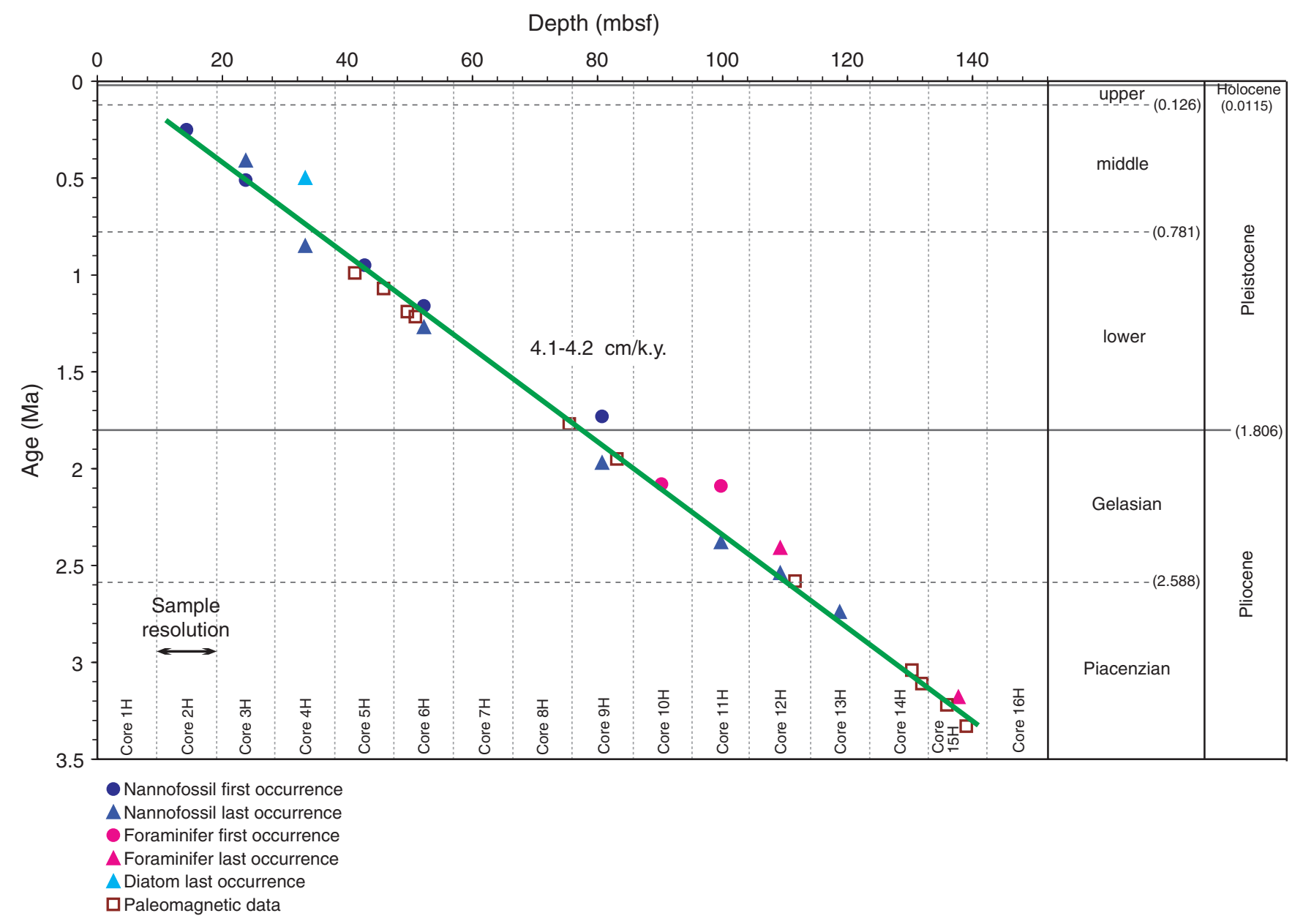


Figure F18. NRM intensity before (green) and after (red) AF demagnetization at $20 \mathrm{mT}$ vs. depth.

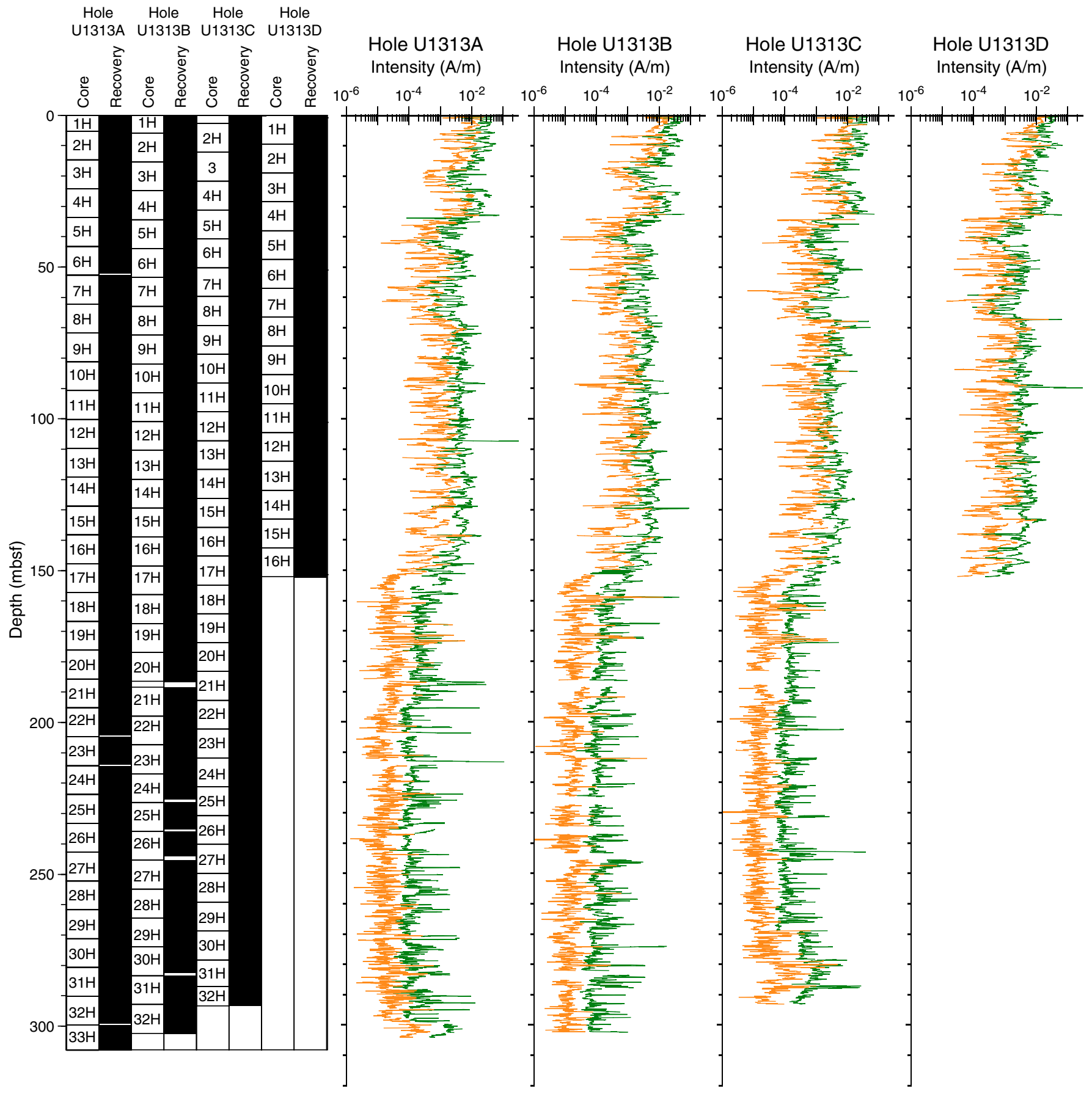


Figure F19. Inclination and declination of remanent magnetization after $20 \mathrm{mT}$ AF demagnetization vs. depth. Declination values have been corrected using Tensor tool data.

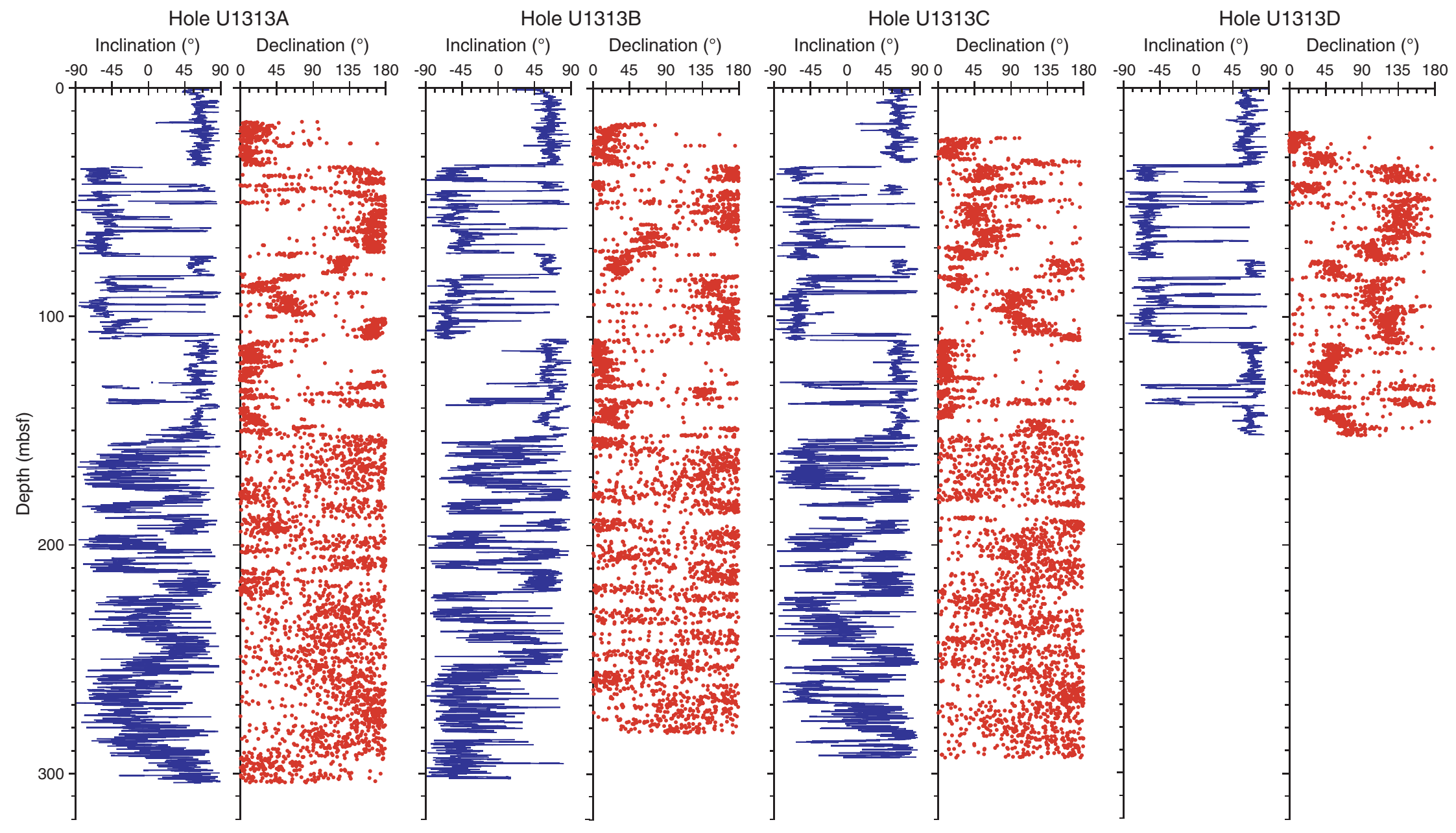


Figure F20. Inclination after $20 \mathrm{mT}$ AF demagnetization vs. depth. Paleomagnetic polarity interpretation (black $=$ normal polarity, white $=$ reversed polarity, gray $=$ undetermined polarity) is displayed on the right side of the figure along with the reference geomagnetic polarity timescale (Cande and Kent, 1995). The red lines indicate two possible ties to the geomagnetic polarity timescale for the deepest interval of normal polarity.

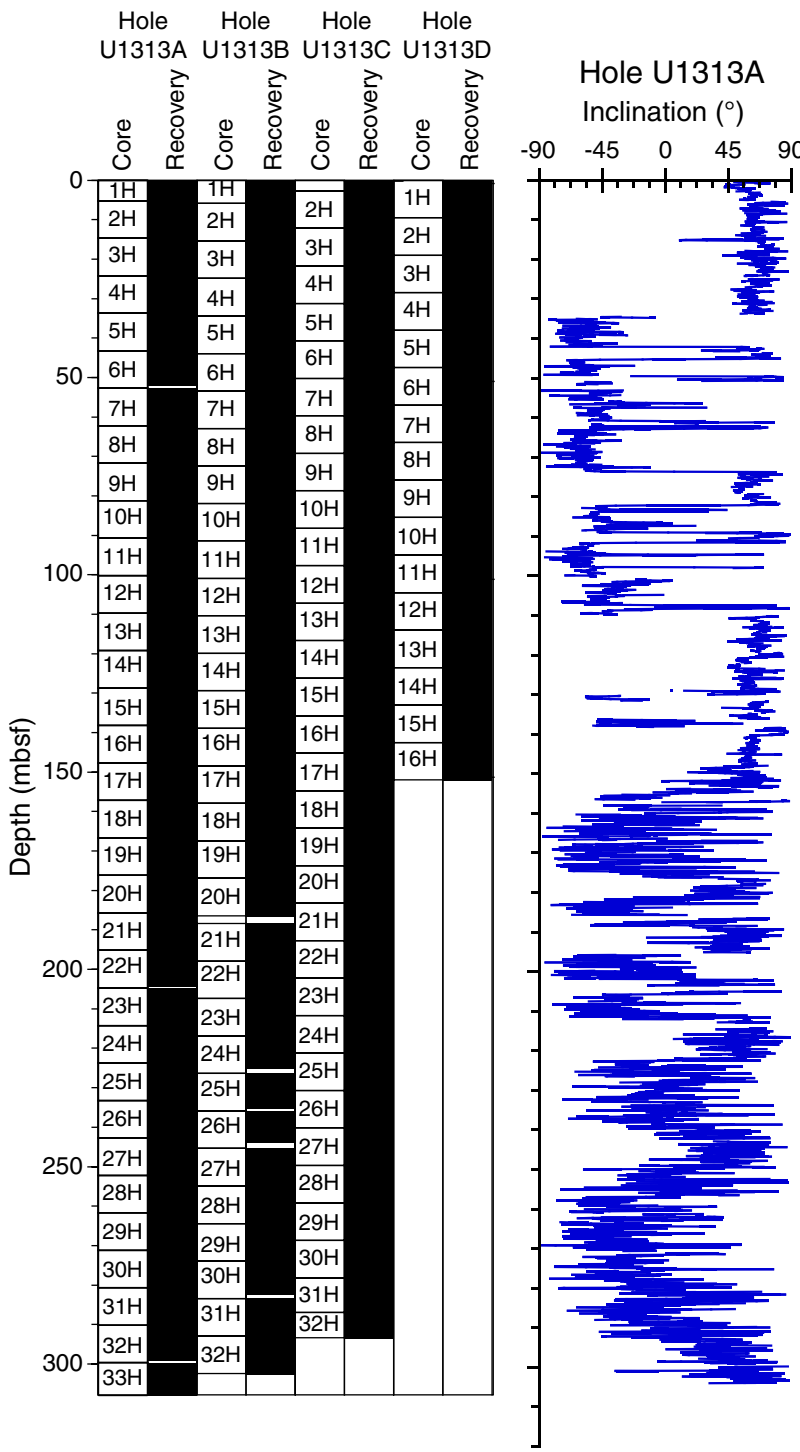

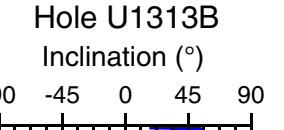

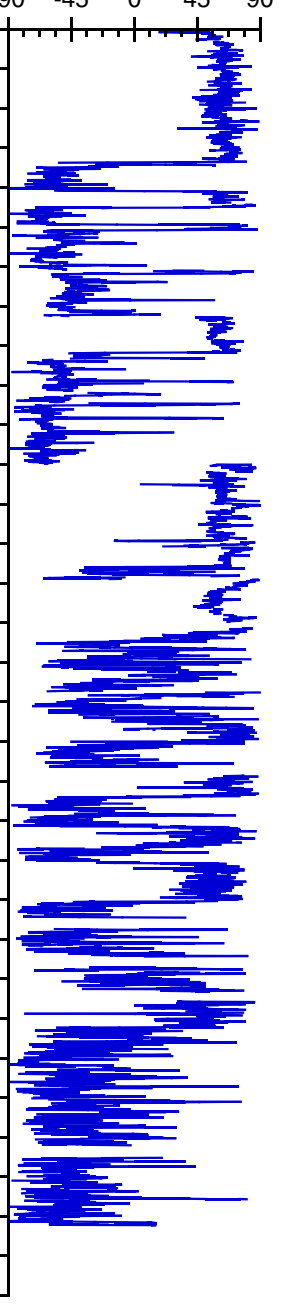

Hole U1313C

Inclination $\left(^{\circ}\right)$

$\begin{array}{llllllllll}-90 & -45 & 0 & 45 & 90 & -90 & -45 & 0 & 45 & 90\end{array}$

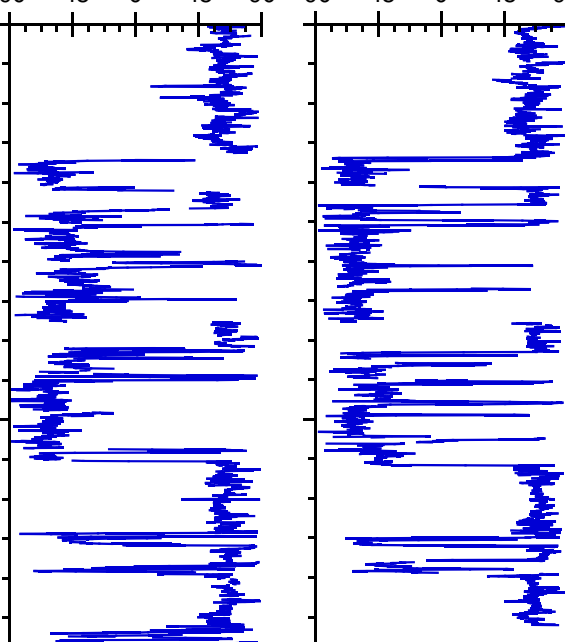


Figure F21. Color parameter L* vs. depth for Holes U1313A-U1313D. Upper panels show composite $\mathrm{L}^{*}$ record indicating which hole was used to form the primary sampling splice. Numbers in lower panels indicate cores. A. $0-80 \mathrm{mcd}$. (Continued on next page.)

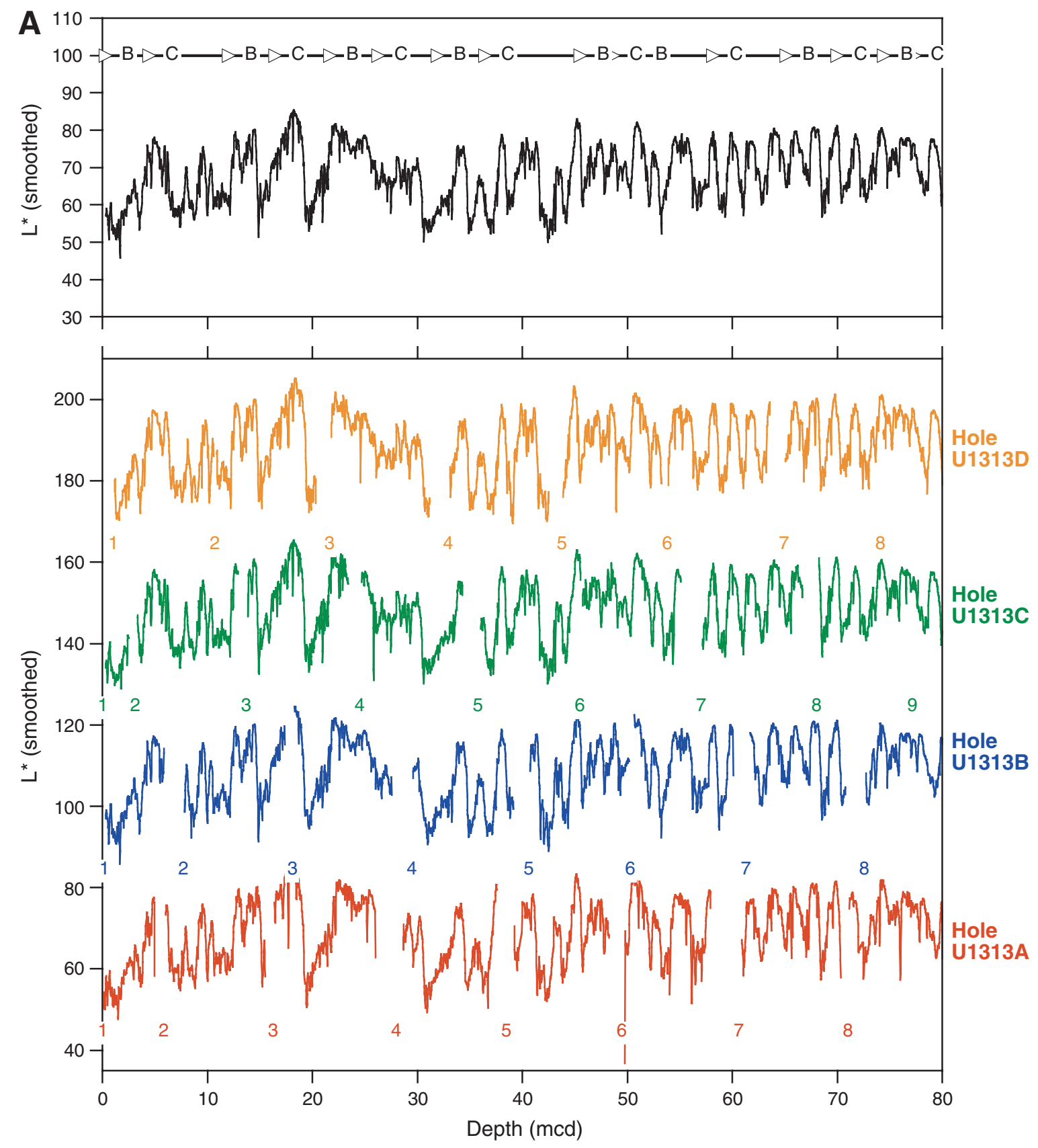


Figure F21 (continued). B. 80-160 mcd.

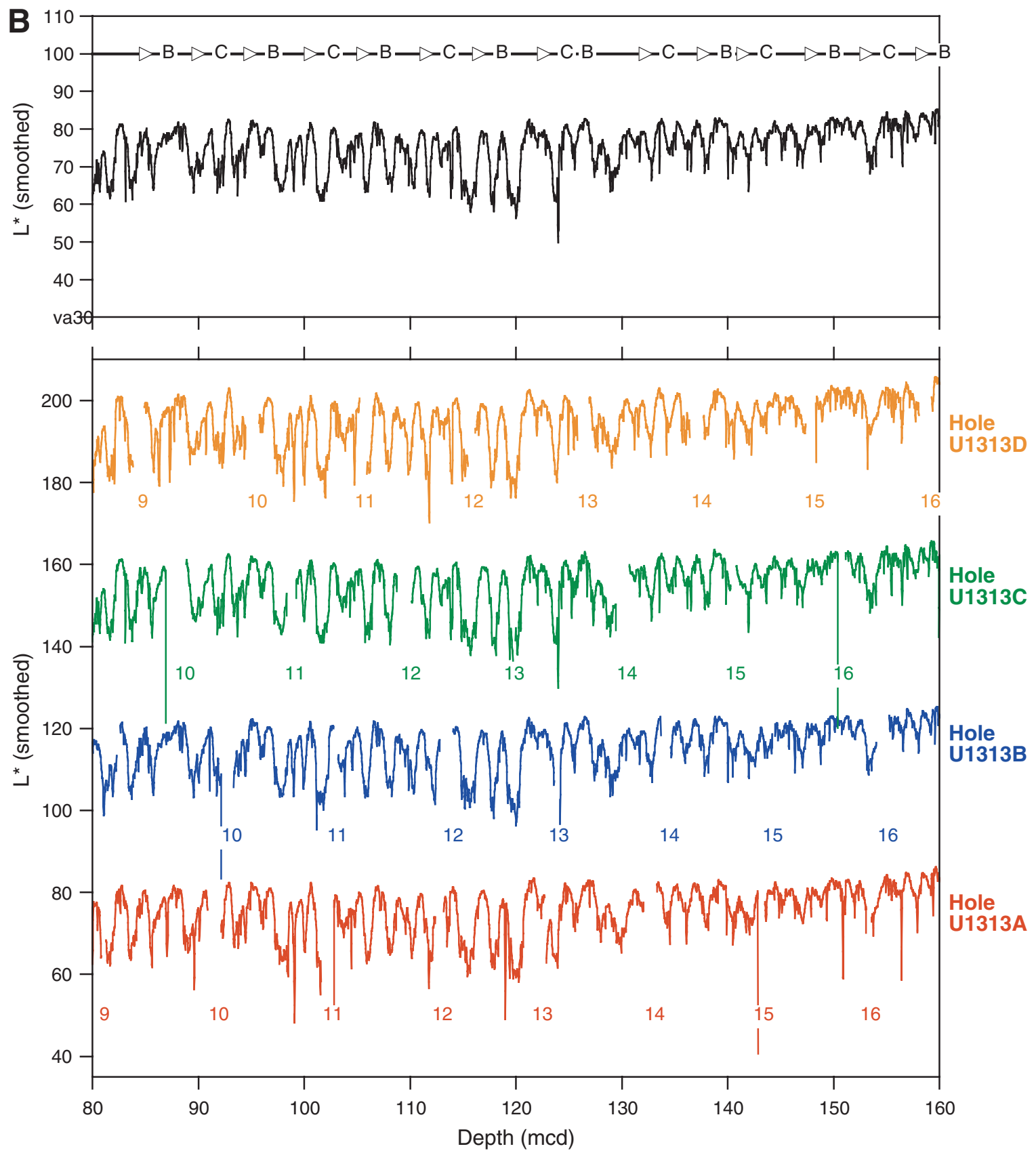


Figure F22. Magnetic susceptibility vs. depth for Holes U1313A-U1313D. Upper panels show composite magnetic susceptibility record indicating which hole was used to form the primary sampling splice. Numbers in lower panels indicate cores. A. 0-80 mcd. (Continued on next page.)
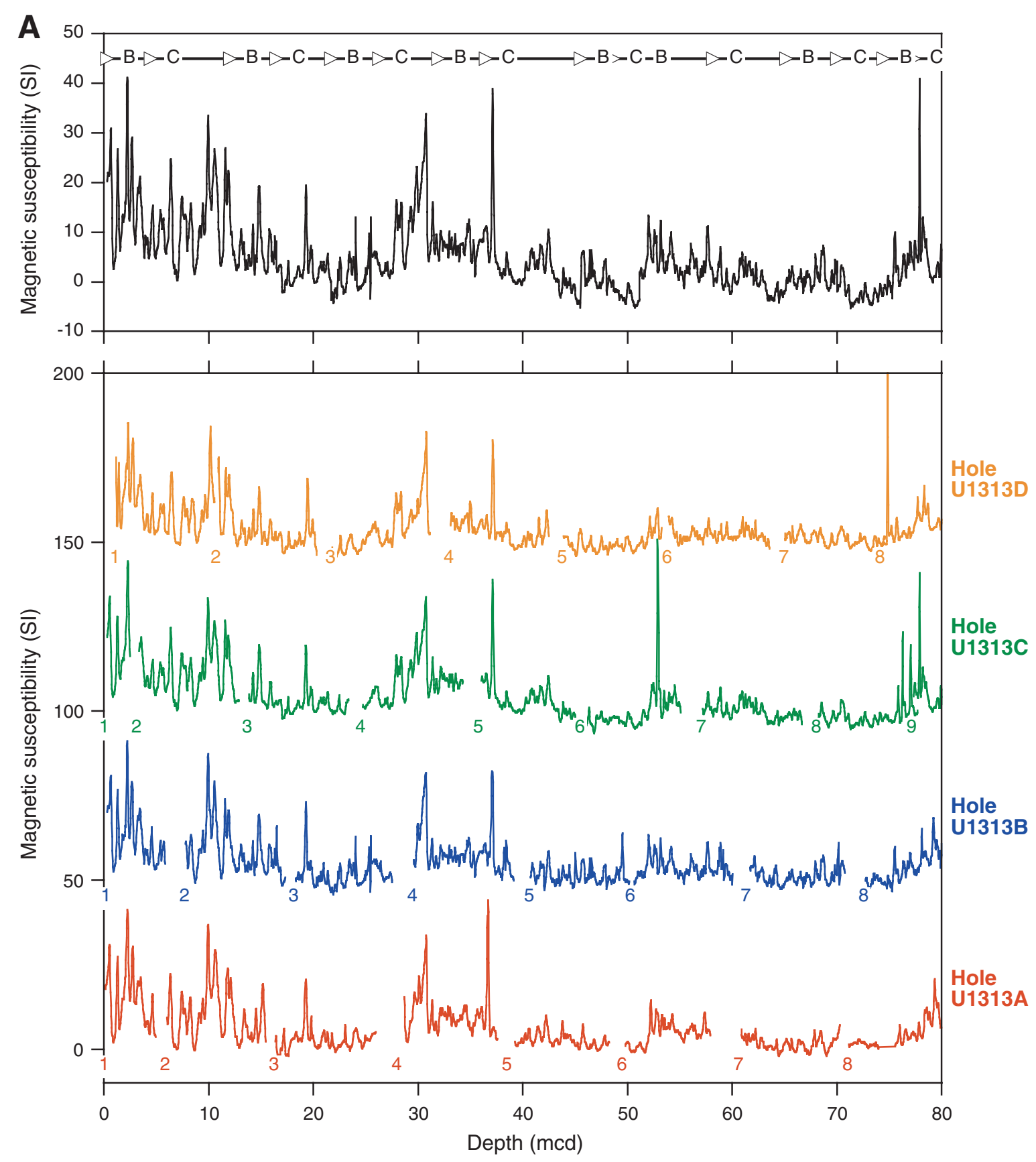
Figure F22 (continued). B. 80-160 mcd.

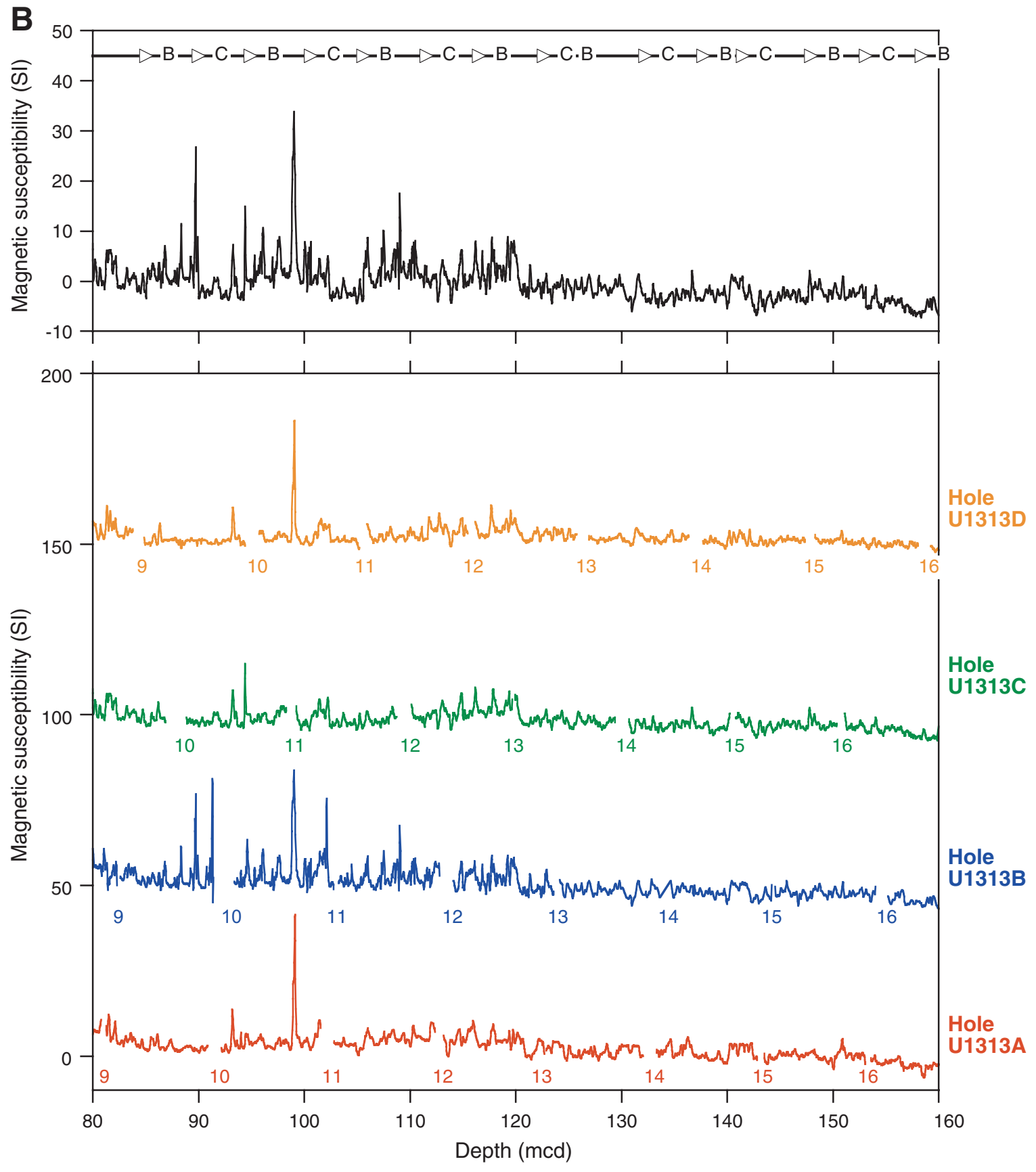


Figure F23. Paleomagnetic inclination after $20 \mathrm{mT}$ demagnetization vs. depth for Holes U1313A-U1313D. Upper panels show composite inclination record indicating which hole was used to form the primary sampling splice. Numbers in lower panels indicate cores. A. 0-80 mcd. (Continued on next three pages.)

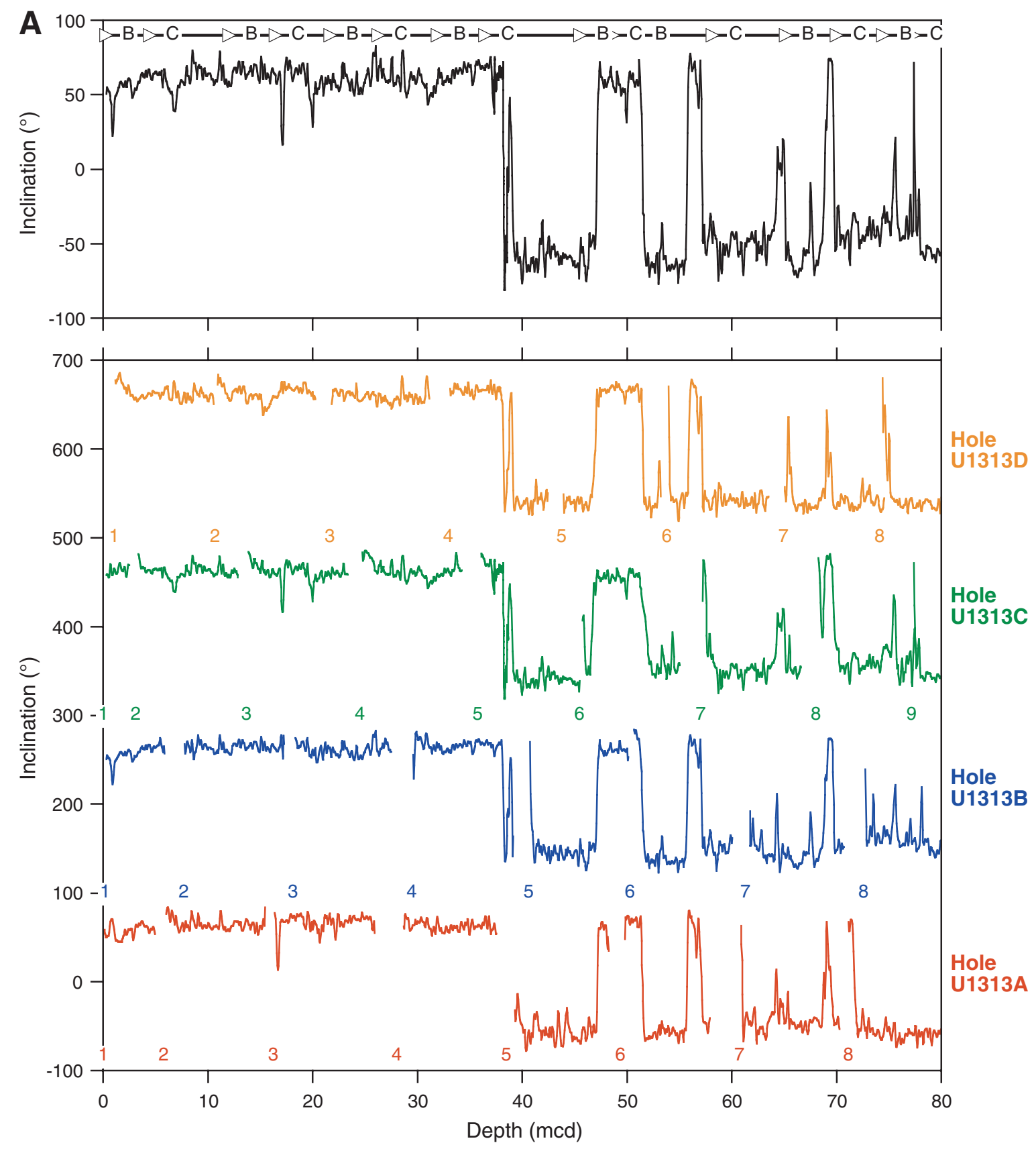


Figure F23 (continued). B. 80-160 mcd.
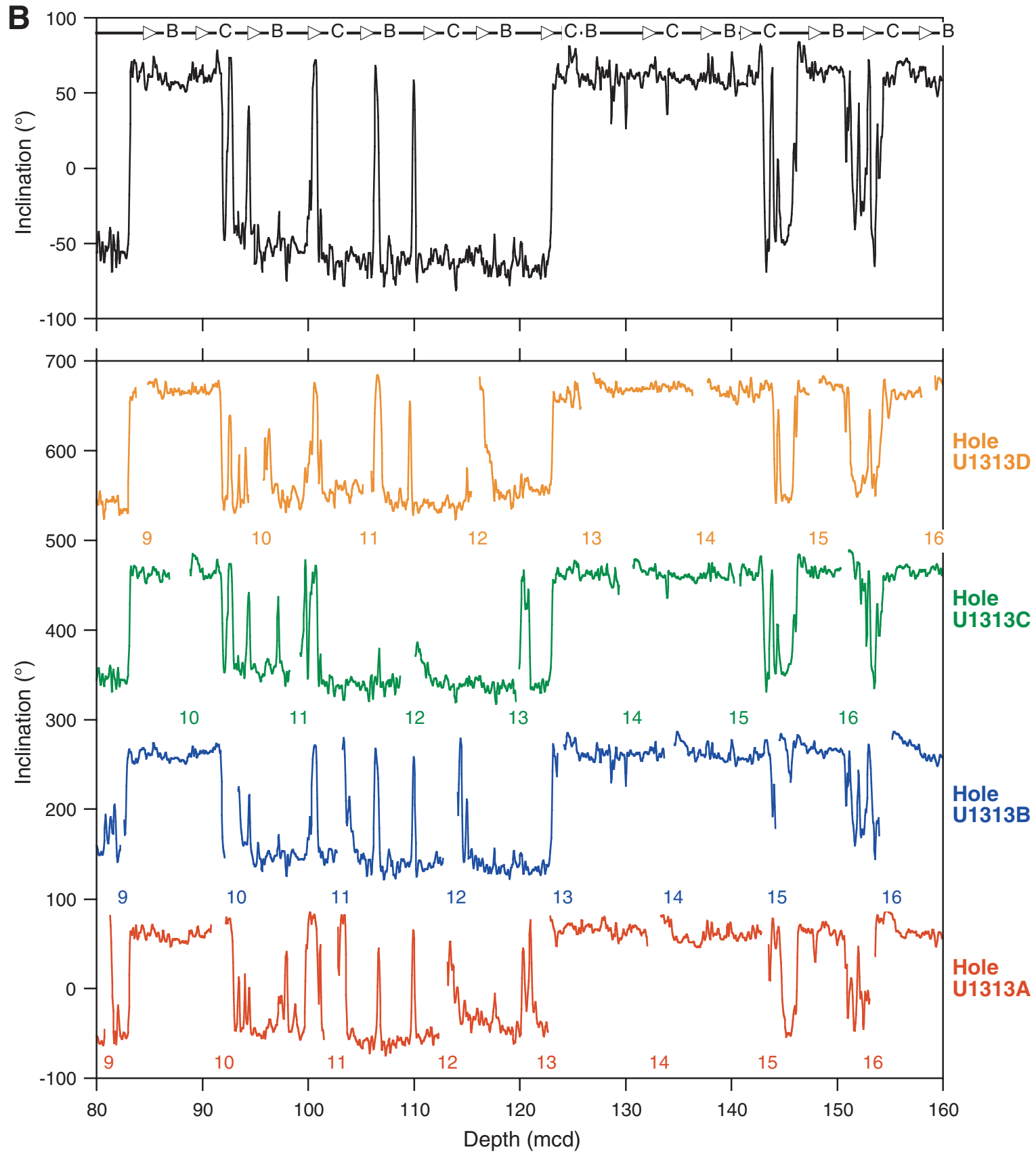
Figure F23 (continued). C. 160-240 mcd.
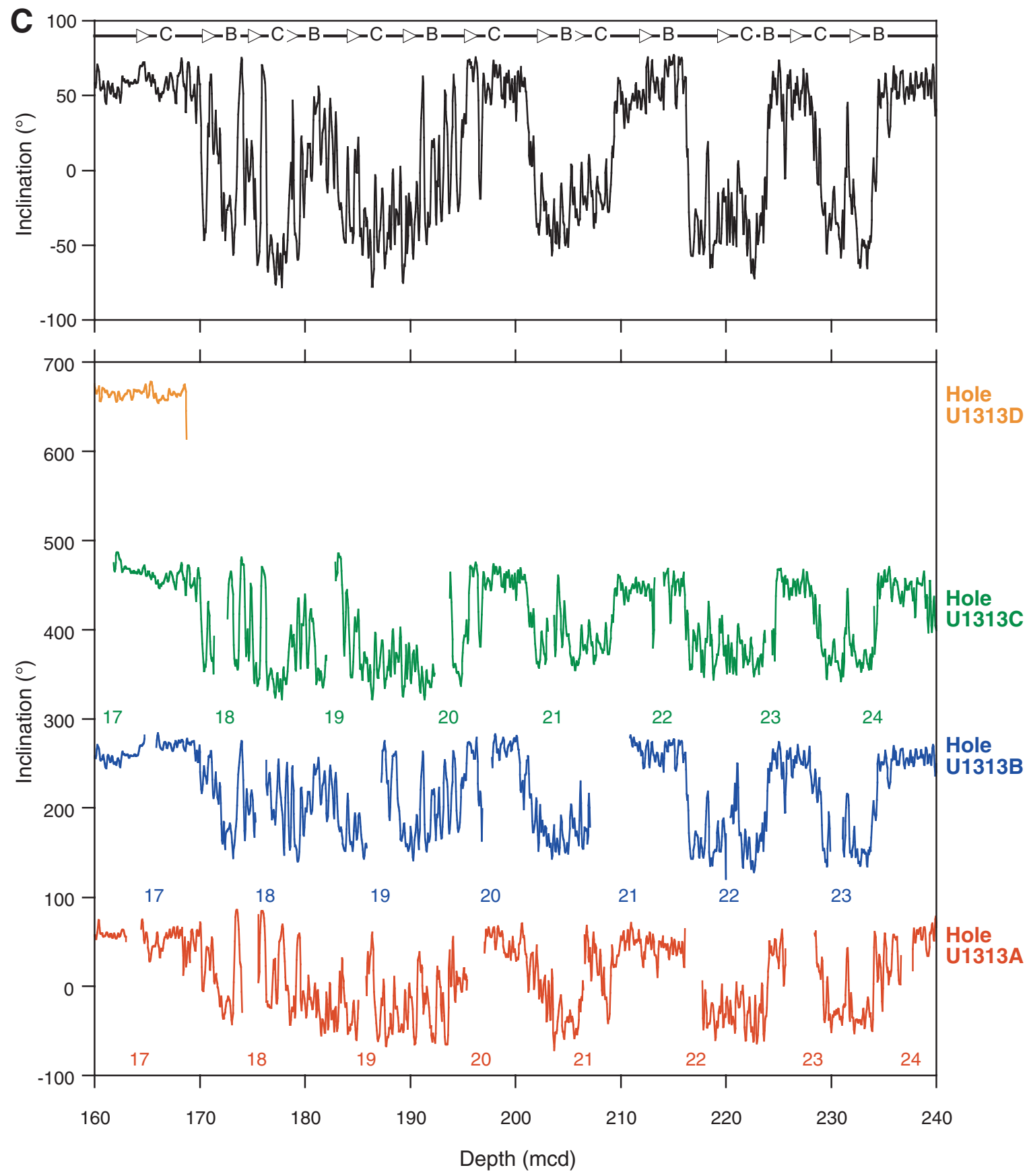
Figure F23 (continued). D. 240-340 mcd.
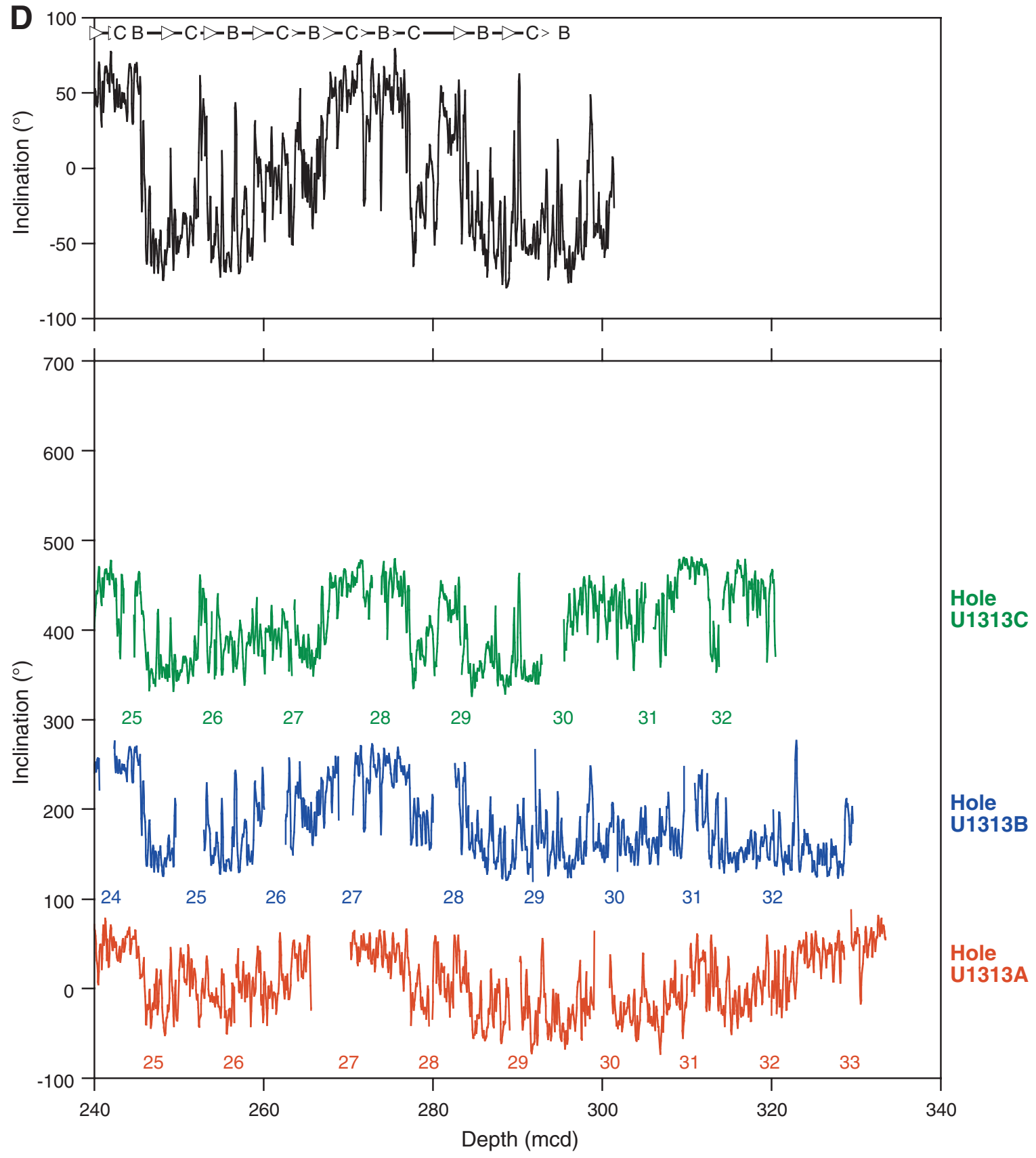
Figure F24. Age model construction for the last 3.4 m.y. at Site U1313. A. Global benthic oxygen isotope stack (Lisiecki and Raymo, 2005). Numbers indicate marine oxygen isotope stages. B. Lightness $\left(\mathrm{L}^{*}\right)$ and magnetic inclination splices for the upper $160 \mathrm{mcd}$. B/M = Bruhnes/Matuyama; Jar. = Jaramillo; C.M. = Cobb Mountain; Old. = Olduvai; and $\mathrm{M} / \mathrm{G}=$ Matuyama/Gauss. C. $\mathrm{L}^{*}$ and benthic oxygen isotope stack vs. age (0-1.7 Ma). D. Sedimentation rates for the time interval 0-1.7 Ma. E. $\mathrm{L}^{*}$ and benthic oxygen isotope stack vs. age (1.7-3.4 Ma). F. Sedimentation rates for the time interval 1.7-3.4 Ma.
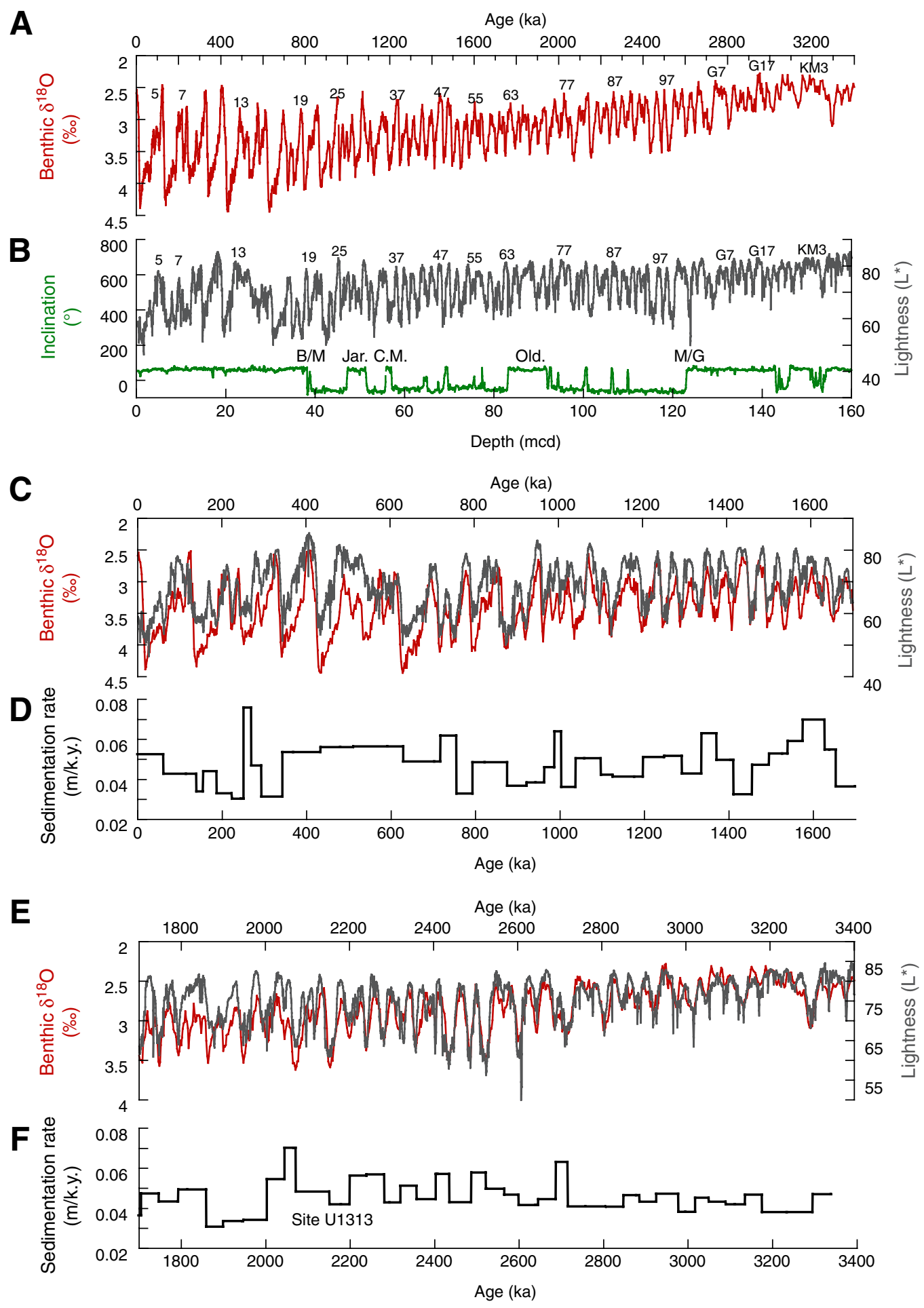
Figure F25. Downhole profiles of chemical constituents of interstitial waters in Hole U1313A. A. Chloride. B. Salinity. C. Alkalinity. D. pH. E. Sodium. F. Potassium. G. Magnesium. H. Calcium. I. Iron. J. Boron. K. Barium (see text for calculation). L. Lithium. M. Manganese. N. Strontium. O. Silica. P. Sulfate and ammonium.
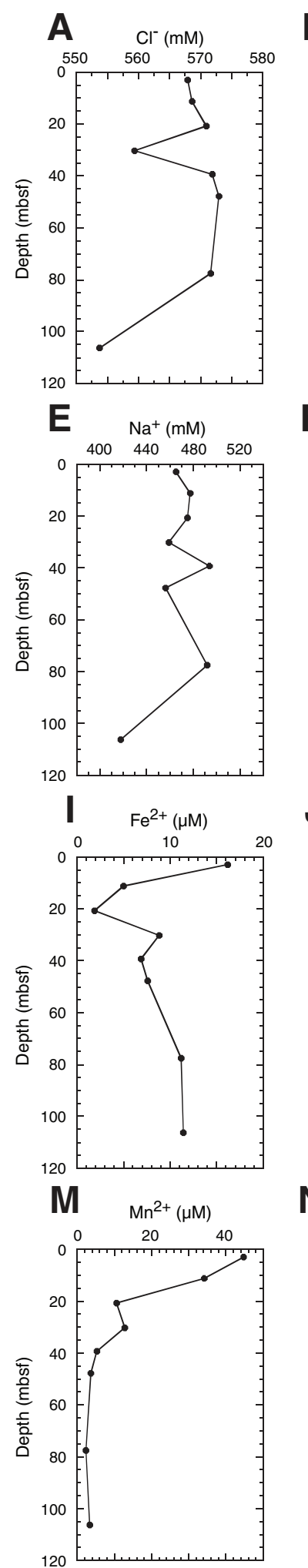

B Salinity $(\mathrm{g} / \mathrm{kg}) \quad$ C

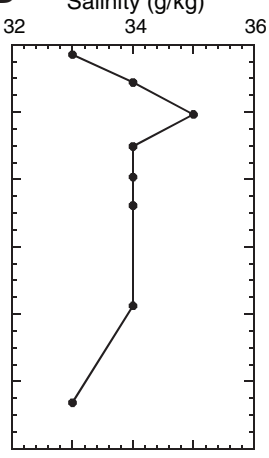

$\mathbf{F}$
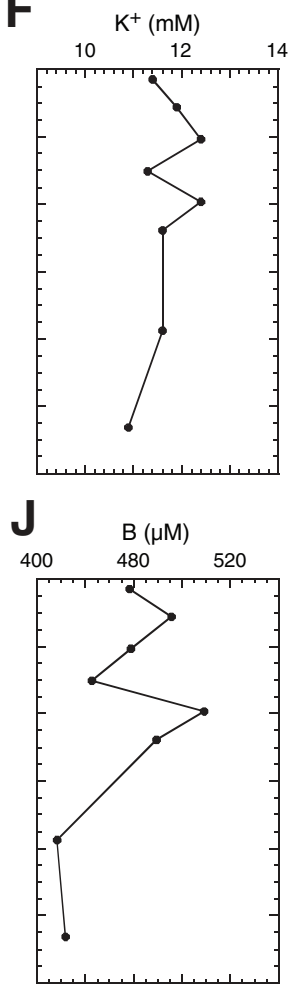

$\mathbf{N}$

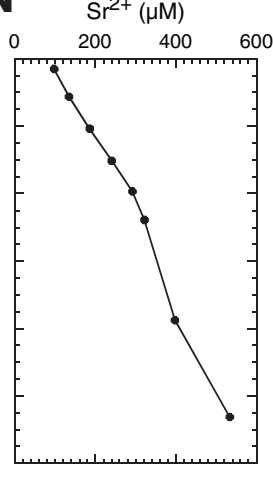

C

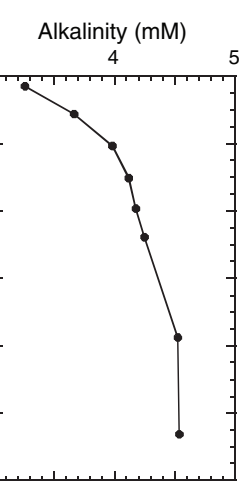

G

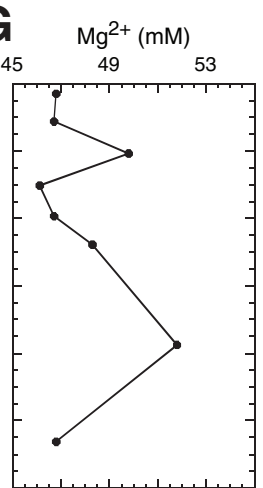

K
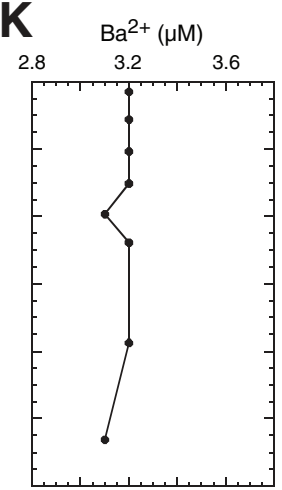

0

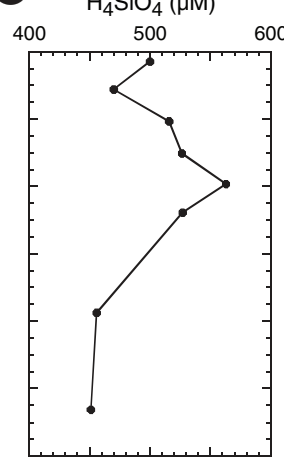

D

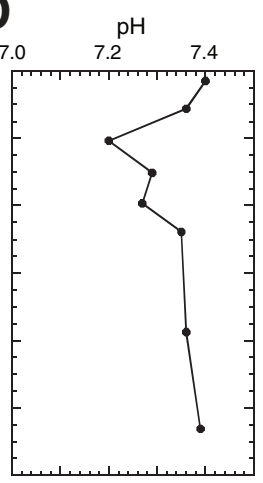

H

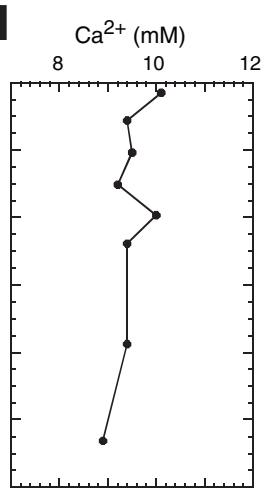

L $\quad \mathrm{Li}^{+}(\mu \mathrm{M})$

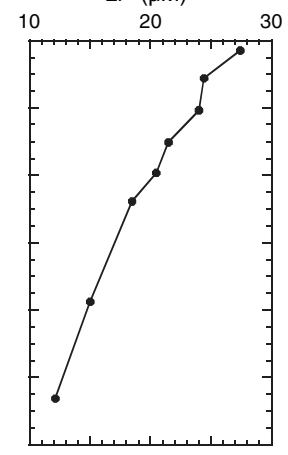

$\mathbf{P}$

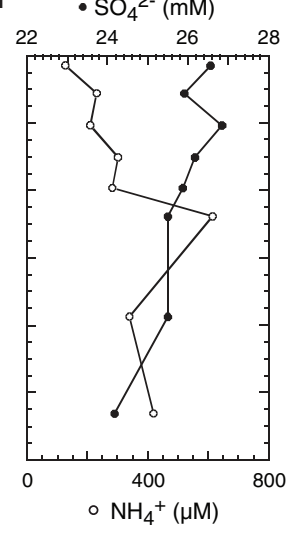


Figure F26. Headspace gas concentrations in Hole U1313A.

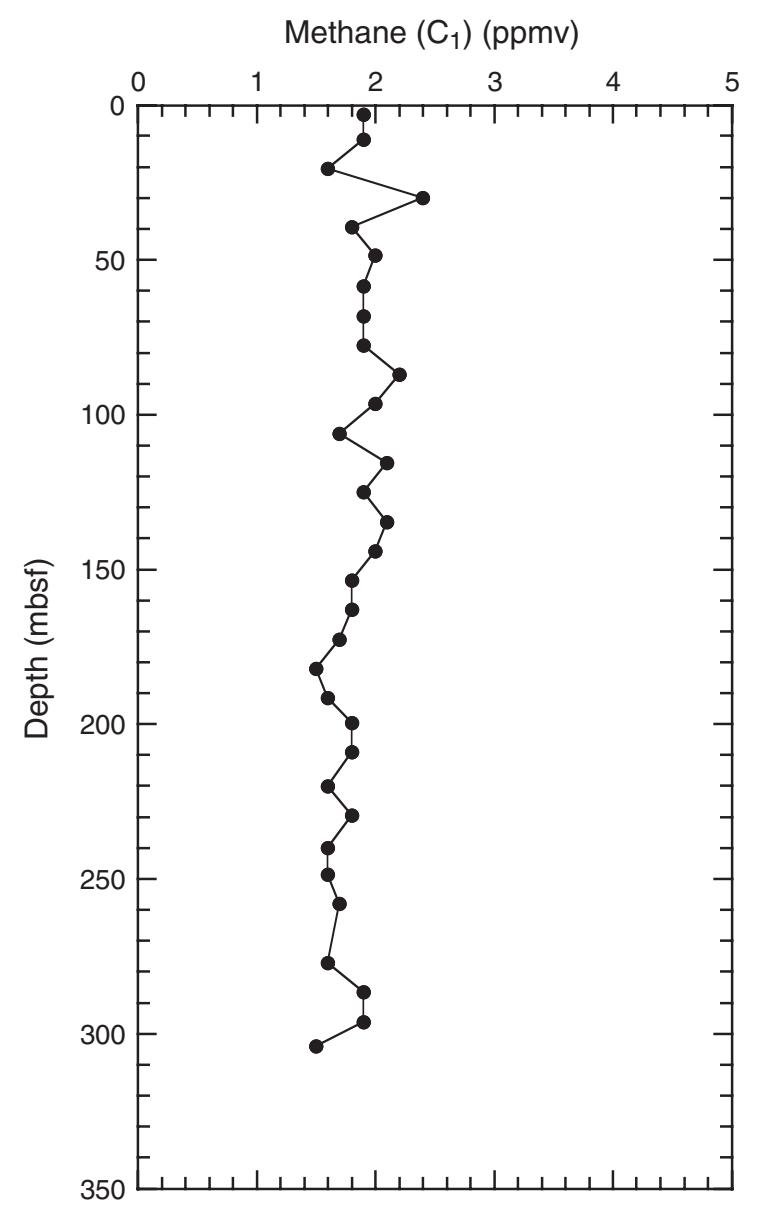


Figure F27. Calcium carbonate content and color reflectance $\left(\mathrm{L}^{*}\right)$ for Hole $\mathrm{U} 1313 \mathrm{~A}$ and $\mathrm{CaCO}_{3}$ contents at Site 607. Main distinctive patterns of the $\mathrm{CaCO}_{3}$ record in Hole U1313A are marked by boxes and the respective averages indicated by solid lines.

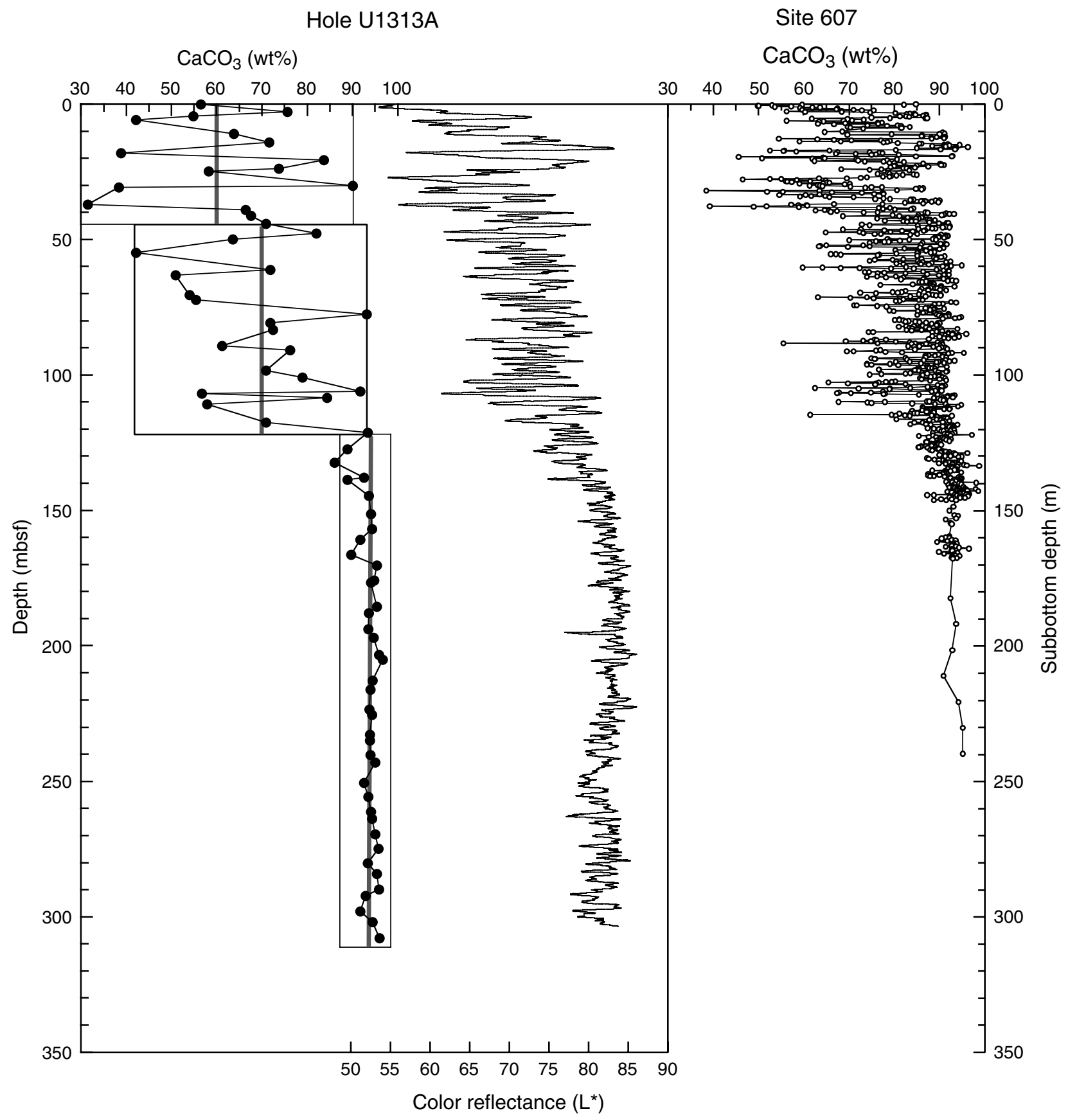


Figure F28. Total organic carbon (TOC) and total nitrogen (TN) in Hole U1313A.
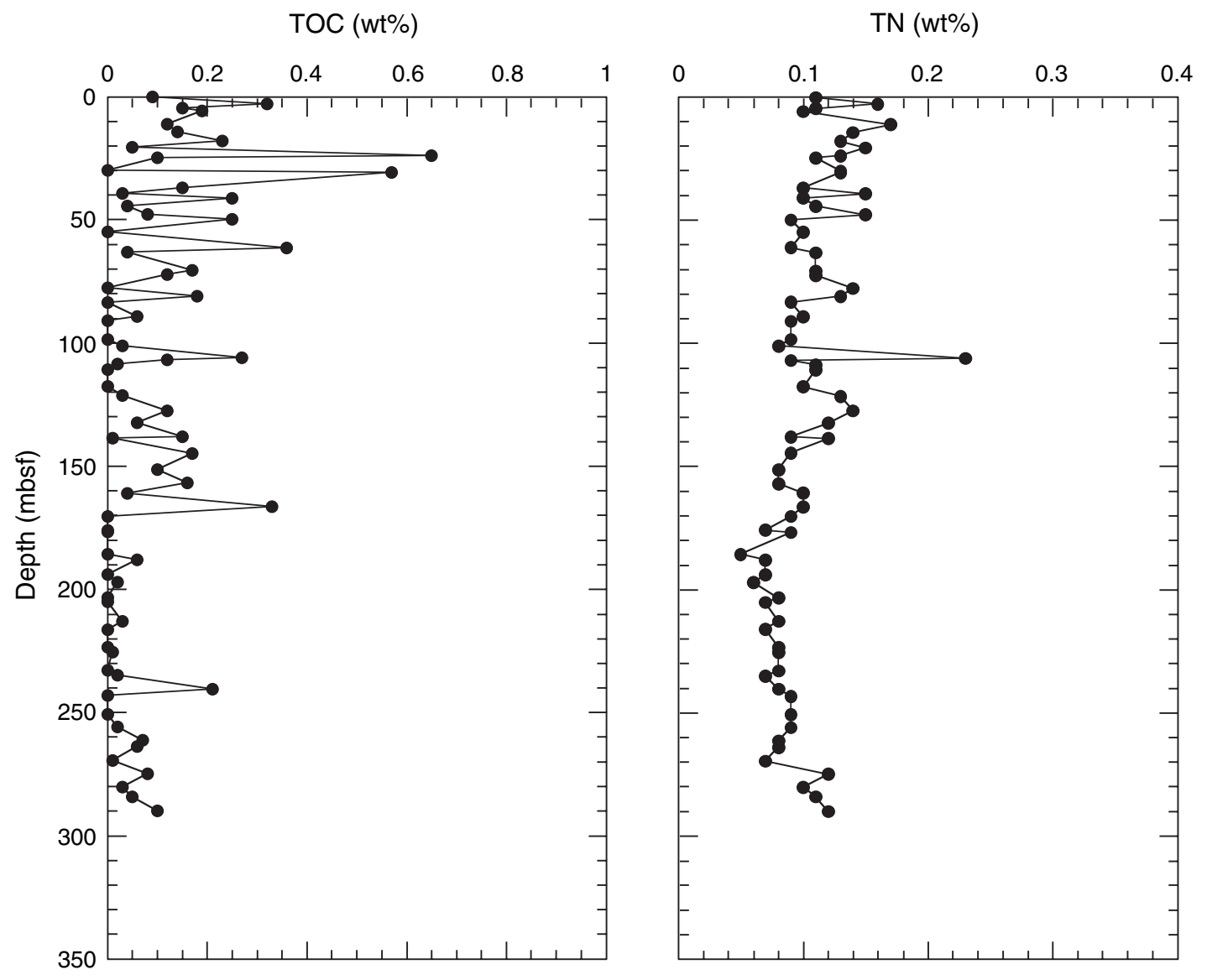
Figure F29. GC-FID trace of solvent-extractable compounds for Sample 306-U1313A-6H-4, 145-150 cm. Numbers above or below peaks refer to carbon atom numbers of $n$-alkanes or long-chain alkenones, respectively. Number of double bonds for the $C_{37}$ alkenones is given as $: 4,: 3$, and $: 2$. $X=$ contaminant.

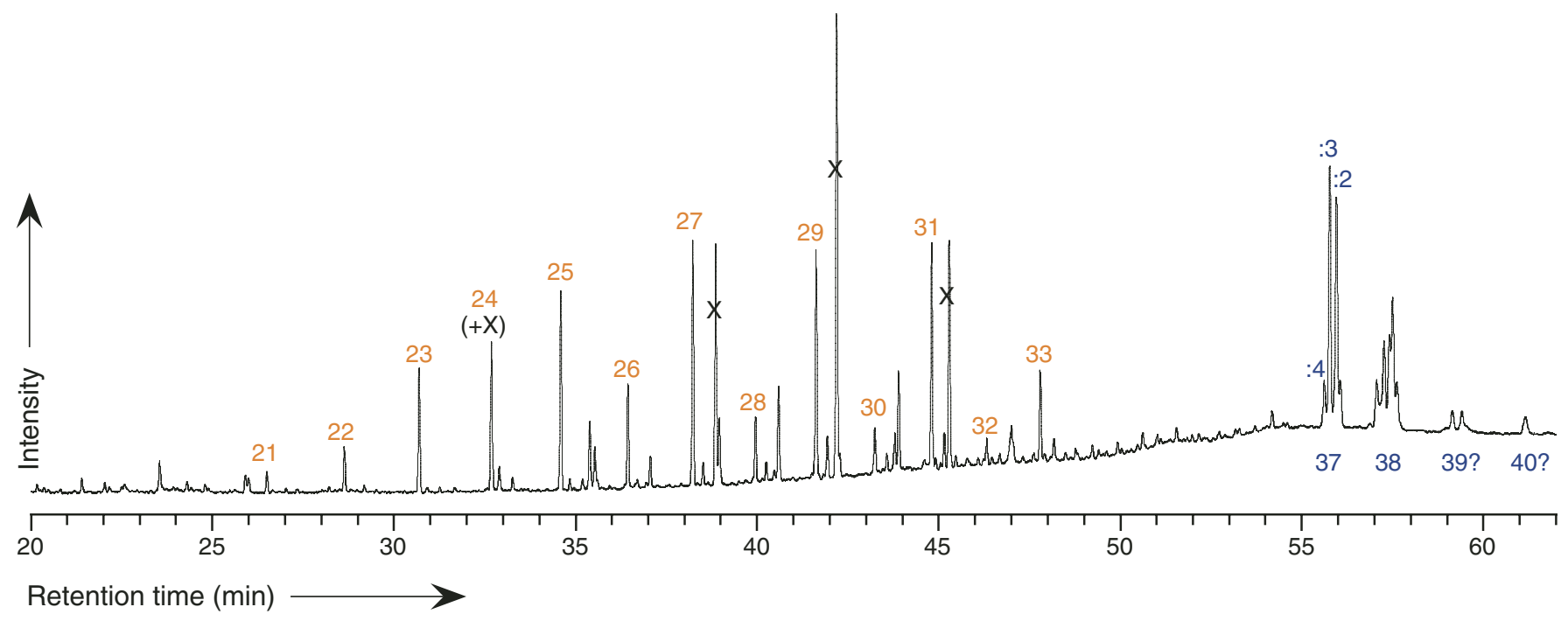


Figure F30. Proportions of marine- and terrigenous-derived extractable organic matter (EOM) in sediments from Hole U1313A as estimated from the ratios of $\mathrm{C}_{27}, \mathrm{C}_{29}$, and $\mathrm{C}_{31} n$-alkanes to $\mathrm{C}_{37}$ alkenones. Note that the bars are equally spaced and do not represent the actual sample position in a depth profile.

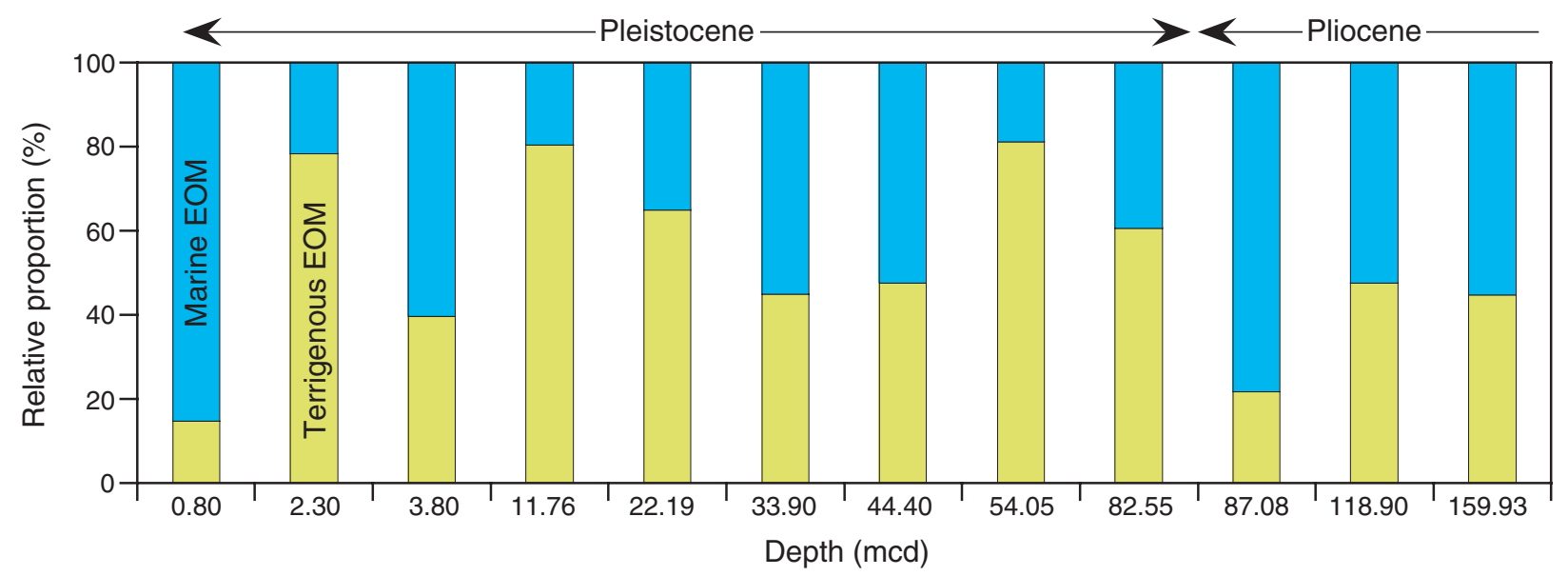


Figure F31. Alkenone-derived sea-surface temperature (SST) in Hole U1313A compared to the global benthic $\delta^{18} \mathrm{O}$ stack (Lisiecki and Raymo, 2005).

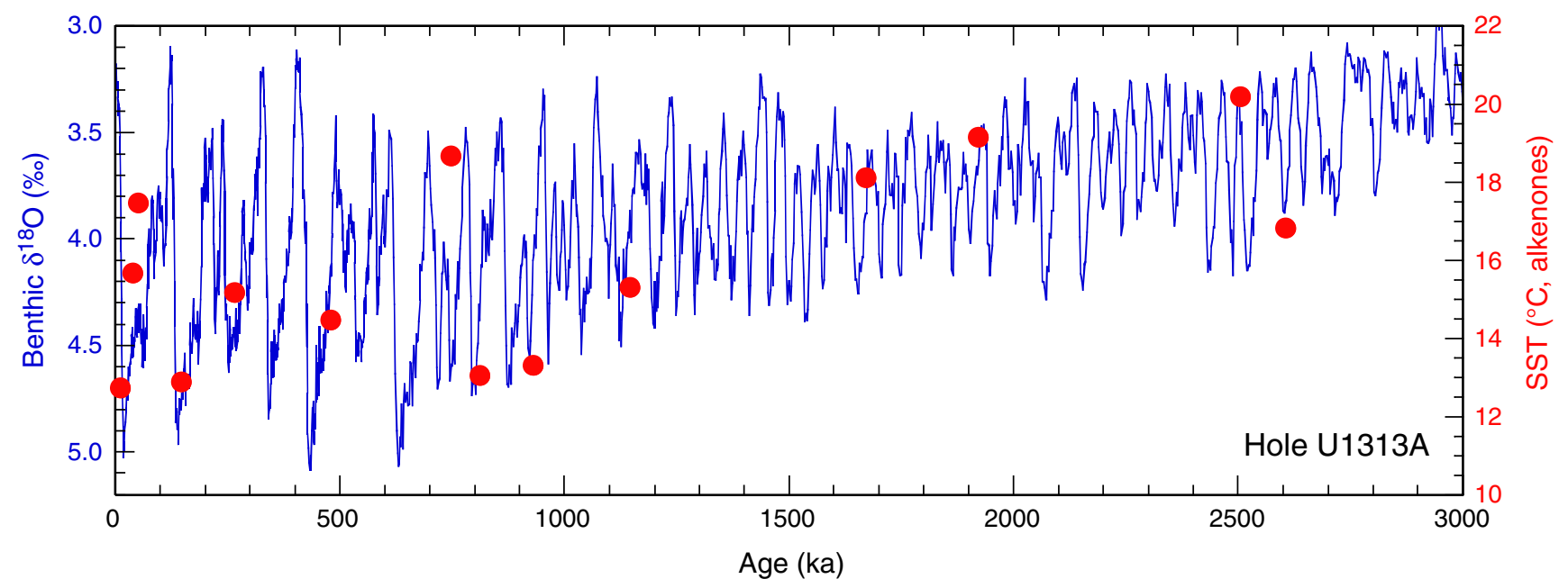


Figure F32. Magnetic susceptibility records. Black $=$ MST, red $=$ MSCL. Multiply values by $6 \times 10^{-5}$ to obtain SI units.

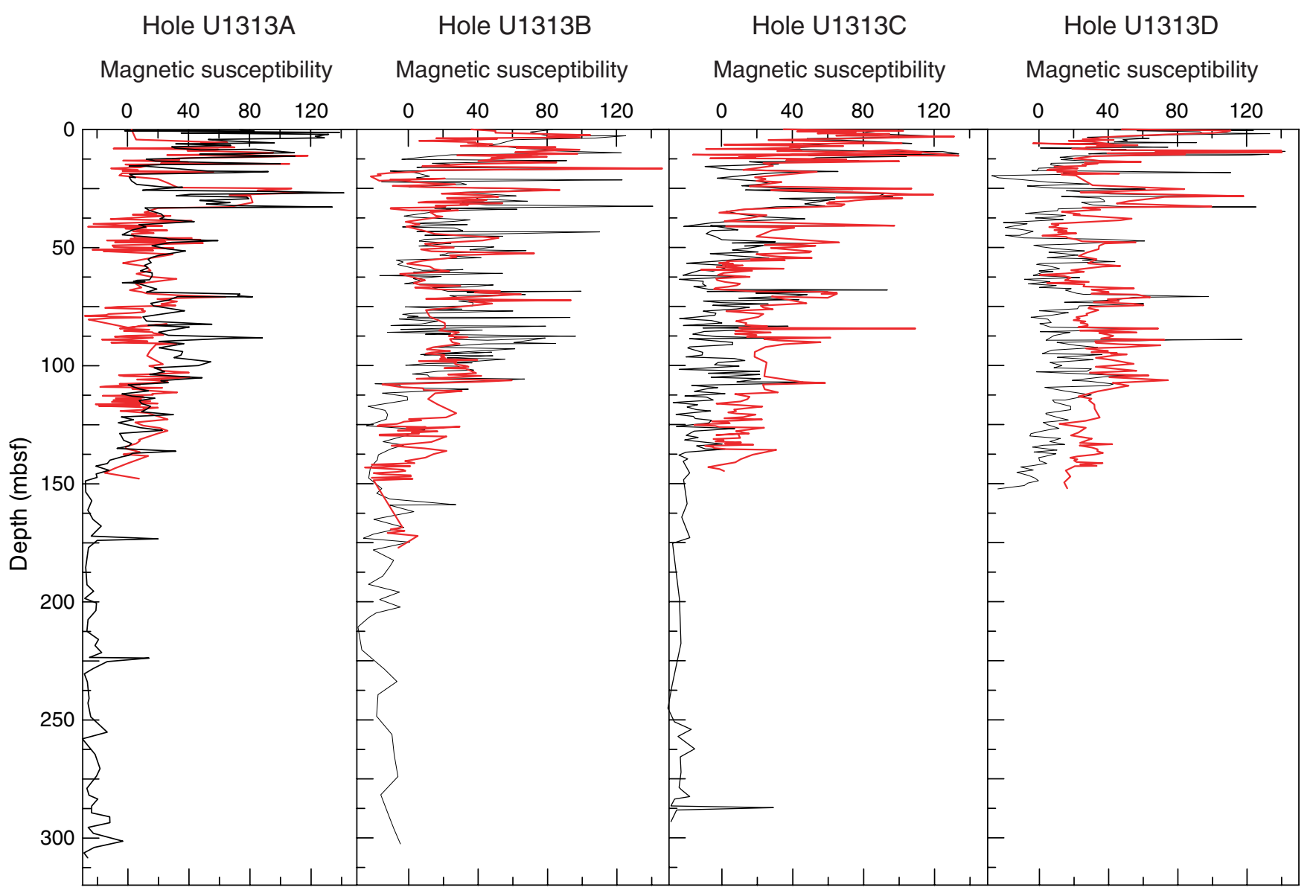


Figure F33. Combined GRA density measurements from the MST.

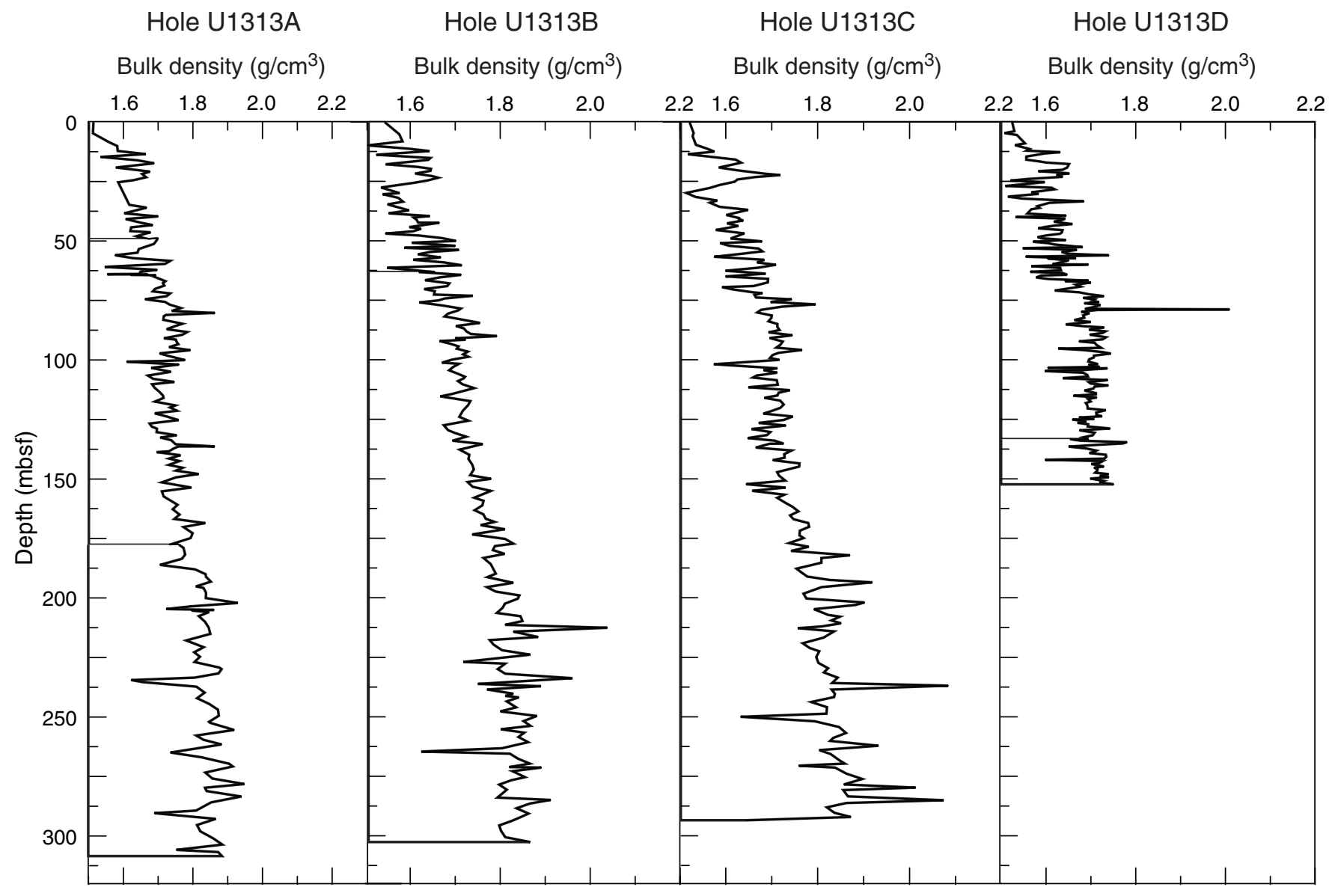


Figure F34. Porosity and density values for Hole U1313A.

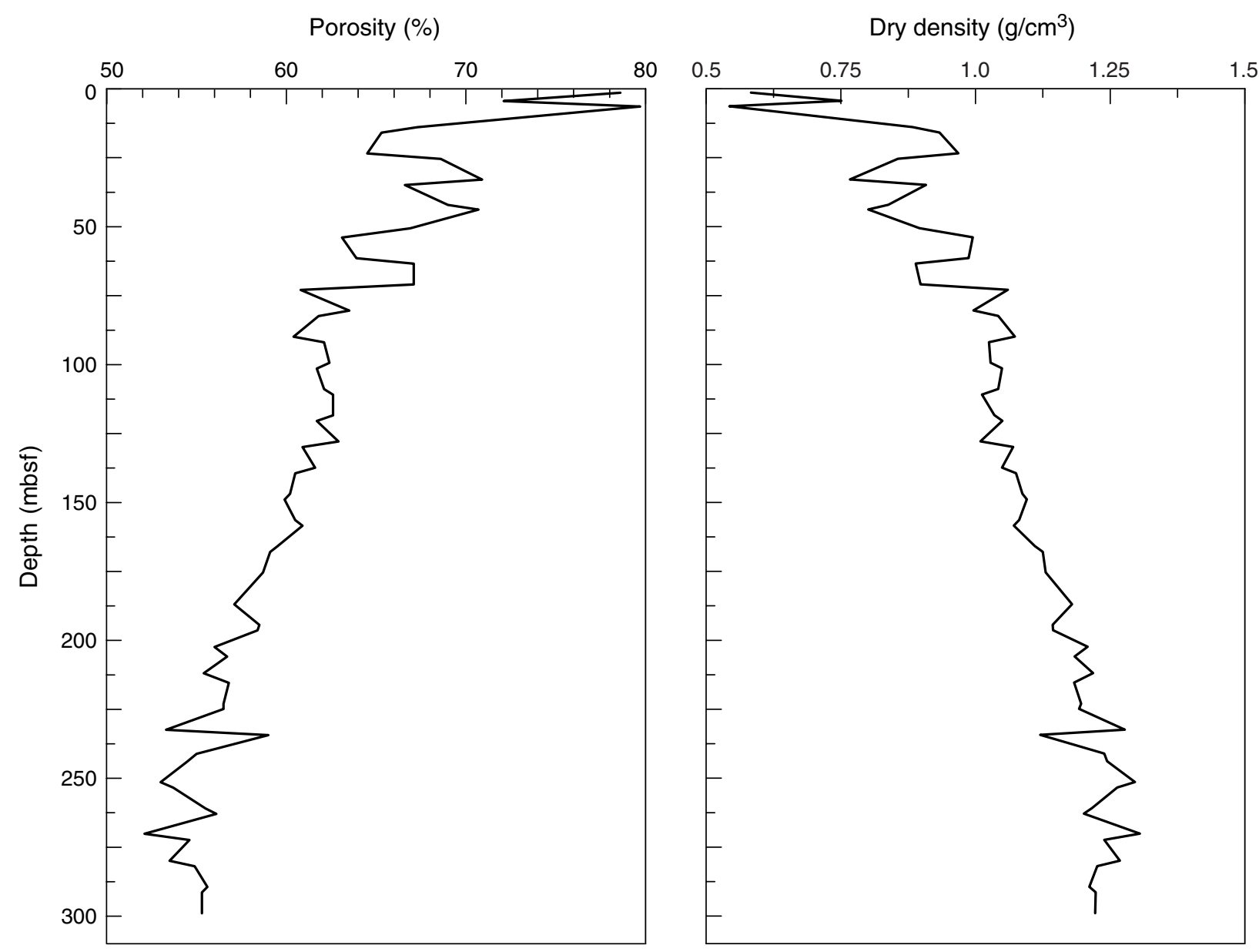


Figure F35. Natural gamma radiation (NGR) from the MST.

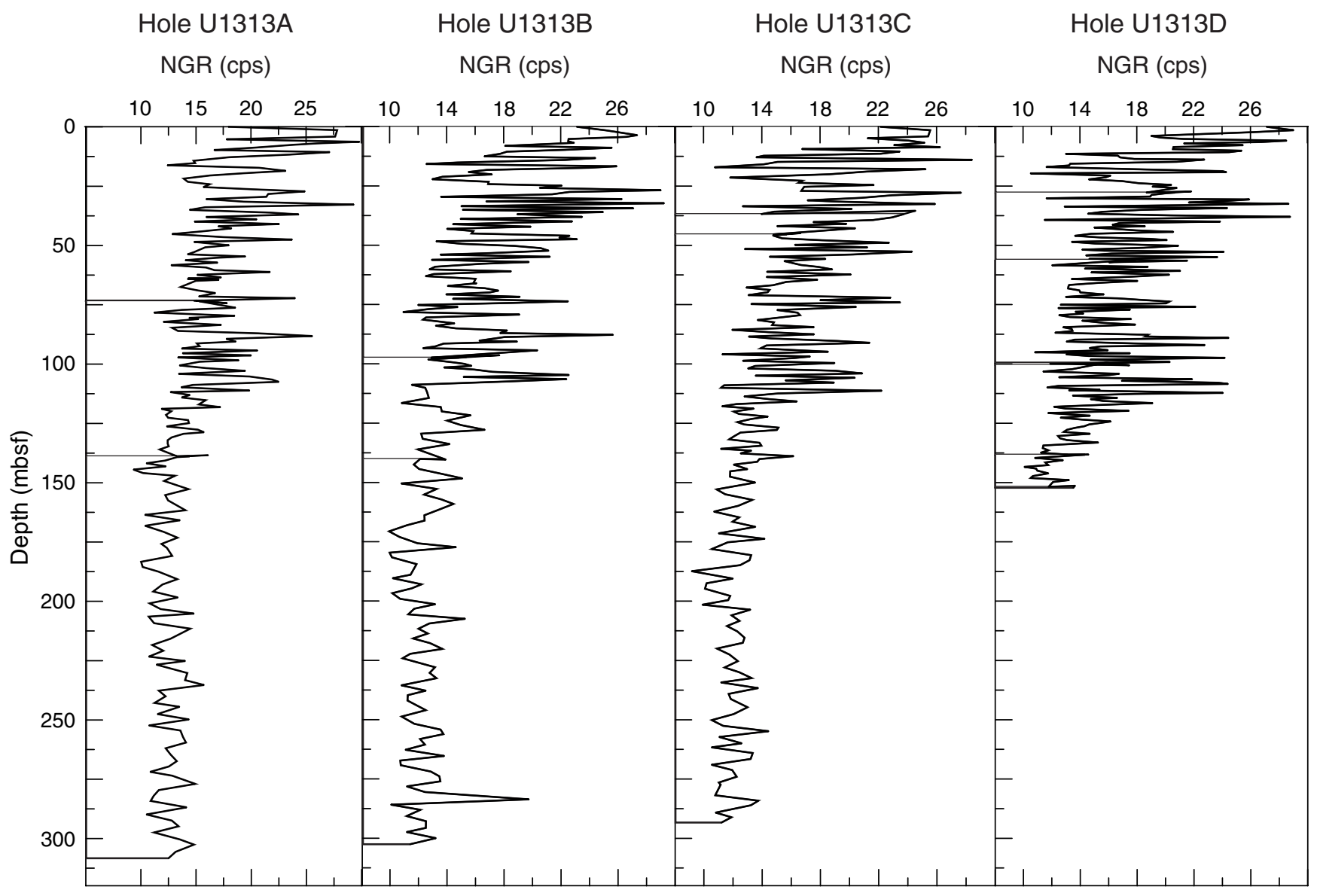


Figure F36. Downhole $P$-wave velocity for Holes U1313A and U1313B from multisensor track (MST) and $P$ wave velocity sensor (PWS).

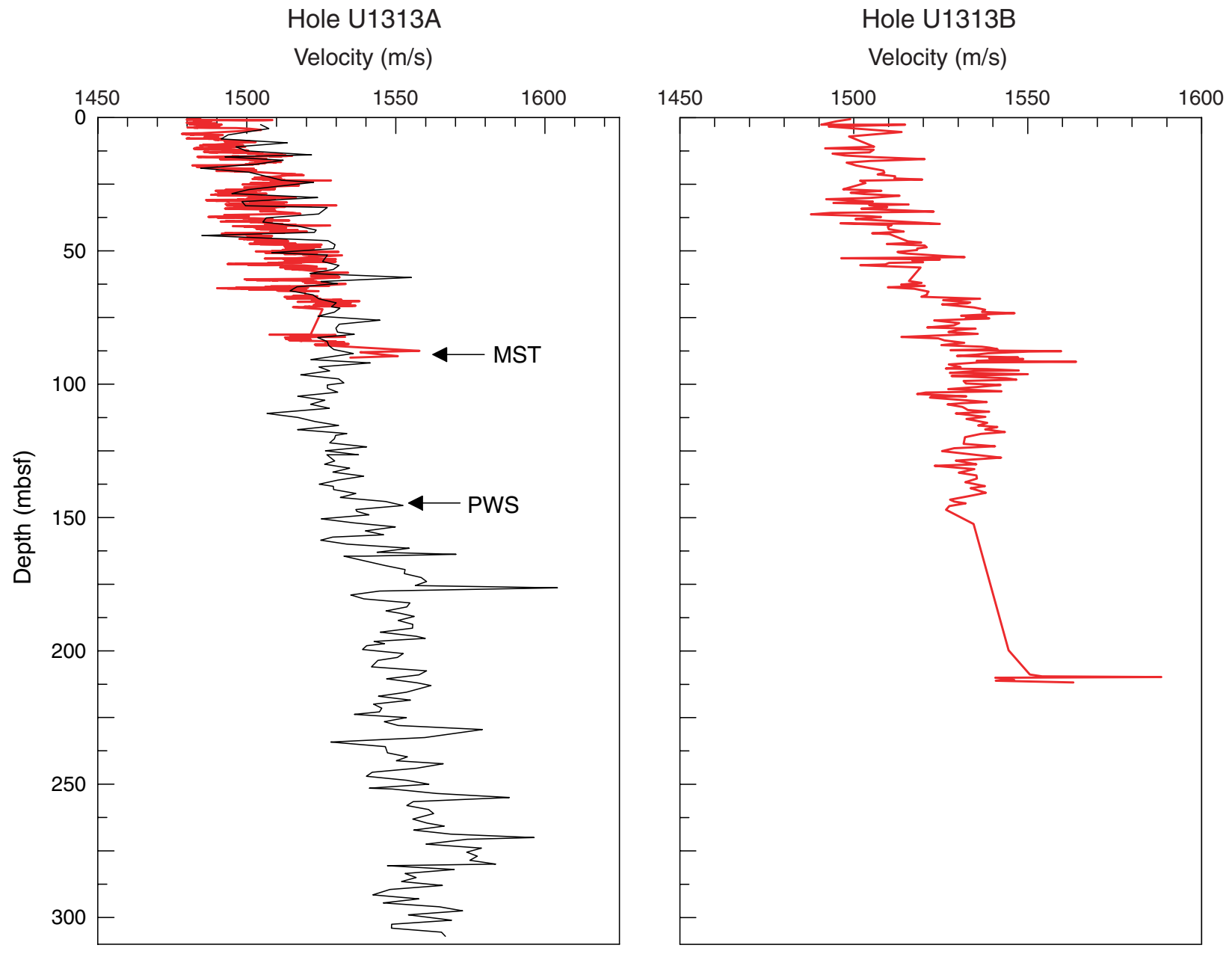


Figure F37. Details of important depths recorded during logging tool string deployment in Hole U1313B. Triple combination (triple combo) = DIT-E + APS + HNGS + HLDS tools. See "Downhole measurements" in the "Site U1312-U1315 methods" chapter for details on tools.

Triple combo

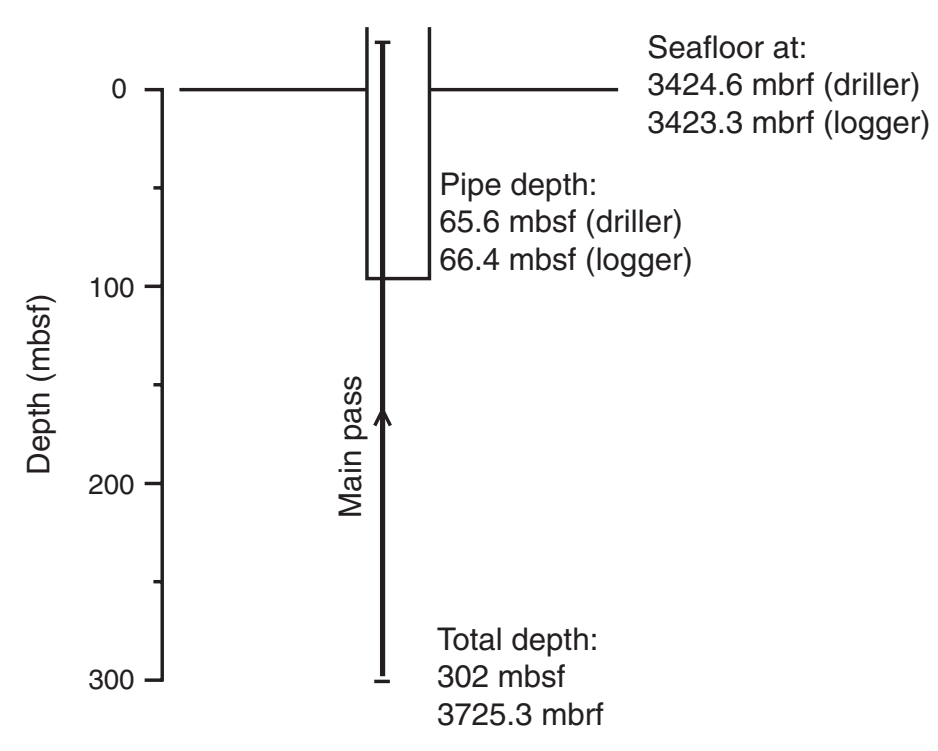


Figure F38. Caliper, porosity, density, electrical resistivity, and photoelectric effect factor (PEF) data for Hole U1313B. IMH $=$ medium induction phasor-processed resistivity, IDPH = deep induction phasor-processed resistivity, SFLU = spherically focused resistivity.
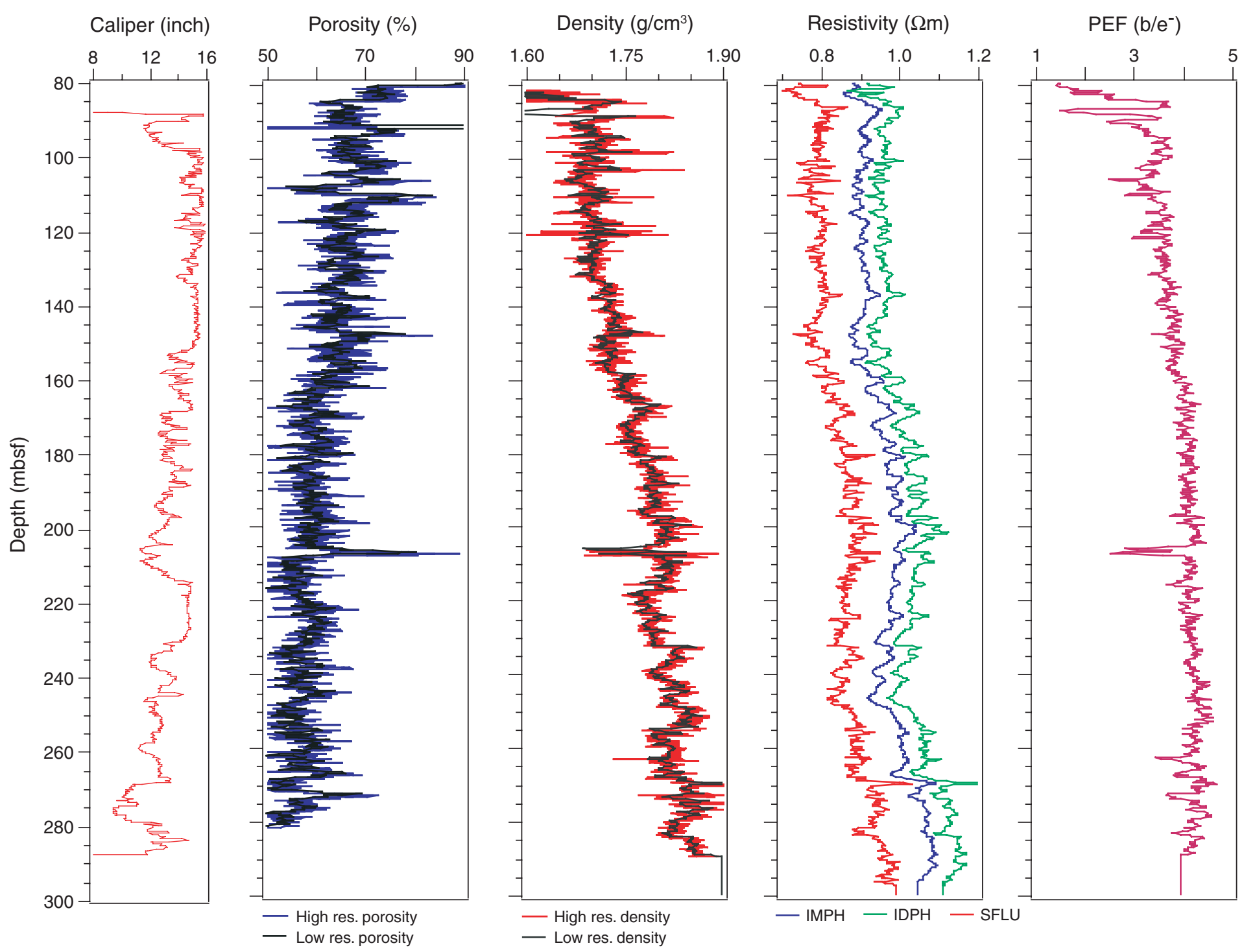
Figure F39. Caliper, total gamma ray (computed gamma ray headspace [HCGR]; Th $+\mathrm{K}$ ) and spectral gamma ray (Hostile Environment Gamma Ray Sonde [HSGR]), thorium, uranium, and potassium data in Hole U1313B.

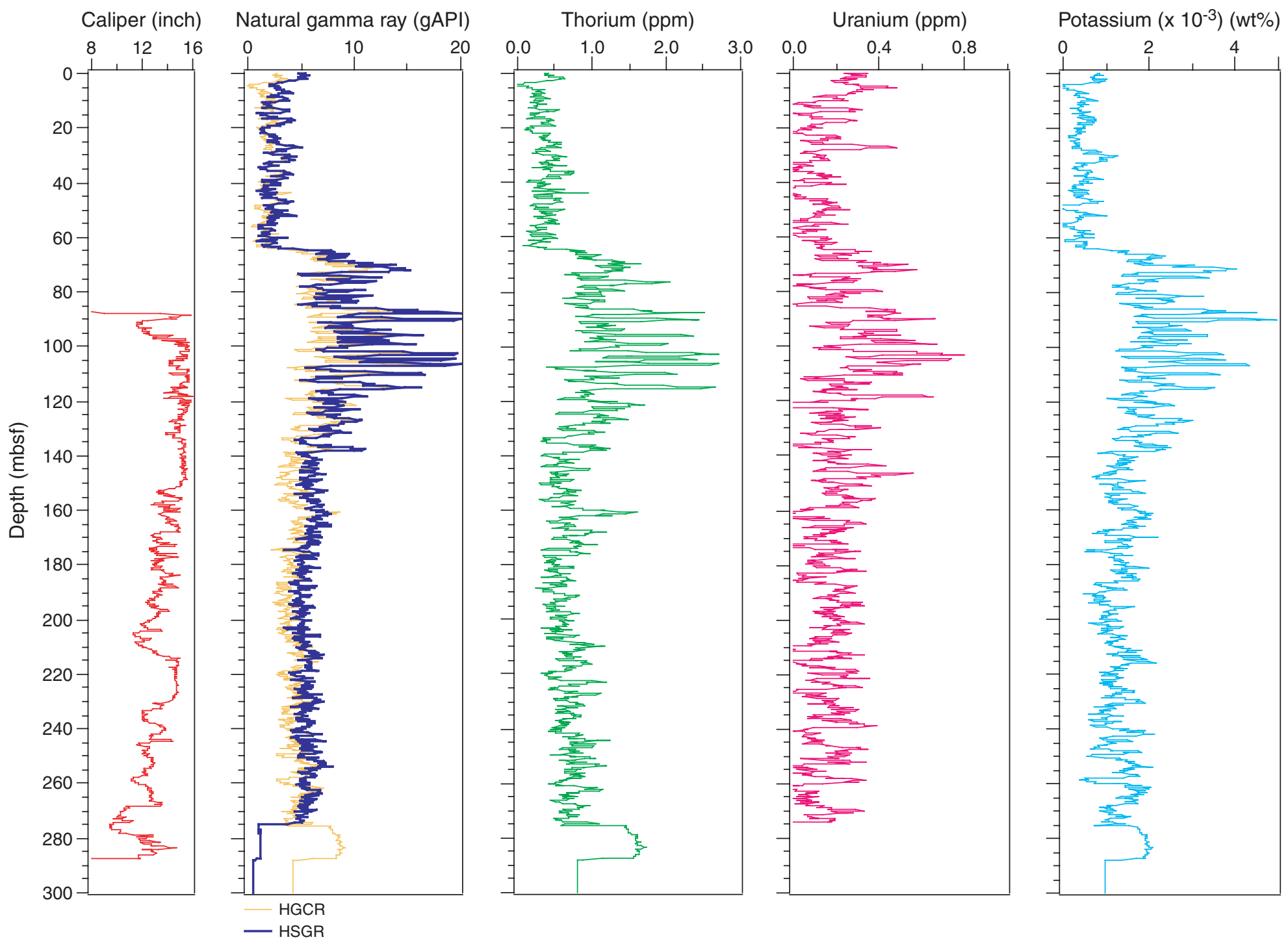


Figure F40. Comparison of core and logging physical properties in Hole U1313B. A. Multisensor track (MST) GRA bulk density (red) and downhole logging HROM bulk density (blue). B. MST natural gamma radiation (NGR; green) and logging total spectral gamma ray (HSGR) NGR (pink).
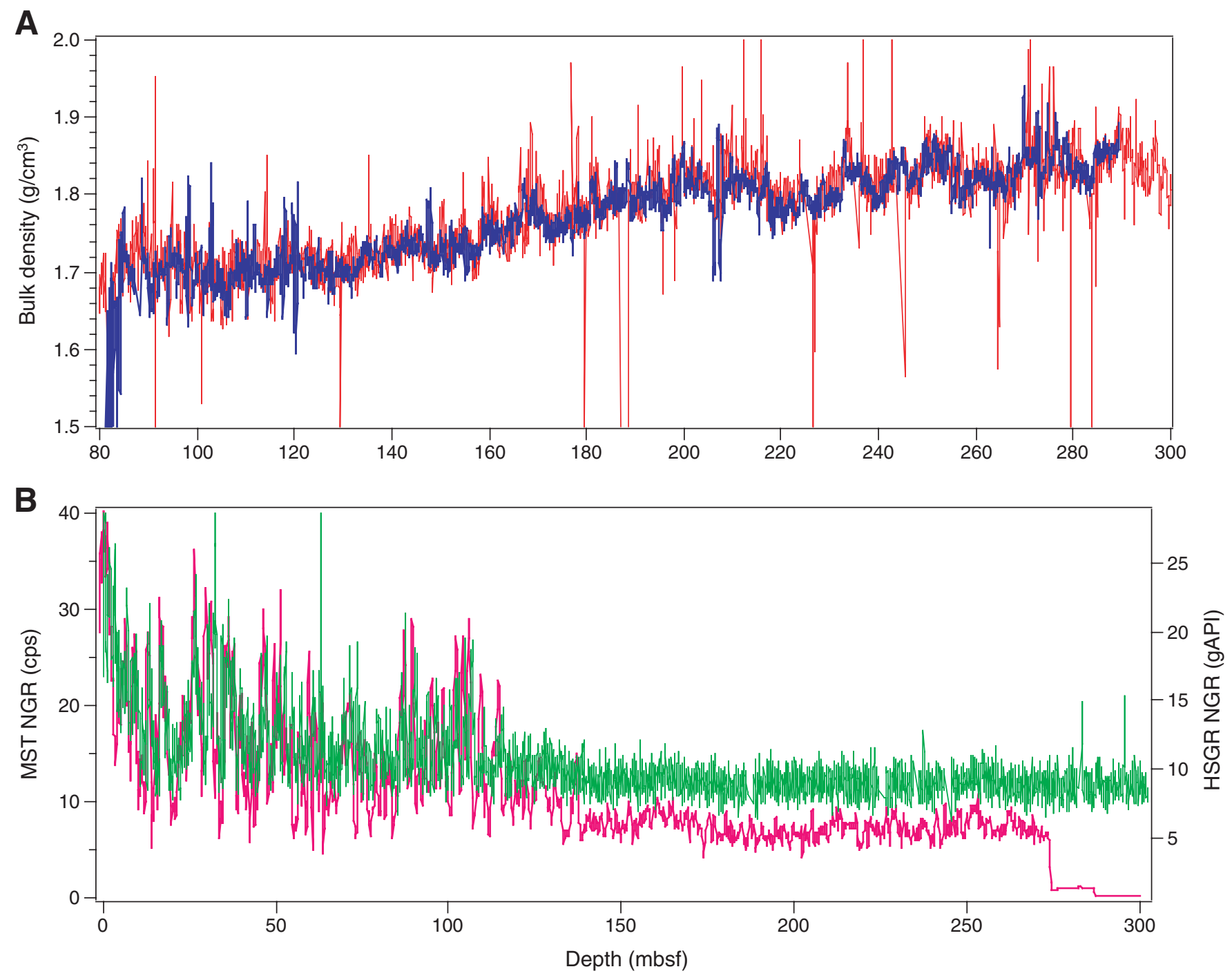
Figure F41. Detailed comparisons of core and logging physical properties from upper $70 \mathrm{~m}$ in Hole U1313B. A. MST core (red; cps) and logging (black; gAPI) natural gamma radiation (NGR). B. Archive multisensor track core lightness $\left({ }^{*} \mathrm{~L} ; \sim \mathrm{CaCO}_{3}\right.$ ) and logging total spectral gamma ray (HSGR) NGR.

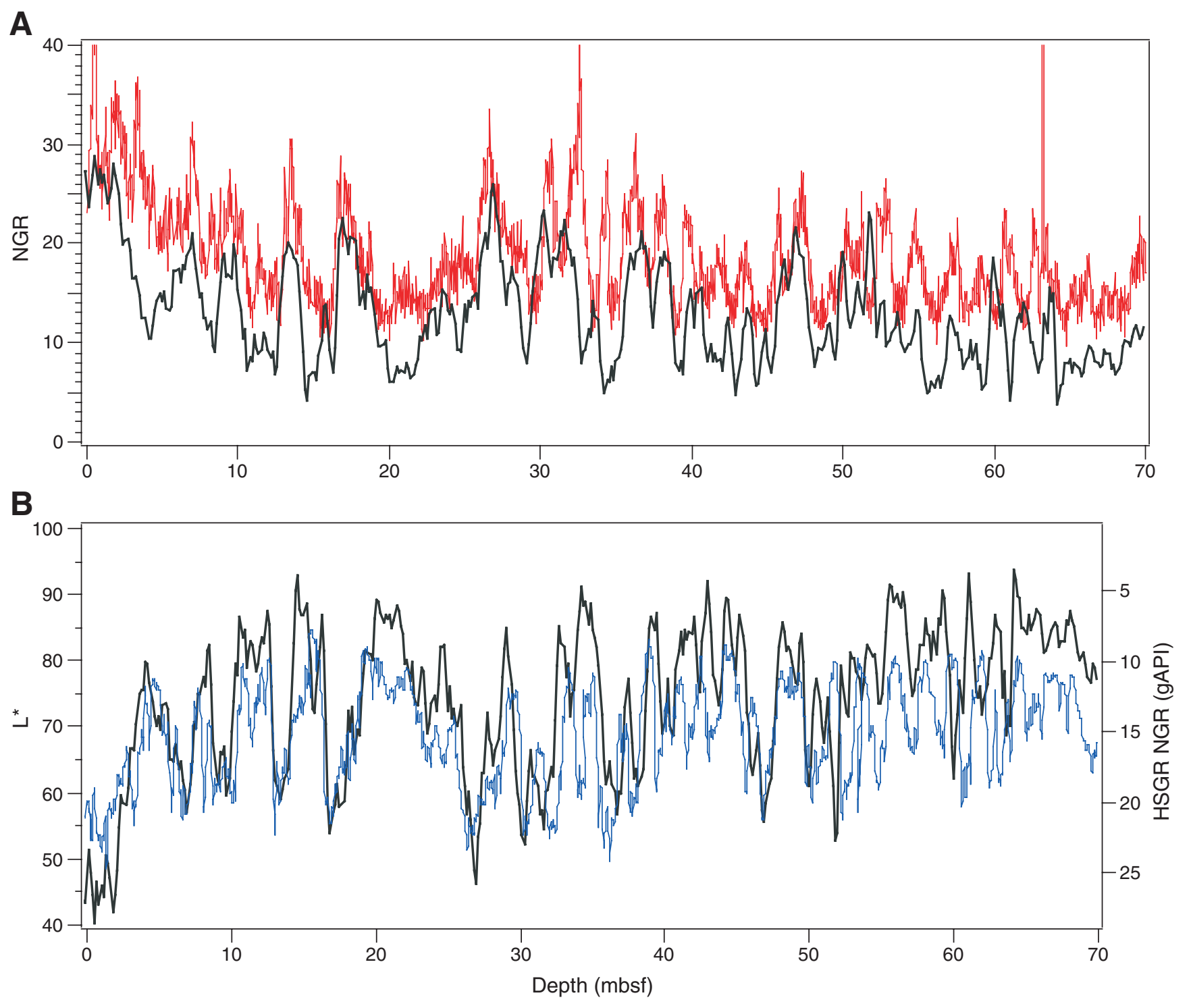


Figure F42. Linear correlation of logging natural gamma radiation (NGR; total spectral gamma ray [HSGR]; black) in Hole U1313B and benthic oxygen isotope stack (red) over last 5.4 m.y. (Lisiecki and Raymo, 2005). Both data sets are shown with scales inverted so that warm interglacials/low gamma ray (i.e., low $\mathrm{Th}=$ low clay) intervals are shown as prominent peaks. The correlation has only two tie points at 0 and 5.4 Ma with no stretching or squeezing of logging data depths.

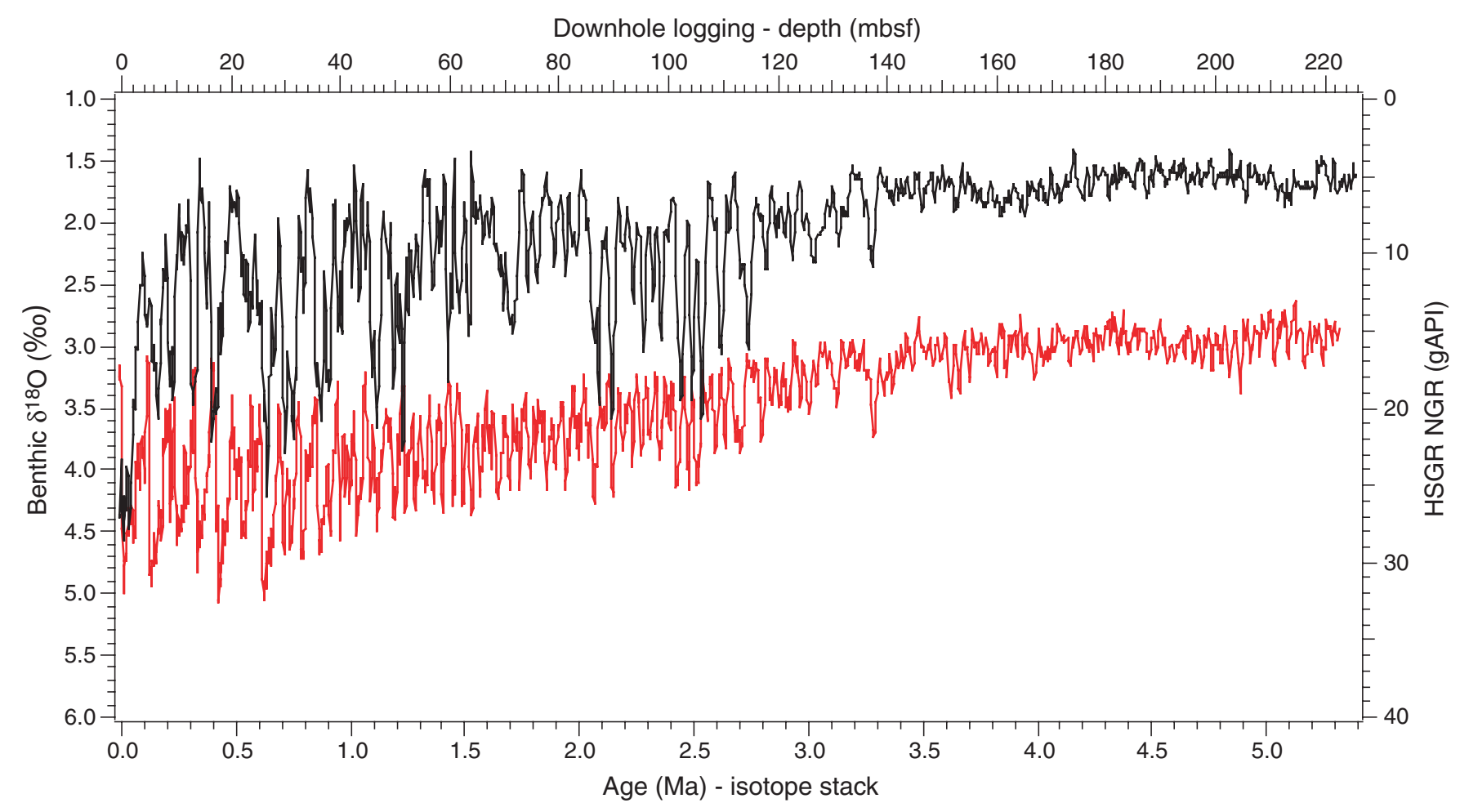


Figure F43. Expanded linear correlation shown in Figure F42 of logging gamma radiation (black) and benthic oxygen isotope stack (red) in Hole U1313B at four intervals. Vertical scales of both isotopes and gamma radiation are adjusted for plotting purposes for a given interval as necessary. Note the fidelity in detail of gamma ray record regardless of signal amplitude over almost the entire $5.4 \mathrm{~m}$.y. record of oxygen isotopes. A. 0-1 Ma. B. 0.85-2.4 Ma. (Continued on next page.)
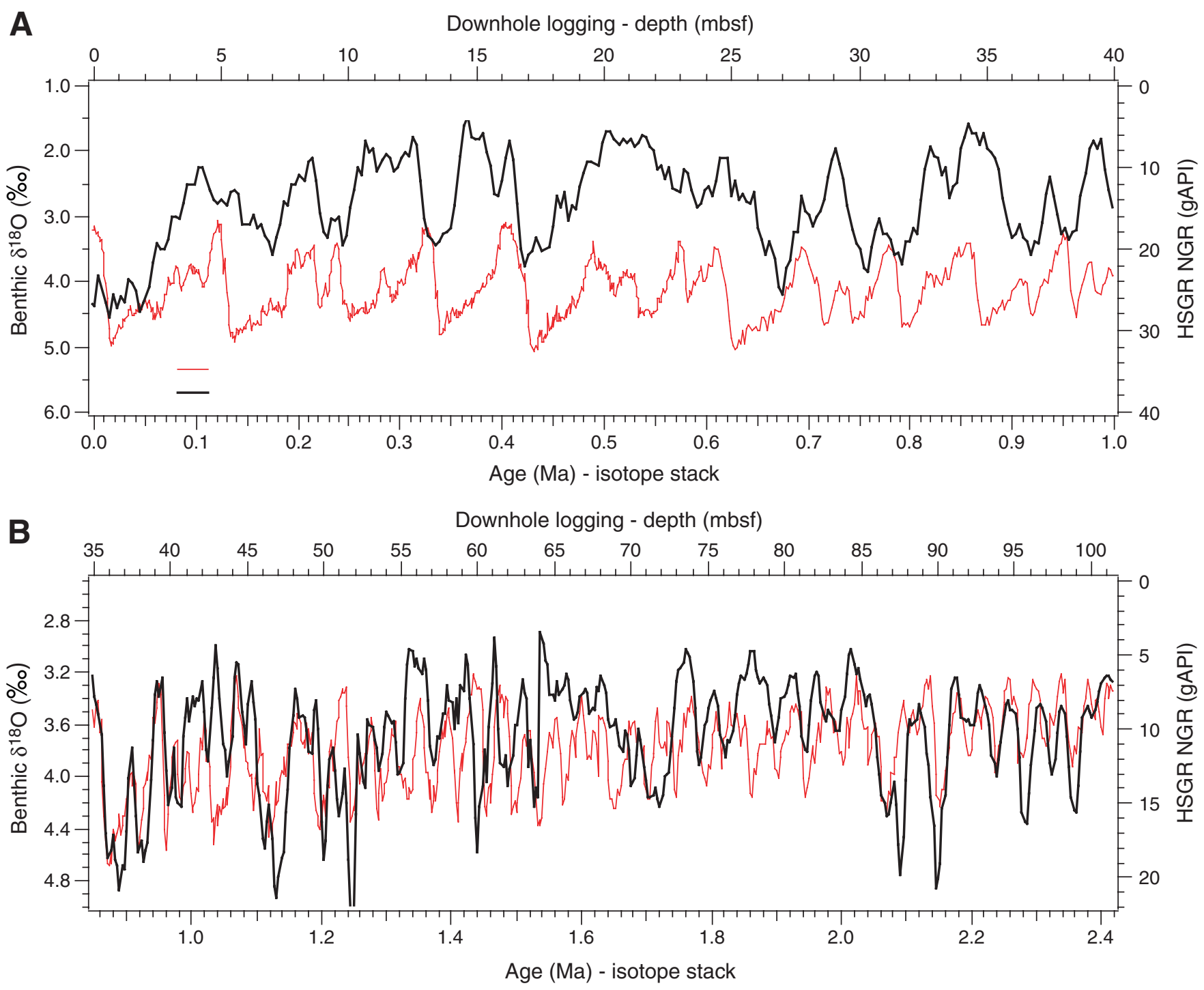
Figure F43 (continued). C. 2.4-3.8 Ma. D. 3.8-5.4 Ma.
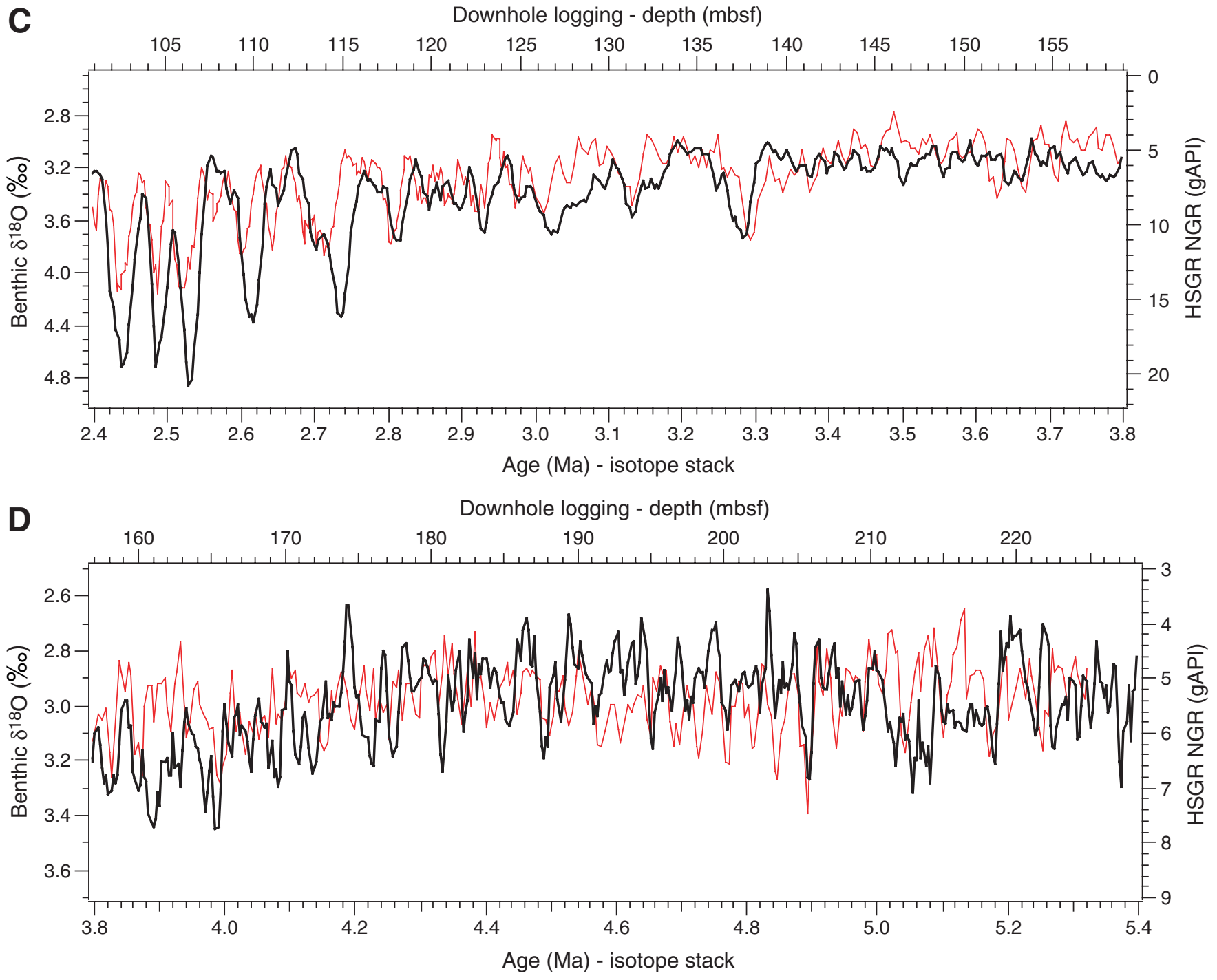
Table T1. Coring summary, Site U1313.

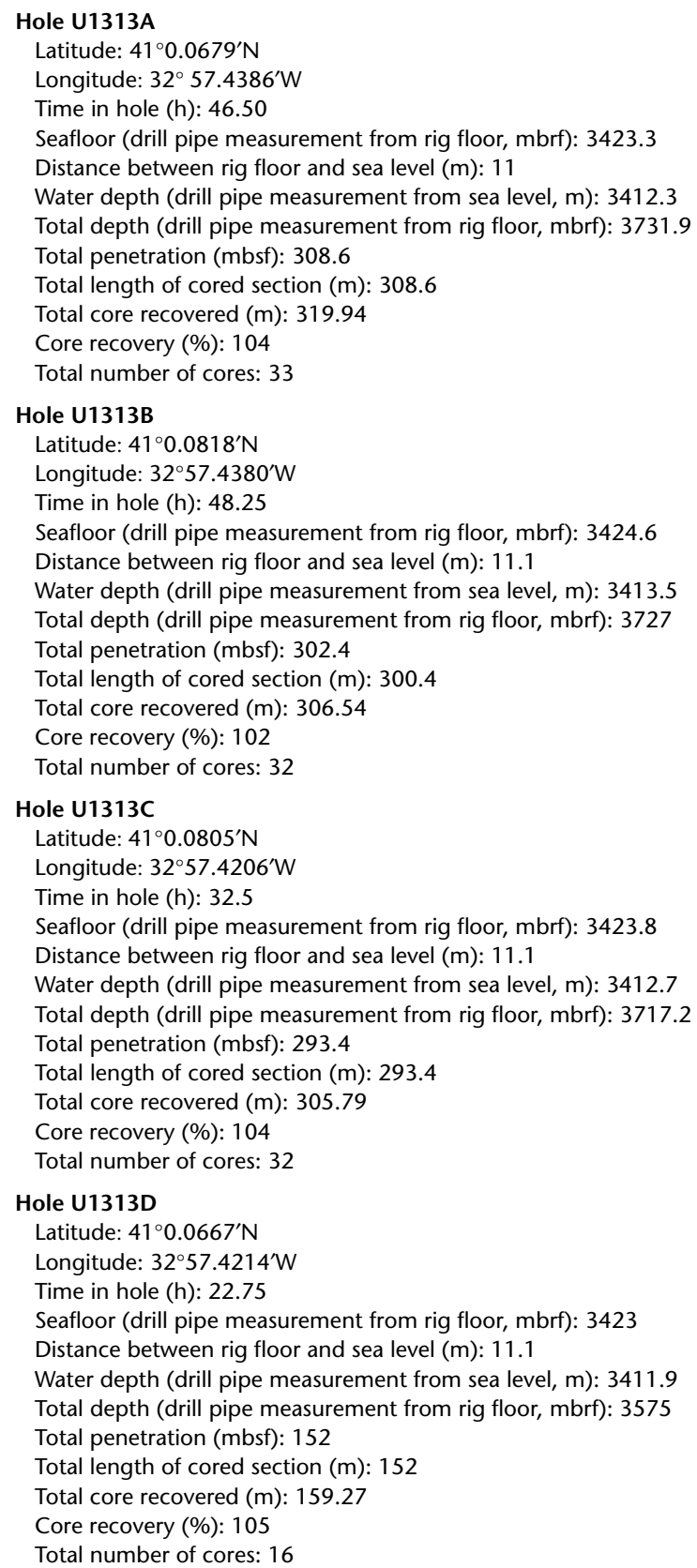

\begin{tabular}{|c|c|c|c|c|c|c|}
\hline & Date & Local & Depth (mbsf) & Length (m) & Recovery & \\
\hline Core & $(2005)$ & time $(h)$ & Top $\quad$ Bottom & Cored Recovered & $(\%)$ & Comments \\
\hline
\end{tabular}
306-U1313A-

\begin{tabular}{|c|c|c|c|c|c|c|c|c|}
\hline $1 \mathrm{H}$ & 28 Mar & 0030 & 0.0 & 5.2 & 5.2 & 5.2 & 99.0 & \\
\hline $2 \mathrm{H}$ & $28 \mathrm{Mar}$ & 0235 & 5.2 & 14.7 & 9.5 & 9.8 & 103.5 & \\
\hline $3 \mathrm{H}$ & $28 \mathrm{Mar}$ & 0335 & 14.7 & 24.2 & 9.5 & 10.1 & 106.0 & Oriented, nonmagnetic core barrel \\
\hline $4 \mathrm{H}$ & $28 \mathrm{Mar}$ & 0430 & 24.2 & 33.7 & 9.5 & 10.0 & 105.3 & Oriented, nonmagnetic core barrel \\
\hline $5 \mathrm{H}$ & $28 \mathrm{Mar}$ & 0520 & 33.7 & 43.2 & 9.5 & 10.1 & 106.6 & Oriented, nonmagnetic core barrel \\
\hline $6 \mathrm{H}$ & $28 \mathrm{Mar}$ & 0620 & 43.2 & 52.7 & 9.5 & 9.7 & 101.7 & Oriented, nonmagnetic core barrel \\
\hline $7 \mathrm{H}$ & $28 \mathrm{Mar}$ & 0715 & 52.7 & 62.2 & 9.5 & 9.9 & 104.3 & Oriented, nonmagnetic core barrel \\
\hline $8 \mathrm{H}$ & $28 \mathrm{Mar}$ & 0805 & 62.2 & 71.7 & 9.5 & 10.1 & 106.4 & Oriented, nonmagnetic core barrel \\
\hline $9 \mathrm{H}$ & $28 \mathrm{Mar}$ & 0855 & 71.7 & 81.2 & 9.5 & 10.1 & 105.9 & Oriented, nonmagnetic core barrel \\
\hline $10 \mathrm{H}$ & $28 \mathrm{Mar}$ & 0950 & 81.2 & 90.7 & 9.5 & 10.0 & 105.1 & Oriented, nonmagnetic core barrel \\
\hline $11 \mathrm{H}$ & $28 \mathrm{Mar}$ & 1045 & 90.7 & 100.2 & 9.5 & 10.0 & 105.5 & Oriented, nonmagnetic core barrel \\
\hline $12 \mathrm{H}$ & $28 \mathrm{Mar}$ & 1145 & 100.2 & 109.7 & 9.5 & 10.0 & 105.2 & Oriented, nonmagnetic core barrel \\
\hline $13 \mathrm{H}$ & $28 \mathrm{Mar}$ & 1240 & 109.7 & 119.2 & 9.5 & 9.9 & 104.2 & Oriented, nonmagnetic core barrel \\
\hline
\end{tabular}


Table T1 (continued).

\begin{tabular}{|c|c|c|c|c|c|c|c|c|}
\hline \multirow[b]{2}{*}{ Core } & \multirow{2}{*}{$\begin{array}{l}\text { Date } \\
(2005)\end{array}$} & \multirow{2}{*}{$\begin{array}{c}\text { Local } \\
\text { time }(\mathrm{h})\end{array}$} & \multicolumn{2}{|c|}{ Depth (mbsf) } & \multicolumn{2}{|c|}{ Length $(\mathrm{m})$} & \multirow{2}{*}{$\begin{array}{l}\text { Recovery } \\
(\%)\end{array}$} & \multirow[b]{2}{*}{ Comments } \\
\hline & & & Top & Bottom & Cored & Recovered & & \\
\hline $14 \mathrm{H}$ & $28 \mathrm{Mar}$ & 1325 & 119.2 & 128.7 & 9.5 & 10.1 & 106.5 & Oriented, nonmagnetic core barrel \\
\hline $15 \mathrm{H}$ & $28 \mathrm{Mar}$ & 1415 & 128.7 & 138.2 & 9.5 & 10.0 & 105.4 & Oriented, nonmagnetic core barrel \\
\hline $16 \mathrm{H}$ & $28 \mathrm{Mar}$ & 1500 & 138.2 & 147.7 & 9.5 & 9.9 & 103.8 & Oriented, nonmagnetic core barrel \\
\hline $17 \mathrm{H}$ & $28 \mathrm{Mar}$ & 1550 & 147.7 & 157.2 & 9.5 & 10.1 & 105.9 & Oriented, nonmagnetic core barrel \\
\hline $18 \mathrm{H}$ & $28 \mathrm{Mar}$ & 1645 & 157.2 & 166.7 & 9.5 & 10.0 & 105.3 & Oriented, nonmagnetic core barrel \\
\hline $19 \mathrm{H}$ & $28 \mathrm{Mar}$ & 1730 & 166.7 & 176.2 & 9.5 & 10.0 & 105.5 & Oriented, nonmagnetic core barrel \\
\hline $20 \mathrm{H}$ & $28 \mathrm{Mar}$ & 1825 & 176.2 & 185.7 & 9.5 & 10.2 & 107.6 & Oriented, nonmagnetic core barrel \\
\hline $21 \mathrm{H}$ & $28 \mathrm{Mar}$ & 1920 & 185.7 & 195.2 & 9.5 & 10.0 & 105.6 & Oriented, nonmagnetic core barrel \\
\hline $22 \mathrm{H}$ & $28 \mathrm{Mar}$ & 2010 & 195.2 & 204.7 & 9.5 & 9.1 & 96.2 & Oriented, nonmagnetic core barrel, liner split open \\
\hline $23 \mathrm{H}$ & $28 \mathrm{Mar}$ & 2100 & 204.7 & 214.2 & 9.5 & 9.2 & 96.4 & Oriented, nonmagnetic core barrel, piston seals stuck in liner \\
\hline $24 \mathrm{H}$ & $28 \mathrm{Mar}$ & 2355 & 214.2 & 223.7 & 9.5 & 10.1 & 105.8 & Oriented, nonmagnetic core barrel \\
\hline $25 \mathrm{H}$ & $29 \mathrm{Mar}$ & 0045 & 223.7 & 233.2 & 9.5 & 10.0 & 104.7 & Oriented, nonmagnetic core barrel \\
\hline $26 \mathrm{H}$ & 29 Mar & 0155 & 233.2 & 242.7 & 9.5 & 10.3 & 108.1 & Oriented, nonmagnetic core barrel, liner imploded \\
\hline $27 \mathrm{H}$ & $29 \mathrm{Mar}$ & 0255 & 242.7 & 252.2 & 9.5 & 9.6 & 100.8 & Oriented, nonmagnetic core barrel \\
\hline $28 \mathrm{H}$ & $29 \mathrm{Mar}$ & 0355 & 252.2 & 261.7 & 9.5 & 9.7 & 101.8 & Oriented, nonmagnetic core barrel \\
\hline $29 \mathrm{H}$ & 29 Mar & 0450 & 261.7 & 271.2 & 9.5 & 9.4 & 98.7 & Oriented, nonmagnetic core barrel \\
\hline $30 \mathrm{H}$ & $29 \mathrm{Mar}$ & 0550 & 271.2 & 280.7 & 9.5 & 9.6 & 100.8 & Oriented, nonmagnetic core barrel \\
\hline $31 \mathrm{H}$ & 29 Mar & 0655 & 280.7 & 290.2 & 9.5 & 9.8 & 103.3 & Oriented, nonmagnetic core barrel \\
\hline $32 \mathrm{H}$ & $29 \mathrm{Mar}$ & 0830 & 290.2 & 299.7 & 9.5 & 9.0 & 94.5 & Drillover \\
\hline \multirow[t]{2}{*}{$33 \mathrm{H}$} & 29 Mar & 1045 & 299.7 & 308.6 & 8.9 & 8.9 & 100.4 & Drillover, Tensor in @ 0820 h \\
\hline & & & \multicolumn{2}{|c|}{ Cored totals: } & 308.60 & 319.64 & 103.58 & \\
\hline
\end{tabular}

306-U1313B-

\begin{tabular}{|c|c|c|c|c|c|c|c|c|}
\hline $1 \mathrm{H}$ & $29 \mathrm{Mar}$ & 1450 & 0.0 & 5.9 & 5.9 & 5.9 & 100.0 & \\
\hline $2 \mathrm{H}$ & $29 \mathrm{Mar}$ & 1545 & 5.9 & 15.4 & 9.5 & 9.9 & 104.5 & \\
\hline $3 \mathrm{H}$ & 29 Mar & 1645 & 15.4 & 24.9 & 9.5 & 9.6 & 101.5 & Oriented, nonmagnetic core barrel \\
\hline $4 \mathrm{H}$ & $29 \mathrm{Mar}$ & 1820 & 24.9 & 34.4 & 9.5 & 9.9 & 104.1 & Oriented, nonmagnetic core barrel \\
\hline $5 \mathrm{H}$ & $29 \mathrm{Mar}$ & 1915 & 34.4 & 43.9 & 9.5 & 9.8 & 102.9 & Oriented, nonmagnetic core barrel \\
\hline $6 \mathrm{H}$ & 29 Mar & 2005 & 43.9 & 53.4 & 9.5 & 10.1 & 106.0 & Oriented, nonmagnetic core barrel \\
\hline $7 \mathrm{H}$ & 29 Mar & 2055 & 53.4 & 62.9 & 9.5 & 9.7 & 102.3 & Oriented, nonmagnetic core barrel \\
\hline $8 \mathrm{H}$ & $29 \mathrm{Mar}$ & 2140 & 62.9 & 72.4 & 9.5 & 10.1 & 106.0 & Oriented, nonmagnetic core barrel \\
\hline $9 \mathrm{H}$ & 29 Mar & 2235 & 72.4 & 81.9 & 9.5 & 9.9 & 104.6 & Oriented, nonmagnetic core barrel \\
\hline $10 \mathrm{H}$ & 29 Mar & 2325 & 81.9 & 91.4 & 9.5 & 9.8 & 103.4 & Oriented, nonmagnetic core barrel \\
\hline $11 \mathrm{H}$ & 30 Mar & 0020 & 91.4 & 100.9 & 9.5 & 10.0 & 105.5 & Oriented, nonmagnetic core barrel \\
\hline $12 \mathrm{H}$ & $30 \mathrm{Mar}$ & 0110 & 100.9 & 110.4 & 9.5 & 10.0 & 104.8 & Oriented, nonmagnetic core barrel \\
\hline $13 \mathrm{H}$ & $30 \mathrm{Mar}$ & 0155 & 110.4 & 119.9 & 9.5 & 10.0 & 105.2 & Oriented, nonmagnetic core barrel \\
\hline $14 \mathrm{H}$ & $30 \mathrm{Mar}$ & 0245 & 119.9 & 129.4 & 9.5 & 10.0 & 105.7 & Oriented, nonmagnetic core barrel \\
\hline $15 \mathrm{H}$ & $30 \mathrm{Mar}$ & 0345 & 129.4 & 138.9 & 9.5 & 10.1 & 105.9 & Oriented, nonmagnetic core barrel \\
\hline $16 \mathrm{H}$ & $30 \mathrm{Mar}$ & 0430 & 138.9 & 148.4 & 9.5 & 10.1 & 105.8 & Oriented, nonmagnetic core barrel \\
\hline $17 \mathrm{H}$ & $30 \mathrm{Mar}$ & 0530 & 148.4 & 157.9 & 9.5 & 10.1 & 106.1 & Oriented, nonmagnetic core barrel \\
\hline $18 \mathrm{H}$ & $30 \mathrm{Mar}$ & 0625 & 157.9 & 167.4 & 9.5 & 9.9 & 104.6 & Oriented, nonmagnetic core barrel \\
\hline $19 \mathrm{H}$ & $30 \mathrm{Mar}$ & 0715 & 167.4 & 176.9 & 9.5 & 10.1 & 105.8 & Oriented, nonmagnetic core barrel \\
\hline $20 \mathrm{H}$ & $30 \mathrm{Mar}$ & 0805 & 176.9 & 186.4 & 9.5 & 9.8 & 103.1 & Oriented, nonmagnetic core barrel \\
\hline 210 & 30 Mar & 0825 & \multicolumn{6}{|c|}{ 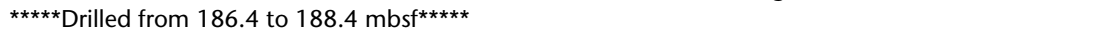 } \\
\hline $21 \mathrm{H}$ & $30 \mathrm{Mar}$ & 0855 & 188.4 & 197.9 & 9.5 & 9.6 & 100.5 & Oriented, nonmagnetic core barrel \\
\hline $22 \mathrm{H}$ & 30 Mar & 0955 & 197.9 & 207.4 & 9.5 & 10.0 & 105.4 & Oriented, nonmagnetic core barrel \\
\hline $23 \mathrm{H}$ & $30 \mathrm{Mar}$ & 1045 & 207.4 & 216.9 & 9.5 & 10.0 & 104.7 & Oriented, nonmagnetic core barrel \\
\hline $24 \mathrm{H}$ & $30 \mathrm{Mar}$ & 1145 & 216.9 & 226.4 & 9.5 & 8.4 & 87.9 & Oriented, nonmagnetic core barrel, broken liner \\
\hline $25 \mathrm{H}$ & $30 \mathrm{Mar}$ & 1235 & 226.4 & 235.9 & 9.5 & 8.9 & 93.9 & Oriented, nonmagnetic core barrel, broken liner \\
\hline $26 \mathrm{H}$ & $30 \mathrm{Mar}$ & 1340 & 235.9 & 245.4 & 9.5 & 8.1 & 85.2 & Oriented, nonmagnetic core barrel, broken liner \\
\hline $27 \mathrm{H}$ & $30 \mathrm{Mar}$ & 1440 & 245.4 & 254.9 & 9.5 & 9.8 & 103.3 & Oriented, nonmagnetic core barrel \\
\hline $28 \mathrm{H}$ & $30 \mathrm{Mar}$ & 1540 & 254.9 & 264.4 & 9.5 & 9.6 & 100.5 & Oriented, nonmagnetic core barrel \\
\hline $29 \mathrm{H}$ & $30 \mathrm{Mar}$ & 1630 & 264.4 & 273.9 & 9.5 & 9.6 & 100.9 & Oriented, nonmagnetic core barrel \\
\hline $30 \mathrm{H}$ & $30 \mathrm{Mar}$ & 1720 & 273.9 & 283.4 & 9.5 & 8.4 & 88.4 & Oriented, nonmagnetic core barrel \\
\hline $31 \mathrm{H}$ & 30 Mar & 1820 & 283.4 & 292.9 & 9.5 & 9.8 & 103.3 & Oriented, nonmagnetic core barrel \\
\hline $32 \mathrm{H}$ & 30 Mar & 1925 & 292.9 & 302.4 & 9.5 & 9.8 & 102.8 & Oriented, nonmagnetic core barrel \\
\hline
\end{tabular}

\begin{tabular}{|c|c|c|c|c|c|c|c|c|}
\hline & & & & & \multicolumn{4}{|c|}{ 06-U1313C- } \\
\hline $1 \mathrm{H}$ & 31 Mar & 1500 & 0.0 & 2.7 & 2.7 & 2.7 & 100.4 & \\
\hline $2 \mathrm{H}$ & 31 Mar & 1545 & 2.7 & 12.2 & 9.5 & 10.0 & 105.7 & \\
\hline $3 \mathrm{H}$ & 31 Mar & 1625 & 12.2 & 21.7 & 9.5 & 10.0 & 105.7 & \\
\hline $4 \mathrm{H}$ & 31 Mar & 1720 & 21.7 & 31.2 & 9.5 & 10.1 & 105.9 & Oriented, nonmagnetic core barrel \\
\hline $5 \mathrm{H}$ & 31 Mar & 1805 & 31.2 & 40.7 & 9.5 & 10.1 & 106.0 & Oriented, nonmagnetic core barrel \\
\hline $6 \mathrm{H}$ & 31 Mar & 1900 & 40.7 & 50.2 & 9.5 & 9.9 & 104.4 & Oriented, nonmagnetic core barrel \\
\hline $7 \mathrm{H}$ & $31 \mathrm{Mar}$ & 1945 & 50.2 & 59.7 & 9.5 & 10.0 & 104.7 & Oriented, nonmagnetic core barrel \\
\hline $8 \mathrm{H}$ & 31 Mar & 2035 & 59.7 & 69.2 & 9.5 & 10.1 & 106.0 & Oriented, nonmagnetic core barrel \\
\hline $9 \mathrm{H}$ & $31 \mathrm{Mar}$ & 2120 & 69.2 & 78.7 & 9.5 & 10.0 & 105.1 & Oriented, nonmagnetic core barrel \\
\hline $10 \mathrm{H}$ & $31 \mathrm{Mar}$ & 2205 & 78.7 & 88.2 & 9.5 & 9.9 & 103.8 & Oriented, nonmagnetic core barrel \\
\hline $11 \mathrm{H}$ & 31 Mar & 2255 & 88.2 & 97.7 & 9.5 & 9.9 & 104.5 & Oriented, nonmagnetic core barrel \\
\hline
\end{tabular}


Table T1 (continued).

\begin{tabular}{|c|c|c|c|c|c|c|c|c|}
\hline \multirow[b]{2}{*}{ Core } & \multirow{2}{*}{$\begin{array}{c}\text { Date } \\
(2005)\end{array}$} & \multirow{2}{*}{$\begin{array}{c}\text { Local } \\
\text { time }(\mathrm{h})\end{array}$} & \multicolumn{2}{|c|}{ Depth (mbsf) } & \multicolumn{2}{|c|}{ Length (m) } & \multirow{2}{*}{$\begin{array}{c}\text { Recovery } \\
(\%)\end{array}$} & \multirow[b]{2}{*}{ Comments } \\
\hline & & & Top & Bottom & Cored & Recovered & & \\
\hline $12 \mathrm{H}$ & 31 Mar & 2340 & 97.7 & 107.2 & 9.5 & 10.0 & 105.3 & Oriented, nonmagnetic core barrel \\
\hline $13 \mathrm{H}$ & $1 \mathrm{Apr}$ & 0030 & 107.2 & 116.7 & 9.5 & 10.0 & 104.7 & Oriented, nonmagnetic core barrel \\
\hline $14 \mathrm{H}$ & $1 \mathrm{Apr}$ & 0115 & 116.7 & 126.2 & 9.5 & 10.0 & 105.6 & Oriented, nonmagnetic core barrel \\
\hline $15 \mathrm{H}$ & $1 \mathrm{Apr}$ & 0205 & 126.2 & 135.7 & 9.5 & 10.0 & 105.7 & Oriented, nonmagnetic core barrel \\
\hline $16 \mathrm{H}$ & $1 \mathrm{Apr}$ & 0250 & 135.7 & 145.2 & 9.5 & 9.8 & 102.8 & Oriented, nonmagnetic core barrel, liner problems @ piston \\
\hline $17 \mathrm{H}$ & $1 \mathrm{Apr}$ & 0440 & 145.2 & 154.7 & 9.5 & 10.0 & 105.3 & Oriented, nonmagnetic core barrel, changed all seals on core barrel \\
\hline $18 \mathrm{H}$ & $1 \mathrm{Apr}$ & 0530 & 154.7 & 164.2 & 9.5 & 10.0 & 105.7 & Oriented, nonmagnetic core barrel \\
\hline $19 \mathrm{H}$ & $1 \mathrm{Apr}$ & 0625 & 164.2 & 173.7 & 9.5 & 9.8 & 103.5 & Oriented, nonmagnetic core barrel \\
\hline $20 \mathrm{H}$ & $1 \mathrm{Apr}$ & 0715 & 173.7 & 183.2 & 9.5 & 9.6 & 101.4 & Oriented, nonmagnetic core barrel \\
\hline $21 \mathrm{H}$ & $1 \mathrm{Apr}$ & 0800 & 183.2 & 192.7 & 9.5 & 10.0 & 105.7 & Oriented, nonmagnetic core barrel \\
\hline $22 \mathrm{H}$ & $1 \mathrm{Apr}$ & 0850 & 192.7 & 202.2 & 9.5 & 10.1 & 105.8 & Oriented, nonmagnetic core barrel \\
\hline $23 \mathrm{H}$ & $1 \mathrm{Apr}$ & 0945 & 202.2 & 211.7 & 9.5 & 10.1 & 106.4 & Oriented, nonmagnetic core barrel \\
\hline $24 \mathrm{H}$ & $1 \mathrm{Apr}$ & 1030 & 211.7 & 221.2 & 9.5 & 9.8 & 103.6 & Oriented, nonmagnetic core barrel \\
\hline $25 \mathrm{H}$ & $1 \mathrm{Apr}$ & 1115 & 221.2 & 230.7 & 9.5 & 9.7 & 102.4 & Oriented, nonmagnetic core barrel \\
\hline $26 \mathrm{H}$ & $1 \mathrm{Apr}$ & 1210 & 230.7 & 240.2 & 9.5 & 9.7 & 101.9 & Oriented, nonmagnetic core barrel \\
\hline $27 \mathrm{H}$ & $1 \mathrm{Apr}$ & 1305 & 240.2 & 249.7 & 9.5 & 9.6 & 100.9 & Oriented, nonmagnetic core barrel \\
\hline $28 \mathrm{H}$ & $1 \mathrm{Apr}$ & 1355 & 249.7 & 259.2 & 9.5 & 9.7 & 101.7 & Oriented, nonmagnetic core barrel \\
\hline $29 \mathrm{H}$ & $1 \mathrm{Apr}$ & 1540 & 259.2 & 268.7 & 9.5 & 9.8 & 103.1 & Drillover \\
\hline $30 \mathrm{H}$ & $1 \mathrm{Apr}$ & 1705 & 268.7 & 278.2 & 9.5 & 10.1 & 106.3 & Drillover \\
\hline $31 \mathrm{H}$ & $1 \mathrm{Apr}$ & 1830 & 278.2 & 286.9 & 8.7 & 8.7 & 100.3 & Drillover \\
\hline \multirow[t]{2}{*}{$32 \mathrm{H}$} & $1 \mathrm{Apr}$ & 1940 & 286.9 & 293.4 & 6.5 & 6.6 & 100.8 & Drillover \\
\hline & & & \multicolumn{2}{|c|}{ Cored totals: } & 293.40 & 305.79 & 104.22 & \\
\hline \multicolumn{9}{|c|}{ 306-U1313D- } \\
\hline $1 \mathrm{H}$ & $1 \mathrm{Apr}$ & 2315 & 0.0 & 9.5 & 9.5 & 9.8 & 103.2 & \\
\hline $2 \mathrm{H}$ & $2 \mathrm{Apr}$ & 0005 & 9.5 & 19.0 & 9.5 & 9.8 & 103.6 & \\
\hline $3 \mathrm{H}$ & $2 \mathrm{Apr}$ & 0055 & 19.0 & 28.5 & 9.5 & 9.8 & 102.9 & Oriented, nonmagnetic core barrel \\
\hline $4 \mathrm{H}$ & $2 \mathrm{Apr}$ & 0140 & 28.5 & 38.0 & 9.5 & 9.8 & 103.1 & Oriented, nonmagnetic core barrel \\
\hline $5 \mathrm{H}$ & $2 \mathrm{Apr}$ & 0230 & 38.0 & 47.5 & 9.5 & 9.8 & 103.1 & Oriented, nonmagnetic core barrel \\
\hline $6 \mathrm{H}$ & $2 \mathrm{Apr}$ & 0320 & 47.5 & 57.0 & 9.5 & 10.1 & 106.3 & Oriented, nonmagnetic core barrel \\
\hline $7 \mathrm{H}$ & $2 \mathrm{Apr}$ & 0405 & 57.0 & 66.5 & 9.5 & 10.0 & 105.3 & Oriented, nonmagnetic core barrel \\
\hline $8 \mathrm{H}$ & $2 \mathrm{Apr}$ & 0450 & 66.5 & 76.0 & 9.5 & 10.0 & 104.9 & Oriented, nonmagnetic core barrel \\
\hline $9 \mathrm{H}$ & $2 \mathrm{Apr}$ & 0540 & 76.0 & 85.5 & 9.5 & 10.0 & 105.1 & Oriented, nonmagnetic core barrel \\
\hline $10 \mathrm{H}$ & $2 \mathrm{Apr}$ & 0630 & 85.5 & 95.0 & 9.5 & 10.0 & 104.9 & Oriented, nonmagnetic core barrel \\
\hline $11 \mathrm{H}$ & $2 \mathrm{Apr}$ & 0715 & 95.0 & 104.5 & 9.5 & 10.1 & 106.4 & Oriented, nonmagnetic core barrel \\
\hline $12 \mathrm{H}$ & $2 \mathrm{Apr}$ & 0810 & 104.5 & 114.0 & 9.5 & 10.1 & 106.4 & Oriented, nonmagnetic core barrel \\
\hline $13 \mathrm{H}$ & $2 \mathrm{Apr}$ & 0900 & 114.0 & 123.5 & 9.5 & 10.0 & 104.7 & Oriented, nonmagnetic core barrel \\
\hline $14 \mathrm{H}$ & $2 \mathrm{Apr}$ & 0950 & 123.5 & 133.0 & 9.5 & 10.1 & 106.4 & Oriented, nonmagnetic core barrel \\
\hline $15 \mathrm{H}$ & $2 \mathrm{Apr}$ & 1035 & 133.0 & 142.5 & 9.5 & 10.1 & 106.6 & Oriented, nonmagnetic core barrel \\
\hline \multirow[t]{2}{*}{$16 \mathrm{H}$} & $2 \mathrm{Apr}$ & 1145 & 142.5 & 152.0 & 9.5 & 9.8 & 103.6 & Oriented, nonmagnetic core barrel \\
\hline & & & \multicolumn{2}{|c|}{ Cored totals: } & 152.00 & 159.27 & 104.78 & \\
\hline
\end{tabular}


Table T2. Isolated gravel data, lithology, diameter, and shape, Holes U1313A, U1312B, U1313C, and U1313D.

\begin{tabular}{|c|c|c|}
\hline $\begin{array}{l}\text { Core, section, } \\
\text { interval }(\mathrm{cm})\end{array}$ & $\begin{array}{l}\text { Depth } \\
\text { (mbsf) }\end{array}$ & Comments \\
\hline \multicolumn{3}{|l|}{ 306-U1313A- } \\
\hline $1 \mathrm{H}-1,44$ & 0.44 & Unidentified clast \\
\hline $4 \mathrm{H}-1,115$ & 25.35 & Carbonate clast, subangular \\
\hline $4 \mathrm{H}-1,124-129$ & $25.44-25.49$ & Carbonate clasts $(\times 4)$, subangular \\
\hline $4 \mathrm{H}-6,14$ & 31.84 & Carbonate clast, subangular \\
\hline $6 \mathrm{H}-7,77-81$ & $51.65-51.69$ & Carbonate clasts $(\times 2), \mathrm{d}=3 \mathrm{~mm}, 8 \mathrm{~mm}$, subrounded \\
\hline $7 \mathrm{H}-4,57$ & 57.77 & Carbonate clast, $d=15 \mathrm{~mm}$, subangular \\
\hline $7 \mathrm{H}-6,82$ & 61.02 & Carbonate clast, $\mathrm{d}=8 \mathrm{~mm}$, subrounded \\
\hline $8 \mathrm{H}-5,101$ & 69.21 & Igneous clast, felsic, $\mathrm{d}=5 \mathrm{~mm}$ \\
\hline $10 \mathrm{H}-5,114-120$ & $88.34-88.4$ & Unidentified clast, $\mathrm{d}=3 \mathrm{~mm}$; igneous clasts, mafic $(\times 7), \mathrm{d}=4-22 \mathrm{~mm}$ \\
\hline $12 \mathrm{H}-5,125$ & 107.45 & Unidentified clast, broken into several fragments \\
\hline $14 \mathrm{H}-5,146$ & 126.66 & Carbonate clast, $\mathrm{d}=6 \mathrm{~mm}$ \\
\hline $18 \mathrm{H}-1,7$ & 157.27 & Carbonate clast (?), subrounded, in flow-/fall-in \\
\hline $20 \mathrm{H}-1,12$ & 176.32 & Igneous clast, mafic, $\mathrm{d}=30 \mathrm{~mm}$, subrounded \\
\hline \multicolumn{3}{|l|}{ 306-U1313B- } \\
\hline $4 \mathrm{H}-1,89$ & 25.79 & Unidentified clast, $\mathrm{d}=30 \mathrm{~mm}$, subrounded \\
\hline $5 \mathrm{H}-6,108$ & 42.98 & Unidentified clast, $\mathrm{d}=23 \mathrm{~mm}$ \\
\hline $7 \mathrm{H}-2,62-72$ & $55.52-55.62$ & Unidentified clast, $\mathrm{d}=5 \mathrm{~mm}$, subrounded \\
\hline 7H-3, 115-149 & $57.55-57.89$ & Volcanic clast, $\mathrm{d}=13 \mathrm{~mm}$, subrounded \\
\hline & & Carbonate clasts $(\times 4), d=2-10 \mathrm{~mm}$, subangular \\
\hline $8 \mathrm{H}-1,121-141$ & $64.11-64.31$ & Unidentified clasts $(\times 5), d=2-6 \mathrm{~mm}$, subrounded to subangular \\
\hline $8 \mathrm{H}-4,81-93$ & $68.21-68.33$ & Carbonate clasts $(\times 3), \mathrm{d}=2-3 \mathrm{~mm}$, subrounded to subangular \\
\hline $8 \mathrm{H}-5,11-19$ & $69.01-69.09$ & Carbonate clasts $(\times 3), \mathrm{d}=3-5 \mathrm{~mm}$, subangular \\
\hline $9 \mathrm{H}-1,1$ & 72.41 & Unidentified clast, $\mathrm{d}=10 \mathrm{~mm}$, in fall-in? \\
\hline $10 \mathrm{H}-4,121-144$ & $87.61-87.84$ & Carbonate clasts $(\times 4), \mathrm{d}=3-8 \mathrm{~mm}$, angular; Basalt (?) clast, $\mathrm{d}=7 \mathrm{~mm}$, angular \\
\hline $11 \mathrm{H}-1,118$ & 92.58 & Carbonate clast, $\mathrm{d}=4 \mathrm{~mm}$, subrounded \\
\hline $12 \mathrm{H}-6,1-14$ & $108.41-108.54$ & Carbonate clasts $(\times 4), \mathrm{d}=2-6 \mathrm{~mm}$, angular \\
\hline \multicolumn{3}{|l|}{ 306-U1313C- } \\
\hline $4 \mathrm{H}-2,97$ & 24.17 & Carbonate (?) clast, $\mathrm{d}=4 \mathrm{~mm}$, subrounded \\
\hline $4 \mathrm{H}-3,117$ & 25.87 & Carbonate clast, $\mathrm{d}=6 \mathrm{~mm}$, rounded, broken \\
\hline $4 \mathrm{H}-4,79$ & 26.99 & Carbonate clast, $\mathrm{d}=7 \mathrm{~mm}$, subangular \\
\hline 7H-1, 113-134 & $51.33-51.54$ & Carbonate/claystone clasts $(\times 16), \mathrm{d}=2-4 \mathrm{~mm}$, rounded to angular \\
\hline 7H-6, 124-140 & $58.94-59.07$ & Carbonate clasts $(\times 11), \mathrm{d}=3-7 \mathrm{~mm}$, subangular \\
\hline $8 \mathrm{H}-4,128-131$ & $65.48-65.51$ & Carbonate clasts $(\times 5), \mathrm{d}=3-4 \mathrm{~mm}$, subangular \\
\hline $9 \mathrm{H}-1,53-111$ & $69.73-70.31$ & $\begin{array}{l}\text { Sandstone clasts }(\times 2), d=2-6 \mathrm{~mm} \text {, subangular to subrounded; Schist clast, } d=6 \mathrm{~mm} \text {, subangular; Unidentified } \\
\text { clast, } d=2 \mathrm{~mm} \text {, angular }\end{array}$ \\
\hline $13 \mathrm{H}-2,26$ & 108.96 & Unidentified clast, $\mathrm{d}=30 \mathrm{~mm}$ \\
\hline \multicolumn{3}{|l|}{ 306-U1313D- } \\
\hline $1 \mathrm{H}-1,148$ & 0.148 & Unidentified clast, silicate (?), d = $10 \mathrm{~mm}$, subrounded \\
\hline $7 \mathrm{H}-1,67-87$ & $57.67-57.84$ & Volcanic clasts $(\times 16), d=m m-s c a l e$, subangular \\
\hline 7H-CC, 15 & 66.88 & Unidentified clast, felsic, $\mathrm{d}=3 \mathrm{~mm}$ \\
\hline $8 \mathrm{H}-7,3$ & 75.53 & Igneous clast, $\mathrm{d}=5 \mathrm{~mm}$ \\
\hline $9 \mathrm{H}-1,37$ & 76.37 & Unidentified clast, $\mathrm{d}=5 \mathrm{~mm}$, subrounded \\
\hline $10 \mathrm{H}-3,35-55$ & $88.85-89.05$ & Unidentified clasts $(\times 12), d=m m-s c a l e$, subangular \\
\hline
\end{tabular}

Note: $\mathrm{d}=$ diameter. 
Table T3. Occurrence of event and ash beds, Holes U1313A, U1313B, U1313C, and U1313D.

\begin{tabular}{|c|c|c|c|}
\hline \multirow{2}{*}{$\begin{array}{l}\text { Core, section, } \\
\text { interval }(\mathrm{cm})\end{array}$} & \multicolumn{2}{|c|}{ Depth (mbsf) } & \multirow[b]{2}{*}{ Comments } \\
\hline & Top & Bottom & \\
\hline \multicolumn{4}{|l|}{ 306-U1313A- } \\
\hline $4 \mathrm{H}-6,127-132$ & 32.97 & 33.02 & Volcanic ash, sharp, erosional base and gradational upper contact \\
\hline $8 \mathrm{H}-4,123$ & 67.93 & & Volcanic ash, millimeter scale \\
\hline $12 \mathrm{H}-1,42-71$ & 100.62 & 100.91 & Sharp lower and upper contact \\
\hline $16 \mathrm{H}-5,97-100$ & 145.17 & 145.2 & Sharp, erosive base \\
\hline $17 \mathrm{H}-1,47-49$ & 148.17 & 148.19 & Sharp, erosive base, pyrite \\
\hline $19 \mathrm{H}-3,34-37$ & 170.04 & 170.07 & Sharp lower contact, normal grading and gradational upper contact \\
\hline $20 \mathrm{H}-1,124-133$ & 177.44 & 177.53 & Sharp lower contact, normal grading and gradational upper contact, pyrite-rich base \\
\hline $29 \mathrm{H}-6,127-132$ & 270.47 & 270.52 & Sharp lower contact, normal grading and inclined, gradational upper contact \\
\hline \multicolumn{4}{|l|}{ 306-U1313B- } \\
\hline $4 \mathrm{H}-6,22-24$ & 32.62 & 32.34 & Volcanic ash \\
\hline $16 \mathrm{H}-4,79-82.5$ & 144.19 & 144.225 & Sharp lower contact, normal grading and gradational upper contact \\
\hline $19 \mathrm{H}-2,41.5-43$ & 169.315 & & Sharp lower contact, normal grading and gradational upper contact, pyrite-rich base \\
\hline $20 \mathrm{H}-1,18-23$ & 177.08 & 177.13 & Sharp and erosional lower contact, normal grading, gradational upper contact, pyrite-rich base \\
\hline $29 \mathrm{H}-5,56-58.5$ & 270.96 & 270.985 & Sharp lower contact, normal grading and gradational upper contact, pyrite-rich base \\
\hline \multicolumn{4}{|l|}{ 306-U1313C- } \\
\hline $2 \mathrm{H}-5,13.5-16$ & 8.835 & 8.86 & Sharp lower contact, normal grading and gradational upper contact, pyrite-rich base \\
\hline $4 \mathrm{H}-1,133-137$ & 23.03 & 23.07 & Sharp lower contact, normal grading and gradational upper contact \\
\hline $5 \mathrm{H}-1,148$ & 32.68 & & Volcanic ash, millimeter-scale \\
\hline $12 \mathrm{H}-3,79-103$ & 101.49 & 101.73 & Sharp lower and upper contact, normal grading \\
\hline $16 \mathrm{H}-7,10.5-14$ & 144.805 & 144.84 & Sharp base, normal grading and gradational upper contact, pyrite-rich base \\
\hline $19 \mathrm{H}-5,27-32$ & 170.47 & 170.52 & Sharp base, normal grading and gradational upper contact, pyrite-rich base \\
\hline $20 \mathrm{H}-3,120-133$ & 177.9 & 178.03 & Sharp base, normal grading and gradational upper contact, pyrite-rich base \\
\hline \multicolumn{4}{|l|}{ 306-U1313D- } \\
\hline $11 \mathrm{H}-6,50-79$ & 103 & 103.29 & Sharp base, normal grading and gradational upper contact, pyrite-rich base \\
\hline
\end{tabular}


Table T4. Calcareous nannofossil, planktonic and benthic foraminifer, and diatom biostratigraphic events, Holes U1313A, U1313B, U1313C, and U1313D.

\begin{tabular}{|c|c|c|c|c|c|}
\hline \multirow[b]{2}{*}{ Species event } & \multirow[b]{2}{*}{$\begin{array}{l}\text { Age } \\
(\mathrm{Ma})\end{array}$} & \multicolumn{4}{|c|}{ Depth (mbsf) } \\
\hline & & $\begin{array}{l}\text { Hole } \\
\text { U1313A }\end{array}$ & $\begin{array}{c}\text { Hole } \\
\text { U1313B }\end{array}$ & $\begin{array}{c}\text { Hole } \\
\text { U1313C }\end{array}$ & $\begin{array}{c}\text { Hole } \\
\text { U1313D }\end{array}$ \\
\hline LO Helicosphaera inversa & 0.16 & & 7.45 & 7.45 & 4.75 \\
\hline FO Emiliania huxleyi & 0.25 & 18.45 & 17.32 & 16.95 & 14.25 \\
\hline LO Pseudoemiliania lacunosa & 0.41 & 18.45 & 17.32 & 16.95 & 23.75 \\
\hline LO Fragilariopsis reinholdii & 0.50 & 28.95 & 29.65 & & 33.25 \\
\hline FO Helicosphaera inversa & 0.51 & 18.45 & 22.07 & 16.95 & 23.75 \\
\hline LO Reticulofenestra asanoi & 0.85 & 22.45 & 26.91 & 26.45 & 33.25 \\
\hline FO Gephyrocapsa parallela & 0.95 & 38.45 & 41.49 & 45.45 & 42.75 \\
\hline LO Stilostomella lepidula & 1.00 & 38.45 & & 45.45 & \\
\hline FO Reticulofenestra asanoi & 1.16 & 47.235 & 46.65 & 45.45 & 52.25 \\
\hline LO large Gephyrocapsa spp. & 1.21 & 47.235 & 51.4 & 45.45 & \\
\hline LO Helicosphaera sellii & 1.27 & 57.45 & 55.95 & 54.95 & 52.25 \\
\hline FO large Gephyrocapsa spp. & 1.45 & 66.95 & 63.2 & 73.95 & \\
\hline FO Gephyrocapsa caribbeanica & 1.73 & 76.45 & 75.465 & 83.45 & 80.75 \\
\hline FaO Neogloboquadrina pachyderma (s) & 1.78 & 76.45 & & & \\
\hline LO Discoaster brouweri & 1.97 & 85.95 & 79.8 & 83.45 & 80.75 \\
\hline FO Globorotalia truncatulinoides & 2.08 & & & 73.95 & 90.25 \\
\hline FO Globorotalia inflata & 2.09 & 95.45 & 96.15 & 83.45 & 99.75 \\
\hline LO Discoaster pentaradiatus & 2.38 & 95.45 & 101.3 & 102.45 & 99.75 \\
\hline LO Globorotalia miocenica & 2.40 & 95.45 & 115.15 & & 109.25 \\
\hline LO Globorotalia puncticulata & 2.41 & 104.95 & 105.65 & 92.95 & 109.25 \\
\hline LO Discoaster surculus & 2.54 & 104.95 & 106.05 & 102.45 & 109.25 \\
\hline LO Discoaster tamalis & 2.74 & 114.45 & 115.15 & 102.45 & 118.75 \\
\hline Disappearance Globorotalia hirsuta & 3.18 & 133.45 & 134.15 & 140.45 & 137.75 \\
\hline LO Sphaeroidinellopsis seminulina & 3.19 & 133.45 & 134.15 & 130.95 & \\
\hline Reappearance Globorotalia puncticulata & 3.31 & 142.95 & 134.15 & 140.45 & \\
\hline Disappearance Globorotalia puncticulata & 3.57 & 152.45 & 143.65 & 149.95 & \\
\hline LO Globorotalia margaritae & 3.81 & 161.95 & 162.65 & 168.95 & \\
\hline LO Reticulofenestra pseudoumbilicus & 3.85 & 152.45 & 153.15 & 159.45 & \\
\hline LcO Globorotalia margaritae & 3.98 & 171.45 & 162.65 & 178.45 & \\
\hline FO Globorotalia puncticulata & 4.52 & 190.45 & 193.15 & 197.45 & \\
\hline FO Globorotalia crassaformis & 4.52 & 190.45 & 193.15 & & \\
\hline LO Globigerina nepenthes & 4.89 & 199.95 & 202.65 & 206.95 & \\
\hline FO Ceratolithus cristatus (rugosus) & 5.089 & 218.95 & & 206.95 & \\
\hline LO Discoaster quinqueramus & 5.537 & 228.45 & 231.15 & 225.95 & \\
\hline LO Amaurolithus amplificus & 5.999 & 294.95 & & 290.15 & \\
\hline
\end{tabular}

Notes: Dark blue $=$ nannofossils, pink = foraminifers, light blue = diatoms. For first occurrences (FO) and first abundant occurrences (FaO), depth is plotted as the midpoint between the depth at which the species was first observed and the depth of the sample below. For last occurrences (LO) and last common occurrences (LCO), depth is plotted as the midpoint between the depth at which the species was last observed and the depth of the sample above. $s=$ sinistral. 


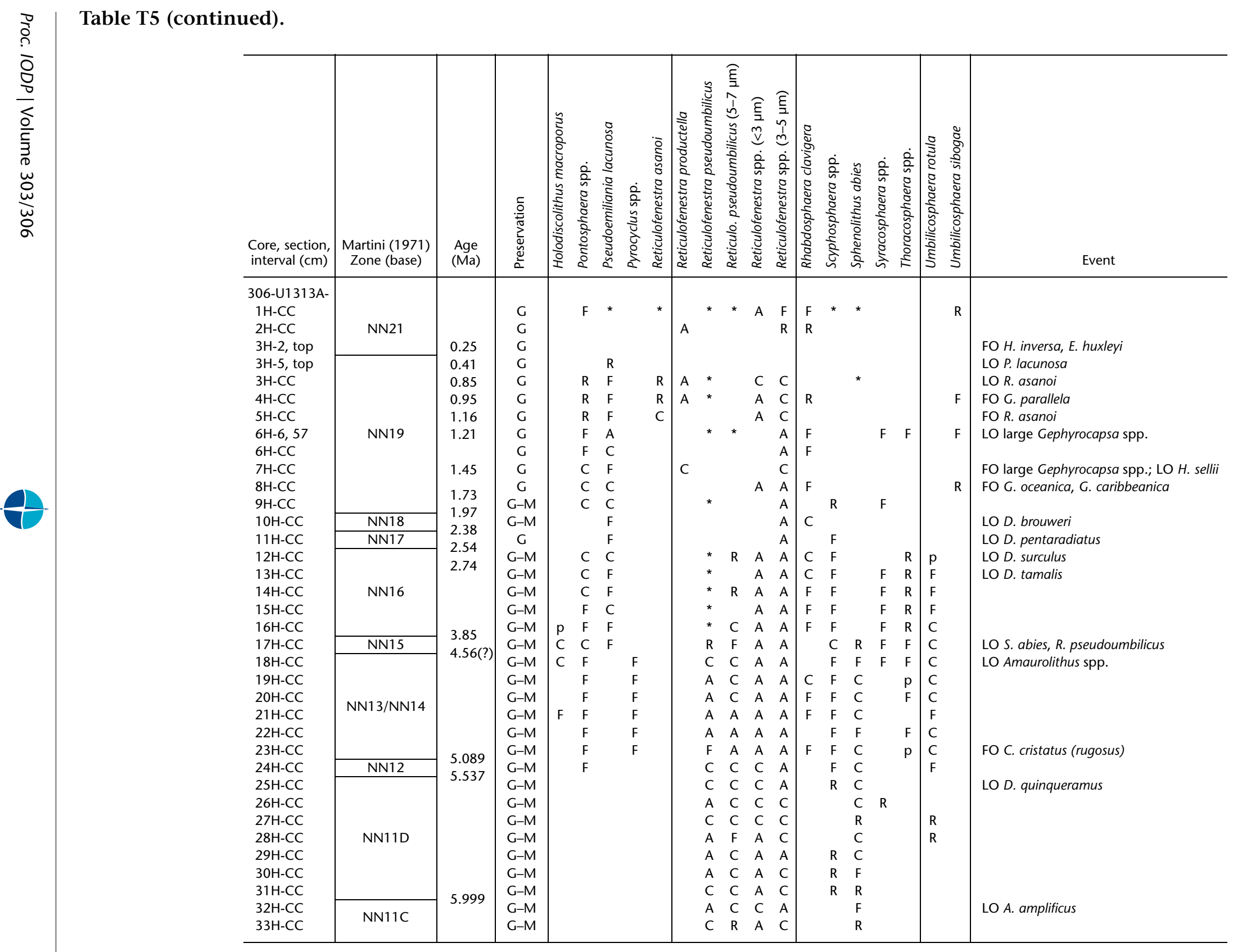




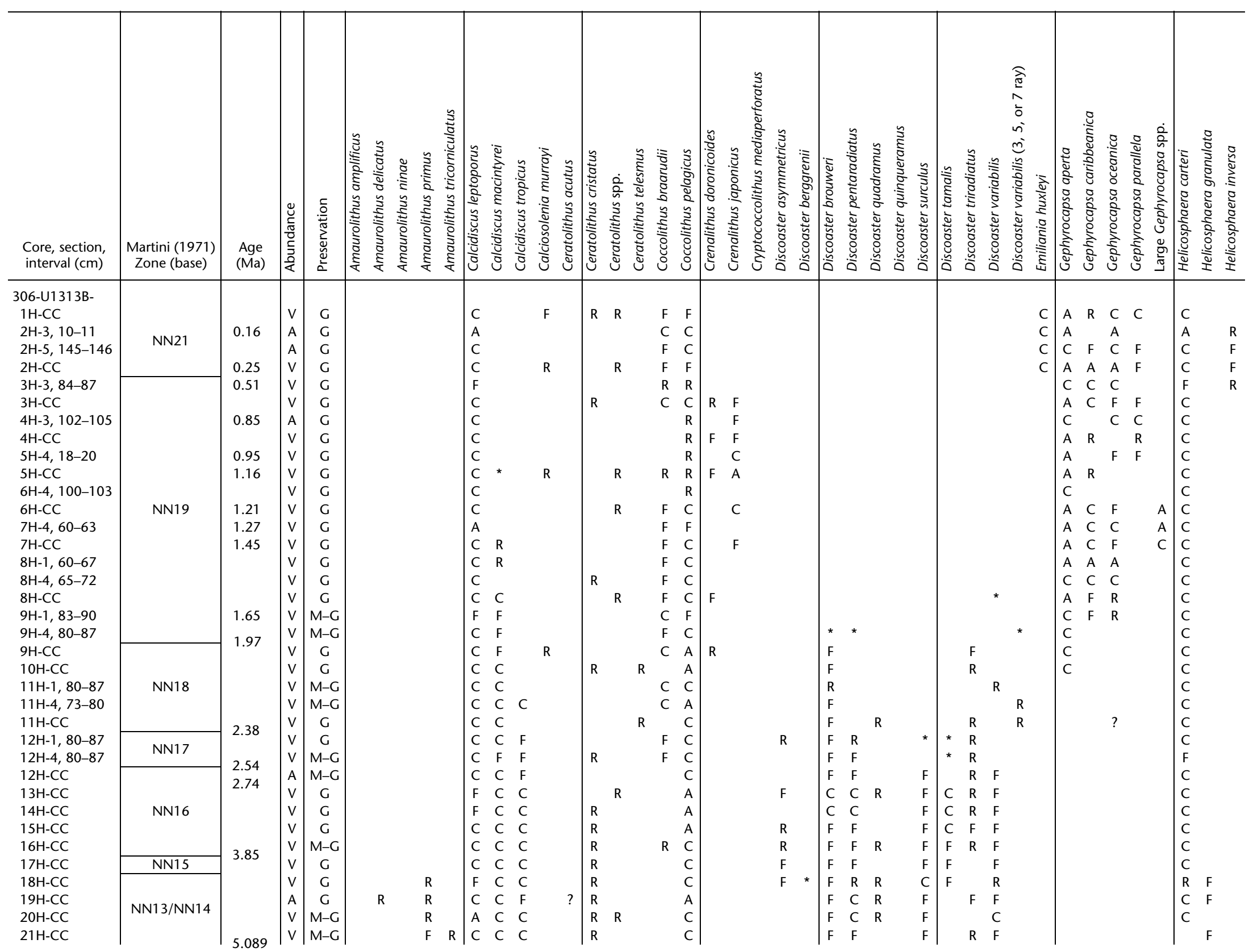



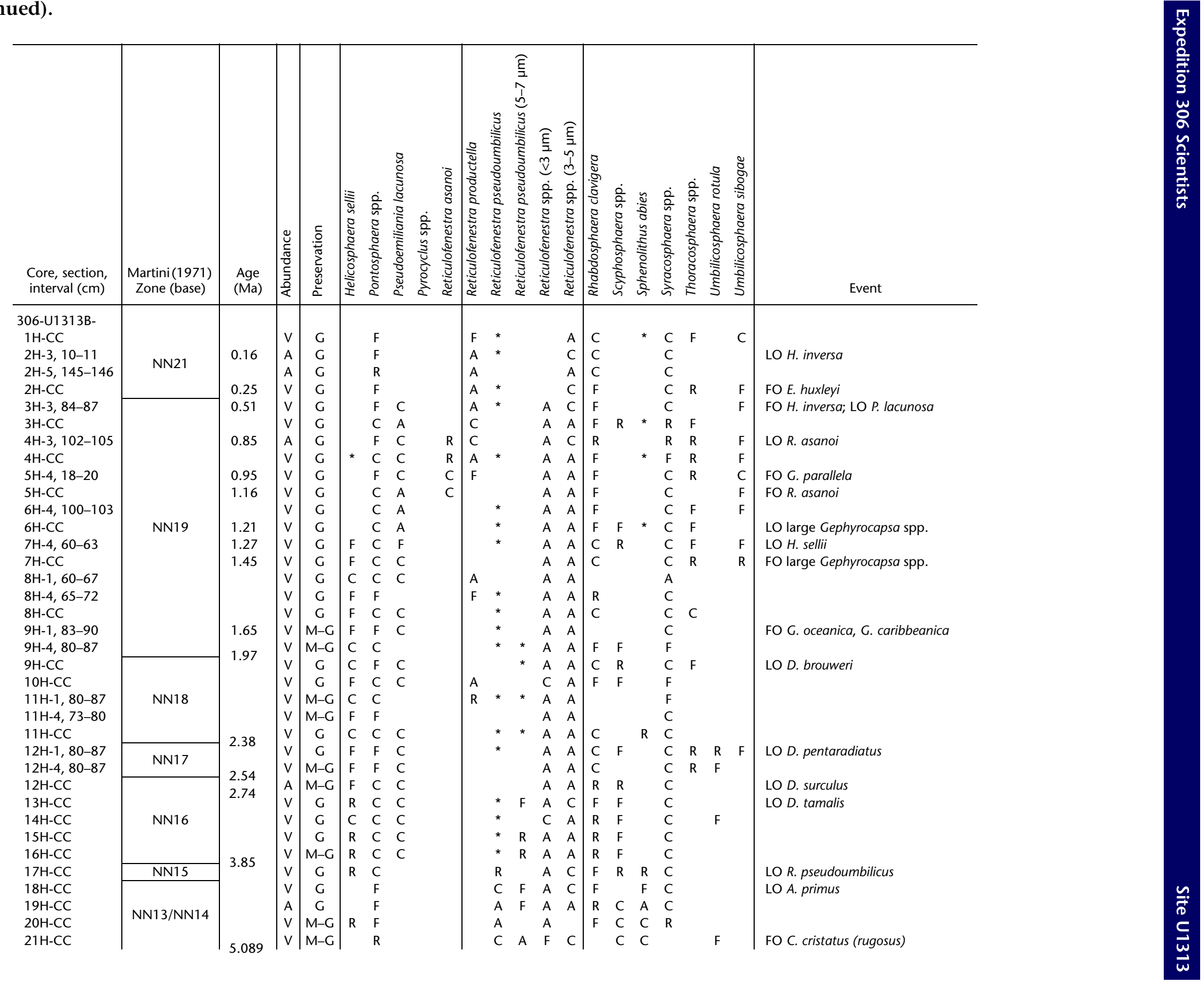
Table T6 (continued).

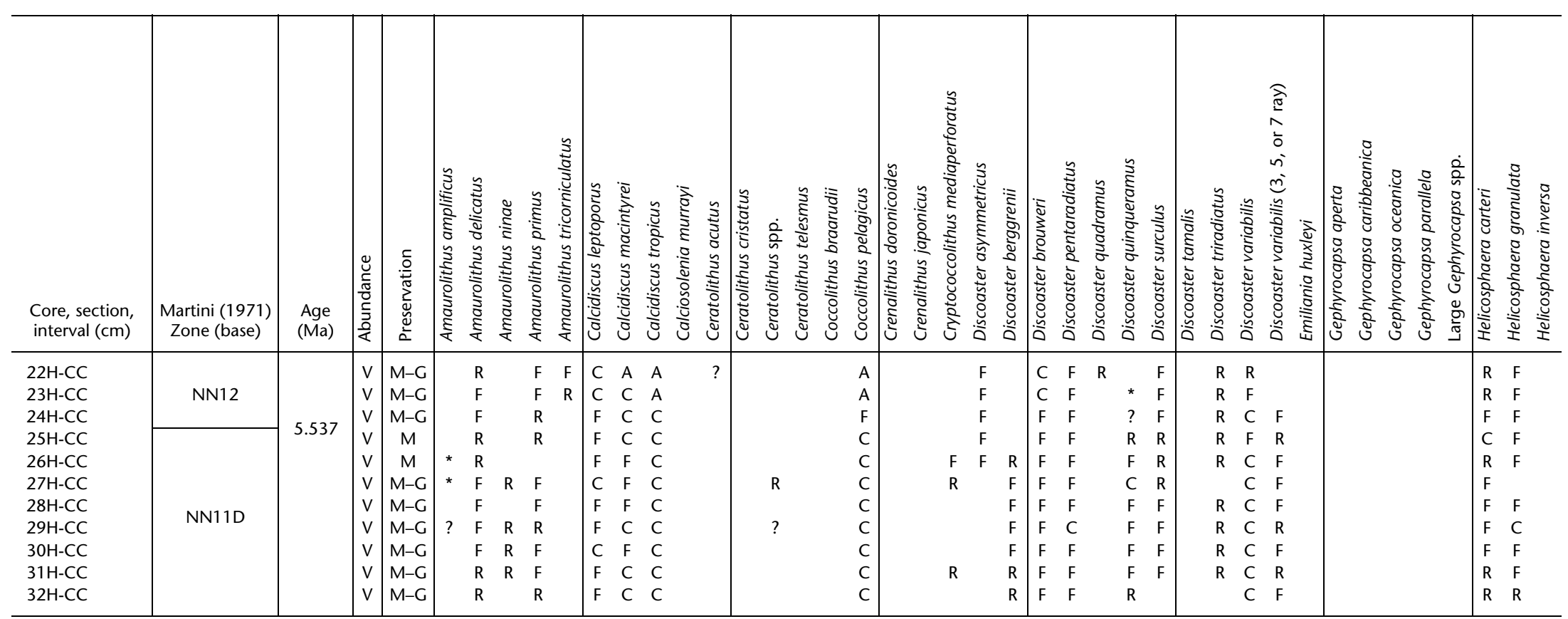

Notes: Abundance: $V=$ very abundant; $A=$ abundant; $C=$ common; $F=$ few; $R=$ rare; $P=$ present; ? = questionable; ${ }^{*}=$ reworked; Preservation: $G=$ good; $M=$ moderate; $P=$ poor. See "Calcareous nannofossils" in the "Site U1312-U1315 methods" chapter. FO = first occurrence, LO = last occurrence. 


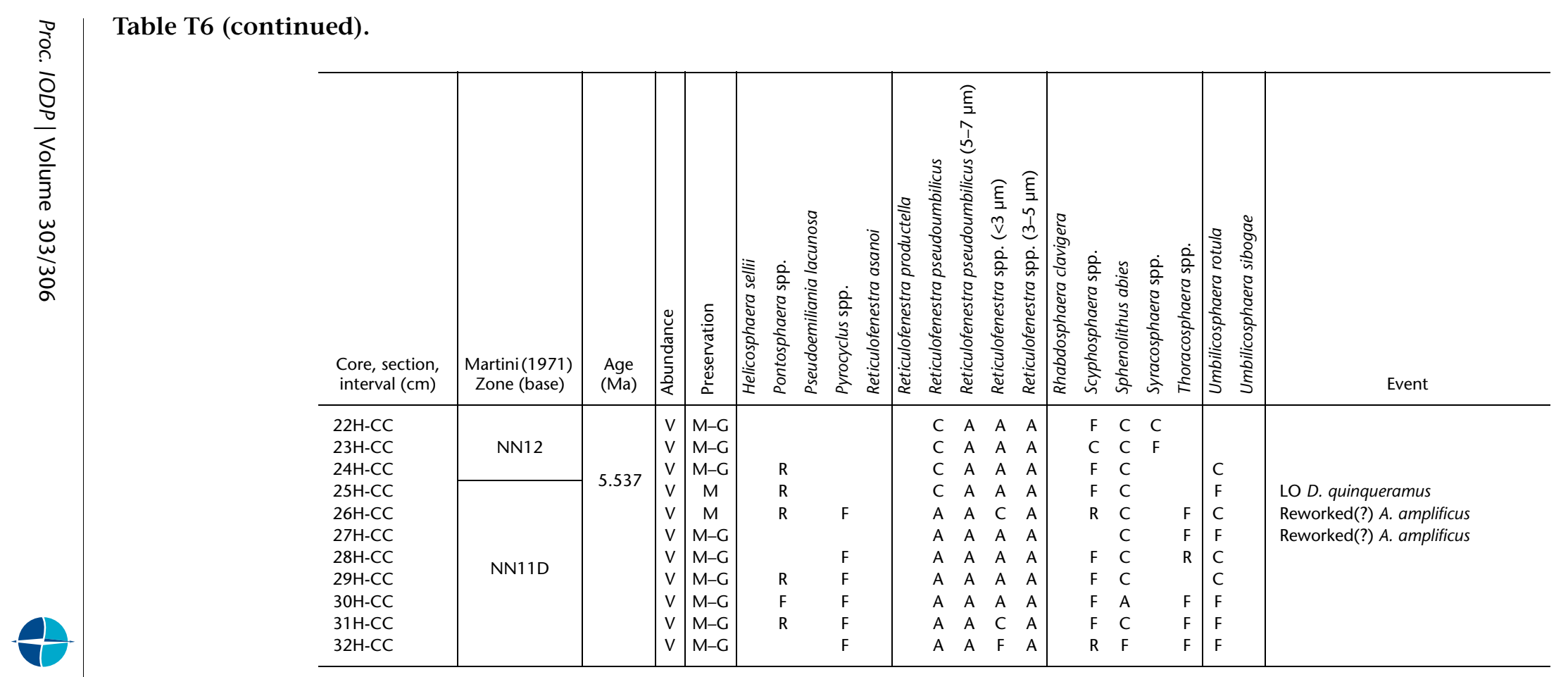




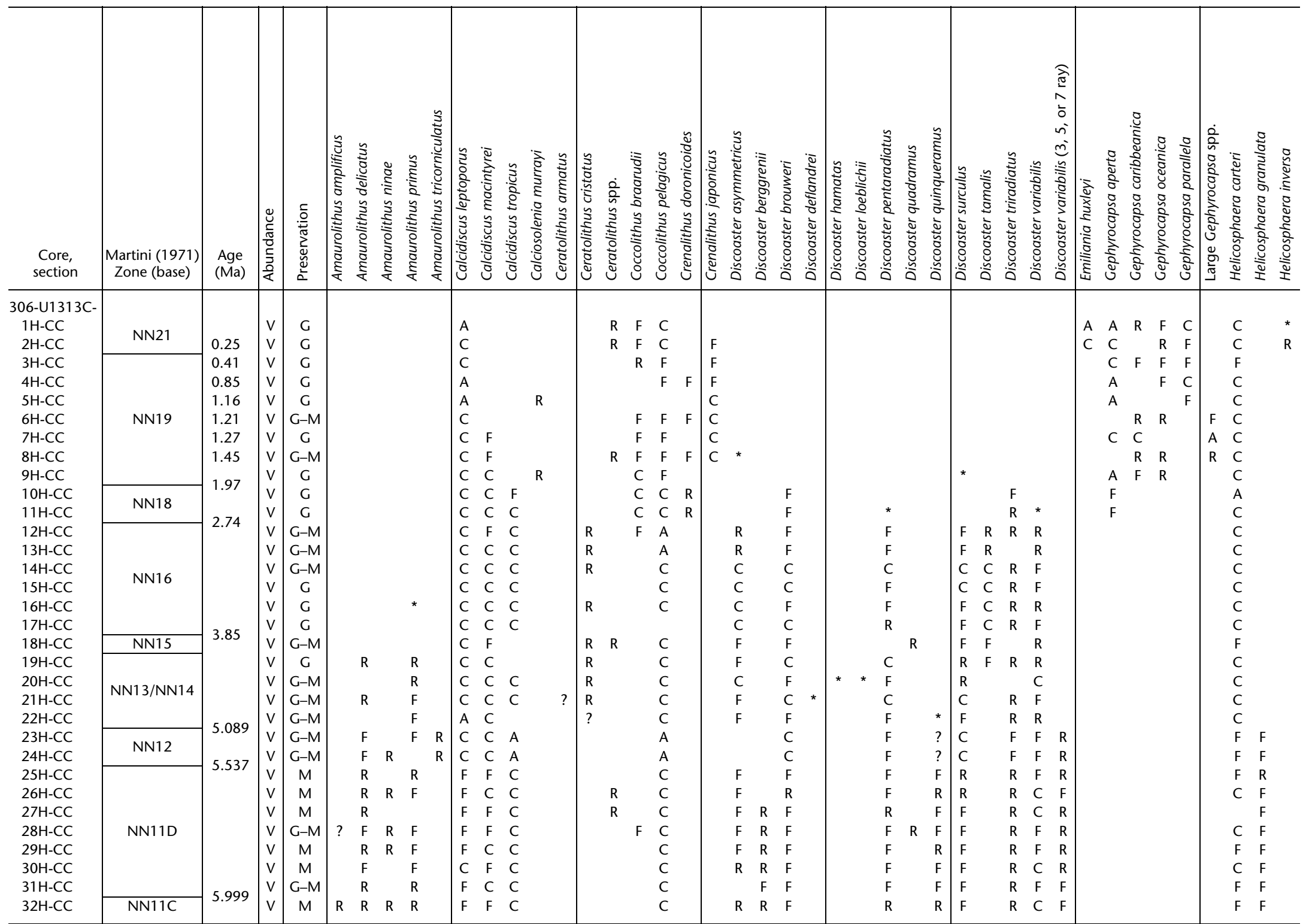

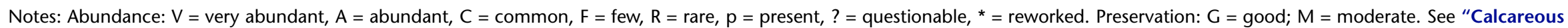




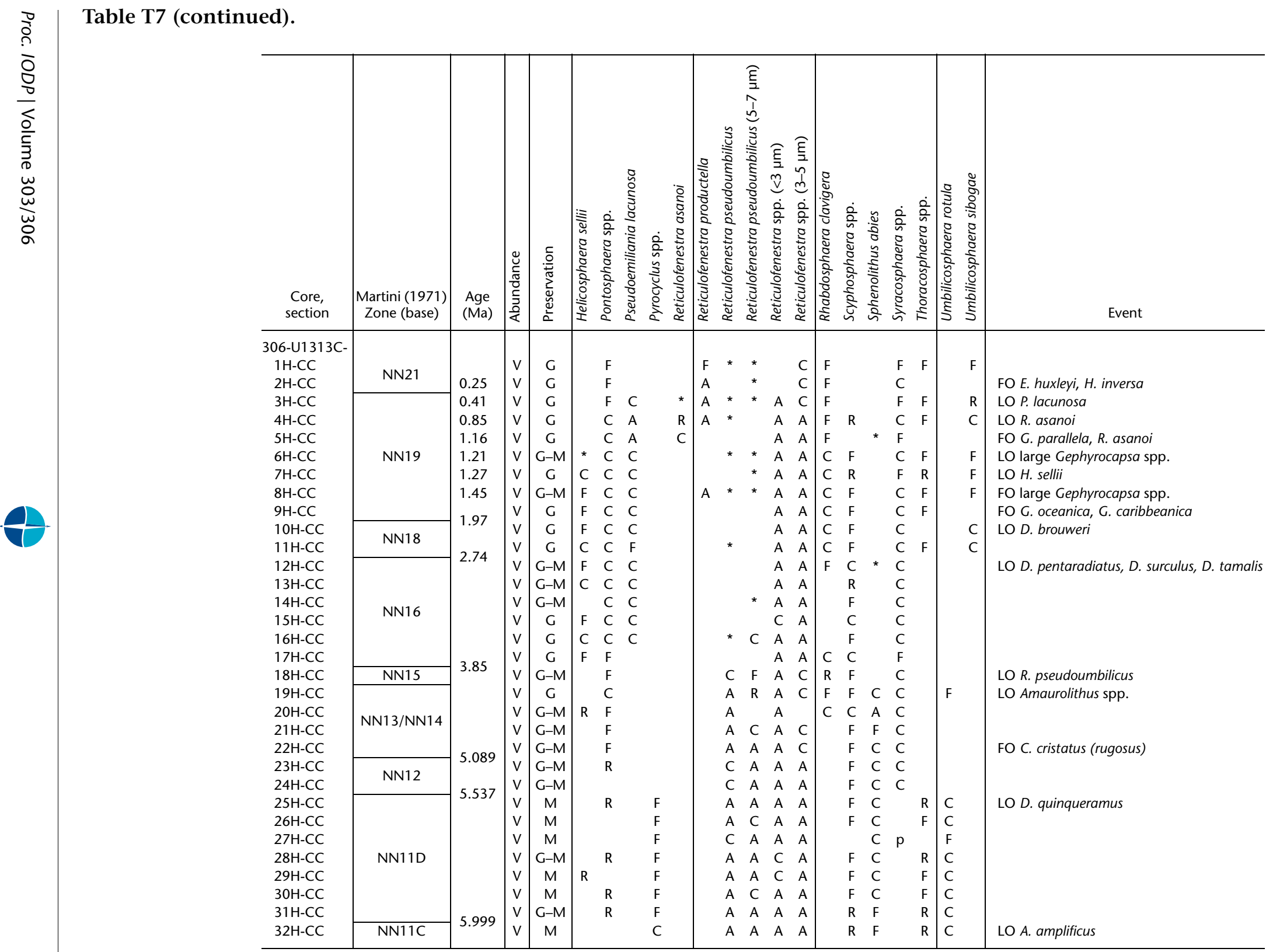



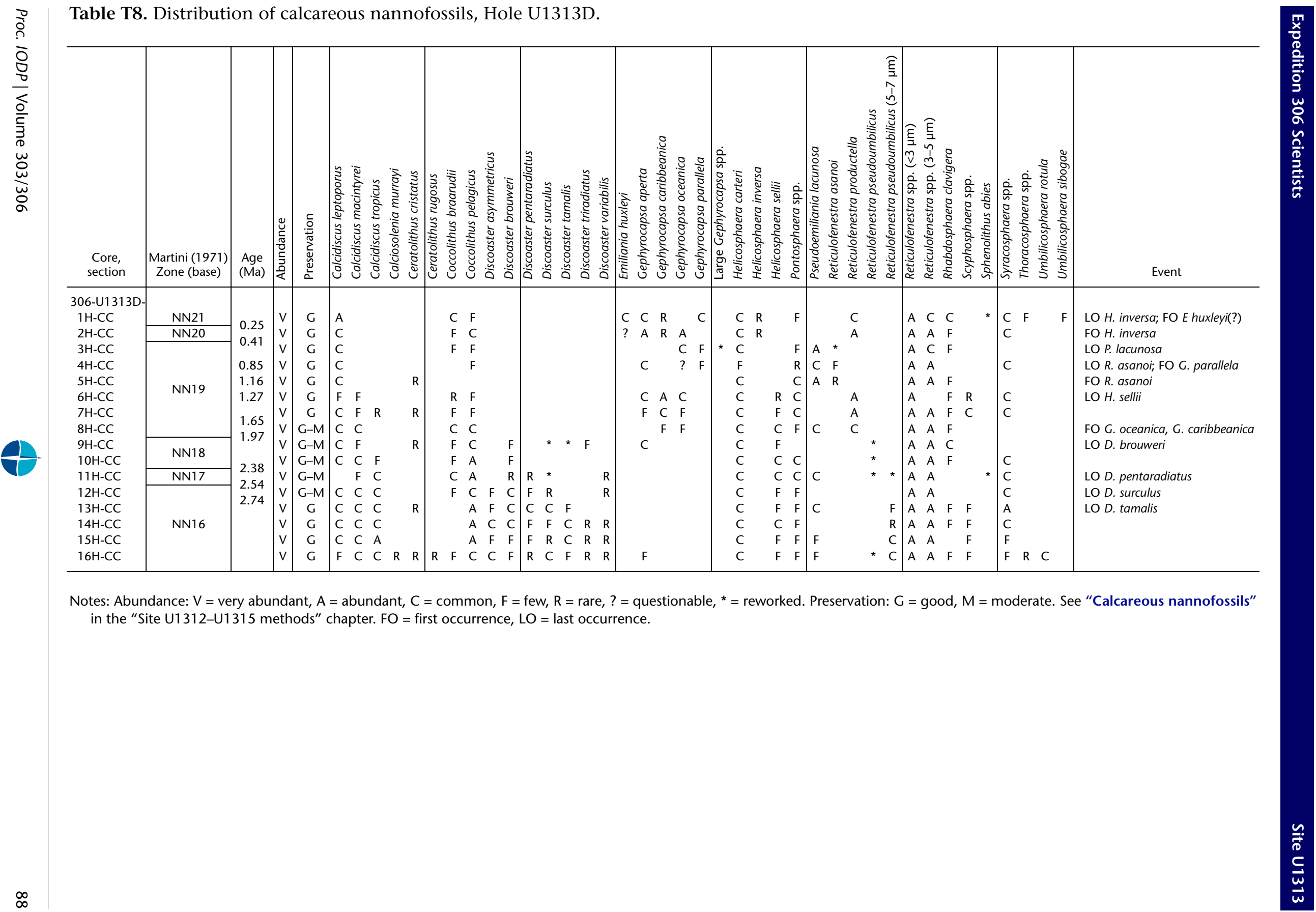

Notes: Abundance: $V=$ very abundant, $A=$ abundant, $C=$ common, $F=$ few, $R=$ rare, ? = questionable, * $=$ reworked. Preservation: $\mathrm{G}=$ good, $\mathrm{M}=$ moderate. See "Calcareous nannofossils" in the "Site U1312-U1315 methods" chapter. FO = first occurrence, LO = last occurrence. 
Table T9. Compilation of calcareous nannofossil biostratigraphic events, Holes U1313A, U1313B, U1313C, and U1313D. (See table notes. Continued on next page.)

\begin{tabular}{|c|c|c|c|c|c|c|c|}
\hline $\begin{array}{l}\text { Core, section, } \\
\text { interval }(\mathrm{cm})\end{array}$ & Species event & $\begin{array}{l}\text { Core, section, } \\
\text { interval }(\mathrm{cm})\end{array}$ & Species event & $\begin{array}{l}\text { Core, section, } \\
\text { interval }(\mathrm{cm})\end{array}$ & Species event & $\begin{array}{l}\text { Core, section, } \\
\text { interval }(\mathrm{cm})\end{array}$ & Species event \\
\hline 306-U1313A- & & 306-U1313B- & & 306-U1313C- & & 306-U1313D- & \\
\hline \multirow[t]{2}{*}{$1 \mathrm{H}-\mathrm{CC}$} & LO Helicosphaera inversa $(0.16 \mathrm{Ma})$ & $1 \mathrm{H}-\mathrm{CC}$ & & $1 \mathrm{H}-\mathrm{CC}$ & & $1 \mathrm{H}-\mathrm{CC}$ & $\begin{array}{l}\text { LO Helicosphaera inversa }(0.16 \mathrm{Ma}) \\
\text { FO Emiliania huxleyi }(0.25 \mathrm{Ma})\end{array}$ \\
\hline & & $2 \mathrm{H}-3,10-11$ & LO Helicosphaera inversa $(0.16 \mathrm{Ma})$ & & & $2 \mathrm{H}-\mathrm{CC}$ & \\
\hline $2 \mathrm{H}-\mathrm{CC}$ & & $2 \mathrm{H}-\mathrm{CC}$ & FO Emiliania huxleyi (0.25 Ma) & $2 \mathrm{H}-\mathrm{CC}$ & $\begin{array}{l}\text { FO/LO Helicosphaera inversa }(0.16 \mathrm{Ma}) \\
\text { FO Emiliania huxleyi }(0.25 \mathrm{Ma})\end{array}$ & & FO Helicosphaera inversa $(0.51 \mathrm{Ma})$ \\
\hline \multirow[t]{2}{*}{$3 \mathrm{H}-2$, top } & $\begin{array}{l}\text { FO Emiliania huxleyi }(0.25 \mathrm{Ma}) \\
\text { FO Helicosphaera inversa }(0.51 \mathrm{Ma})\end{array}$ & & & & & $3 \mathrm{H}-\mathrm{CC}$ & \\
\hline & & $3 \mathrm{H}-3,84-87$ & $\begin{array}{l}\text { LO Pseudoemiliania lacunosa }(0.41 \mathrm{Ma}) \\
\text { FO Helicosphaera inversa }(0.51 \mathrm{Ma})\end{array}$ & & & & \\
\hline $3 \mathrm{H}-5$, top & LO Pseudoemiliania lacunosa (0.41 Ma) & & & & & & \\
\hline \multirow[t]{2}{*}{$3 \mathrm{H}-\mathrm{CC}$} & LO Reticulofenestra asanoi (0.85 Ma) & $3 \mathrm{H}-\mathrm{CC}$ & & $3 \mathrm{H}-\mathrm{CC}$ & LO Pseudoemiliania lacunosa (0.41 Ma) & & LO Pseudoemiliania lacunosa $(0.41 \mathrm{Ma})$ \\
\hline & & $4 \mathrm{H}-3,102-105$ & LO Reticulofenestra asanoi (0.85 Ma) & & & $4 \mathrm{H}-\mathrm{CC}$ & \\
\hline \multirow[t]{2}{*}{$4 \mathrm{H}-\mathrm{CC}$} & FO Gephyrocapsa parallela (0.95 Ma) & $4 \mathrm{H}-\mathrm{CC}$ & & $4 \mathrm{H}-\mathrm{CC}$ & LO Reticulofenestra asanoi (0.85 Ma) & & $\begin{array}{l}\text { LO Reticulofenestra asanoi }(0.85 \mathrm{Ma}) \\
\text { FO Gephyrocapsa parallela }(0.95 \mathrm{Ma})\end{array}$ \\
\hline & & $5 \mathrm{H}-4,18-20$ & FO Gephyrocapsa parallela (0.95 Ma) & & & $5 \mathrm{H}-\mathrm{CC}$ & \\
\hline $5 \mathrm{H}-\mathrm{CC}$ & FO Reticulofenestra asanoi (1.16 Ma) & $5 \mathrm{H}-\mathrm{CC}$ & FO Reticulofenestra asanoi (1.16 Ma) & $5 \mathrm{H}-\mathrm{CC}$ & $\begin{array}{l}\text { FO Gephyrocapsa parallela }(0.95 \mathrm{Ma}) \\
\text { FO Reticulofenestra asanoi }(1.16 \mathrm{Ma})\end{array}$ & & FO Reticulofenestra asanoi (1.16 Ma) \\
\hline $6 \mathrm{H}-6,57$ & LO large Gephyrocapsa spp. (1.21 Ma) & & & & & $6 \mathrm{H}-\mathrm{CC}$ & \\
\hline \multirow[t]{2}{*}{$6 \mathrm{H}-\mathrm{CC}$} & & $6 \mathrm{H}-\mathrm{CC}$ & LO large Gephyrocapsa spp. (1.21 Ma) & $6 \mathrm{H}-\mathrm{CC}$ & LO large Gephyrocapsa spp. (1.21 Ma) & & LO Helicosphaera sellii (1.27 Ma) \\
\hline & & $7 \mathrm{H}-4,60-63$ & LO Helicosphaera sellii (1.27 Ma) & & & 7H-CC & \\
\hline 7H-CC & $\begin{array}{l}\text { LO Helicosphaera sellii (1.27 Ma) } \\
\text { FO large Gephyrocapsa spp. (1.45 Ma) }\end{array}$ & $7 \mathrm{H}-\mathrm{CC}$ & FO large Gephyrocapsa spp. (1.45 Ma) & 7H-CC & LO Helicosphaera sellii (1.27 Ma) & & \\
\hline \multirow[t]{2}{*}{$8 \mathrm{H}-\mathrm{CC}$} & $\begin{array}{l}\text { FO Gephyrocapsa oceanica }(1.65 \mathrm{Ma}) \\
\text { FO Gephyrocapsa caribbeanica } \\
(1.73 \mathrm{Ma})\end{array}$ & $8 \mathrm{H}-\mathrm{CC}$ & & $8 \mathrm{H}-\mathrm{CC}$ & FO large Gephyrocapsa spp. (1.45 Ma) & $8 \mathrm{H}-\mathrm{CC}$ & $\begin{array}{l}\text { FO Gephyrocapsa oceanica }(1.65 \mathrm{Ma}) \\
\text { FO Gephyrocapsa caribbeanica } \\
(1.73 \mathrm{Ma})\end{array}$ \\
\hline & & $9 \mathrm{H}-1,83-90$ & $\begin{array}{l}\text { FO Gephyrocapsa oceanica }(1.65 \mathrm{Ma}) \\
\text { FO Gephyrocapsa caribbeanica } \\
(1.73 \mathrm{Ma})\end{array}$ & & & $9 \mathrm{H}-\mathrm{CC}$ & \\
\hline $9 \mathrm{H}-\mathrm{CC}$ & & $9 \mathrm{H}-\mathrm{CC}$ & LO Discoaster brouweri (1.97 Ma) & $9 \mathrm{H}-\mathrm{CC}$ & $\begin{array}{l}\text { FO Gephyrocapsa oceanica }(1.65 \mathrm{Ma}) \\
\text { FO Gephyrocapsa caribbeanica } \\
(1.73 \mathrm{Ma})\end{array}$ & & LO Discoaster brouweri (1.97 Ma) \\
\hline $10 \mathrm{H}-\mathrm{CC}$ & LO Discoaster brouweri (1.97 Ma) & $10 \mathrm{H}-\mathrm{CC}$ & & $10 \mathrm{H}-\mathrm{CC}$ & LO Discoaster brouweri (1.97 Ma) & $10 \mathrm{H}-\mathrm{CC}$ & \\
\hline \multirow[t]{2}{*}{$11 \mathrm{H}-\mathrm{CC}$} & LO Discoaster pentaradiatus (2.38 Ma) & $11 \mathrm{H}-\mathrm{CC}$ & & $11 \mathrm{H}-\mathrm{CC}$ & & $11 \mathrm{H}-\mathrm{CC}$ & LO Discoaster pentaradiatus (2.38 Ma) \\
\hline & & $12 \mathrm{H}-1,80-87$ & LO Discoaster pentaradiatus (2.38 Ma) & & & & \\
\hline $12 \mathrm{H}-\mathrm{CC}$ & LO Discoaster surculus (2.54 Ma) & $12 \mathrm{H}-\mathrm{CC}$ & LO Discoaster surculus (2.54 Ma) & $12 \mathrm{H}-\mathrm{CC}$ & $\begin{array}{l}\text { LO Discoaster pentaradiatus }(2.38 \mathrm{Ma}) \\
\text { LO Discoaster surculus }(2.54 \mathrm{Ma}) \\
\text { LO Discoaster tamalis }(2.74 \mathrm{Ma})\end{array}$ & $12 \mathrm{H}-\mathrm{CC}$ & LO Discoaster surculus (2.54 Ma) \\
\hline $13 \mathrm{H}-\mathrm{CC}$ & LO Discoaster tamalis (2.74 Ma) & $13 \mathrm{H}-\mathrm{CC}$ & LO Discoaster tamalis (2.74 Ma) & $13 \mathrm{H}-\mathrm{CC}$ & & $13 \mathrm{H}-\mathrm{CC}$ & LO Discoaster tamalis (2.74 Ma) \\
\hline $14 \mathrm{H}-\mathrm{CC}$ & & $14 \mathrm{H}-\mathrm{CC}$ & & $14 \mathrm{H}-\mathrm{CC}$ & & $14 \mathrm{H}-\mathrm{CC}$ & \\
\hline $15 \mathrm{H}-\mathrm{CC}$ & & $15 \mathrm{H}-\mathrm{CC}$ & & $15 \mathrm{H}-\mathrm{CC}$ & & $15 \mathrm{H}-\mathrm{CC}$ & \\
\hline $16 \mathrm{H}-\mathrm{CC}$ & & $16 \mathrm{H}-\mathrm{CC}$ & & $16 \mathrm{H}-\mathrm{CC}$ & & $16 \mathrm{H}-\mathrm{CC}$ & TD \\
\hline $17 \mathrm{H}-\mathrm{CC}$ & $\begin{array}{l}\text { LO Reticulofenestra pseudoumbilicus } \\
(3.85 \mathrm{Ma})\end{array}$ & $17 \mathrm{H}-\mathrm{CC}$ & $\begin{array}{l}\text { LO Reticulofenestra pseudoumbilicus } \\
(3.85 \mathrm{Ma})\end{array}$ & $17 \mathrm{H}-\mathrm{CC}$ & & & \\
\hline $18 \mathrm{H}-\mathrm{CC}$ & LO Amaurolithus spp. (4.56 Ma?) & $18 \mathrm{H}-\mathrm{CC}$ & LO Amaurolithus spp. (4.56 Ma?) & $18 \mathrm{H}-\mathrm{CC}$ & $\begin{array}{l}\text { LO Reticulofenestra pseudoumbilicus } \\
(3.85 \mathrm{Ma})\end{array}$ & & \\
\hline $19 \mathrm{H}-\mathrm{CC}$ & & $19 \mathrm{H}-\mathrm{CC}$ & & $19 \mathrm{H}-\mathrm{CC}$ & LO Amaurolithus spp. (4.56 Ma?) & & \\
\hline $20 \mathrm{H}-\mathrm{CC}$ & & $20 \mathrm{H}-\mathrm{CC}$ & & $20 \mathrm{H}-\mathrm{CC}$ & & & \\
\hline $21 \mathrm{H}-\mathrm{CC}$ & & $21 \mathrm{H}-\mathrm{CC}$ & $\begin{array}{l}\text { FO Ceratolithus cristatus (rugosus) } \\
(5.089 \mathrm{Ma})\end{array}$ & $21 \mathrm{H}-\mathrm{CC}$ & & & \\
\hline $22 \mathrm{H}-\mathrm{CC}$ & & $22 \mathrm{H}-\mathrm{CC}$ & & $22 \mathrm{H}-\mathrm{CC}$ & $\begin{array}{l}\text { FO Ceratolithus cristatus (rugosus) } \\
(5.089 \mathrm{Ma})\end{array}$ & & \\
\hline
\end{tabular}


Table T9 (continued).

\begin{tabular}{|c|c|c|c|c|c|c|c|}
\hline $\begin{array}{l}\text { Core, section, } \\
\text { interval }(\mathrm{cm})\end{array}$ & Species event & $\begin{array}{l}\text { Core, section, } \\
\text { interval }(\mathrm{cm})\end{array}$ & Species event & $\begin{array}{l}\text { Core, section, } \\
\text { interval }(\mathrm{cm})\end{array}$ & Species event & $\begin{array}{l}\text { Core, section, } \\
\text { interval }(\mathrm{cm})\end{array}$ & Species event \\
\hline $23 \mathrm{H}-\mathrm{CC}$ & $\begin{array}{l}\text { FO Ceratolithus cristatus (rugosus) } \\
(5.089 \mathrm{Ma})\end{array}$ & $23 \mathrm{H}-\mathrm{CC}$ & & $23 \mathrm{H}-\mathrm{CC}$ & & & \\
\hline $24 \mathrm{H}-\mathrm{CC}$ & & $24 \mathrm{H}-\mathrm{CC}$ & & $24 \mathrm{H}-\mathrm{CC}$ & & & \\
\hline $25 \mathrm{H}-\mathrm{CC}$ & $\begin{array}{l}\text { LO Discoaster quinqueramus ( } 5.537 \\
\mathrm{Ma} \text { ) }\end{array}$ & $25 \mathrm{H}-\mathrm{CC}$ & LO Discoaster quinqueramus (5.537 Ma) & $25 \mathrm{H}-\mathrm{CC}$ & $\begin{array}{l}\text { LO Discoaster quinqueramus } \\
(5.537 \mathrm{Ma})\end{array}$ & & \\
\hline $26 \mathrm{H}-\mathrm{CC}$ & & $26 \mathrm{H}-\mathrm{CC}$ & & $26 \mathrm{H}-\mathrm{CC}$ & & & \\
\hline $27 \mathrm{H}-\mathrm{CC}$ & & $27 \mathrm{H}-\mathrm{CC}$ & & $27 \mathrm{H}-\mathrm{CC}$ & & & \\
\hline $28 \mathrm{H}-\mathrm{CC}$ & & $28 \mathrm{H}-\mathrm{CC}$ & & $28 \mathrm{H}-\mathrm{CC}$ & & & \\
\hline $29 \mathrm{H}-\mathrm{CC}$ & & $29 \mathrm{H}-\mathrm{CC}$ & & $29 \mathrm{H}-\mathrm{CC}$ & & & \\
\hline $30 \mathrm{H}-\mathrm{CC}$ & & $30 \mathrm{H}-\mathrm{CC}$ & & $30 \mathrm{H}-\mathrm{CC}$ & & & \\
\hline $31 \mathrm{H}-\mathrm{CC}$ & & $31 \mathrm{H}-\mathrm{CC}$ & & $31 \mathrm{H}-\mathrm{CC}$ & & & \\
\hline $32 \mathrm{H}-\mathrm{CC}$ & LO Amaurolithus amplificus (5.999 Ma) & $32 \mathrm{H}-\mathrm{CC}$ & TD & $32 \mathrm{H}-\mathrm{CC}$ & $\begin{array}{l}\text { LO Amaurolithus amplificus } \\
(5.999 \mathrm{Ma}) ; \mathrm{TD}\end{array}$ & & \\
\hline $33 \mathrm{H}-\mathrm{CC}$ & TD & & & & & & \\
\hline
\end{tabular}

Notes: Shaded areas indicate samples from within cores that were not examined in the corresponding hole. $F O=$ first occurrence, $L O=$ last occurrence, $T D=$ total depth. 
Table T10. Compilation of planktonic foraminifer biostratigraphic events, Holes U1313A, U1313B, U1313C, and U1313D.

\begin{tabular}{|c|c|c|c|c|c|c|c|}
\hline Core & Species event & Core & Species event & Core & Species event & Core & Species event \\
\hline 306-U13 & 313A- & $306-U 13$ & 13B- & 306-U1 & 313C- & 306-U1 & 313D- \\
\hline $5 \mathrm{H}$ & & $5 \mathrm{H}$ & & $5 \mathrm{H}$ & $\begin{array}{l}\text { FaO Neogloboquadrina pachyderma (s) } \\
\text { encrusted (1.78 Ma) }\end{array}$ & $5 \mathrm{H}$ & $\begin{array}{l}\text { FcO Neogloboquadrina pachyderma (s) } \\
\text { encrusted (1.78 Ma) }\end{array}$ \\
\hline $6 \mathrm{H}$ & & $6 \mathrm{H}$ & & $6 \mathrm{H}$ & & $6 \mathrm{H}$ & $\begin{array}{l}\text { LO Neogloboquadrina atlantica (d) (1.4-1.5 } \\
\text { Ma) }\end{array}$ \\
\hline $7 \mathrm{H}$ & $\begin{array}{l}\text { LO Neogloboquadrina atlantica }(\mathrm{d}) \\
(1.4-1.5 \mathrm{Ma})\end{array}$ & $7 \mathrm{H}$ & $\begin{array}{l}\text { LO Neogloboquadrina atlantica }(\mathrm{d}) \\
(1.4-1.5 \mathrm{Ma})\end{array}$ & $7 \mathrm{H}$ & LO Neogloboquadrina atlantica (d) (1.4-1.5 Ma) & $7 \mathrm{H}$ & \\
\hline $8 \mathrm{H}$ & $\begin{array}{l}\text { FaO Neogloboquadrina pachyderma (s) } \\
\text { encrusted (1.78) Ma }\end{array}$ & $8 \mathrm{H}$ & FO Globorotalia truncatulinoides (2.08 Ma) & $8 \mathrm{H}$ & FO Globorotalia truncatulinoides (2.08 Ma) & $8 \mathrm{H}$ & \\
\hline $9 \mathrm{H}$ & & $9 \mathrm{H}$ & & $9 \mathrm{H}$ & FO Globorotalia inflata (2.09 Ma) & $9 \mathrm{H}$ & FO Globorotalia truncatulinoides (2.08 Ma) \\
\hline $10 \mathrm{H}$ & FO Globorotalia inflata (2.09 Ma) & $10 \mathrm{H}$ & FO Globorotalia inflata (2.09 Ma) & $10 \mathrm{H}$ & & $10 \mathrm{H}$ & FO Globorotalia inflata (2.09 Ma) \\
\hline $11 \mathrm{H}$ & LO Globorotalia miocenica (2.4 Ma) & $11 \mathrm{H}$ & & $11 \mathrm{H}$ & LO Globorotalia puncticulata (2.41 Ma) & $11 \mathrm{H}$ & LO Neogloboquadrina atlantica (s) (2.41 Ma) \\
\hline $12 \mathrm{H}$ & LO Globorotalia puncticulata (2.41 Ma) & $12 \mathrm{H}$ & $\begin{array}{l}\text { LO Globorotalia puncticulata }(2.41 \mathrm{Ma}) \\
\text { LO Neogloboquadrina atlantica }(\mathrm{s})(2.41 \mathrm{Ma})\end{array}$ & $12 \mathrm{H}$ & LO Neogloboquadrina atlantica (s) (2.41 Ma) & $12 \mathrm{H}$ & $\begin{array}{l}\text { LO Globorotalia miocenica }(2.4 \mathrm{Ma}) \\
\text { LO Globorotalia puncticulata }(2.41 \mathrm{Ma})\end{array}$ \\
\hline $13 \mathrm{H}$ & & $13 \mathrm{H}$ & LO Globorotalia miocenica (2.4 Ma) & $13 \mathrm{H}$ & & $13 \mathrm{H}$ & \\
\hline $14 \mathrm{H}$ & & $14 \mathrm{H}$ & $\begin{array}{l}\text { Reappearance Neogloboquadrina } \\
\text { puncticulata }(3.31 \mathrm{Ma})\end{array}$ & $14 \mathrm{H}$ & LO Globorotalia miocenica (2.4 Ma) & $14 \mathrm{H}$ & \\
\hline $15 \mathrm{H}$ & $\begin{array}{l}\text { Disappearance Globorotalia hirsuta } \\
\text { LO Sphaeroidinellopsis seminulina } \\
\text { (3.18-3.19 Ma) } \\
\text { Reappearance Globorotalia puncticulata } \\
(3.31 \mathrm{Ma})\end{array}$ & $15 \mathrm{H}$ & $\begin{array}{l}\text { Disappearance Globorotalia hirsuta } \\
\text { LO Sphaeroidinellopsis seminulina } \\
\text { (3.18-3.19 Ma) }\end{array}$ & $15 \mathrm{H}$ & $\begin{array}{l}\text { LO Sphaeroidinellopsis seminulina ( } 3.19 \mathrm{Ma}) \\
\text { Reappearance Globorotalia puncticulata } \\
(3.31 \mathrm{Ma})\end{array}$ & $15 \mathrm{H}$ & Disappearance Globorotalia hirsuta (3.18 Ma) \\
\hline $16 \mathrm{H}$ & & $16 \mathrm{H}$ & $\begin{array}{l}\text { Disappearance Globorotalia puncticulata } \\
(3.57 \mathrm{Ma})\end{array}$ & $16 \mathrm{H}$ & Disappearance Globorotalia hirsuta (3.18 Ma) & $16 \mathrm{H}$ & \\
\hline $17 \mathrm{H}$ & $\begin{array}{l}\text { Disappearance Globorotalia puncticulata } \\
(3.57 \mathrm{Ma})\end{array}$ & $17 \mathrm{H}$ & & $17 \mathrm{H}$ & $\begin{array}{l}\text { Disappearance Globorotalia puncticulata } \\
(3.57 \mathrm{Ma})\end{array}$ & & \\
\hline $18 \mathrm{H}$ & LO Globorotalia margaritae (3.81 Ma) & $18 \mathrm{H}$ & LO Globorotalia margaritae (3.81 Ma) & $18 \mathrm{H}$ & & & \\
\hline $19 \mathrm{H}$ & LcO Globorotalia margaritae (3.98 Ma) & $19 \mathrm{H}$ & LcO Globorotalia margaritae (3.98 Ma) & $19 \mathrm{H}$ & LO Globorotalia margaritae (3.81 Ma) & & \\
\hline $20 \mathrm{H}$ & $\begin{array}{l}\text { FO Globorotalia puncticulata and } \\
\text { Globorotalia crassaformis (4.52 Ma) }\end{array}$ & $20 \mathrm{H}$ & $\begin{array}{l}\text { FO Globorotalia puncticulata and Globorotalia } \\
\text { crassaformis (4.52 Ma) }\end{array}$ & $20 \mathrm{H}$ & LcO Globorotalia margaritae (3.98 Ma) & & \\
\hline $21 \mathrm{H}$ & & $21 \mathrm{H}$ & & $21 \mathrm{H}$ & $\begin{array}{l}\text { FO Globorotalia puncticulata and Globorotalia } \\
\text { crassaformis ( } 4.52 \mathrm{Ma})\end{array}$ & & \\
\hline $22 \mathrm{H}$ & LO Globigerina nepenthes (4.8-4.89 Ma) & $22 \mathrm{H}$ & LO Globigerina nepenthes (4.8-4.89 Ma) & $22 \mathrm{H}$ & & & \\
\hline $23 \mathrm{H}$ & & $23 \mathrm{H}$ & & $23 \mathrm{H}$ & LO Globigerina nepenthes (4.8-4.89 Ma) & & \\
\hline $\begin{array}{l}32 \mathrm{H} \\
33 \mathrm{H}\end{array}$ & LaO Globorotalia margaritae (?) & $32 \mathrm{H}$ & & $32 \mathrm{H}$ & & & \\
\hline
\end{tabular}

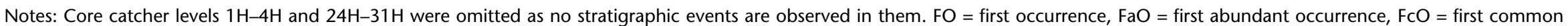
occurrence, $\mathrm{LO}=$ last occurrence, $\mathrm{LaO}=$ last abundant occurrence, $\mathrm{LcO}=$ last common occurrence. $\mathrm{d}=$ dextral, $\mathrm{s}=$ sinistral. 


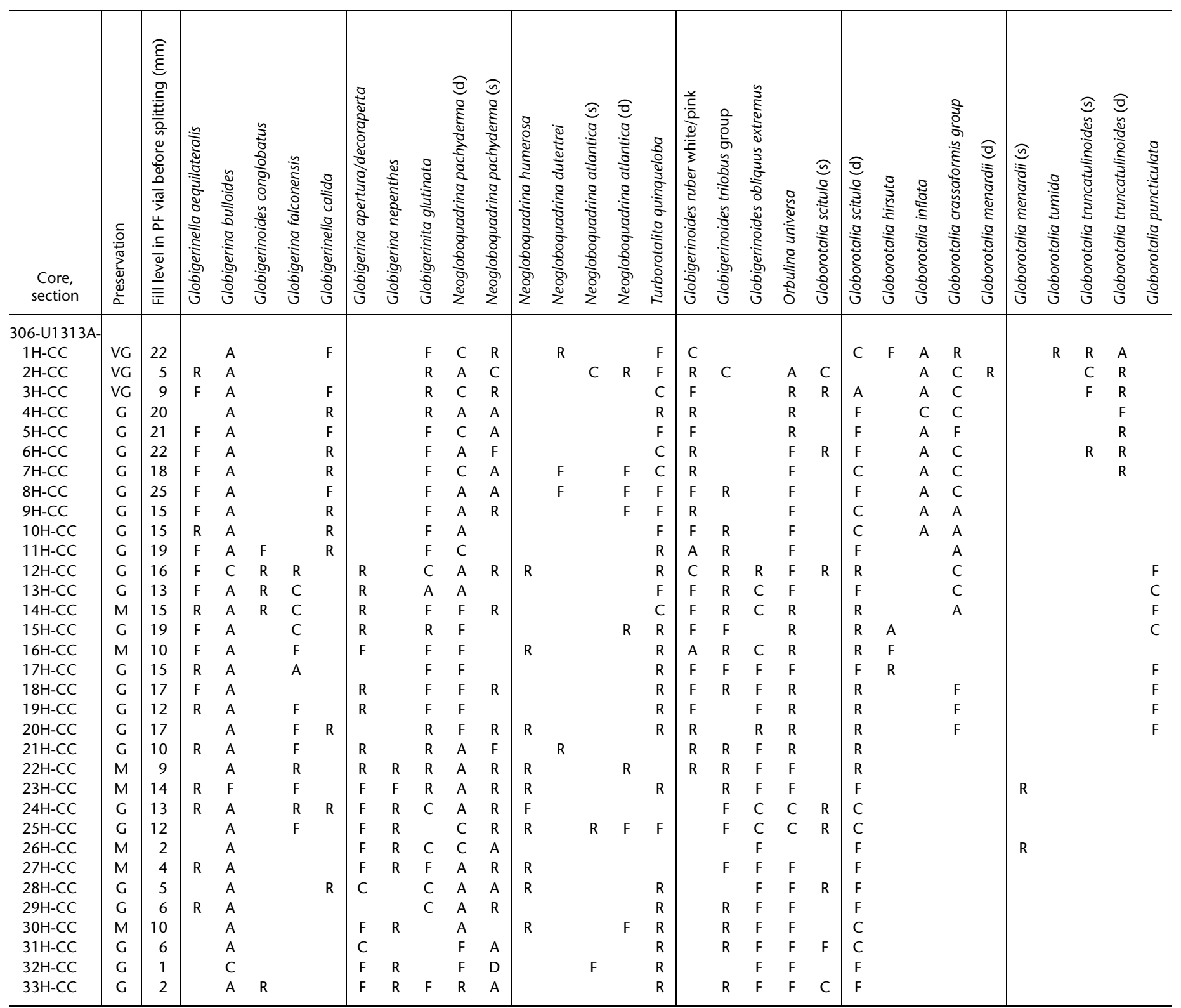

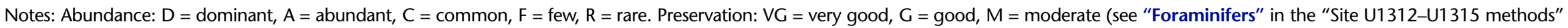




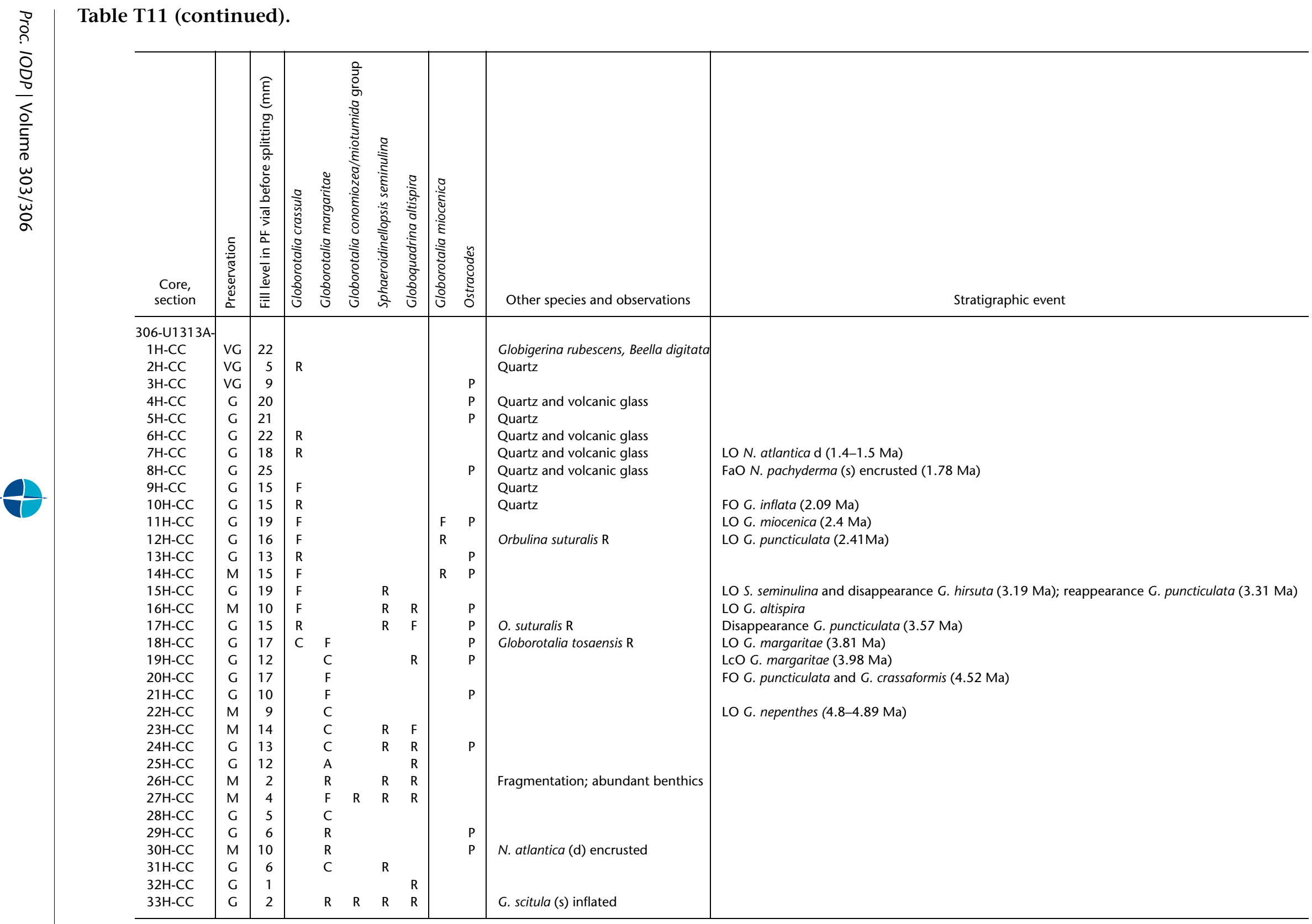




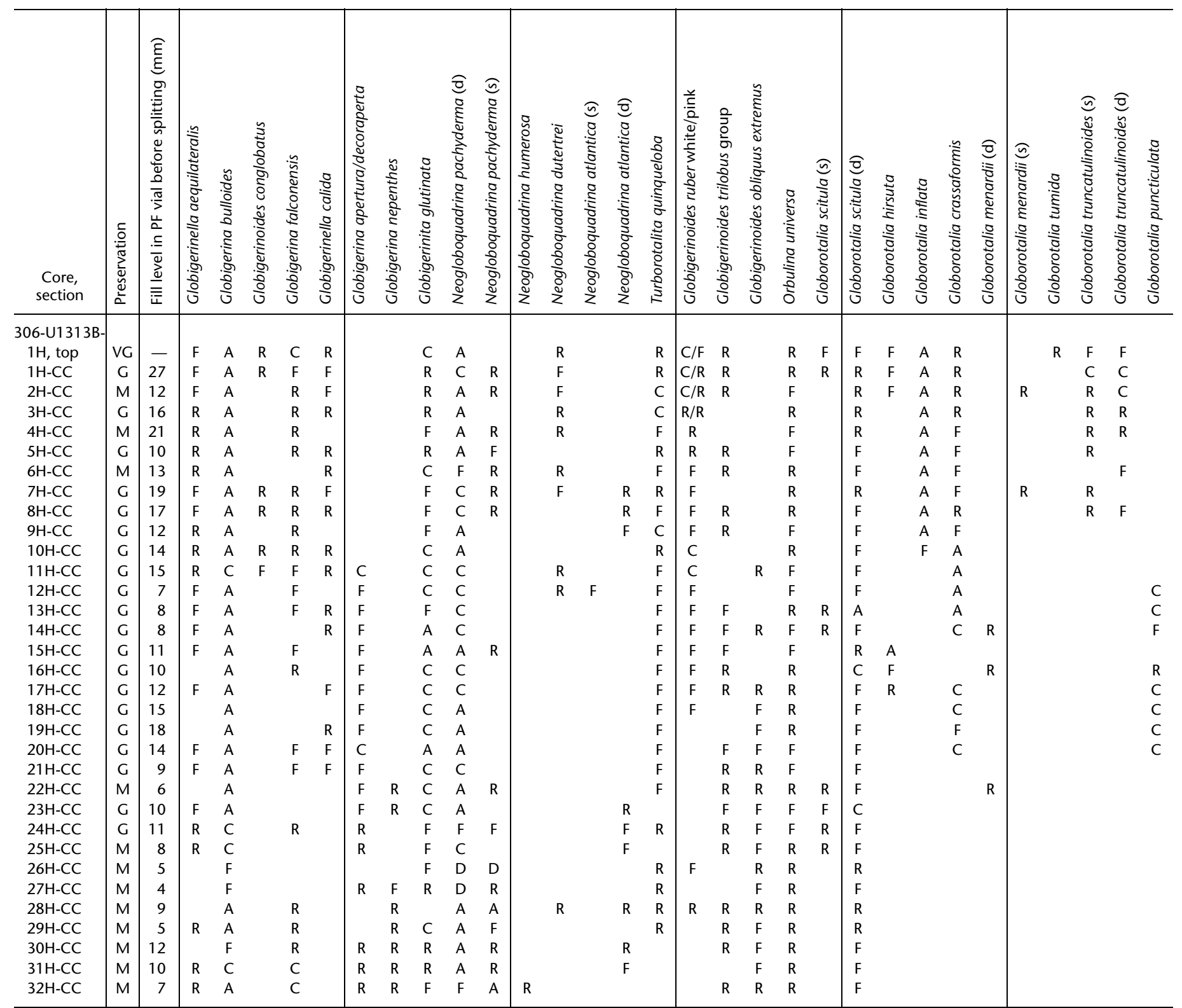

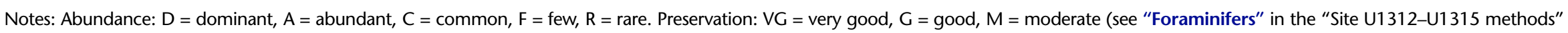



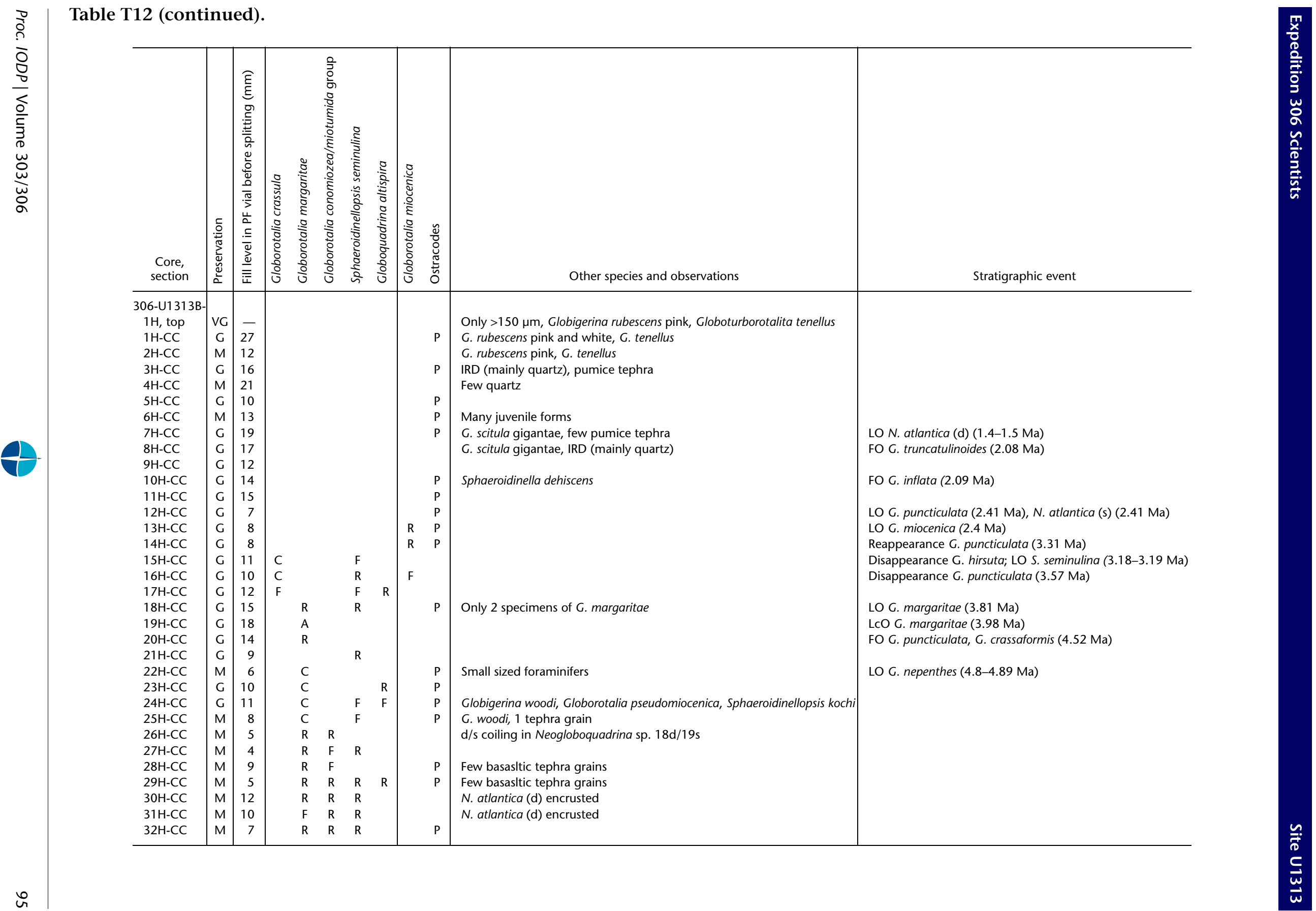


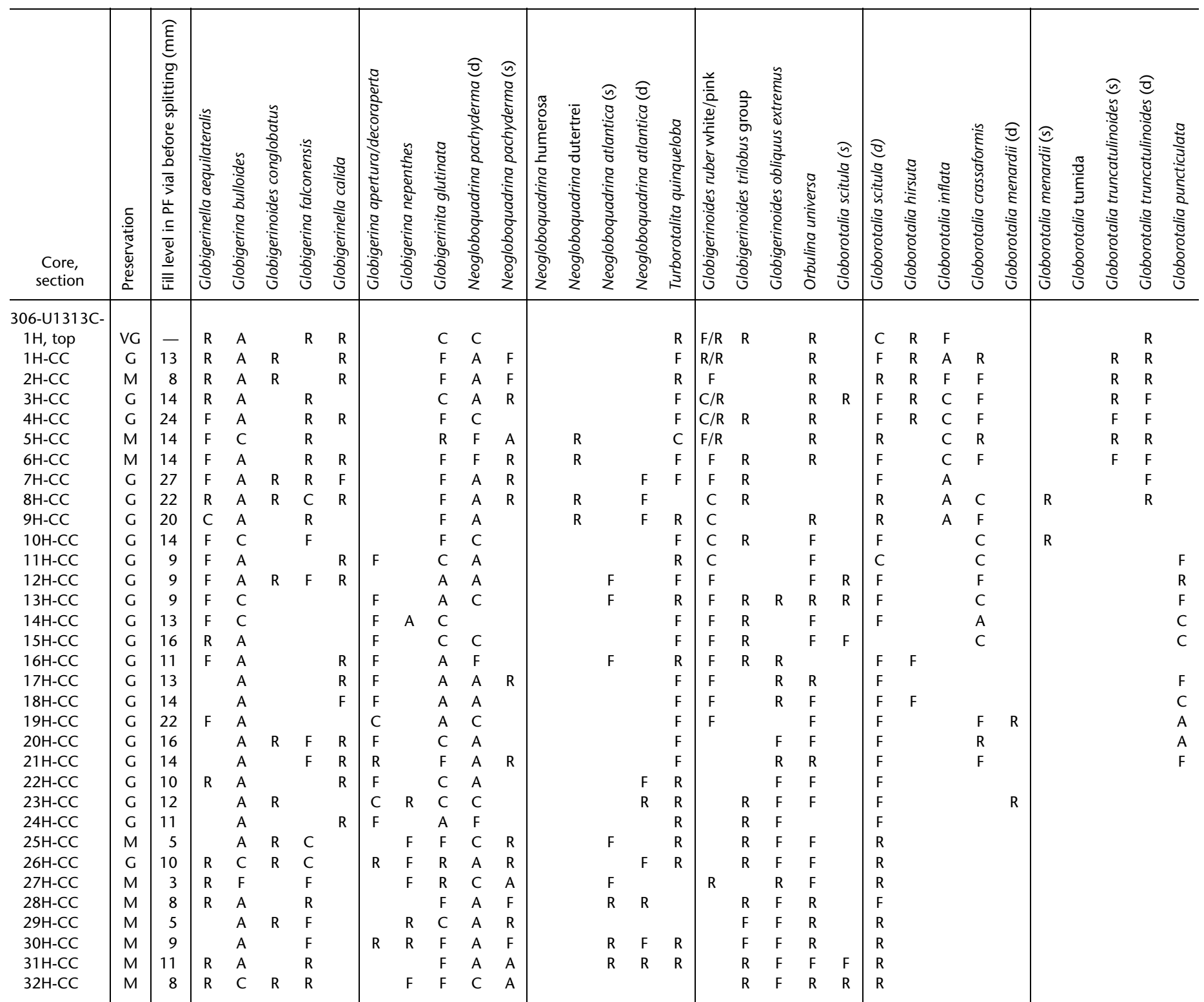

Notes: Abundance: $\mathrm{A}=$ abundant, $\mathrm{C}=$ common, $\mathrm{F}=$ few, $\mathrm{R}=$ rare. Preservation: $\mathrm{VG}=$ very good, $\mathrm{G}=$ good, $\mathrm{M}=$ moderate (see "Foraminifers" in the "Site U1312-U1315 methods" chapter). PF = planktonic foraminifers. $\mathrm{d}=$ dextral, $\mathrm{s}=$ sinistral. $\mathrm{P}$ in ostracodes column $=$ presence of valves. IRD = ice-rafted debris, $\mathrm{FO}=$ first occurrence, FaO $=$ first abundant occurrence, $\mathrm{LO}=$ last occurrence, $\mathrm{LcO}=\mathrm{last}$ 

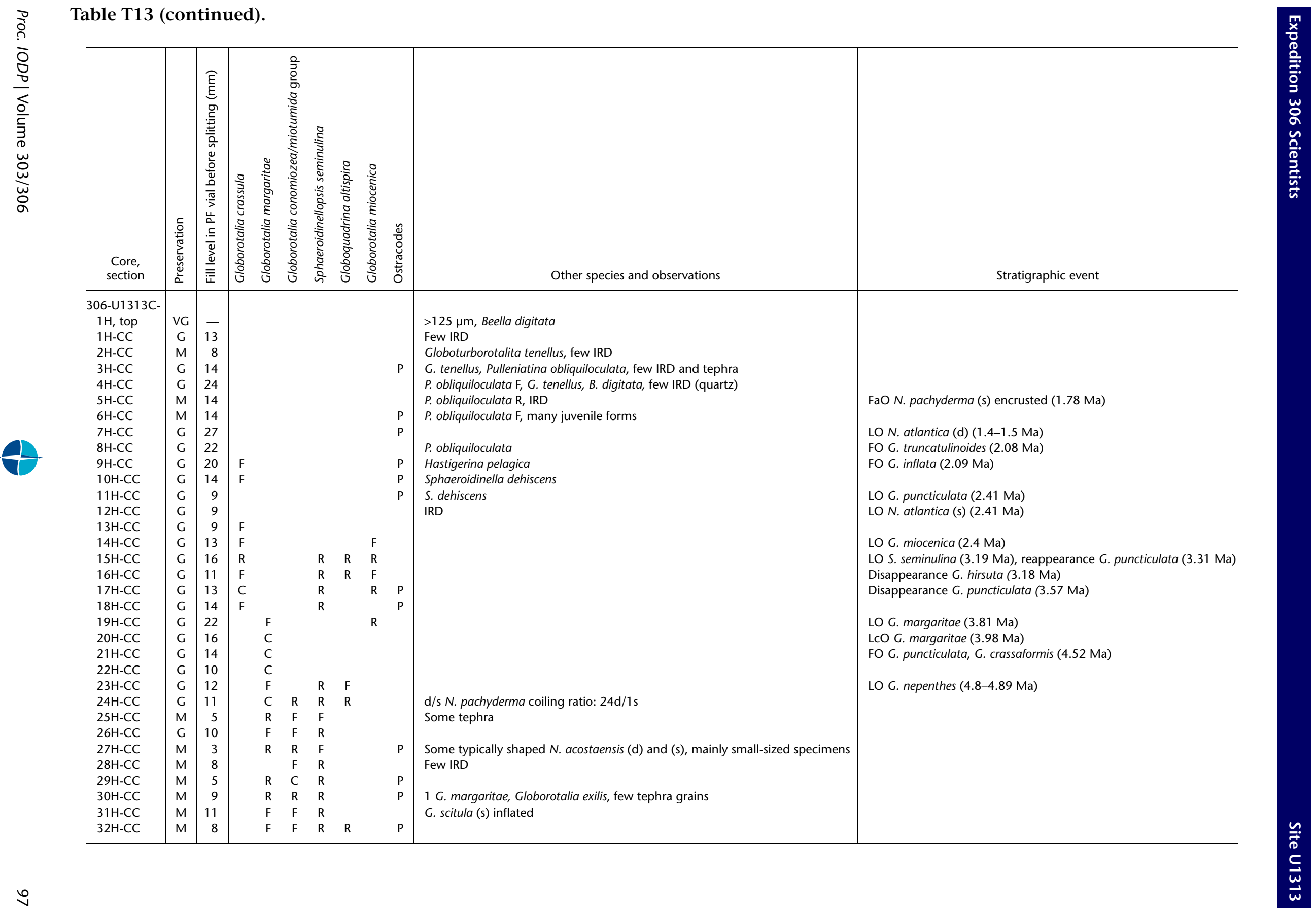
Table T14. Distribution of planktonic foraminifers, Hole U1313D. (Continued on next page.)

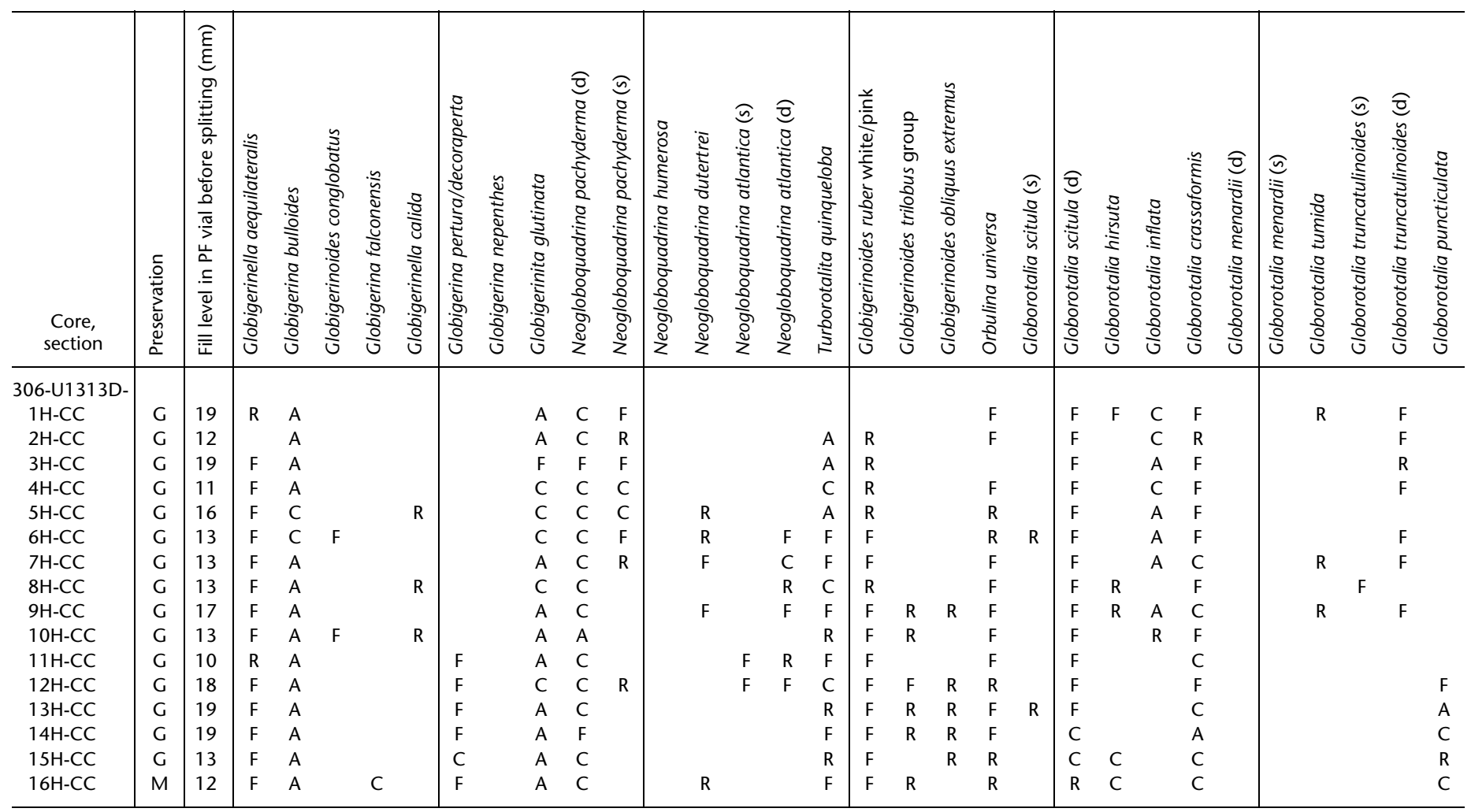

Notes: Abundance: $A=$ abundant, $C=$ common, $F=$ few, $R=$ rare. Preservation: $G=$ good, $M=$ moderate (see "Foraminifers" in the "Site U1312-U1315 methods" chapter). PF = planktonic foraminifers. $d=$ dextral, $s=$ sinistral. $P$ in ostracodes column = presence of valves. $I R D=$ ice-rafted debris, $F O=$ first occurrence, $F C O=$ first common occurrence, $L O=$ last occurrence. 


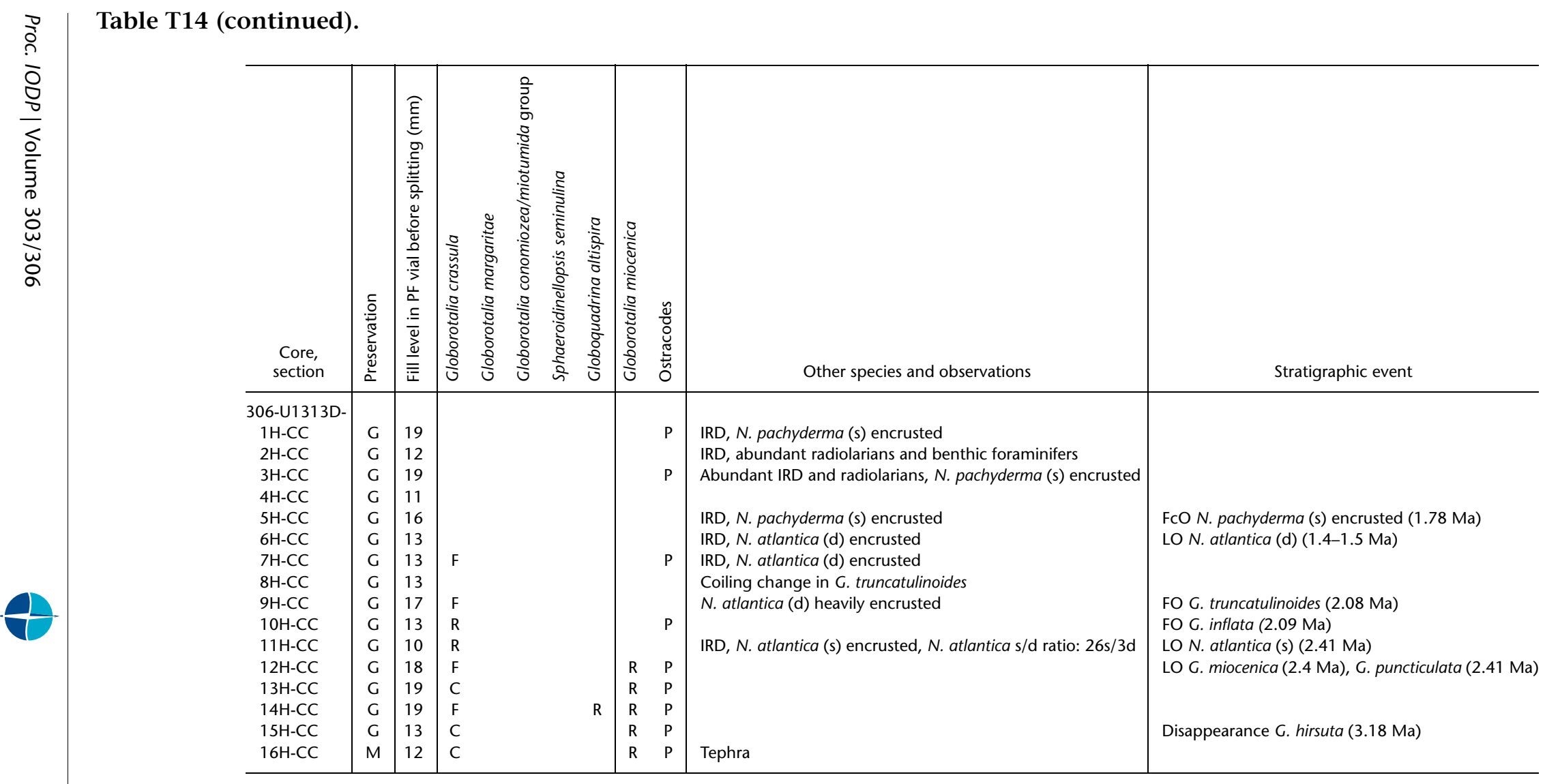


Table T15. Distribution of benthic foraminifers, Hole U1313A.

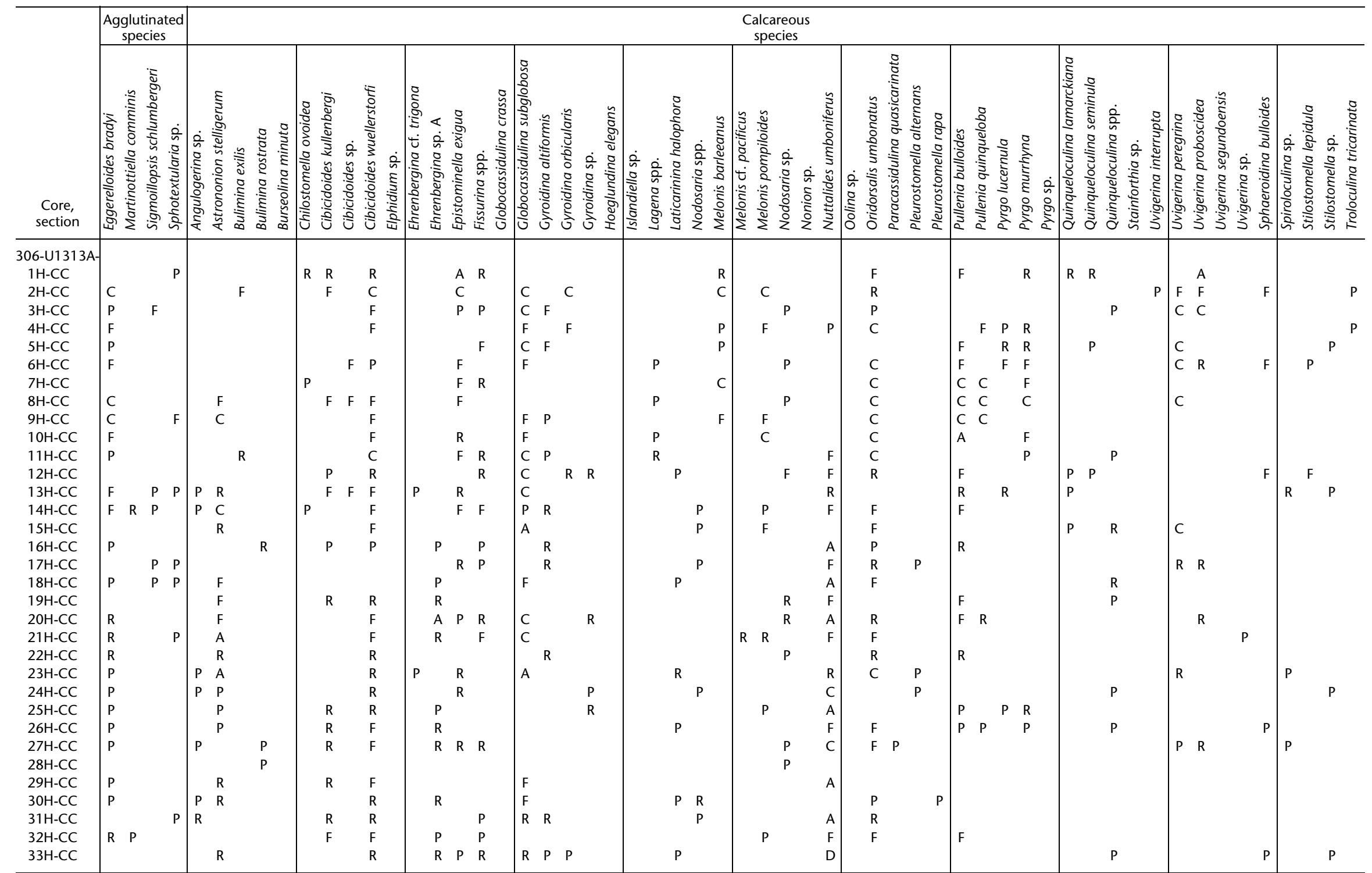

Notes: $\mathrm{A}=$ abundant, $\mathrm{C}=$ common, $\mathrm{F}=$ few, $\mathrm{R}=$ rare, $\mathrm{P}=$ present (see "Foraminifers" in the "Site U1312-U1315 methods" chapter). 


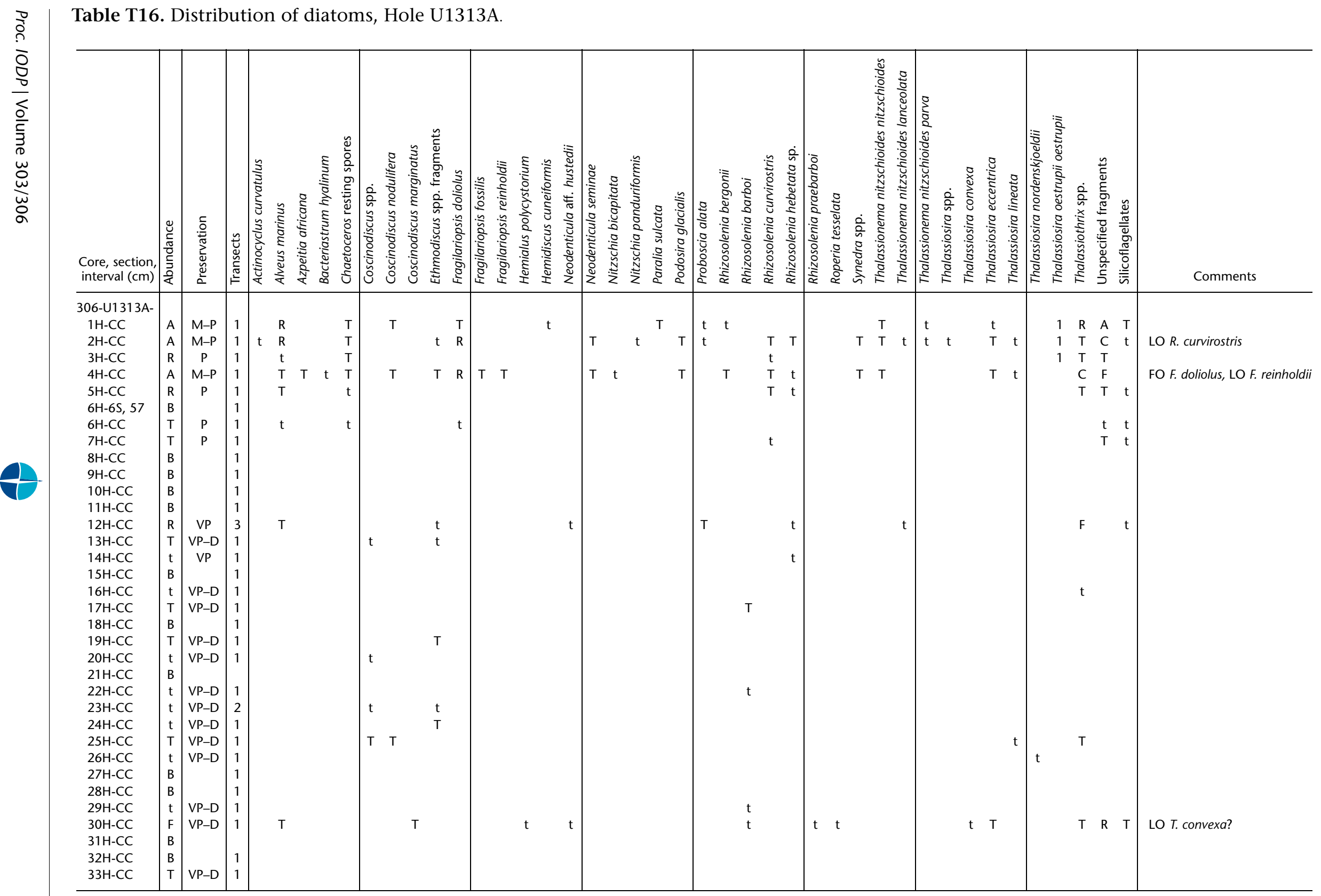

Notes: Abundance: $A=$ abundant,$C=$ common, $F=$ few, $R=$ rare, $T=$ trace, $t=$ single occurrence or fragment, $B=$ barren. Preservation: $M=M o d e r a t e, ~ P=$ poor, $V P=$ very poor, $D=$ dissolved. See "Diatoms" in the "Site U1312-U1315 methods" chapter. FO = first occurrence, LO = last occurrence.

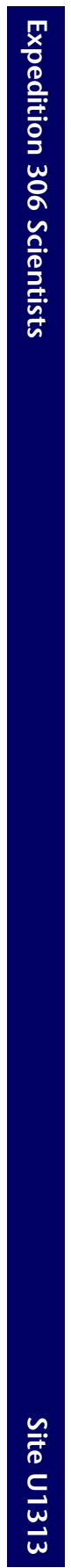




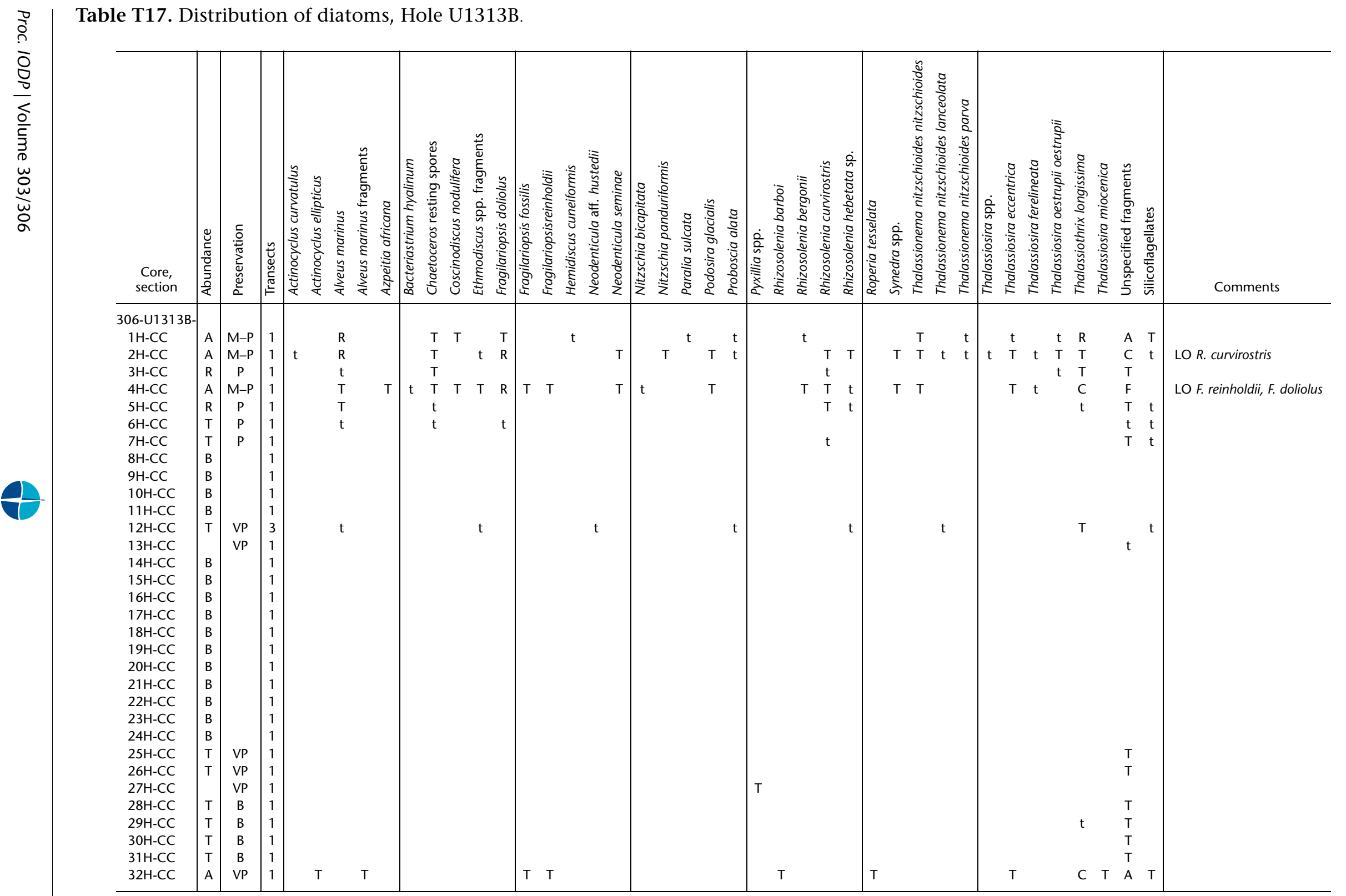

Notes: Abundance: $\mathrm{A}=$ abundant, $\mathrm{C}=$ common, $\mathrm{F}=$ few, $\mathrm{R}=$ rare, $\mathrm{T}=$ trace, $\mathrm{t}=$ single occurrence or fragment. $\mathrm{B}=$ barren. Preservation: $\mathrm{M}=\mathrm{Moderate}, \mathrm{P}=$ poor, $\mathrm{VP}=$ very poor. See "Diatoms" in the "Site U1312-U1315 methods" chapter. LO = last occurrence. 
Table T18. Distribution of diatoms, Hole U1313C. (Continued on next page.)

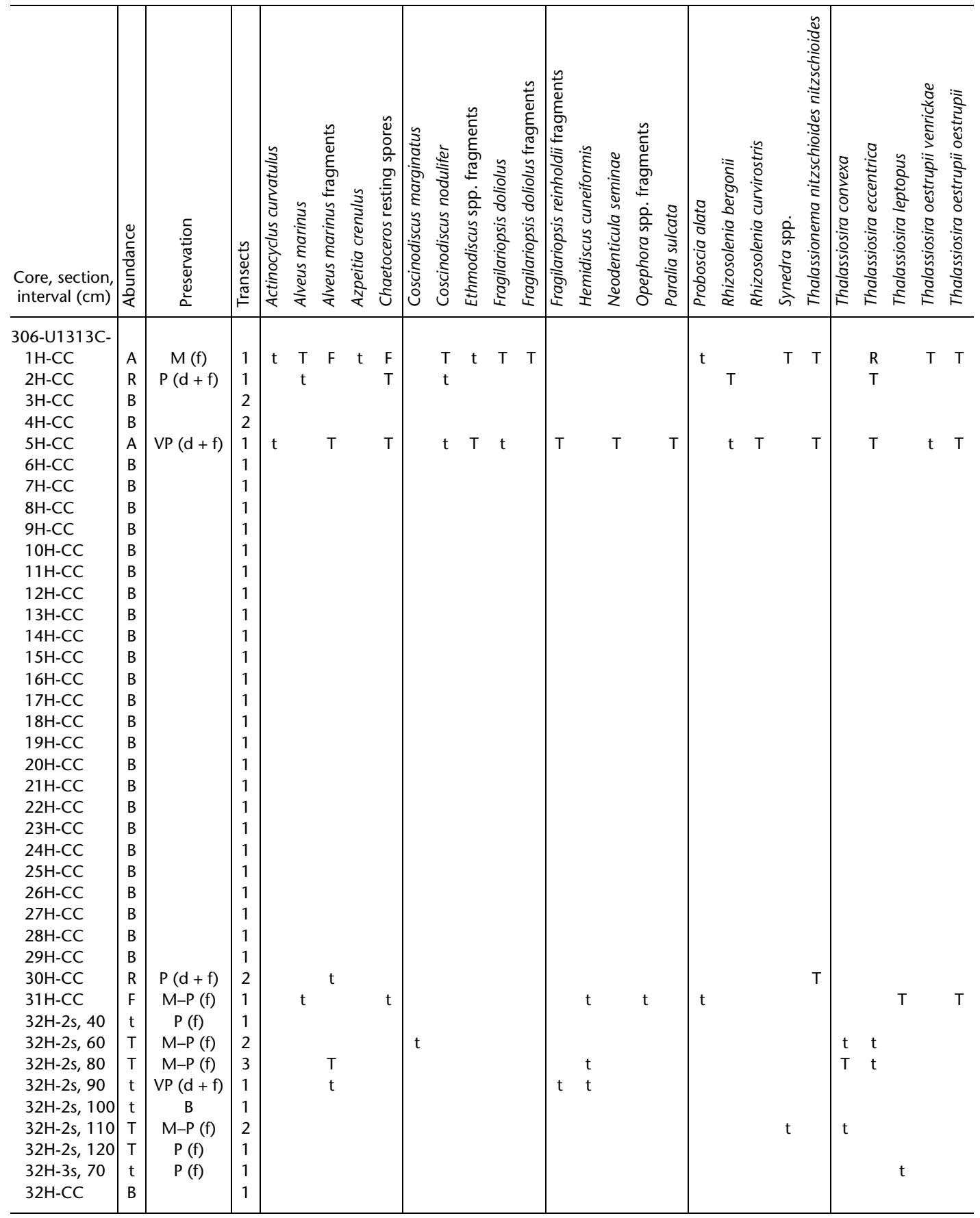

Notes: Abundance: $A=$ abundant, $C=$ common, $F=f e w, R=$ rare, $T=$ trace, $t=$ single occurrence or fragments, $B=$ barren. Preservation: $M=$ Moderate, $P=$ poor, $V P=$ very poor, $d=$ dissolved, $f=$ fragmented. See "Diatoms" in the "Site U1312-U1315 methods" chapter. FO = first occurrence, $\mathrm{LO}=$ last occurrence. 
Table T18 (continued).

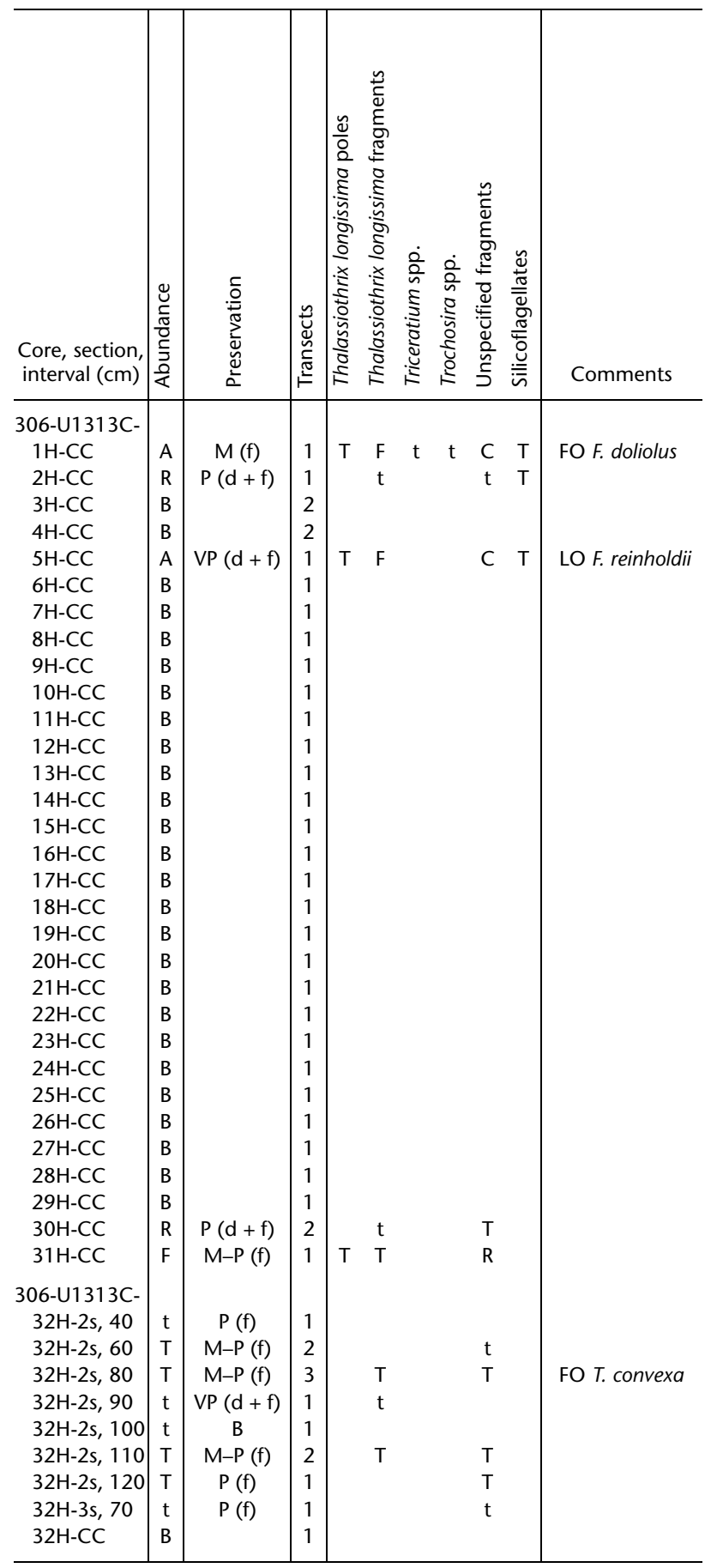




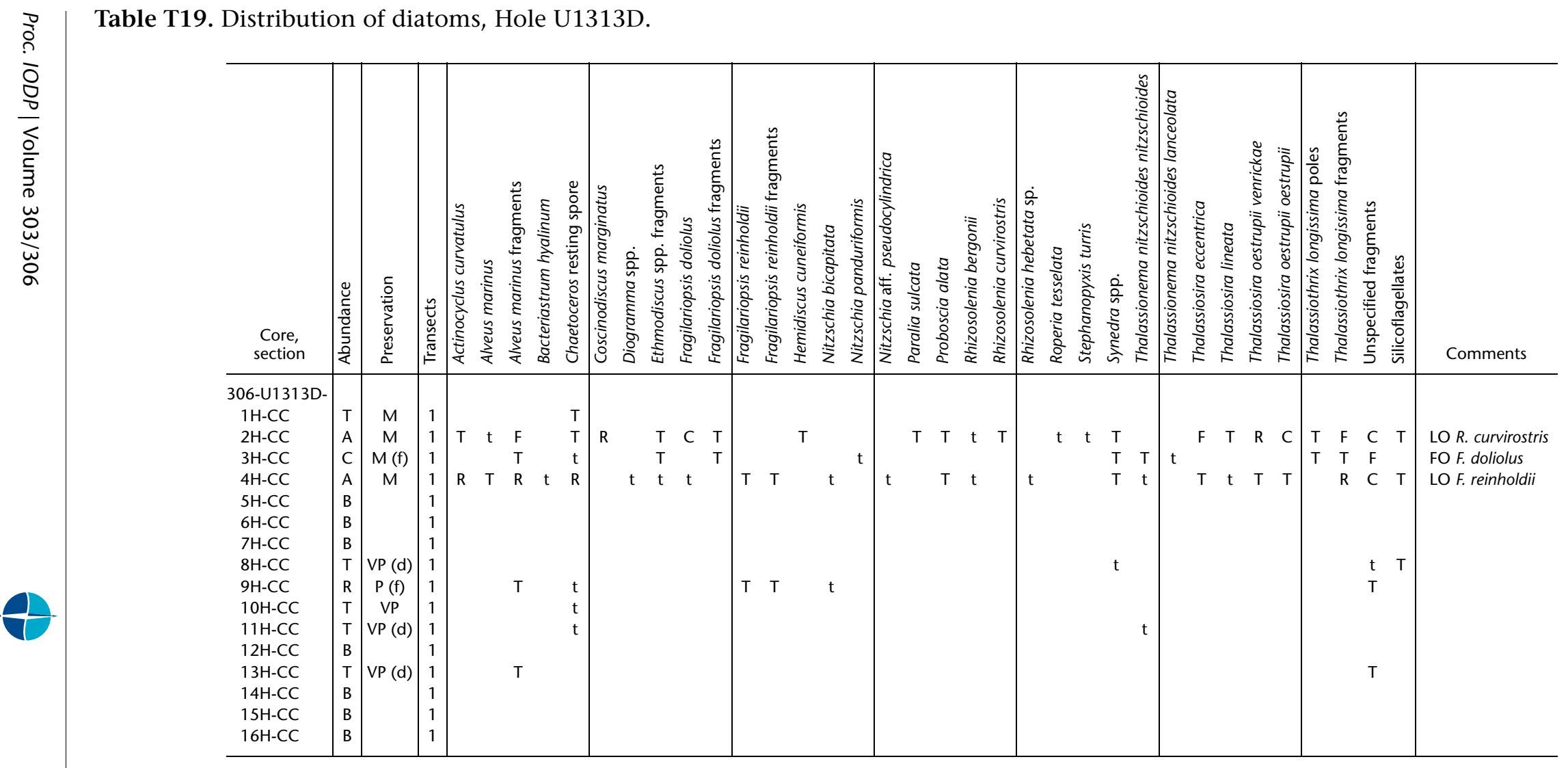

Notes: Abundance: $\mathrm{A}=$ abundant, $\mathrm{C}=$ common, $\mathrm{F}=$ few, $\mathrm{R}=$ rare, $\mathrm{T}=$ trace, $\mathrm{t}=$ single occurrence or fragment, $\mathrm{B}=$ barren. Preservation: $\mathrm{M}=\mathrm{Moderate}, \mathrm{P}=$ poor, $\mathrm{VP}=$ very poor, $\mathrm{d}=$ dissolved, $\mathrm{f}=$ fragmented. See "Diatoms" in the "Site U1312-U1315 methods" chapter. FO = first occurrence, LO = last occurrence. 


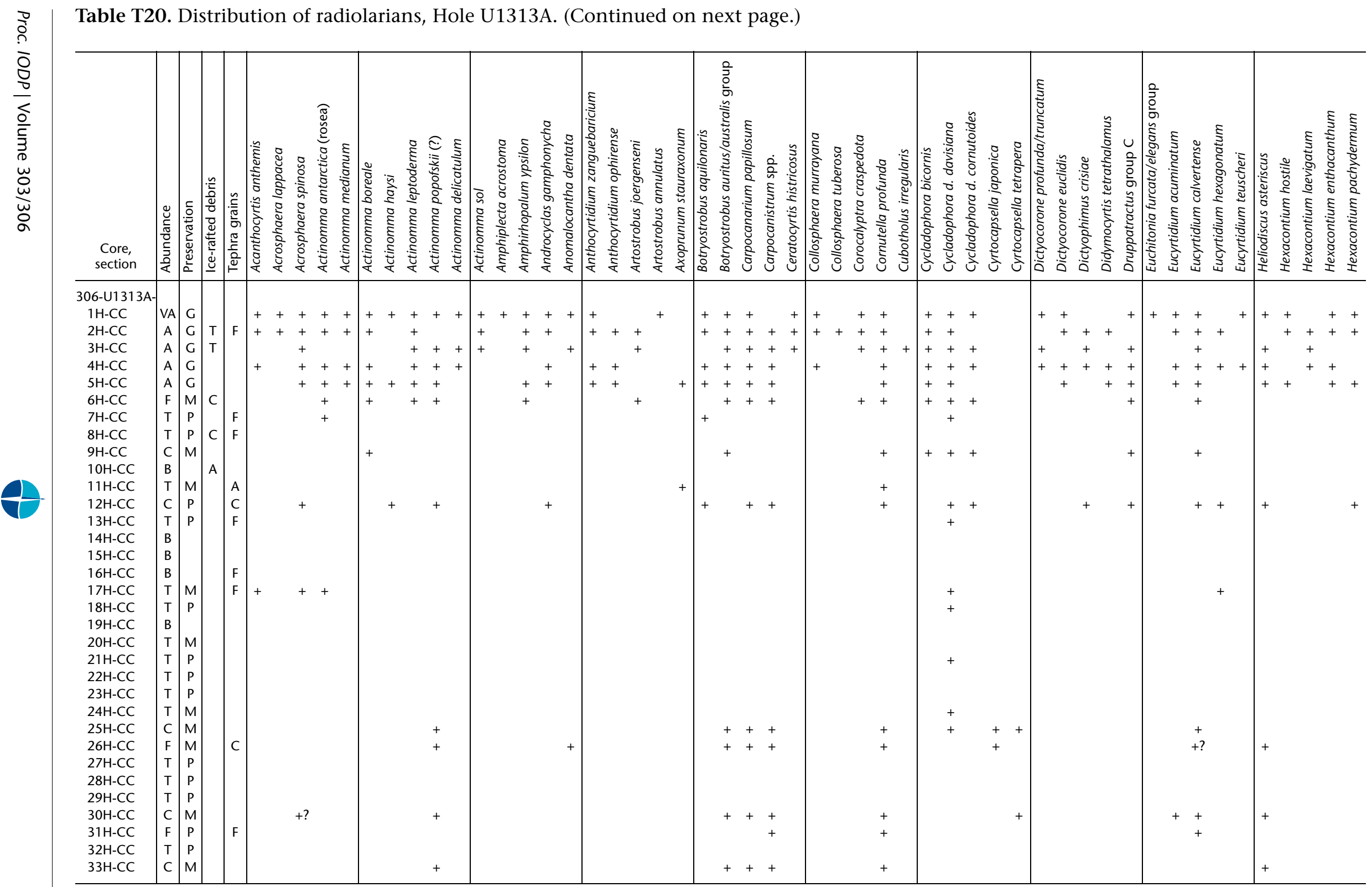

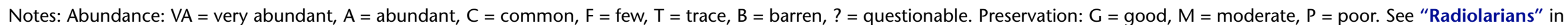
the "Site U1312-U1315 methods" chapter. 


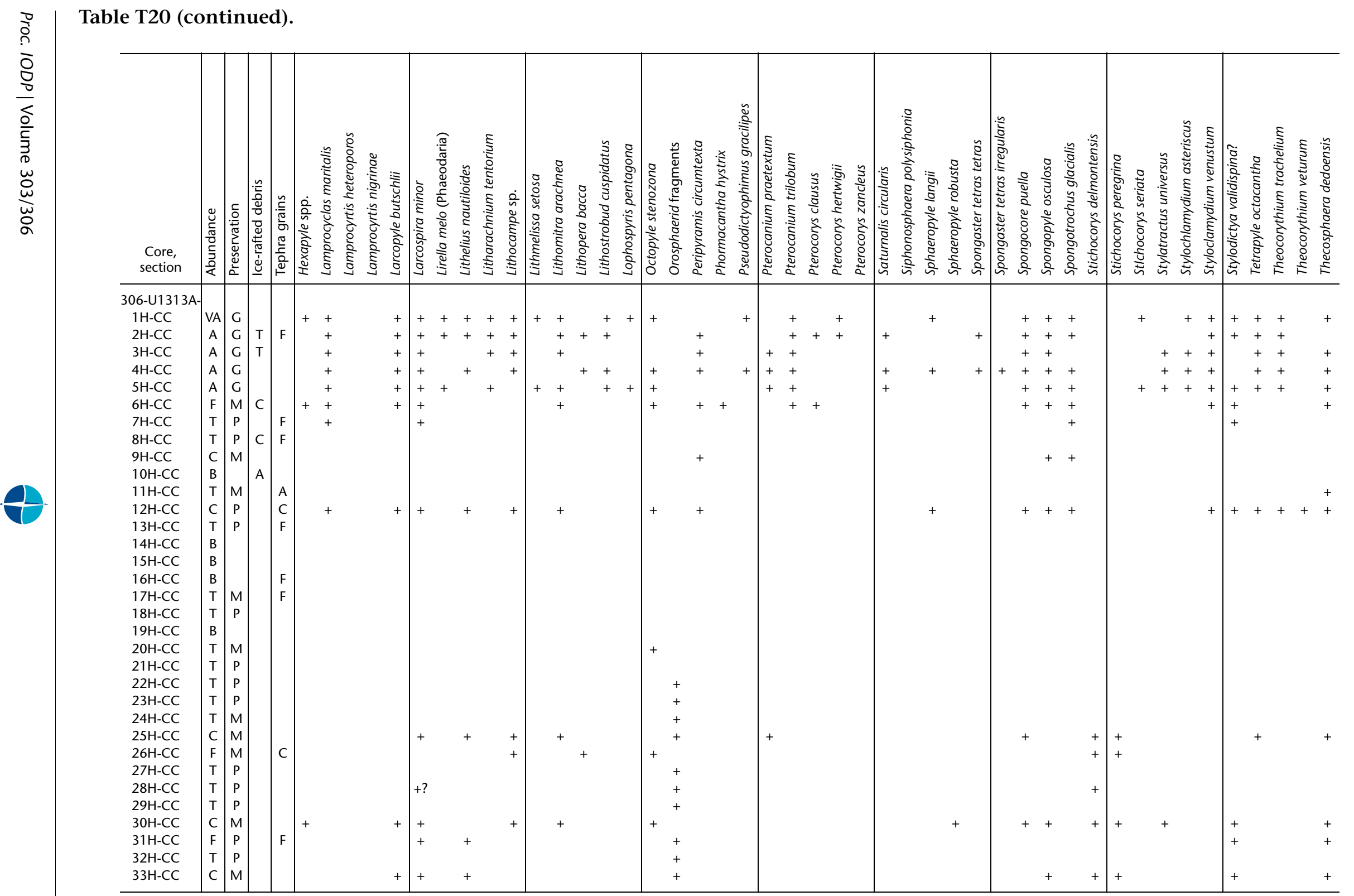



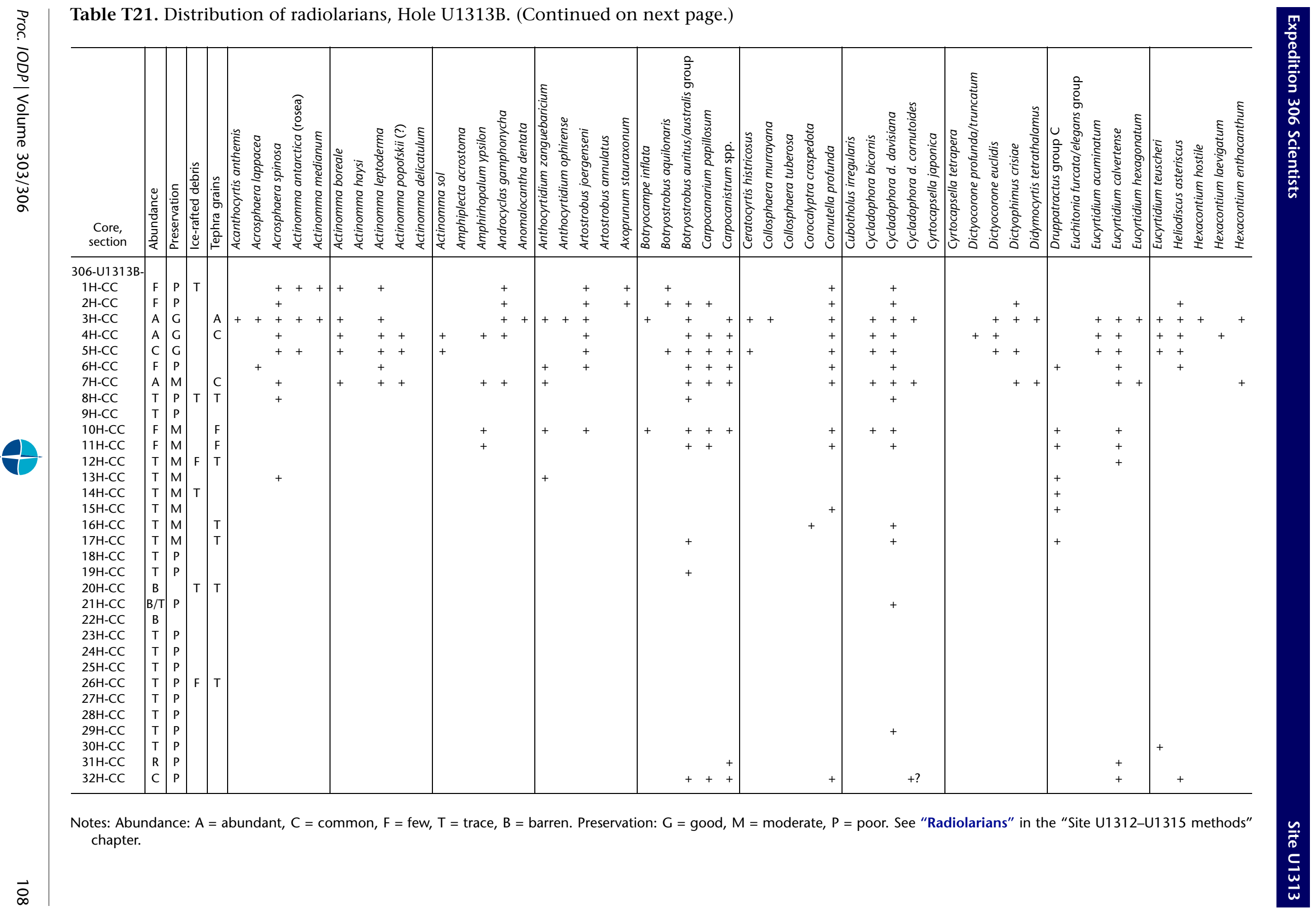

Notes: Abundance: $\mathrm{A}=$ abundant, $\mathrm{C}=$ common, $\mathrm{F}=$ few, $\mathrm{T}=$ trace, $\mathrm{B}=$ barren. Preservation: $\mathrm{G}=$ good, $\mathrm{M}=$ moderate, $\mathrm{P}=$ poor. See "Radiolarians" in the "Site U1312-U1315 methods" chapter. 


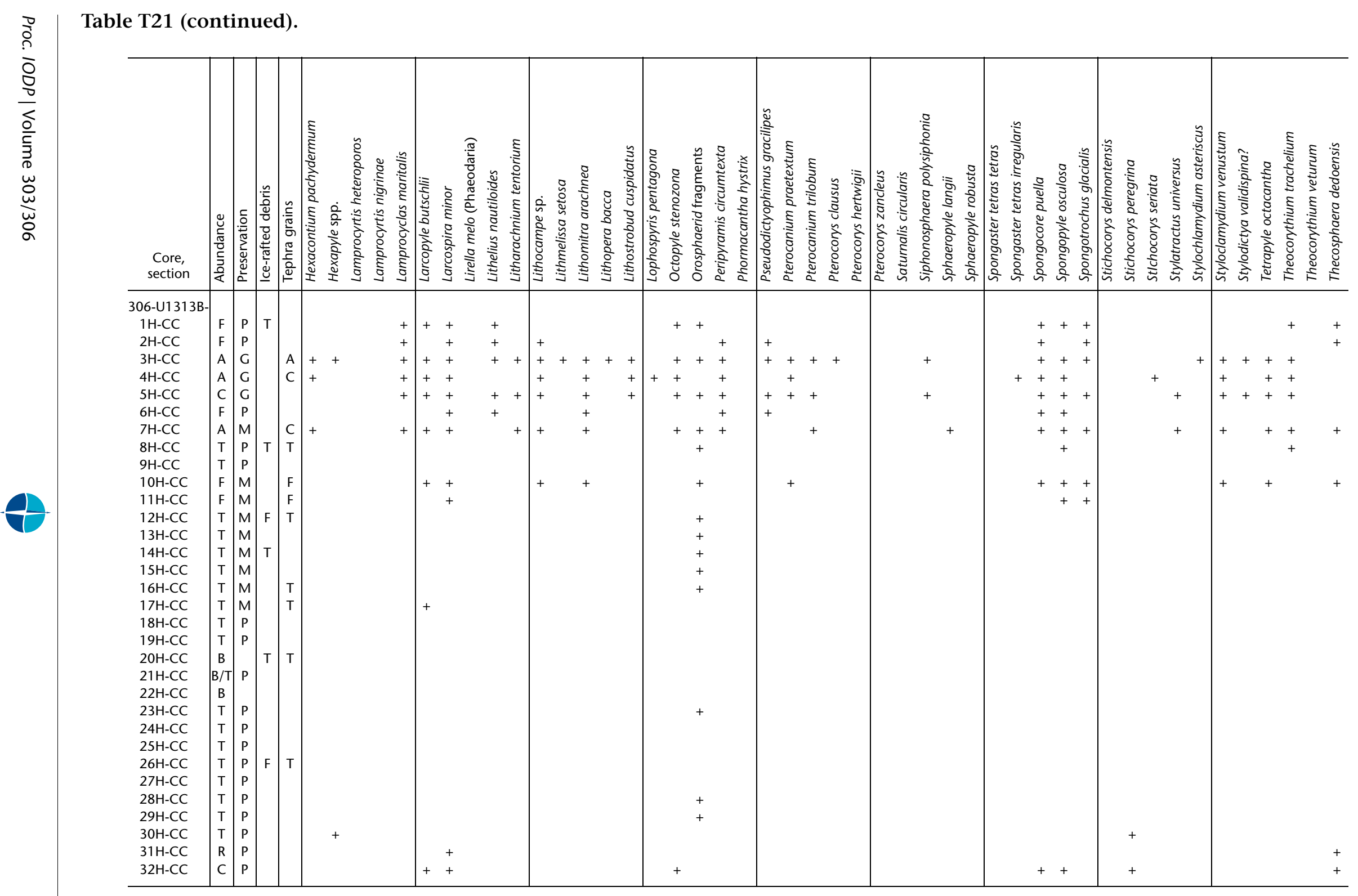




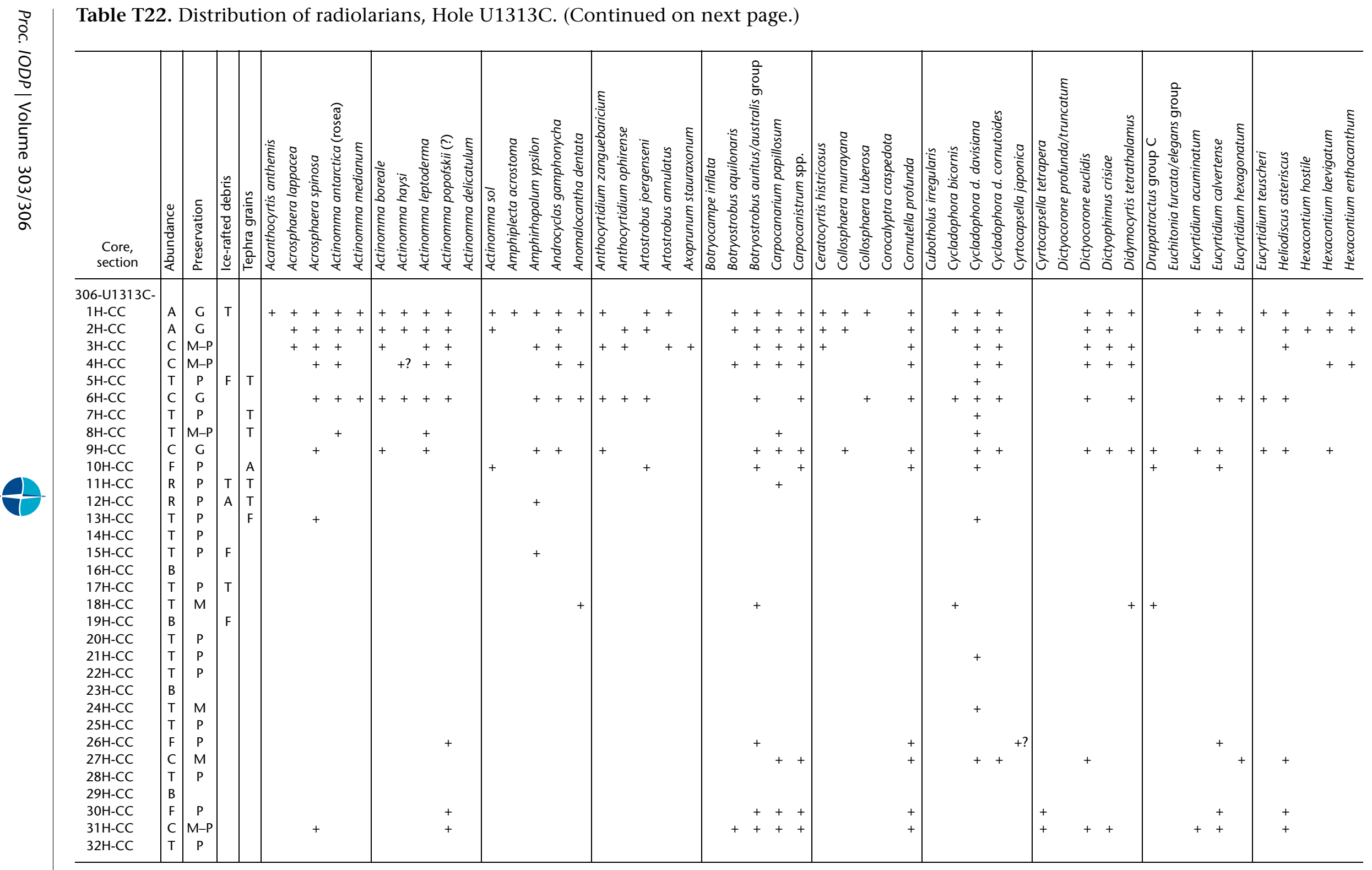

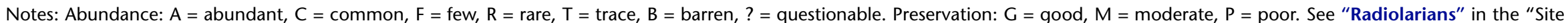
U1312-U1315 methods" chapter. 


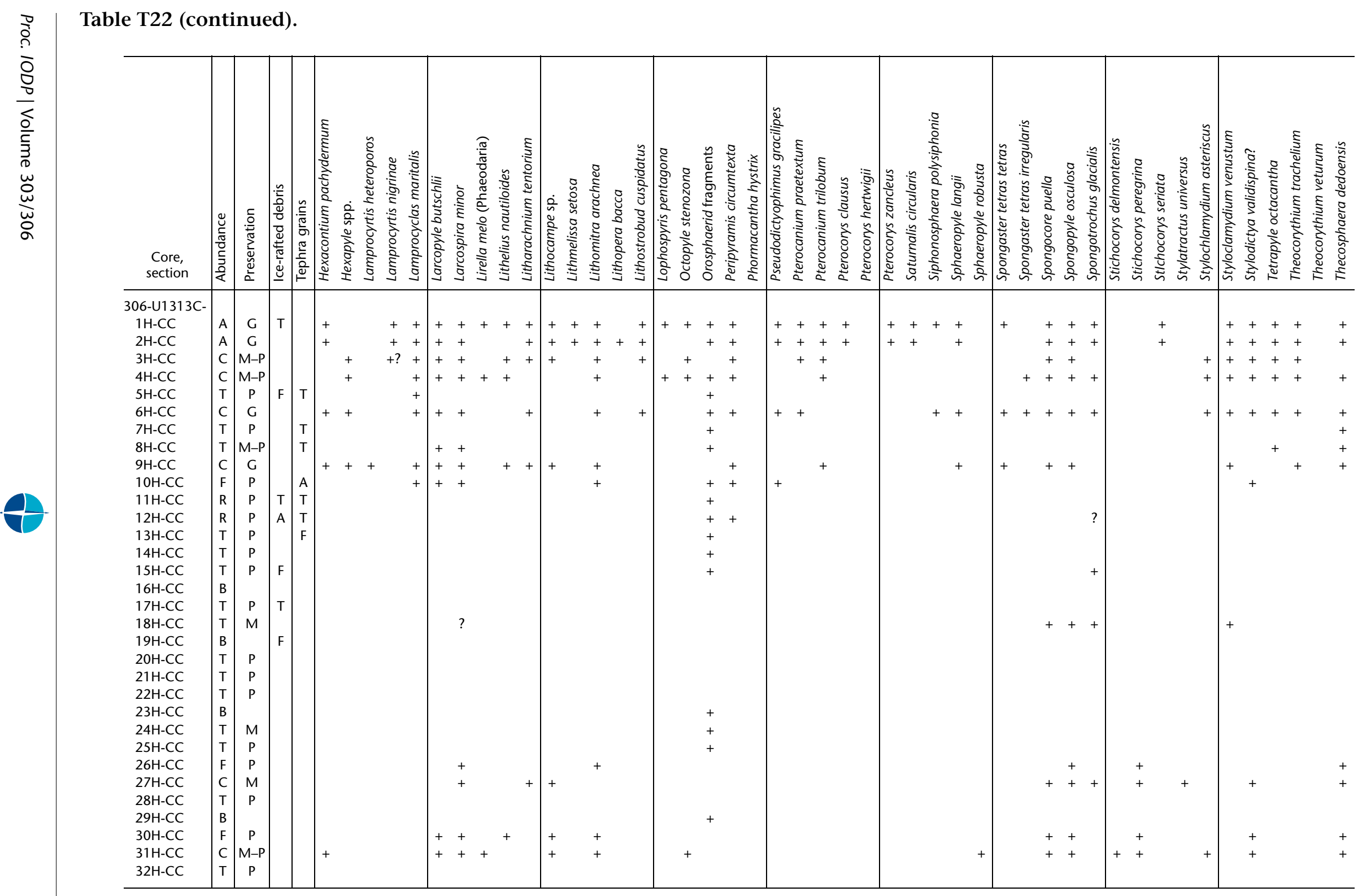



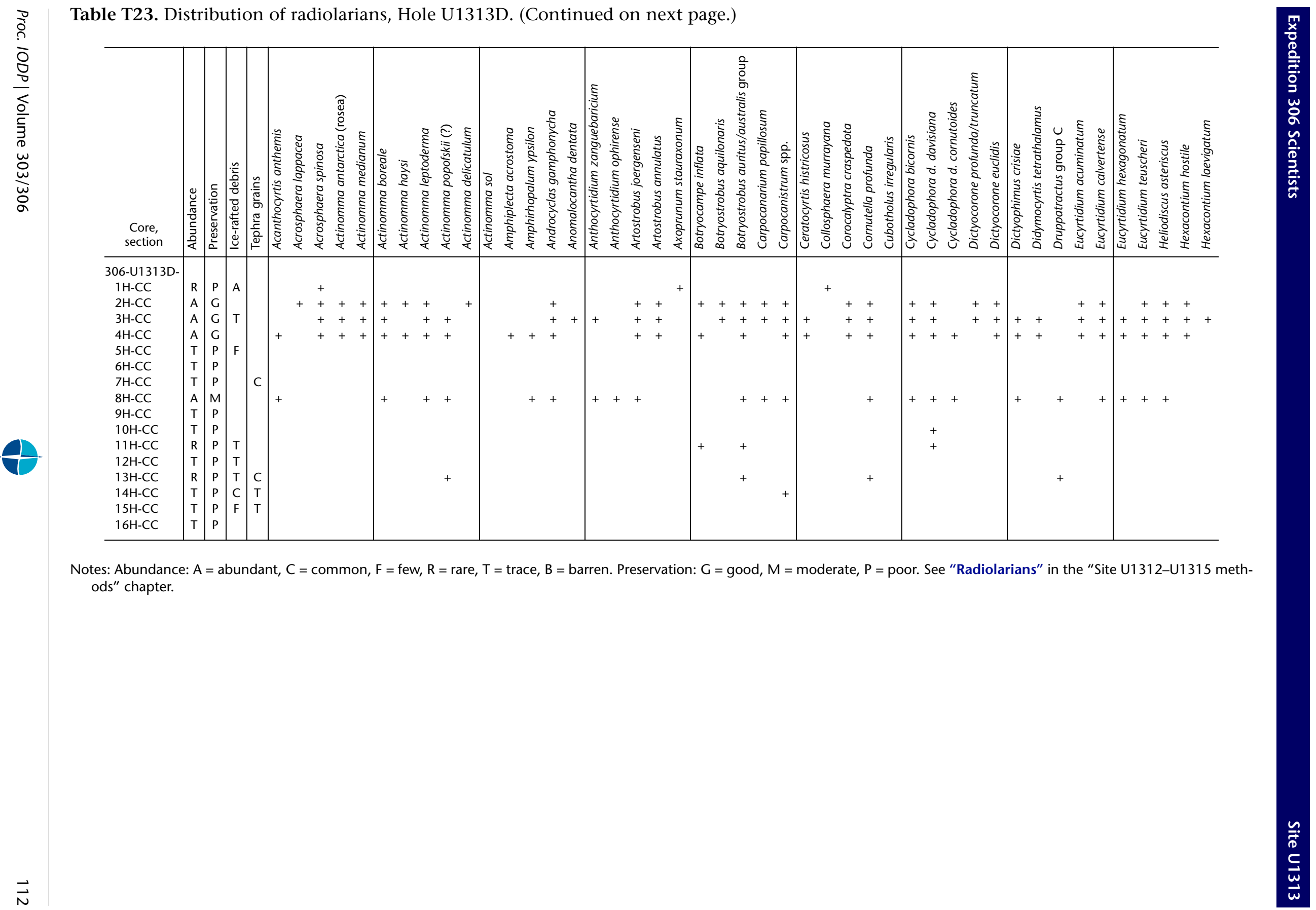

Notes: Abundance: $\mathrm{A}=$ abundant, $\mathrm{C}=$ common, $\mathrm{F}=$ few, $\mathrm{R}=$ rare, $\mathrm{T}=$ trace, $\mathrm{B}=$ barren. Preservation: $\mathrm{G}=$ good, $\mathrm{M}=$ moderate, $\mathrm{P}=$ poor. See "Radiolarians" in the "Site U1312-U1315 methods" chapter. 


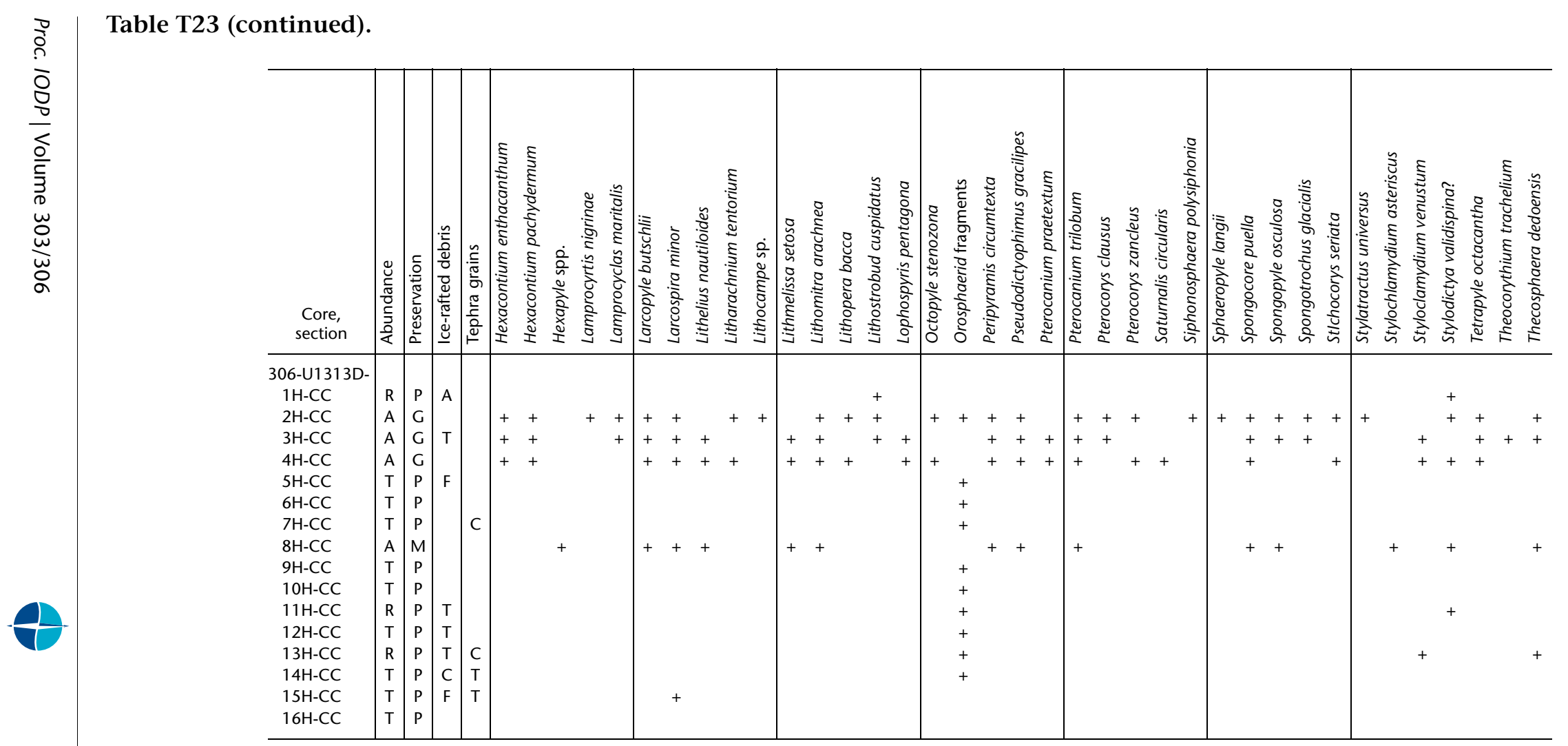


Table T24. Position of paleomagnetic transitions, Holes U1313A, U1313B, U1313C, and U1313D.

\begin{tabular}{|c|c|c|c|c|c|c|c|c|c|c|}
\hline \multirow[b]{2}{*}{$\begin{array}{l}\text { Polarity chron } \\
\text { interpretation }\end{array}$} & \multirow[b]{2}{*}{ Name } & \multirow[b]{2}{*}{$\begin{array}{l}\text { Age } \\
(\mathrm{Ma})\end{array}$} & \multicolumn{2}{|c|}{ Hole U1313A } & \multicolumn{2}{|c|}{ Hole U1313B } & \multicolumn{2}{|c|}{ Hole U1313C } & \multicolumn{2}{|c|}{ Hole U1313D } \\
\hline & & & $\begin{array}{l}\text { Depth } \\
\text { (mbsf) }\end{array}$ & $\begin{array}{l}\text { Relative } \\
\text { uncertainty } \\
(\mathrm{m})\end{array}$ & $\begin{array}{l}\text { Depth } \\
\text { (mbsf) }\end{array}$ & $\begin{array}{l}\text { Relative } \\
\text { uncertainty } \\
(\mathrm{m})\end{array}$ & $\begin{array}{l}\text { Depth } \\
\text { (mbsf) }\end{array}$ & $\begin{array}{l}\text { Relative } \\
\text { uncertainty } \\
(\mathrm{m})\end{array}$ & $\begin{array}{l}\text { Depth } \\
\text { (mbsf) }\end{array}$ & $\begin{array}{c}\text { Relative } \\
\text { uncertainty } \\
(\mathrm{m})\end{array}$ \\
\hline $\mathrm{C} 1 \mathrm{n}(\mathrm{b})$ & Brunhes/Matuyama & 0.78 & 34.2 & 0.4 & 34.1 & 0.4 & 34.1 & 0.4 & 33.8 & 0.1 \\
\hline $\mathrm{C} 1 \mathrm{r} .1 \mathrm{n}(\mathrm{t})$ & Jaramillo (t) & 0.99 & 42.1 & 0.1 & 41.0 & 0.1 & 42.0 & 0.1 & 41.2 & 0.1 \\
\hline C1r.1n (b) & Jaramillo (b) & 1.07 & 45.3 & 0.1 & 45.1 & 0.1 & 47.1 & 0.1 & 45.8 & 0.1 \\
\hline $\mathrm{C} 1 \mathrm{r} \cdot 2 \mathrm{r}-1 \mathrm{n}(\mathrm{t})$ & Cobb Mt. (t) & 1.19 & 49.5 & 0.1 & 49.4 & 0.1 & & & 49.6 & 0.1 \\
\hline $\mathrm{C} 1 \mathrm{r} \cdot 2 \mathrm{r}-1 \mathrm{n}(\mathrm{b})$ & Cobb Mt. (b) & 1.215 & 50.7 & 0.1 & 50.8 & 0.1 & & & 50.9 & 0.1 \\
\hline$C 2 n(t)$ & Olduvai (t) & 1.77 & 73.7 & 0.1 & 72.7 & 0.1 & 75.2 & 0.2 & 75.5 & 0.2 \\
\hline$C 2 n(b)$ & Olduvai (b) & 1.95 & 82.2 & 0.1 & 81.8 & 0.1 & 82.4 & 0.4 & 83.1 & 0.1 \\
\hline$C 2 r .1 n(t)$ & Reunion $(t)$ & 2.115 & 89.1 & 0.1 & & & 89.0 & 0.3 & & \\
\hline C2r.1n (b) & Reunion (b) & 2.153 & 90.6 & 0.1 & & & 90.0 & 0.1 & & \\
\hline C2An.1n (t) & Matuyama/Gauss & 2.581 & 111.0 & 0.2 & 109.9 & 0.2 & 110.5 & 0.1 & 111.6 & 0.1 \\
\hline C2An.1n (b) & Kaena (t) & 3.04 & 130.2 & 0.2 & & & 128.6 & 0.1 & 130.3 & 0.3 \\
\hline C2An.2n (t) & Kaena (b) & 3.11 & 131.7 & 0.2 & & & 131.7 & 0.1 & 131.9 & 0.1 \\
\hline C2An.2n (b) & Mammoth (t) & 3.22 & 136.2 & 0.2 & 135.9 & 0.1 & 137.4 & 0.4 & 135.9 & 0.3 \\
\hline C2An.3n (t) & Mammoth (b) & 3.33 & 138.4 & 0.1 & 139.1 & 0.2 & 138.4 & 0.1 & 139.0 & 0.2 \\
\hline C2An.3n (b) & Gauss/Gilbert & 3.58 & 155.2 & 0.2 & 154.8 & 0.1 & 153.8 & 0.1 & & \\
\hline C3n.1n (t) & Cochiti (t) & 4.18 & 175.4 & 0.6 & 176.1 & 1.1 & 175.5 & 0.2 & & \\
\hline C3n.1n (b) & Cochiti (b) & 4.29 & 182.1 & 0.4 & 180.7 & 0.9 & 183.0 & 0.1 & & \\
\hline$C 3 n \cdot 2 n(t)$ & Nunivak $(\mathrm{t})$ & 4.48 & 188.4 & 0.1 & 187.5 & 1.2 & 188.9 & 0.1 & & \\
\hline C3n.2n (b) & Nunivak (b) & 4.62 & 195.6 & 0.3 & 194.1 & 0.1 & 195.1 & 0.2 & & \\
\hline C3n.3n (t) & Sidufjall $(\mathrm{t})$ & 4.80 & 202.0 & 0.1 & 201.5 & 0.1 & 202.6 & 0.2 & & \\
\hline C3n.3n (b) & Sidufjall (b) & 4.89 & 204.3 & 0.7 & 206.7 & 0.1 & 207.0 & 0.1 & & \\
\hline$C 3 n \cdot 4 n(t)$ & Thvera $(\mathrm{t})$ & 4.98 & 210.6 & 0.4 & 210.8 & 0.1 & 212.1 & 0.1 & & \\
\hline C3n.4n (b) & Thvera (b) & 5.230 & 222.3 & 0.3 & 220.8 & 0.3 & 222.7 & 0.2 & & \\
\hline C3An.1n (t) & Gilbert (b) & 5.894 & 239.2 & 1.0 & 239.4 & 1.3 & 244.2 & 0.8 & & \\
\hline C3An.1n (b) & & 6.137 & 249.7 & 0.3 & 252.3 & 0.3 & 253.0 & 0.4 & & \\
\hline C3An.2n (t) & & 6.269 & & & & & & & & \\
\hline C $3 A n .2 n(b)$ & & 6.567 & & & & & & & & \\
\hline
\end{tabular}

Notes: Interpretations in italics correspond to uncertain ties to the reference geomagnetic polarity timescale. $t=$ top, $b=b o t t o m$. 
Table T25. Shipboard composite depths, Holes U1313A, U1313B, U1313C, and U1313D.

\begin{tabular}{|c|c|c|c|}
\hline \multirow[b]{2}{*}{ Core } & \multicolumn{2}{|c|}{ Top depth } & \multirow{2}{*}{$\begin{array}{l}\text { Offset } \\
(\mathrm{m})\end{array}$} \\
\hline & (mbsf) & $(\mathrm{mcd})$ & \\
\hline \multicolumn{4}{|c|}{ 306-U1313A- } \\
\hline $1 \mathrm{H}$ & 0.0 & 0.00 & 0.00 \\
\hline $2 \mathrm{H}$ & 5.2 & 5.81 & 0.61 \\
\hline $3 \mathrm{H}$ & 14.7 & 16.24 & 1.54 \\
\hline $4 \mathrm{H}$ & 24.2 & 27.95 & 3.75 \\
\hline $5 \mathrm{H}$ & 33.7 & 38.45 & 4.75 \\
\hline $6 \mathrm{H}$ & 43.2 & 49.42 & 6.22 \\
\hline $7 \mathrm{H}$ & 52.7 & 60.59 & 7.89 \\
\hline $8 \mathrm{H}$ & 62.2 & 71.03 & 8.83 \\
\hline $9 \mathrm{H}$ & 71.7 & 81.13 & 9.43 \\
\hline $10 \mathrm{H}$ & 81.2 & 91.91 & 10.71 \\
\hline $11 \mathrm{H}$ & 90.7 & 102.66 & 11.96 \\
\hline $12 \mathrm{H}$ & 100.2 & 113.04 & 12.84 \\
\hline $13 \mathrm{H}$ & 109.7 & 122.45 & 12.75 \\
\hline $14 \mathrm{H}$ & 119.2 & 133.06 & 13.86 \\
\hline $15 \mathrm{H}$ & 128.7 & 143.36 & 14.66 \\
\hline $16 \mathrm{H}$ & 138.2 & 153.43 & 15.23 \\
\hline $17 \mathrm{H}$ & 147.7 & 164.31 & 16.61 \\
\hline $18 \mathrm{H}$ & 157.2 & 175.41 & 18.21 \\
\hline $19 \mathrm{H}$ & 166.7 & 185.69 & 18.99 \\
\hline $20 \mathrm{H}$ & 176.2 & 196.71 & 20.51 \\
\hline $21 \mathrm{H}$ & 185.7 & 206.41 & 20.71 \\
\hline $22 \mathrm{H}$ & 195.2 & 217.22 & 22.02 \\
\hline $23 \mathrm{H}$ & 204.7 & 228.19 & 23.49 \\
\hline $24 \mathrm{H}$ & 214.2 & 237.59 & 23.39 \\
\hline $25 \mathrm{H}$ & 223.7 & 246.94 & 23.24 \\
\hline $26 \mathrm{H}$ & 233.2 & 256.44 & 23.24 \\
\hline $27 \mathrm{H}$ & 242.7 & 270.13 & 27.43 \\
\hline $28 \mathrm{H}$ & 252.2 & 279.58 & 27.38 \\
\hline $29 \mathrm{H}$ & 261.7 & 290.03 & 28.33 \\
\hline $30 \mathrm{H}$ & 271.2 & 300.75 & 29.55 \\
\hline $31 \mathrm{H}$ & 280.7 & 310.25 & 29.55 \\
\hline $32 \mathrm{H}$ & 290.2 & 319.75 & 29.55 \\
\hline $33 \mathrm{H}$ & 299.7 & 329.25 & 29.55 \\
\hline \multicolumn{4}{|c|}{ 306-U1313B- } \\
\hline $1 \mathrm{H}$ & 0.0 & 0.17 & 0.17 \\
\hline $2 \mathrm{H}$ & 5.9 & 7.66 & 1.76 \\
\hline $3 \mathrm{H}$ & 15.4 & 18.10 & 2.70 \\
\hline $4 \mathrm{H}$ & 24.9 & 29.45 & 4.55 \\
\hline $5 \mathrm{H}$ & 34.4 & 40.60 & 6.20 \\
\hline $6 \mathrm{H}$ & 43.9 & 50.25 & 6.35 \\
\hline $7 \mathrm{H}$ & 53.4 & 61.29 & 7.89 \\
\hline $8 \mathrm{H}$ & 62.9 & 72.53 & 9.63 \\
\hline $9 \mathrm{H}$ & 72.4 & 82.47 & 10.07 \\
\hline $10 \mathrm{H}$ & 81.9 & 93.21 & 11.31 \\
\hline $11 \mathrm{H}$ & 91.4 & 103.07 & 11.67 \\
\hline $12 \mathrm{H}$ & 100.9 & 113.94 & 13.04 \\
\hline $13 \mathrm{H}$ & 110.4 & 124.01 & 13.61 \\
\hline $14 \mathrm{H}$ & 119.9 & 134.48 & 14.58 \\
\hline $15 \mathrm{H}$ & 129.4 & 144.28 & 14.88 \\
\hline $16 \mathrm{H}$ & 138.9 & 155.08 & 16.18 \\
\hline $17 \mathrm{H}$ & 148.4 & 165.61 & 17.21 \\
\hline $18 \mathrm{H}$ & 157.9 & 176.16 & 18.26 \\
\hline $19 \mathrm{H}$ & 167.4 & 187.11 & 19.71 \\
\hline $20 \mathrm{H}$ & 176.9 & 197.61 & 20.71 \\
\hline $21 \mathrm{H}$ & 188.4 & 210.74 & 22.34 \\
\hline $22 \mathrm{H}$ & 197.9 & 220.29 & 22.39 \\
\hline $23 \mathrm{H}$ & 207.4 & 230.94 & 23.54 \\
\hline $24 \mathrm{H}$ & 216.9 & 241.93 & 25.03 \\
\hline
\end{tabular}

\begin{tabular}{|c|c|c|c|}
\hline \multirow[b]{2}{*}{ Core } & \multicolumn{2}{|c|}{ Top depth } & \multirow{2}{*}{$\begin{array}{l}\text { Offse } \\
(\mathrm{m})\end{array}$} \\
\hline & (mbsf) & (mcd) & \\
\hline $25 \mathrm{H}$ & 226.4 & 252.02 & 25.62 \\
\hline $26 \mathrm{H}$ & 235.9 & 261.41 & 25.51 \\
\hline $27 \mathrm{H}$ & 245.4 & 270.43 & 25.03 \\
\hline $28 \mathrm{H}$ & 254.9 & 282.43 & 27.53 \\
\hline $29 \mathrm{H}$ & 264.4 & 291.93 & 27.53 \\
\hline $30 \mathrm{H}$ & 273.9 & 301.43 & 27.53 \\
\hline $31 \mathrm{H}$ & 283.4 & 310.59 & 27.19 \\
\hline $32 \mathrm{H}$ & 292.9 & 320.09 & 27.19 \\
\hline \multicolumn{4}{|c|}{ 306-U1313C- } \\
\hline $1 \mathrm{H}$ & 0.0 & 0.00 & 0.00 \\
\hline $2 \mathrm{H}$ & 2.7 & 3.13 & 0.43 \\
\hline $3 \mathrm{H}$ & 12.2 & 13.64 & 1.44 \\
\hline $4 \mathrm{H}$ & 21.7 & 24.50 & 2.80 \\
\hline $5 \mathrm{H}$ & 31.2 & 35.74 & 4.54 \\
\hline $6 \mathrm{H}$ & 40.7 & 45.44 & 4.74 \\
\hline $7 \mathrm{H}$ & 50.2 & 57.03 & 6.83 \\
\hline $8 \mathrm{H}$ & 59.7 & 68.03 & 8.33 \\
\hline $9 \mathrm{H}$ & 69.2 & 77.13 & 7.93 \\
\hline $10 \mathrm{H}$ & 78.7 & 88.71 & 10.01 \\
\hline $11 \mathrm{H}$ & 88.2 & 99.11 & 10.91 \\
\hline $12 \mathrm{H}$ & 97.7 & 110.00 & 12.30 \\
\hline $13 \mathrm{H}$ & 107.2 & 119.80 & 12.60 \\
\hline $14 \mathrm{H}$ & 116.7 & 130.56 & 13.86 \\
\hline $15 \mathrm{H}$ & 126.2 & 140.66 & 14.46 \\
\hline $16 \mathrm{H}$ & 135.7 & 150.98 & 15.28 \\
\hline $17 \mathrm{H}$ & 145.2 & 161.66 & 16.46 \\
\hline $18 \mathrm{H}$ & 154.7 & 172.31 & 17.61 \\
\hline $19 \mathrm{H}$ & 164.2 & 182.73 & 18.53 \\
\hline $20 \mathrm{H}$ & 173.7 & 193.61 & 19.91 \\
\hline $21 \mathrm{H}$ & 183.2 & 203.51 & 20.31 \\
\hline $22 \mathrm{H}$ & 192.7 & 213.94 & 21.24 \\
\hline $23 \mathrm{H}$ & 202.2 & 224.24 & 22.04 \\
\hline $24 \mathrm{H}$ & 211.7 & 233.94 & 22.24 \\
\hline $25 \mathrm{H}$ & 221.2 & 244.44 & 23.24 \\
\hline $26 \mathrm{H}$ & 230.7 & 253.94 & 23.24 \\
\hline $27 \mathrm{H}$ & 240.2 & 263.44 & 23.24 \\
\hline $28 \mathrm{H}$ & 249.7 & 273.78 & 24.08 \\
\hline $29 \mathrm{H}$ & 259.2 & 283.28 & 24.08 \\
\hline $30 \mathrm{H}$ & 268.7 & 295.31 & 26.61 \\
\hline $31 \mathrm{H}$ & 278.2 & 305.41 & 27.21 \\
\hline $32 \mathrm{H}$ & 286.9 & 314.11 & 27.21 \\
\hline \multicolumn{4}{|c|}{ 306-U1313D- } \\
\hline $1 \mathrm{H}$ & 0.0 & 1.02 & 1.02 \\
\hline $2 \mathrm{H}$ & 9.5 & 10.68 & 1.18 \\
\hline $3 \mathrm{H}$ & 19.0 & 21.60 & 2.60 \\
\hline $4 \mathrm{H}$ & 28.5 & 32.90 & 4.40 \\
\hline $5 \mathrm{H}$ & 38.0 & 43.75 & 5.75 \\
\hline $6 \mathrm{H}$ & 47.5 & 53.77 & 6.27 \\
\hline $7 \mathrm{H}$ & 57.0 & 64.91 & 7.91 \\
\hline $8 \mathrm{H}$ & 66.5 & 74.08 & 7.58 \\
\hline $9 \mathrm{H}$ & 76.0 & 84.73 & 8.73 \\
\hline $10 \mathrm{H}$ & 85.5 & 95.54 & 10.04 \\
\hline $11 \mathrm{H}$ & 95.0 & 105.72 & 10.72 \\
\hline $12 \mathrm{H}$ & 104.5 & 115.96 & 11.46 \\
\hline $13 \mathrm{H}$ & 114.0 & 126.71 & 12.71 \\
\hline $14 \mathrm{H}$ & 123.5 & 137.51 & 14.01 \\
\hline $15 \mathrm{H}$ & 133.0 & 148.19 & 15.19 \\
\hline $16 \mathrm{H}$ & 142.5 & 159.12 & 16.62 \\
\hline
\end{tabular}


Table T26. Primary splice tie points, Site U1313.

\begin{tabular}{|c|c|c|c|c|c|c|}
\hline \multirow{2}{*}{$\begin{array}{l}\text { Core, section, } \\
\text { interval }(\mathrm{cm})\end{array}$} & \multicolumn{2}{|c|}{ Depth } & & \multirow{2}{*}{$\begin{array}{l}\text { Core, section, } \\
\text { interval }(\mathrm{cm})\end{array}$} & \multicolumn{2}{|c|}{ Depth } \\
\hline & (mbsf) & $(\mathrm{mcd})$ & & & (mbsf) & (mcd) \\
\hline $306-$ & & & & $306-$ & & \\
\hline 1313B-1H-3, 128 & 4.28 & 4.45 & Tie to & $1313 \mathrm{C}-2 \mathrm{H}-1,132$ & 4.02 & 4.45 \\
\hline $1313 \mathrm{C}-2 \mathrm{H}-6,142$ & 11.62 & 12.05 & Tie to & 1313B-2H-3, 138.5 & 10.29 & 12.05 \\
\hline 1313B-2H-6, 130 & 14.70 & 16.46 & Tie to & $1313 \mathrm{C}-3 \mathrm{H}-2,132$ & 15.02 & 16.46 \\
\hline $1313 \mathrm{C}-3 \mathrm{H}-6,56$ & 20.26 & 21.70 & Tie to & $1313 \mathrm{~B}-3 \mathrm{H}-3,60$ & 19.00 & 21.70 \\
\hline 1313B-3H-6, 68 & 23.58 & 26.28 & Tie to & $1313 \mathrm{C}-4 \mathrm{H}-2,28$ & 23.48 & 26.28 \\
\hline $1313 \mathrm{C}-4 \mathrm{H}-5,145$ & 29.15 & 31.95 & Tie to & 1313B-4H-2, 100 & 27.40 & 31.95 \\
\hline 1313B-4H-5, 102.5 & 31.92 & 36.47 & Tie to & $1313 \mathrm{C}-5 \mathrm{H}-1,72.7$ & 31.93 & 36.47 \\
\hline $1313 \mathrm{C}-5 \mathrm{H}-7,82$ & 41.02 & 45.56 & Tie to & 1313B-5H-4, 46 & 39.36 & 45.56 \\
\hline 1313B-5H-6, 58 & 42.48 & 48.68 & Tie to & $1313 \mathrm{C}-6 \mathrm{H}-3,24$ & 43.94 & 48.68 \\
\hline $1313 \mathrm{C}-6 \mathrm{H}-4,120$ & 46.40 & 51.14 & Tie to & $1313 \mathrm{~B}-6 \mathrm{H}-1,88.5$ & 44.79 & 51.14 \\
\hline 1313B-6H-6, 46 & 51.86 & 58.21 & Tie to & 1313C-7H-1, 118 & 51.38 & 58.21 \\
\hline 1313C-7H-6, 64 & 58.34 & 65.17 & Tie to & 1313B-7H-3, 88 & 57.28 & 65.17 \\
\hline 1313B-7H-6, 126 & 62.16 & 70.05 & Tie to & 1313C-8H-2, 52 & 61.72 & 70.05 \\
\hline $1313 \mathrm{C}-8 \mathrm{H}-5,44$ & 66.14 & 74.47 & Tie to & 1313B-8H-2, 44 & 64.84 & 74.47 \\
\hline $1313 \mathrm{~B}-8 \mathrm{H}-4,34$ & 67.74 & 77.37 & Tie to & 1313C-9H-1, 24 & 69.44 & 77.37 \\
\hline $1313 \mathrm{C}-9 \mathrm{H}-6,44$ & 77.14 & 85.07 & Tie to & 1313B-9H-2, 110 & 75.00 & 85.07 \\
\hline 1313B-9H-6, 4 & 79.94 & 90.01 & Tie to & $1313 \mathrm{C}-10 \mathrm{H}-1,130$ & 80.00 & 90.01 \\
\hline $1313 \mathrm{C}-10 \mathrm{H}-5,24$ & 84.94 & 94.95 & Tie to & 1313B-10H-2, 24 & 83.64 & 94.95 \\
\hline 1313B-10H-5, 145 & 89.35 & 100.66 & Tie to & $1313 \mathrm{C}-11 \mathrm{H}-2,5$ & 89.75 & 100.66 \\
\hline $1313 \mathrm{C}-11 \mathrm{H}-5,50$ & 94.70 & 105.61 & Tie to & 1313B-11H-2, 103.5 & 93.94 & 105.61 \\
\hline 1313B-11H-6, 100 & 99.90 & 111.57 & Tie to & $1313 \mathrm{C}-12 \mathrm{H}-2,6.5$ & 99.27 & 111.57 \\
\hline $1313 \mathrm{C}-12 \mathrm{H}-5,56$ & 104.26 & 116.56 & Tie to & 1313B-12H-2, 112 & 103.52 & 116.56 \\
\hline 1313B-12H-6, 124 & 109.64 & 122.68 & Tie to & $1313 \mathrm{C}-13 \mathrm{H}-2,138$ & 110.08 & 122.68 \\
\hline $1313 \mathrm{C}-13 \mathrm{H}-4,36$ & 112.06 & 124.66 & Tie to & 1313B-13H-1, 64.5 & 111.05 & 124.66 \\
\hline 1313B-13H-6, 76 & 118.66 & 132.27 & Tie to & 1313C-14H-2, 20.5 & 118.41 & 132.27 \\
\hline $1313 \mathrm{C}-14 \mathrm{H}-5,120$ & 123.90 & 137.76 & Tie to & 1313B-14H-3, 27 & 123.18 & 137.76 \\
\hline 1313B-14H-5, 100 & 126.90 & 141.48 & Tie to & $1313 \mathrm{C}-15 \mathrm{H}-1,81$ & 127.02 & 141.48 \\
\hline 1313C-15H-5, 130 & 133.50 & 147.96 & Tie to & 1313B-15H-3, 68 & 133.08 & 147.96 \\
\hline 1313B-15H-6, 135 & 138.25 & 153.13 & Tie to & $1313 \mathrm{C}-16 \mathrm{H}-2,65$ & 137.85 & 153.13 \\
\hline 1313C-16H-5, 142 & 143.12 & 158.40 & Tie to & 1313B-16H-3, 32 & 142.22 & 158.40 \\
\hline 1313B-16H-7, 55 & 148.45 & 164.63 & Tie to & 1313C-17H-2, 147 & 148.17 & 164.63 \\
\hline $1313 \mathrm{C}-17 \mathrm{H}-7,20$ & 154.40 & 170.86 & Tie to & 1313B-17H-4, 75 & 153.65 & 170.86 \\
\hline 1313B-17H-7, 65 & 158.05 & 175.26 & Tie to & 1313C-18H-2, 145 & 157.65 & 175.26 \\
\hline $1313 \mathrm{C}-18 \mathrm{H}-5,45$ & 161.15 & 178.76 & Tie to & 1313B-18H-2, 110 & 160.50 & 178.76 \\
\hline 1313B-18H-6, 100 & 166.40 & 184.66 & Tie to & $1313 \mathrm{C}-19 \mathrm{H}-2,42$ & 166.13 & 184.66 \\
\hline $1313 \mathrm{C}-19 \mathrm{H}-5,125$ & 171.45 & 189.98 & Tie to & 1313B-19H-2, 135.5 & 170.27 & 189.98 \\
\hline 1313B-19H-6, 120 & 176.10 & 195.81 & Tie to & $1313 \mathrm{C}-20 \mathrm{H}-2,70$ & 175.90 & 195.81 \\
\hline 1313C-20H-7, 10 & 182.80 & 202.71 & Tie to & $1313 \mathrm{~B}-20 \mathrm{H}-4,57.5$ & 182.00 & 202.71 \\
\hline 1313B-20H-6, 85 & 185.25 & 205.96 & Tie to & $1313 \mathrm{C}-21 \mathrm{H}-2,95$ & 185.65 & 205.96 \\
\hline $1313 \mathrm{C}-21 \mathrm{H}-6,140$ & 192.10 & 212.41 & Tie to & 1313B-21H-2, 15.5 & 190.07 & 212.41 \\
\hline 1313B-21H-7, 10 & 197.50 & 219.84 & Tie to & $1313 \mathrm{C}-22 \mathrm{H}-4,140$ & 198.60 & 219.84 \\
\hline $1313 \mathrm{C}-22 \mathrm{H}-6,50$ & 200.70 & 221.94 & Tie to & 1313B-22H-2, 15 & 199.55 & 221.94 \\
\hline 1313B-22H-5, 50 & 204.40 & 226.79 & Tie to & $1313 \mathrm{C}-23 \mathrm{H}-2,105$ & 204.75 & 226.79 \\
\hline $1313 \mathrm{C}-23 \mathrm{H}-6,70$ & 210.40 & 232.44 & Tie to & 1313B-23H-1, 150 & 208.90 & 232.44 \\
\hline 1313B-23H-7, 35 & 216.75 & 240.29 & Tie to & $1313 \mathrm{C}-24 \mathrm{H}-5,35$ & 218.05 & 240.29 \\
\hline 1313C-24H-6, 105 & 220.25 & 242.49 & Tie to & $1313 \mathrm{~B}-24 \mathrm{H}-2,20$ & 217.46 & 242.49 \\
\hline 1313B-24H-6, 45 & 223.71 & 248.74 & Tie to & $1313 \mathrm{C}-25 \mathrm{H}-3,130$ & 225.50 & 248.74 \\
\hline $1313 \mathrm{C}-25 \mathrm{H}-7,30$ & 230.50 & 253.74 & Tie to & $1313 \mathrm{~B}-25 \mathrm{H}-2,85$ & 228.12 & 253.74 \\
\hline 1313B-25H-6, 65 & 233.92 & 259.54 & Tie to & $1313 \mathrm{C}-26 \mathrm{H}-4,110$ & 236.30 & 259.54 \\
\hline $1313 \mathrm{C}-26 \mathrm{H}-7,90$ & 240.10 & 263.34 & Tie to & 1313B-26H-2, 78.5 & 237.83 & 263.34 \\
\hline 1313B-26H-6, 35 & 242.23 & 267.74 & Tie to & $1313 \mathrm{C}-27 \mathrm{H}-3,130$ & 244.50 & 267.74 \\
\hline $1313 \mathrm{C}-27 \mathrm{H}-6,60$ & 248.30 & 271.54 & Tie to & 1313B-27H-1, 109 & 246.51 & 271.54 \\
\hline 1313B-27H-4, 15 & 250.05 & 275.08 & Tie to & $1313 \mathrm{C}-28 \mathrm{H}-1,130$ & 251.00 & 275.08 \\
\hline $1313 \mathrm{C}-28 \mathrm{H}-7,50$ & 259.20 & 283.28 & Tie to & 1313B-28H-1, 85 & 255.75 & 283.28 \\
\hline $1313 \mathrm{~B}-28 \mathrm{H}-5,60$ & 261.50 & 289.03 & Tie to & 1313C-29H-4, 125 & 264.95 & 289.03 \\
\hline $1313 \mathrm{C}-29 \mathrm{H}-7,55$ & 268.75 & 292.83 & Tie to & 1313B-29H-1, 90 & 265.30 & 292.83 \\
\hline 1313B-29H-7, 52 & 273.92 & 301.45 & & & & \\
\hline
\end{tabular}


Table T27. Secondary splice tie points, Site U1313.

\begin{tabular}{|c|c|c|c|c|c|c|}
\hline \multirow{2}{*}{$\begin{array}{l}\text { Core, section, } \\
\text { interval }(\mathrm{cm})\end{array}$} & \multicolumn{2}{|c|}{ Depth } & & \multirow{2}{*}{$\begin{array}{l}\text { Core, section, } \\
\text { interval }(\mathrm{cm})\end{array}$} & \multicolumn{2}{|c|}{ Depth } \\
\hline & (mbsf) & (mcd) & & & (mbsf) & $(\mathrm{mcd})$ \\
\hline $306-$ & & & & $306-$ & & \\
\hline 1313A-1H-3, 124 & 4.24 & 4.24 & Tie to & 1313D-1H-3, 22 & 3.22 & 4.24 \\
\hline 1313D-1H-6, 44 & 7.94 & 8.96 & Tie to & $1313 \mathrm{~A}-2 \mathrm{H}-3,14.5$ & 8.35 & 8.96 \\
\hline $1313 \mathrm{~A}-2 \mathrm{H}-6,50$ & 13.20 & 13.81 & Tie to & $1313 \mathrm{D}-2 \mathrm{H}-3,12.5$ & 12.63 & 13.81 \\
\hline 1313D-2H-6, 72 & 17.72 & 18.90 & Tie to & $1313 \mathrm{~A}-3 \mathrm{H}-2,116$ & 17.36 & 18.90 \\
\hline 1313A-3H-5, 62 & 21.32 & 22.86 & Tie to & 1313D-3H-1, 126 & 20.26 & 22.86 \\
\hline 1313D-3H-6, 98 & 27.48 & 30.08 & Tie to & $1313 \mathrm{~A}-4 \mathrm{H}-2,62.5$ & 26.33 & 30.08 \\
\hline $1313 \mathrm{~A}-4 \mathrm{H}-7,47.5$ & 33.67 & 37.43 & Tie to & 1313D-4H-4, 1.3 & 33.03 & 37.43 \\
\hline 1313D-4H-6, 86 & 36.86 & 41.26 & Tie to & $1313 \mathrm{~A}-5 \mathrm{H}-2,130.5$ & 36.51 & 41.26 \\
\hline $1313 \mathrm{~A}-5 \mathrm{H}-6,40$ & 41.60 & 46.35 & Tie to & 1313D-5H-2, 110 & 40.60 & 46.35 \\
\hline 1313D-5H-7, 34 & 47.34 & 53.09 & Tie to & $1313 \mathrm{~A}-6 \mathrm{H}-4,48.5$ & 46.87 & 53.09 \\
\hline 1313A-6H-7, 35 & 51.23 & 57.45 & Tie to & 1313D-6H-3, 67 & 51.18 & 57.45 \\
\hline 1313D-6H-6, 134 & 56.34 & 62.61 & Tie to & 1313A-7H-2, 52 & 54.72 & 62.61 \\
\hline 1313A-7H-6, 96 & 61.16 & 69.05 & Tie to & 1313D-7H-3, 114 & 61.14 & 69.05 \\
\hline 1313D-7H-6, 106 & 65.56 & 73.47 & Tie to & 1313A-8H-2, 94 & 64.64 & 73.47 \\
\hline $1313 \mathrm{~A}-8 \mathrm{H}-5,40$ & 68.60 & 77.43 & Tie to & $1313 \mathrm{D}-8 \mathrm{H}-3,34.5$ & 69.85 & 77.43 \\
\hline 1313D-8H-6, 112 & 75.12 & 82.70 & Tie to & $1313 \mathrm{~A}-9 \mathrm{H}-2,6.5$ & 73.27 & 82.70 \\
\hline 1313A-9H-6, 68 & 79.88 & 89.31 & Tie to & 1313D-9H-4, 8 & 80.58 & 89.31 \\
\hline 1313D-9H-6, 120 & 84.70 & 93.43 & Tie to & 1313A-10H-2, 2 & 82.72 & 93.43 \\
\hline 1313A-10H-6, 112 & 89.82 & 100.53 & Tie to & 1313D-10H-4, 48.5 & 90.49 & 100.53 \\
\hline 1313D-10H-7, 46 & 94.96 & 105.00 & Tie to & $1313 \mathrm{~A}-11 \mathrm{H}-2,84$ & 93.04 & 105.00 \\
\hline 1313A-11H-5, 90 & 97.60 & 109.56 & Tie to & 1313D-11H-3, 84 & 98.84 & 109.56 \\
\hline 1313D-11H-7, 36 & 104.36 & 115.08 & Tie to & $1313 \mathrm{~A}-12 \mathrm{H}-2,54$ & 102.24 & 115.08 \\
\hline $1313 \mathrm{~A}-12 \mathrm{H}-7,40$ & 109.60 & 122.44 & Tie to & 1313D-12H-5, 48 & 110.98 & 122.44 \\
\hline 1313D-12H-, 120 & 113.20 & 124.66 & Tie to & $1313 \mathrm{~A}-13 \mathrm{H}-2,70.5$ & 111.91 & 124.66 \\
\hline 1313A-13H-7, 46 & 119.16 & 131.91 & Tie to & 1313D-13H-4, 69 & 119.20 & 131.91 \\
\hline 1313D-13H-6, 122 & 122.72 & 135.43 & Tie to & $1313 \mathrm{~A}-14 \mathrm{H}-2,86.5$ & 121.57 & 135.43 \\
\hline 1313A-14H-6, 140 & 128.10 & 141.96 & Tie to & 1313D-14H-3, 144.5 & 127.95 & 141.96 \\
\hline 1313D-14H-6, 104 & 132.04 & 146.05 & Tie to & $1313 \mathrm{~A}-15 \mathrm{H}-2,118.5$ & 131.39 & 146.05 \\
\hline 1313A-15H-6, 118 & 137.38 & 152.04 & Tie to & 1313D-15H-3, 84.5 & 136.85 & 152.04 \\
\hline 1313D-15H-7, 2 & 142.02 & 157.21 & Tie to & $1313 \mathrm{~A}-16 \mathrm{H}-3,78$ & 141.98 & 157.21 \\
\hline 1313A-16H-6, 24 & 145.94 & 161.17 & Tie to & 1313D-16H-2, 54.5 & 144.55 & 161.17 \\
\hline 1313D-16H-6, 82 & 150.82 & 167.44 & Tie to & $1313 \mathrm{~A}-17 \mathrm{H}-3,12.5$ & 150.83 & 167.44 \\
\hline 1313A-17H-7, 76 & 157.46 & 174.07 & Append to & 1313A-18H-1, 0 & 157.20 & 175.41 \\
\hline 1313A-18H-7, 76 & 166.96 & 185.17 & Append to & 1313A-19H-1, 0 & 166.70 & 185.69 \\
\hline 1313A-19H-7, 82 & 176.52 & 195.51 & Append to & $1313 \mathrm{~A}-20 \mathrm{H}-1,0$ & 176.20 & 196.71 \\
\hline 1313A-20H-7, 84 & 186.04 & 206.55 & Append to & 1313A-21H-1, 0 & 185.70 & 206.41 \\
\hline 1313A-21H-7, 74 & 195.44 & 216.15 & Append to & $1313 \mathrm{~A}-22 \mathrm{H}-1,0$ & 195.20 & 217.22 \\
\hline 1313A-22H-CC, 55 & 204.29 & 226.31 & Append to & 1313A-23H-1, 0 & 204.70 & 228.19 \\
\hline 1313A-23H-6, 102 & 213.22 & 236.71 & Append to & $1313 \mathrm{~A}-24 \mathrm{H}-1,0$ & 214.20 & 237.59 \\
\hline 1313A-24H-7, 78 & 223.98 & 247.37 & & & & \\
\hline
\end{tabular}


Table T28. Disturbed intervals, Holes U1313A, U1313B, U1313C, and U1313D.

\begin{tabular}{|c|c|}
\hline $\begin{array}{l}\text { Core, section, } \\
\text { interval }(\mathrm{cm})\end{array}$ & Type of disturbance \\
\hline \multicolumn{2}{|l|}{ 306-U1313A- } \\
\hline $1 \mathrm{H}-1,100-105$ & Void \\
\hline $2 \mathrm{H}-1,0-20$ & Mildly disturbed \\
\hline $4 \mathrm{H}-1,0-70$ & Soupy \\
\hline $4 \mathrm{H}-1,141-150$ & Disturbed \\
\hline $5 \mathrm{H}-1,0-80$ & Top of core \\
\hline $6 \mathrm{H}-1,0-150$ & Top of core \\
\hline $7 \mathrm{H}-1,0-28$ & Top of core \\
\hline $8 \mathrm{H}-2,80-88$ & Void \\
\hline $10 \mathrm{H}-1,0-25$ & Top of core \\
\hline $11 \mathrm{H}-1,0-10$ & Top of core \\
\hline $13 \mathrm{H}-1,0-40$ & Top of core \\
\hline $14 \mathrm{H}-1,0-25$ & Top of core \\
\hline $20 \mathrm{H}-1,0-30$ & Top of core \\
\hline $22 \mathrm{H}-1,0-50$ & Top of core \\
\hline $23 \mathrm{H}-1,0-20$ & Top of core \\
\hline $26 \mathrm{H}-1,0-25$ & Top of core \\
\hline $28 \mathrm{H}-1,0-30$ & Top of core \\
\hline $29 \mathrm{H}-1,0-20$ & Top of core \\
\hline $32 \mathrm{H}-1,0-20$ & Top of core \\
\hline $33 \mathrm{H}-3,130-150$ & Mildly disturbed \\
\hline $33 \mathrm{H}-4,0-150$ & Flow-in \\
\hline $33 \mathrm{H}-5,0-150$ & Flow-in \\
\hline $33 \mathrm{H}-6,0-150$ & Flow-in \\
\hline \multicolumn{2}{|l|}{ 306-U1313B- } \\
\hline $1 \mathrm{H}-2,119-125$ & Void \\
\hline $3 \mathrm{H}-1,0-20$ & Top of core \\
\hline $6 \mathrm{H}-1,0-40$ & Top of core \\
\hline $7 \mathrm{H}-1,0-40$ & Top of core \\
\hline $8 \mathrm{H}-1,0-20$ & Top of core \\
\hline $9 \mathrm{H}-1,0-10$ & Top of core \\
\hline $10 \mathrm{H}-1,0-15$ & Top of core \\
\hline $11 \mathrm{H}-1,0-15$ & Top of core \\
\hline $12 \mathrm{H}-1,0-15$ & Top of core \\
\hline $15 \mathrm{H}-1,0-20$ & Top of core \\
\hline $17 \mathrm{H}-1,0-20$ & Top of core \\
\hline $25 \mathrm{H}-1,0-150$ & Top of core \\
\hline $26 \mathrm{H}-1,0-150$ & Top of core \\
\hline $30 \mathrm{H}-1,0-30$ & Top of core \\
\hline $31 \mathrm{H}-1,0-30$ & Top of core \\
\hline $31 \mathrm{H}-1,30-150$ & Mildly disturbed \\
\hline $31 \mathrm{H}-2,0-30$ & Mildly disturbed \\
\hline
\end{tabular}

\begin{tabular}{|c|c|}
\hline $\begin{array}{l}\text { Core, section, } \\
\text { interval }(\mathrm{cm})\end{array}$ & Type of disturbance \\
\hline \multicolumn{2}{|l|}{ 306-U1313C- } \\
\hline $1 \mathrm{H}-1,0-30$ & Top of core \\
\hline $2 \mathrm{H}-1,0-20$ & Top of core \\
\hline $3 \mathrm{H}-1,0-20$ & Top of core \\
\hline $4 \mathrm{H}-1,0-20$ & Top of core \\
\hline $5 \mathrm{H}-1,0-30$ & Top of core \\
\hline $6 \mathrm{H}-1,0-30$ & Top of core \\
\hline $6 \mathrm{H}-2,0-30$ & Soupy \\
\hline $7 \mathrm{H}-1,0-15$ & Top of core \\
\hline $8 \mathrm{H}-1,0-20$ & Top of core \\
\hline $9 \mathrm{H}-1,0-20$ & Top of core \\
\hline $10 \mathrm{H}-1,0-5$ & Top of core \\
\hline $18 \mathrm{H}-1,0-30$ & Top of core \\
\hline $20 \mathrm{H}-1,0-10$ & Top of core \\
\hline $21 \mathrm{H}-1,0-150$ & Homogeneous, possible flow-in \\
\hline $21 \mathrm{H}-2,0-150$ & Homogeneous, possible flow-in \\
\hline $21 \mathrm{H}-3,0-150$ & Homogeneous, possible flow-in \\
\hline $23 \mathrm{H}-1,0-10$ & Top of core \\
\hline $24 \mathrm{H}-1,0-10$ & Top of core \\
\hline $25 \mathrm{H}-1,0-20$ & Top of core \\
\hline $26 \mathrm{H}-1,0-20$ & Top of core \\
\hline $27 \mathrm{H}-1,0-10$ & Top of core \\
\hline $28 \mathrm{H}-1,0-10$ & Top of core \\
\hline $29 \mathrm{H}-1,0-10$ & Top of core \\
\hline $31 \mathrm{H}-1,0-65$ & Top of core \\
\hline \multicolumn{2}{|l|}{ 306-U1313D- } \\
\hline $1 \mathrm{H}-1,0-5$ & Top of core \\
\hline $2 \mathrm{H}-1,0-20$ & Top of core \\
\hline $3 \mathrm{H}-1,0-20$ & Top of core \\
\hline $4 \mathrm{H}-1,0-20$ & Top of core \\
\hline $5 \mathrm{H}-1,0-15$ & Top of core \\
\hline $6 \mathrm{H}-1,0-15$ & Top of core \\
\hline $7 \mathrm{H}-1,0-5$ & Top of core \\
\hline $8 \mathrm{H}-1,0-30$ & Top of core \\
\hline $9 \mathrm{H}-1,0-10$ & Top of core \\
\hline $10 \mathrm{H}-1,0-20$ & Top of core \\
\hline $11 \mathrm{H}-1,0-20$ & Top of core \\
\hline $12 \mathrm{H}-1,0-20$ & Top of core \\
\hline $13 \mathrm{H}-1,0-20$ & Top of core \\
\hline $14 \mathrm{H}-1,0-20$ & Top of core \\
\hline $15 \mathrm{H}-1,0-5$ & Top of core \\
\hline $16 \mathrm{H}-1,0-10$ & Top of core \\
\hline
\end{tabular}

Notes: The top $\sim 20 \mathrm{~cm}$ of all cores should be avoided. When the interval listed is $0-150 \mathrm{~cm}$, the entire section is included even if the true section length is less than $150 \mathrm{~cm}$. 
Table T29. Age model, Site U1313.

\begin{tabular}{rr}
$\begin{array}{r}\text { Depth } \\
\text { (mcd) }\end{array}$ & \multicolumn{1}{c}{$\begin{array}{r}\text { Age } \\
(\mathrm{ka})\end{array}$} \\
\hline 1.24 & 18 \\
3.54 & 62 \\
6.86 & 140 \\
7.40 & 156 \\
8.80 & 188 \\
9.98 & 224 \\
10.82 & 252 \\
12.18 & 270 \\
13.30 & 294 \\
14.86 & 344 \\
19.66 & 434 \\
24.02 & 512 \\
30.64 & 630 \\
34.92 & 718 \\
37.26 & 756 \\
38.50 & 794 \\
42.46 & 876 \\
44.14 & 922 \\
45.74 & 964 \\
46.84 & 988 \\
47.86 & 1004 \\
49.08 & 1038 \\
52.10 & 1098 \\
53.28 & 1126 \\
56.24 & 1198 \\
58.78 & 1248 \\
60.94 & 1290 \\
62.90 & 1336 \\
65.16 & 1372 \\
67.14 & 1412 \\
68.56 & 1456 \\
70.44 & 1496 \\
72.76 & 1540 \\
74.88 & 1576 \\
78.50 & 1628 \\
79.92 & 1654 \\
81.80 & 1706 \\
&
\end{tabular}

\begin{tabular}{rl}
\hline $\begin{array}{l}\text { Depth } \\
(\mathrm{mcd})\end{array}$ & $\begin{array}{l}\text { Age } \\
(\mathrm{ka})\end{array}$ \\
\hline 83.78 & 1748 \\
85.76 & 1794 \\
89.00 & 1860 \\
90.22 & 1900 \\
91.82 & 1948 \\
93.72 & 2004 \\
96.00 & 2046 \\
97.82 & 2072 \\
101.66 & 2152 \\
103.66 & 2200 \\
105.90 & 2240 \\
108.28 & 2282 \\
109.90 & 2320 \\
111.84 & 2358 \\
113.88 & 2404 \\
115.70 & 2436 \\
117.92 & 2488 \\
119.88 & 2522 \\
122.06 & 2566 \\
123.64 & 2600 \\
125.54 & 2646 \\
127.40 & 2688 \\
129.16 & 2716 \\
132.82 & 2806 \\
134.52 & 2848 \\
136.28 & 2886 \\
138.00 & 2926 \\
140.44 & 2978 \\
141.96 & 3018 \\
143.40 & 3050 \\
145.12 & 3090 \\
147.04 & 3136 \\
148.90 & 3176 \\
153.44 & 3296 \\
155.50 & 3340 \\
156.48 & 3380 \\
\hline & \\
\hline
\end{tabular}

Note: Ages according to timescale by Lisiecki and Raymo (2005). 
Table T30. Interstitial water geochemical data, Hole U1313A.

\begin{tabular}{|c|c|c|c|c|c|c|c|c|c|c|c|c|c|c|c|c|c|c|}
\hline \multirow{2}{*}{$\begin{array}{l}\text { Core, section, } \\
\text { interval }(\mathrm{cm})\end{array}$} & \multirow{2}{*}{$\begin{array}{l}\text { Depth } \\
\text { (mbsf) }\end{array}$} & \multirow{2}{*}{$\begin{array}{l}\mathrm{SO}_{4}{ }^{2-} \\
(\mathrm{mM})\end{array}$} & \multirow{2}{*}{$\begin{array}{c}\mathrm{Cl}^{-} \\
(\mathrm{mM})\end{array}$} & \multirow[b]{2}{*}{$\mathrm{pH}$} & \multirow{2}{*}{$\begin{array}{c}\text { Alkalinity } \\
(\mathrm{mM})\end{array}$} & \multirow{2}{*}{$\begin{array}{l}\text { Salinity } \\
(\mathrm{g} / \mathrm{kg})\end{array}$} & \multicolumn{4}{|c|}{ Cations (mM) } & \multicolumn{8}{|c|}{ Trace elements $(\mu \mathrm{M})$} \\
\hline & & & & & & & $\mathrm{Na}^{+}$ & $\mathrm{K}^{+}$ & $\mathrm{Mg}^{2+}$ & $\mathrm{Ca}^{2+}$ & $\mathrm{NH}_{4}^{+}$ & B & $\mathrm{Ba}^{2+}$ & $\mathrm{Fe}^{2+}$ & $\mathrm{Li}^{+}$ & $\mathrm{Mn}^{2+}$ & $\mathrm{H}_{4} \mathrm{SiO}_{4}$ & $\mathrm{Sr}^{2+}$ \\
\hline \multicolumn{19}{|l|}{ 306-U1313A- } \\
\hline $1 \mathrm{H}-2,145-150$ & 3.0 & 26.5 & 568.0 & 7.40 & 3.52 & 33 & 465.3 & 11.4 & 46.8 & 10.1 & 125.8 & 478.1 & 3.2 & 16.2 & 27.4 & 44.8 & 500.1 & 97.6 \\
\hline $2 \mathrm{H}-4,145-150$ & 11.2 & 25.9 & 568.6 & 7.36 & 4.33 & 34 & 477.3 & 11.9 & 46.7 & 9.4 & 229.6 & 495.6 & 3.2 & 5.0 & 24.4 & 34.1 & 470.1 & 133.6 \\
\hline $3 \mathrm{H}-4,145-150$ & 20.7 & 26.8 & 570.9 & 7.20 & 4.96 & 35 & 474.9 & 12.4 & 49.8 & 9.5 & 209.2 & 478.9 & 3.2 & 1.9 & 24.0 & 10.6 & 516.0 & 185.1 \\
\hline $4 \mathrm{H}-4,145-150$ & 30.2 & 26.2 & 559.3 & 7.29 & 5.24 & 34 & 459.1 & 11.3 & 46.1 & 9.2 & 302.0 & 462.5 & 3.2 & 8.8 & 21.5 & 12.8 & 526.6 & 240.5 \\
\hline $5 \mathrm{H}-4,145-150$ & 39.3 & 25.9 & 571.9 & 7.27 & 5.36 & 34 & 493.9 & 12.4 & 46.7 & 10.0 & 281.5 & 509.2 & 3.1 & 6.9 & 20.5 & 5.3 & 562.8 & 291.5 \\
\hline $6 \mathrm{H}-4,145-150$ & 47.8 & 25.5 & 572.9 & 7.35 & 5.50 & 34 & 456.4 & 11.6 & 48.3 & 9.4 & 615.1 & 489.4 & 3.2 & 7.6 & 18.5 & 3.6 & 527.3 & 321.2 \\
\hline $9 \mathrm{H}-4,145-150$ & 77.6 & 25.5 & 571.6 & 7.36 & 6.05 & 34 & 492.1 & 11.6 & 51.8 & 9.4 & 338.2 & 448.3 & 3.2 & 11.2 & 15.0 & 2.4 & 456.1 & 398.0 \\
\hline $12 \mathrm{H}-4,145-150$ & 106.2 & 24.2 & 553.7 & 7.39 & 6.07 & 33 & 417.8 & 10.9 & 46.8 & 8.9 & 418.4 & 451.9 & 3.1 & 11.4 & 12.1 & 3.3 & 450.9 & 534.0 \\
\hline
\end{tabular}


Table T31. Headspace gases, Hole U1313A.

\begin{tabular}{crc}
\hline $\begin{array}{c}\text { Core, section, } \\
\text { interval (cm) }\end{array}$ & $\begin{array}{r}\text { Depth } \\
\text { (mbsf) }\end{array}$ & $\begin{array}{c}\mathrm{C}_{1} \\
\text { (ppmv) }\end{array}$ \\
\hline 306-U1313A- & & \\
1H-3, 0.0-5.0 & 3.00 & 1.9 \\
2H-5, 0.0-5.0 & 11.20 & 1.9 \\
$3 \mathrm{H}-5,0.0-5.0$ & 20.70 & 1.6 \\
$4 \mathrm{H}-5,0.0-5.0$ & 30.20 & 2.4 \\
$5 \mathrm{H}-5,0.0-5.0$ & 39.39 & 1.8 \\
$6 \mathrm{H}-5,0.0-5.0$ & 48.74 & 2.0 \\
$7 \mathrm{H}-5,0.0-5.0$ & 58.70 & 1.9 \\
$8 \mathrm{H}-5,0.0-5.0$ & 68.20 & 1.9 \\
$9 \mathrm{H}-5,0.0-5.0$ & 77.70 & 1.9 \\
$10 \mathrm{H}-5,0.0-5.0$ & 87.20 & 2.2 \\
$11 \mathrm{H}-5,0.0-5.0$ & 96.70 & 2.0 \\
$12 \mathrm{H}-5,0.0-5.0$ & 106.20 & 1.7 \\
$13 \mathrm{H}-5,0.0-5.0$ & 115.70 & 2.1 \\
$14 \mathrm{H}-5,0.0-5.0$ & 125.20 & 1.9 \\
$15 \mathrm{H}-5,0.0-5.0$ & 134.70 & 2.1 \\
$16 \mathrm{H}-5,0.0-5.0$ & 144.20 & 2.0 \\
$17 \mathrm{H}-5,0.0-5.0$ & 153.70 & 1.8 \\
$18 \mathrm{H}-5,0.0-5.0$ & 163.20 & 1.8 \\
$19 \mathrm{H}-5,0.0-5.0$ & 172.70 & 1.7 \\
$20 \mathrm{H}-5,0.0-5.0$ & 182.20 & 1.5 \\
$21 \mathrm{H}-5,0.0-5.0$ & 191.70 & 1.6 \\
$22 \mathrm{H}-5,0.0-5.0$ & 199.67 & 1.8 \\
$23 \mathrm{H}-4,0.0-5.0$ & 209.20 & 1.8 \\
$24 \mathrm{H}-5,0.0-5.0$ & 220.20 & 1.6 \\
$25 \mathrm{H}-5,0.0-5.0$ & 229.70 & 1.8 \\
$26 \mathrm{H}-6,0.0-5.0$ & 239.91 & 1.6 \\
$27 \mathrm{H}-5,0.0-5.0$ & 248.70 & 1.6 \\
$28 \mathrm{H}-5,0.0-5.0$ & 258.20 & 1.7 \\
$30 \mathrm{H}-5,0.0-5.0$ & 277.20 & 1.6 \\
$31 \mathrm{H}-5,0.0-5.0$ & 286.70 & 1.9 \\
$32 \mathrm{H}-5,0.0-5.0$ & 296.20 & 1.9 \\
$33 \mathrm{H}-4,0.0-5.0$ & 304.20 & 1.5 \\
\hline
\end{tabular}

Note: No other gases than $C_{1}$ detected. 
Table T32. Bulk sedimentary C and N, Hole U1313A. (See table note. Continued on next page.)

\begin{tabular}{|c|c|c|c|c|c|c|}
\hline \multirow{2}{*}{$\begin{array}{l}\text { Core, section, } \\
\text { interval }(\mathrm{cm})\end{array}$} & \multirow{2}{*}{$\begin{array}{l}\text { Depth } \\
\text { (mbsf) }\end{array}$} & \multicolumn{4}{|c|}{ Carbon (wt\%) } & \multirow{2}{*}{$\begin{array}{l}\text { Total } \\
\text { nitrogen } \\
\text { (wt\%) }\end{array}$} \\
\hline & & Inorganic & $\mathrm{CaCO}_{3}$ & Total & Organic & \\
\hline \multicolumn{7}{|l|}{ 306-U1313A } \\
\hline $1 \mathrm{H}-1,30-31$ & 0.30 & 6.78 & 56.48 & 6.87 & 0.09 & 0.11 \\
\hline $1 \mathrm{H}-2,145-150$ & 2.95 & 9.09 & 75.72 & 9.41 & 0.32 & 0.16 \\
\hline $1 \mathrm{H}-4,20-21$ & 4.70 & 6.58 & 54.81 & 6.73 & 0.15 & 0.11 \\
\hline $2 \mathrm{H}-1,74-75$ & 5.94 & 5.06 & 42.15 & 5.25 & 0.19 & 0.10 \\
\hline $2 \mathrm{H}-4,145-150$ & 11.15 & 7.67 & 63.89 & 7.79 & 0.12 & 0.17 \\
\hline $2 \mathrm{H}-7,20-21$ & 14.40 & 8.60 & 71.64 & 8.74 & 0.14 & 0.14 \\
\hline $3 \mathrm{H}-3,50-51$ & 18.20 & 4.67 & 38.90 & 4.90 & 0.23 & 0.13 \\
\hline $3 \mathrm{H}-4,145-150$ & 20.65 & 10.05 & 83.72 & 10.10 & 0.05 & 0.15 \\
\hline $3 \mathrm{H}-7,30-31$ & 24.00 & 8.85 & 73.72 & 9.50 & 0.65 & 0.13 \\
\hline $4 \mathrm{H}-1,76-77$ & 24.96 & 7.00 & 58.31 & 7.10 & 0.10 & 0.11 \\
\hline $4 H-4,145-150$ & 30.15 & 10.82 & 90.13 & 10.75 & 0.00 & 0.13 \\
\hline $4 \mathrm{H}-5,60-61$ & 30.80 & 4.60 & 38.32 & 5.17 & 0.57 & 0.13 \\
\hline $5 \mathrm{H}-3,75-76$ & 37.14 & 3.78 & 31.49 & 3.93 & 0.15 & 0.10 \\
\hline $5 H-4,145-150$ & 39.34 & 7.98 & 66.47 & 8.01 & 0.03 & 0.15 \\
\hline $5 \mathrm{H}-6,37-38$ & 41.26 & 8.12 & 67.64 & 8.37 & 0.25 & 0.10 \\
\hline $6 \mathrm{H}-2,80-81$ & 44.35 & 8.52 & 70.97 & 8.56 & 0.04 & 0.11 \\
\hline $6 \mathrm{H}-4,145-150$ & 47.83 & 9.85 & 82.05 & 9.93 & 0.08 & 0.15 \\
\hline $6 \mathrm{H}-6,63-64$ & 50.01 & 7.63 & 63.56 & 7.88 & 0.25 & 0.09 \\
\hline $7 \mathrm{H}-2,76-77$ & 54.96 & 5.06 & 42.15 & 5.05 & 0.00 & 0.10 \\
\hline 7H-6, 119-120 & 61.39 & 8.63 & 71.89 & 8.99 & 0.36 & 0.09 \\
\hline $8 \mathrm{H}-1,110-111$ & 63.30 & 6.12 & 50.98 & 6.16 & 0.04 & 0.11 \\
\hline $8 \mathrm{H}-6,90-91$ & 70.60 & 6.48 & 53.98 & 6.65 & 0.17 & 0.11 \\
\hline $9 \mathrm{H}-1,60-61$ & 72.30 & 6.66 & 55.48 & 6.78 & 0.12 & 0.11 \\
\hline $9 \mathrm{H}-4,145-150$ & 77.65 & 11.19 & 93.21 & 10.99 & 0.00 & 0.14 \\
\hline $9 \mathrm{H}-7,32-33$ & 81.02 & 8.63 & 71.89 & 8.81 & 0.18 & 0.13 \\
\hline $10 \mathrm{H}-2,80-81$ & 83.50 & 8.70 & 72.47 & 8.69 & 0.00 & 0.09 \\
\hline $10 \mathrm{H}-6,65-66$ & 89.35 & 7.35 & 61.23 & 7.41 & 0.06 & 0.10 \\
\hline $11 \mathrm{H}-1,40-41$ & 91.10 & 9.15 & 76.22 & 9.08 & 0.00 & 0.09 \\
\hline $11 \mathrm{H}-6,31-32$ & 98.51 & 8.51 & 70.89 & 8.51 & 0.00 & 0.09 \\
\hline $12 \mathrm{H}-1,90-91$ & 101.10 & 9.48 & 78.97 & 9.51 & 0.03 & 0.08 \\
\hline $12 \mathrm{H}-4,145-150$ & 106.15 & 11.02 & 91.80 & 11.29 & 0.27 & 0.23 \\
\hline $12 \mathrm{H}-5,80-81$ & 107.00 & 6.81 & 56.73 & 6.93 & 0.12 & 0.09 \\
\hline $12 \mathrm{H}-6,100-101$ & 108.70 & 10.13 & 84.38 & 10.15 & 0.02 & 0.11 \\
\hline $13 \mathrm{H}-1,130-131$ & 111.00 & 6.95 & 57.89 & 6.90 & 0.00 & 0.11 \\
\hline $13 \mathrm{H}-6,50-51$ & 117.70 & 8.52 & 70.97 & 8.37 & 0.00 & 0.10 \\
\hline $14 \mathrm{H}-2,68-69$ & 121.38 & 11.21 & 93.38 & 11.24 & 0.03 & 0.13 \\
\hline $14 \mathrm{H}-6,78-79$ & 127.48 & 10.67 & 88.88 & 10.79 & 0.12 & 0.14 \\
\hline $15 \mathrm{H}-3,72-73$ & 132.42 & 10.33 & 86.05 & 10.39 & 0.06 & 0.12 \\
\hline $15 \mathrm{H}-7,38-39$ & 138.08 & 11.11 & 92.55 & 11.26 & 0.15 & 0.09 \\
\hline $16 \mathrm{H}-1,53-54$ & 138.73 & 10.68 & 88.96 & 10.69 & 0.01 & 0.12 \\
\hline $16 \mathrm{H}-5,53-54$ & 144.73 & 11.25 & 93.71 & 11.42 & 0.17 & 0.09 \\
\hline $17 \mathrm{H}-3,73-74$ & 151.43 & 11.30 & 94.13 & 11.40 & 0.10 & 0.08 \\
\hline $17 \mathrm{H}-7,28-29$ & 156.98 & 11.33 & 94.38 & 11.49 & 0.16 & 0.08 \\
\hline $18 \mathrm{H}-3,73-74$ & 160.93 & 11.01 & 91.71 & 11.05 & 0.04 & 0.10 \\
\hline $18 \mathrm{H}-7,28-29$ & 166.48 & 10.78 & 89.80 & 11.11 & 0.33 & 0.10 \\
\hline $19 \mathrm{H}-3,72-73$ & 170.42 & 11.46 & 95.46 & 11.24 & 0.00 & 0.09 \\
\hline $19 \mathrm{H}-7,29-30$ & 175.99 & 11.38 & 94.80 & 11.37 & 0.00 & 0.07 \\
\hline $20 \mathrm{H}-1,50-51$ & 176.70 & 11.30 & 94.13 & 11.17 & 0.00 & 0.09 \\
\hline $20 \mathrm{H}-7,50-51$ & 185.70 & 11.46 & 95.46 & 11.30 & 0.00 & 0.05 \\
\hline $21 \mathrm{H}-2,80-81$ & 188.00 & 11.24 & 93.63 & 11.30 & 0.06 & 0.07 \\
\hline $21 \mathrm{H}-6,80-81$ & 194.00 & 11.23 & 93.55 & 11.23 & 0.00 & 0.07 \\
\hline $22 \mathrm{H}-2,50-51$ & 197.20 & 11.37 & 94.71 & 11.39 & 0.02 & 0.06 \\
\hline $22 \mathrm{H}-7,70-71$ & 203.37 & 11.51 & 95.88 & 11.44 & 0.00 & 0.08 \\
\hline $23 \mathrm{H}-1,40-41$ & 205.10 & 11.61 & 96.71 & 11.42 & 0.00 & 0.07 \\
\hline $23 \mathrm{H}-6,70-72$ & 212.90 & 11.34 & 94.46 & 11.37 & 0.03 & 0.08 \\
\hline $24 \mathrm{H}-2,60-61$ & 216.30 & 11.29 & 94.05 & 11.24 & 0.00 & 0.07 \\
\hline $24 \mathrm{H}-7,27-28$ & 223.47 & 11.26 & 93.80 & 11.11 & 0.00 & 0.08 \\
\hline $25 \mathrm{H}-2,39-40$ & 225.59 & 11.32 & 94.30 & 11.33 & 0.01 & 0.08 \\
\hline $25 \mathrm{H}-7,19-20$ & 232.89 & 11.28 & 93.96 & 11.28 & 0.00 & 0.08 \\
\hline $26 \mathrm{H}-2,50-51$ & 234.95 & 11.28 & 93.96 & 11.30 & 0.02 & 0.07 \\
\hline $26 \mathrm{H}-6,50-51$ & 240.41 & 11.29 & 94.05 & 11.50 & 0.21 & 0.08 \\
\hline $27 \mathrm{H}-1,50-51$ & 243.20 & 11.42 & 95.13 & 11.42 & 0.00 & 0.09 \\
\hline $27 \mathrm{H}-6,50-51$ & 250.70 & 11.11 & 92.55 & 10.91 & 0.00 & 0.09 \\
\hline $28 \mathrm{H}-3,72-73$ & 255.92 & 11.23 & 93.55 & 11.25 & 0.02 & 0.09 \\
\hline $28 \mathrm{H}-7,28-29$ & 261.40 & 11.30 & 94.13 & 11.37 & 0.07 & 0.08 \\
\hline $29 \mathrm{H}-2,68-69$ & 263.88 & 11.33 & 94.38 & 11.39 & 0.06 & 0.08 \\
\hline $29 \mathrm{H}-6,68-69$ & 269.58 & 11.41 & 95.05 & 11.42 & 0.01 & 0.07 \\
\hline
\end{tabular}


Table T32 (continued).

\begin{tabular}{cccccccc}
\hline & & \multicolumn{5}{c}{ Carbon (wt\%) } & Total \\
\cline { 3 - 6 } $\begin{array}{c}\text { Core, section, } \\
\text { interval }(\mathrm{cm})\end{array}$ & $\begin{array}{c}\text { Depth } \\
\text { (mbsf) }\end{array}$ & Inorganic & $\mathrm{CaCO}_{3}$ & Total & Organic & $\begin{array}{c}\text { Nogen } \\
\text { (wt\%) }\end{array}$ \\
\hline $30 \mathrm{H}-3,75-76$ & 274.95 & 11.50 & 95.80 & 11.58 & 0.08 & 0.12 \\
$30 \mathrm{H}-7,18-19$ & 280.38 & 11.21 & 93.38 & 11.24 & 0.03 & 0.10 \\
$31 \mathrm{H}-3,48-49$ & 284.18 & 11.46 & 95.46 & 11.51 & 0.05 & 0.11 \\
$31 \mathrm{H}-7,18-19$ & 289.88 & 11.51 & 95.88 & 11.61 & 0.10 & 0.12 \\
$32 \mathrm{H}-2,55-56$ & 292.25 & 11.16 & 92.96 & & & \\
$32 \mathrm{H}-6,50-51$ & 298.20 & 11.01 & 91.71 & & & \\
$33 \mathrm{H}-2,78-79$ & 301.98 & 11.34 & 94.46 & & & \\
$33 \mathrm{H}-6,78-79$ & 307.98 & 11.52 & 95.96 & & & \\
\hline
\end{tabular}

Note: Italics = values originating from interstitial water squeeze cake samples. 
Table T33. Samples used for organic matter investigations and sea-surface temperature (SST) calculation, Site U1313.

\begin{tabular}{|c|c|c|c|c|c|c|}
\hline \multirow{2}{*}{$\begin{array}{l}\text { Core, section, } \\
\text { interval }(\mathrm{cm})\end{array}$} & \multicolumn{2}{|c|}{ Depth } & \multirow{2}{*}{$\begin{array}{l}\text { Age } \\
(\mathrm{ka})\end{array}$} & \multirow[b]{2}{*}{ CPI } & \multirow[b]{2}{*}{$\mathrm{U}^{\mathrm{k}^{\prime}}{ }_{37}$} & \multirow{2}{*}{$\begin{array}{l}\text { SST } \\
\left({ }^{\circ} \mathrm{C}\right)\end{array}$} \\
\hline & mbsf & mcd & & & & \\
\hline \multicolumn{7}{|l|}{$306-$} \\
\hline U1313A-1H-1, 80-82 & 0.80 & 0.80 & 11.60 & 2.7 & 0.47 & 12.7 \\
\hline U1313A-1H-2, 80-82 & 2.30 & 2.30 & 38.30 & 2.8 & 0.57 & 15.7 \\
\hline U1313A-1H-2, 145-150 & 2.95 & 2.95 & 50.70 & ND & 0.63 & 17.5 \\
\hline U1313A1H3, 80-82 & 3.80 & 3.80 & 146.10 & 2.2 & 0.48 & 12.9 \\
\hline U1313A-2H-4, 145-150 & 11.15 & 11.76 & 264.40 & 3.0 & 0.56 & 15.2 \\
\hline U1313A3H4, 145-150 & 20.65 & 22.19 & 479.30 & 3.0 & 0.53 & 14.5 \\
\hline U1313A4H4, 145-150 & 30.15 & 33.90 & 746.90 & 2.0 & 0.67 & 18.7 \\
\hline U1313B4HCC, 9-14 & 34.74 & 39.29 & 810.36 & ND & 0.48 & 13.1 \\
\hline U1313A-5H-4, 145-150 & 39.65 & 44.40 & 928.80 & 3.2 & 0.49 & 13.3 \\
\hline U1313A-6H-4, 145-150 & 47.83 & 54.05 & 1144.70 & 3.6 & 0.56 & 15.3 \\
\hline U1313B-8H-CC, 22-27 & 72.92 & 82.55 & 1669.90 & 4.7 & 0.66 & 18.1 \\
\hline U1313A-9H-4, 145-150 & 77.65 & 87.08 & 1920.90 & 2.1 & 0.69 & 19.2 \\
\hline U1313A-12H-4, 145-150 & 106.15 & 118.90 & 2505.00 & 2.2 & 0.73 & 20.2 \\
\hline U1313B-12H-CC, 21-26 & 110.81 & 123.85 & 2605.10 & ND & 0.61 & 16.8 \\
\hline U1313A-16H-5, 50-52 & 144.70 & 159.93 & $\sim 3200^{*}$ & 3.0 & 0.77 & 21.6 \\
\hline U1313A-29H-6, 70-72 & 269.60 & 297.93 & $\sim 5800^{*}$ & ND & 0.79 & 22.1 \\
\hline
\end{tabular}

Notes: As the sample set includes also samples from Hole U1313B, depth in mcd is also provided. Given ages are calculated according to Table T29. $\mathrm{CPI}=$ carbon preference index for $n$-alkanes, $\mathrm{Uk}^{\prime}{ }_{37}=\mathrm{C}_{37}$-alkenone unsaturation index, $\mathrm{SST}=$ alkenone-derived sea-surface temperature. See text for details. ${ }^{*}=$ estimated age (according to Fig. F14), ND = not determined. 